OR NL/ NUREG/TM-37

Dist.Category UC-11

Contract No. W-7405-eng-26

CHEMICAL TECHNOLOGY DIVISION

CORRELATION OF RADIOACTIVE WASTE TREATMENT COSTS AND THE ENVIRONMENTAL IMPACT OF WASTE EFFLUENTS IN THE NUCLEAR FUEL

CYCLE - CONVERSION OF RECYCLE URANIUM TO UF 6

\author{
J. W. Roddy \\ R. E. Blanco \\ B. C. Finney \\ G. S. Hill* \\ R. E. Moore* \\ J. P. Witherspoon*
}

Project Manager: R. E. Blanco

Manuscript Completed: April 1977

Date Published: August 1977

*Health and Safety Research Division

\author{
Prepared for the \\ U.S. Nuclear Regulatory Commission \\ Office of Standards Development \\ Under Interagency Agreement ERDA 40-543-75 \\ Prepared by the \\ OAK RIDGE NATIONAL LABORATORY \\ Oak Ridge, Tennessee 37830 \\ operated by \\ UNION CARBIDE CORPORATION \\ for the \\ ENERGY RESEARCH AND DEVELOPMENT ADMINISTRATION

This report was prepared as an account of work sponsored by the United States Government. Neither Research and Development Administration, nor any of their employees, nor any of their contractors, subcontractors, or their employees, makes any warranty, express or implied, or assumes any tegal habily or responsb illy for the accuracy, completenes or userulness of any information, apparatus, product or process disclosed, or represents that its use would not
infringe privately owned rights. 


\section{DISCLAIMER}

This report was prepared as an account of work sponsored by an agency of the United States Government. Neither the United States Government nor any agency Thereof, nor any of their employees, makes any warranty, express or implied, or assumes any legal liability or responsibility for the accuracy, completeness, or usefulness of any information, apparatus, product, or process disclosed, or represents that its use would not infringe privately owned rights. Reference herein to any specific commercial product, process, or service by trade name, trademark, manufacturer, or otherwise does not necessarily constitute or imply its endorsement, recommendation, or favoring by the United States Government or any agency thereof. The views and opinions of authors expressed herein do not necessarily state or reflect those of the United States Government or any agency thereof. 


\section{DISCLAIMER}

Portions of this document may be illegible in electronic image products. Images are produced from the best available original document. 


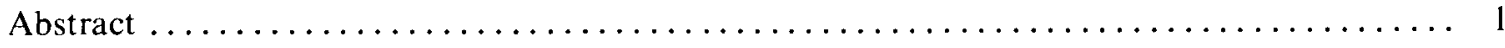

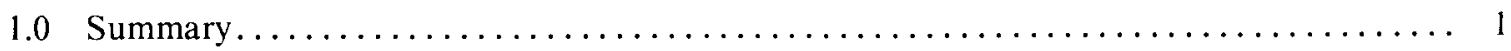

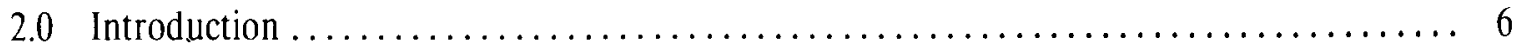

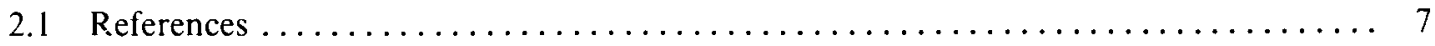

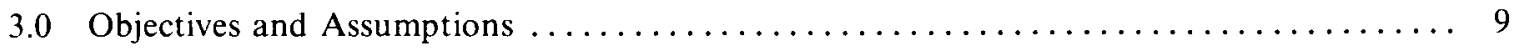

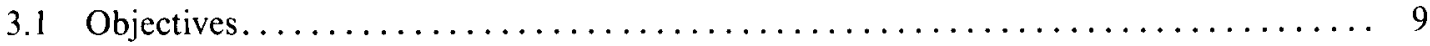

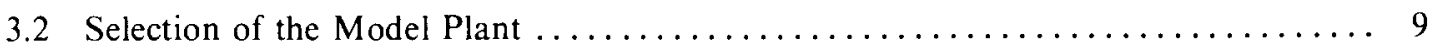

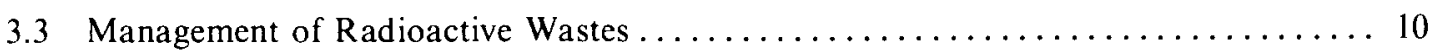

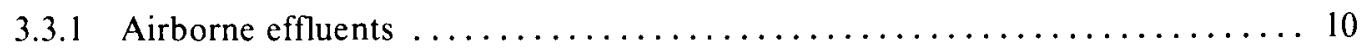

3.3 .2 Liquid effluents....................................... 11

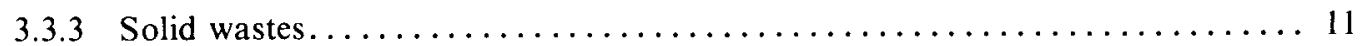

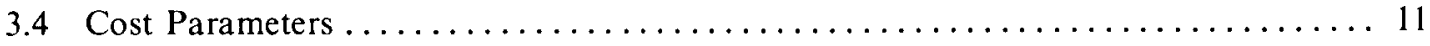

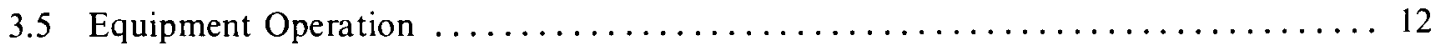

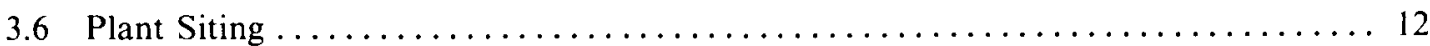

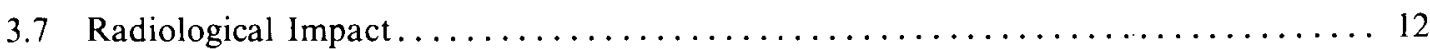

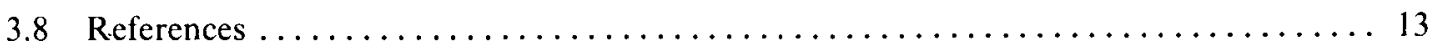

4.0 Source Terms for Radioactive Releases............................. 14

4.1 Origin of the Radioactive Wastes in Recycle Uranium

Hexafluoride Plants...................................... 14

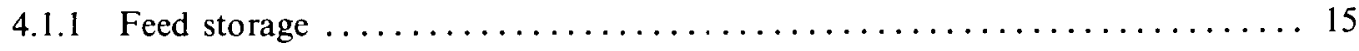

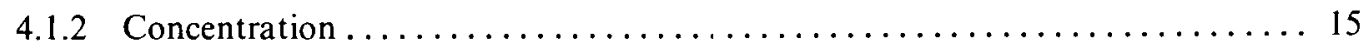

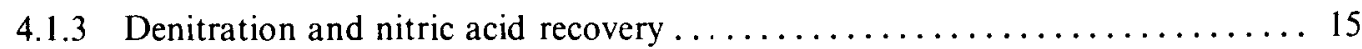

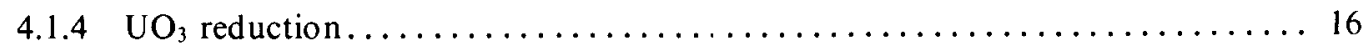

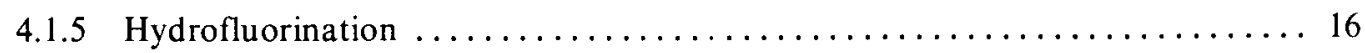

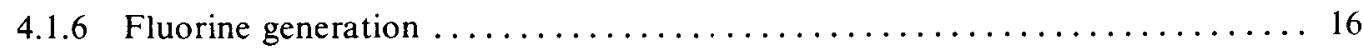

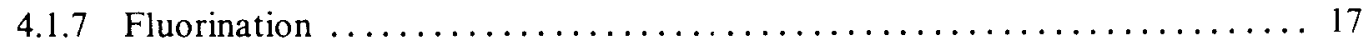

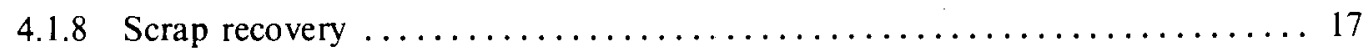

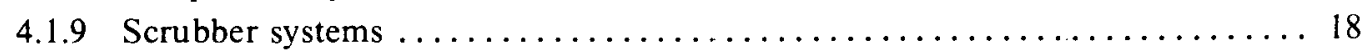

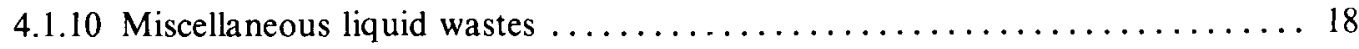

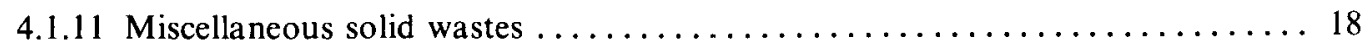

4.1 .12 Process airborne effluent............................... 19

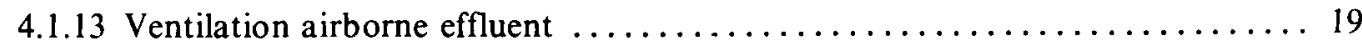

4.2 Composition and Amount of Radioactive Material Entering

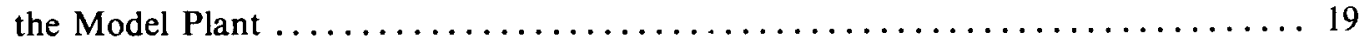

4.3 Description of Waste Treatment Methods .......................... 20

4.3.1 Airborne radioactive waste treatment systems................... 21

4.3.2 Liquid radioactive waste treatment systems.................... 26

4.3.3 Solid radioactive waste treatment methods $\ldots \ldots \ldots \ldots \ldots \ldots \ldots \ldots .28$ 


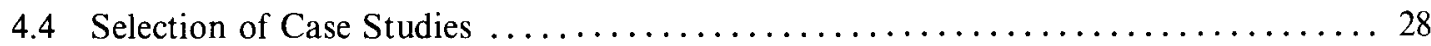

4.5 Description of Case Studies and Calculation of Source Terms ............... 29

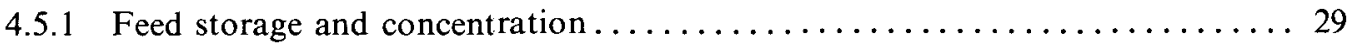

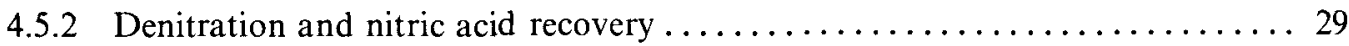

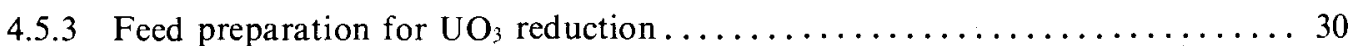

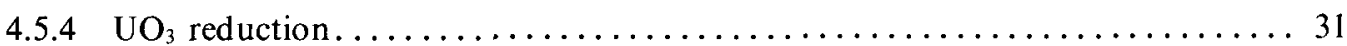

4.5.5 Hydrofluorination of $\mathrm{UO}_{2}$ to $\mathrm{UF}_{4} \ldots \ldots \ldots \ldots \ldots \ldots \ldots \ldots \ldots \ldots \ldots \ldots \ldots \ldots$

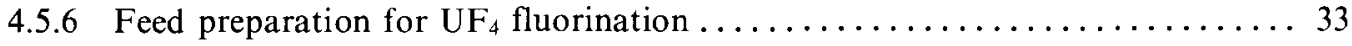

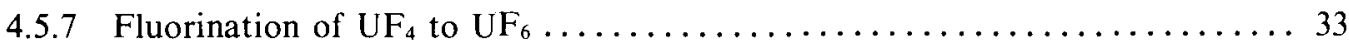

4.5 .8 Fluorine generation and waste treatment $\ldots \ldots \ldots \ldots \ldots \ldots \ldots \ldots \ldots \ldots \ldots$

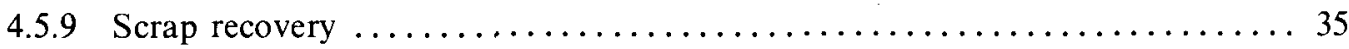

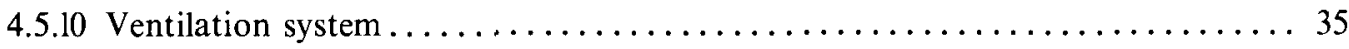

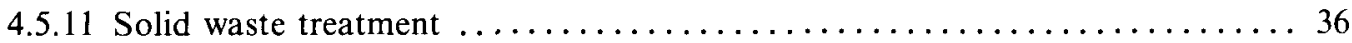

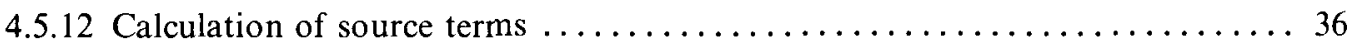

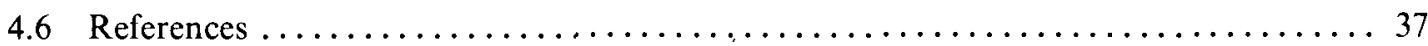

5.0 Nonradioactive Releases...................................... 45

5.1 Airborne Effluents ......................................... 45

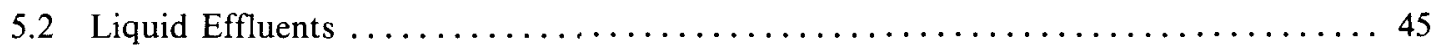

5.3 Thermal Releases ....................................... 45

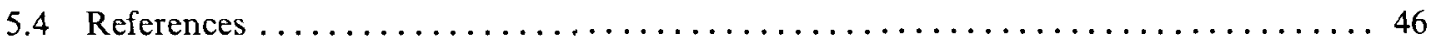

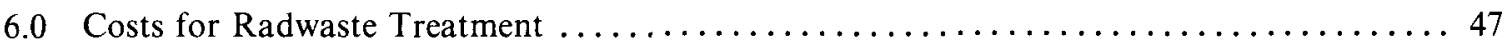

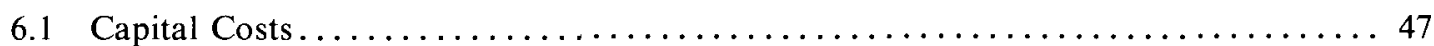

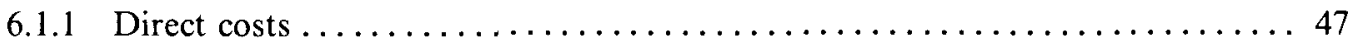

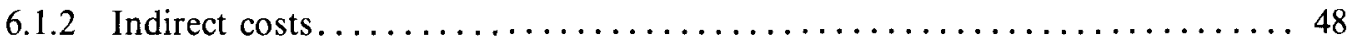

6.2 Annual Fixed Charges and Operating Costs ....................... 48

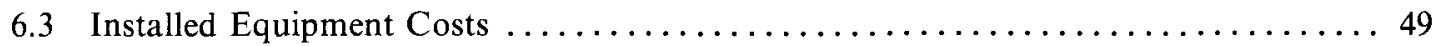

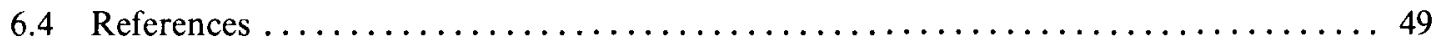

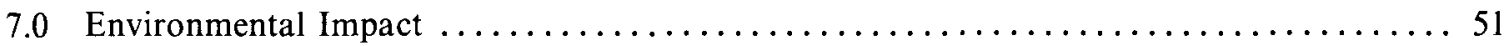

7.1 Radiological Impact of Airborne Effluents During

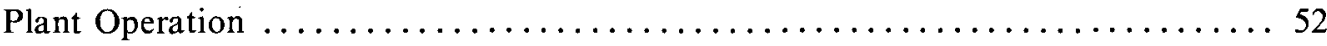

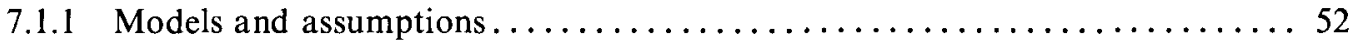

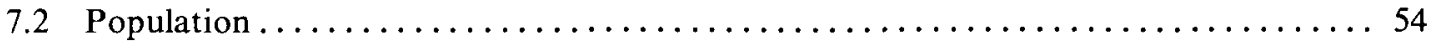

7.3 Environmental Impact of the Recycle $U_{6}$ Plant $\ldots \ldots \ldots \ldots \ldots \ldots \ldots \ldots \ldots \ldots \ldots \ldots \ldots \ldots \ldots \ldots$

7.3.1 Radiation dose commitments from airborne effluents of the

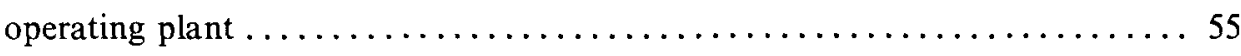

7.3.2 Postoperational exposure from long-lived radionuclides released into the environment from a recycle $U_{6}$ plant $\ldots \ldots \ldots \ldots \ldots \ldots \ldots \ldots$

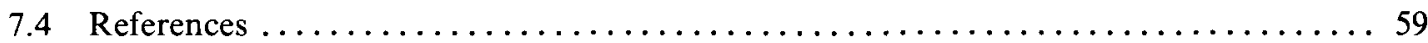


8.0 Correlation of Radiological Dose with Cost of Waste Treatment................ 61

8.1 Comparison of Airborne Radioactive Waste Treatment Costs

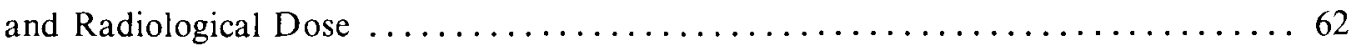

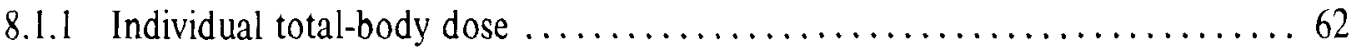

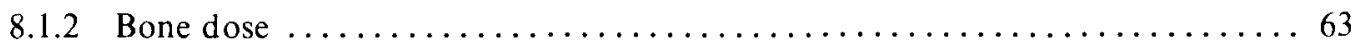

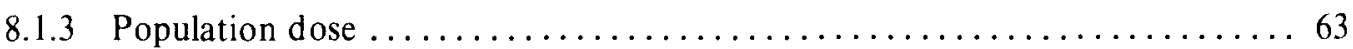

8.1.4 Combined reprocessing-recycle $U_{6}$ facility doses $\ldots \ldots \ldots \ldots \ldots \ldots \ldots 6$

8.2 Comparison of Airborne Radioactive Waste Treatment Costs

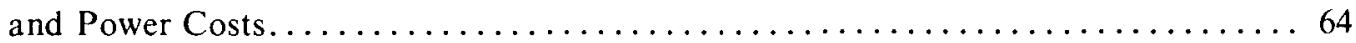

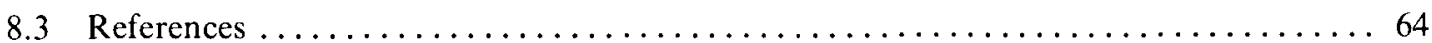

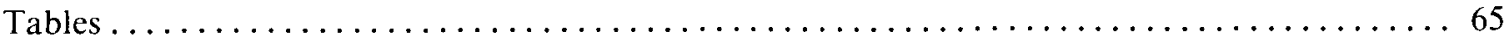

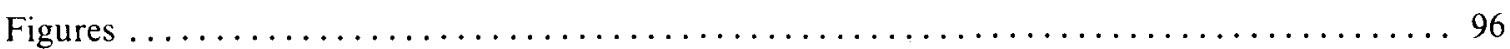

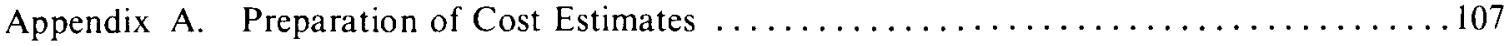




\section{LIST OF TABLES}

Table 1.1 Conceptual waste treatment case studies for the model recycle uranium $-\mathrm{UF}_{6}$ plant $\ldots \ldots \ldots \ldots \ldots \ldots \ldots \ldots \ldots \ldots \ldots \ldots \ldots \ldots \ldots$

Table 1.2 Costs of reducing the total-body dose for the model

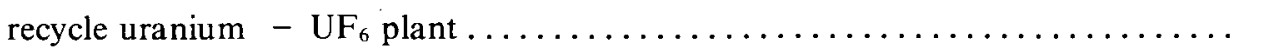

Table 4.1 Material flows for the production of uranium dioxide from recycle uranyl nitrate for the model 1500-metric ton/year recycle uranium $-U_{6}$ plant.

Table 4.2 Material flows for the production of uranium hexafluoride from uranium dioxide for the model 1500-metric ton/year recycle uranium - $\mathrm{UF}_{6}$ plant.

Table 4.3 Fluorine cell waste and recycle streams and material

flows for the model 1500-metric ton/year recycle uranium - $\mathrm{UF}_{6}$ plant

Table 4.4 Material flows for the scrap recovery and solid waste treatment system for the model 1500 -metric ton/year recycle uranium $-U_{6}$ plant...... 68

Table 4.5 Ventilation air flows for the model 1500-metric ton/year recycle uranium - $\mathrm{UF}_{6}$ plant.

Table 4.6 Characteristics of the radioactive materials in the feed to the model 1500-metric ton/year recycle uranium - $U_{6}$ plant.

Table 4.7 Specific activities and relative inhalation hazards of the major radioactive materials in the feed to the model 1500 -metric ton/year recycle uranium - UF 6 plant.

Table 4.8 Airborne radioactive waste treatment variables for the model 1500 -metric ton/year recycle uranium - $\mathrm{UF}_{6}$ plant

Table 4.9 Source terms for the model 1500-metric ton/year recycle uranium - $\mathrm{UF}_{6}$ plant - calculated release of radioactive material in airborne effluents.

Table 6.1 Estimated capital and annual costs and contribution to reprocessing and power costs for the model 1500-metric ton/year recycle uranium - $\mathrm{UF}_{6}$ plant 
Table 6.2 Installed cost of equipment for model 1500-metric ton/year recycle uranium - $U_{6}$ plant radwaste treatment: Cases $2-5 b \ldots \ldots \ldots \ldots \ldots 75$

Table 7.1 Latitude-longitude coordinates used to derive data sets for population distribution .............................. 76

Table 7.2 Representative population distribution at successive

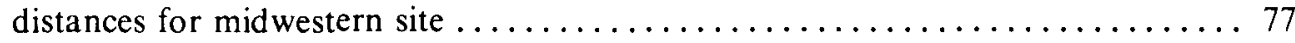

Table 7.3 Representative population distribution at successive

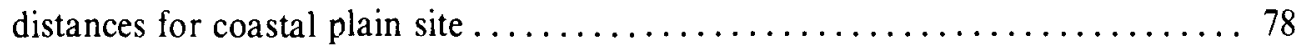

Table 7.4 Maximum dose to individuals from airborne effluents from the model 1500 -metric ton/year recycle uranium - UF 6 plant .

Table 7.5 Summary of annual doses to the population from airborne effluents from the model 1500-metric ton/year recycle uranium - UF 6 plant

Table 7.6 Contribution of exposure modes to total-body dose from the airborne effluents of a model 1500 -metric ton/year recycle uranium $-\mathrm{UF}_{6}$ plant $\ldots \ldots \ldots \ldots \ldots \ldots \ldots \ldots \ldots \ldots \ldots \ldots \ldots \ldots \ldots$

Table 7.7 Contribution of major radionuclides to total-body and organ doses of individuals at 1.5 miles from the model 1500 -metric ton/year recycle uranium - $\mathrm{UF}_{6}$ plant................. 82

Table 7.8 Contribution of major radionuclides to total-body and organ doses of the population out to 55 miles from the model 1500-metric ton/year recycle uranium $-U_{6}$ plant, midwestern site $\ldots \ldots \ldots \ldots \ldots \ldots \ldots \ldots$

Table 7.9 Contribution of major radionuclides to total-body and organ doses of the population out to 55 miles from the model 1500-metric ton/year recycle uranium - UF 6 plant, southeastern coastal site

Table 7.10 Percent of contribution of radionuclides to total-body dose by pathway from the airborne effluents of a model 1500-metric ton/year

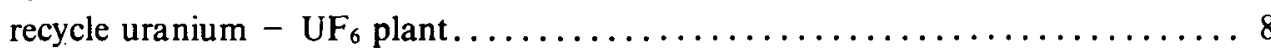

Table 7.11 Percent contribution to organ dose of inhaled and ingested radionuclides from airborne effluents of a model 1500-metric ton/year

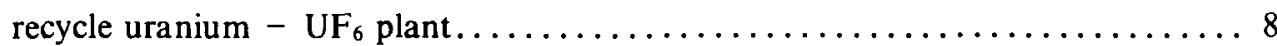


Table 7.12 Curies and concentrations on the ground of long-lived radionuclides released during the 30-year life of the model 1500-metric ton/year

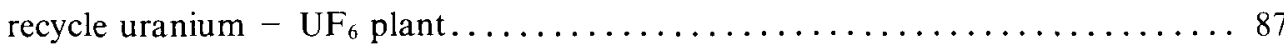

Table 7.13 Contribution of radionuclides and exposure modes from contaminated ground to the annual total-body dose to individuals from the time of cessation of the model 1500-metric ton/year recycle uranium - UF 6 plant operation until significant decay of all radionuclides occurs

Table 7.14 Annual dose to organs of individuals (from long-lived radionuclides deposited on the ground during the operating life of the model 1500-metric ton/year recycle uranium - UF 6 plant) from cessation of plant operation until significant decay of

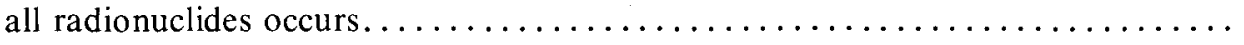

Table 7.15 Annual dose to the population (resulting from long-lived radionuclides deposited on the ground during the lifetime of a model 1500-metric ton/year recycle uranium - $U F_{6}$ plant) from the time of cessation of plant operation until significant decay of all radionuclides occurs...

Table 8.1 Annual cost for reduction of the radiological dose of the model 1500-metric ton/year recycle uranium - $\mathrm{UF}_{6}$ plant.

Table 8.2 Annual cost increments, dose decrements, and cost/benefits between case studies at the model 1500-metric ton/year

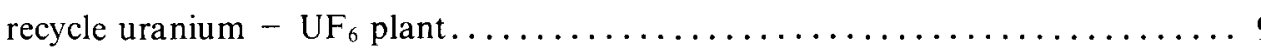

Table 8.3 Annual cost for reduction of dose from airborne effluents at the model 1500-metric ton/year recycle uranium - $\mathrm{UF}_{6}$ plant - dust control system.

Table 8.4 Annual cost for reduction of dose from airborne effluents at the model 1500-metric ton/year recycle uranium - $\mathrm{UF}_{6}$ plant - process off-gas

Table 8.5 Annual cost for reduction of dose from airborne effluents at the model 1500-metric ton/year recycle uranium - UF 6 plant - building ventilation effluent 95

Table A-1 Summary of costs (dollars) for the model recycle uranium $\mathrm{UF}_{6}$ plant - radwaste treatment Cases $2-5 \mathrm{~b}$ 


\title{
CORRELATION OF RADIOACTIVE WASTE TREATMENT COSTS AND THE ENVIRONMENTAL IMPACT OF WASTE EFFLUENTS IN THE NUCLEAR FUEL CYCLE - CONVERSION OF RECYCLE URANIUM TO UF 6
}

\author{
J. W. Roddy, R. E. Blanco, B. C. Finney, G. S. Hill, \\ R. E. Moore, and J. P. Witherspoon
}

\begin{abstract}
A cost/benefit study was made to determine the cost and effectiveness of various radioactive waste (radwaste) treatment systems for decreasing the amount of radioactive materials released from a model recycle uranium conversion and uranium hexafluoride $\left(\mathrm{UF}_{6}\right)$ production plant and to determine the radiological impact (dose commitment) of the released radioactive materials on the environment. This study is designed to assist the U.S. Nuclear Regulatory Commission in defining the term "as low as reasonably achievable" as it applies to these nuclear facilities. The base case model plant is representative of a licensable $\mathrm{UF}_{6}$ production plant and has an annual capacity of 1500 metric tons of uranium. Additional radwaste treatment systems are added to the base case plant in a series of case studies to decrease the amounts of radioactive materials released and to reduce the radiological dose commitment to the population in the surrounding area. The cost for the added waste treatment operations and the corresponding dose commitments is calculated for each case. In the final analysis, radiological dose is plotted vs the annual cost for treatment of the radwastes. The status of the radwaste treatment methods used in the case studies is discussed. The methodology used in estimating the costs is presented in Appendix A.
\end{abstract}

\subsection{SUMMARY}

A study was made to determine the dollar cost and effectiveness of radioactive waste treatment systems for decreasing the amount of radioactive materials released from a model recycle uranium conversion and uranium hexafluoride $\left(\mathrm{UF}_{6}\right)$ production plant and to determine the radiological impact (dose commitment) of the released radioactive materials on the environment. The purpose of the recycle $\mathrm{UF}_{6}$ facility is to convert the purified uranyl nitrate product of a reprocessing plant to $\mathrm{UF}_{6}$ suitable for feed to the enrichment plants. The model $U_{6}$ plant processes 1500 metric tons of uranium per year operating on a 300-day-per-year basis. The plant feed is produced by an adjacent model reprocessing plant. About $5500 \mathrm{Ci}$ of radioactivity enters the plant each year, and about $47 \%$ of this is alpha activity. The feed also contains minute amounts of fission products and transuranium elements which have not been completely removed at the reprocessing plant. It is assumed that the model recycle uranium conversion plant will be sited adjacent to a fuel reprocessing plant and that the boundary of 
the plant is the same for the two units, i.e. at a distance of 1.5 miles (the typical site boundary distance for a reprocessing plant).

The waste treatment systems have been selected: (1) to remove radioactive materials from the airborne effluents, (2) to remove noxious chemicals (fluoride, nitrogen oxides, and sulfur dioxide) from the airborne effluents, (3) to permit the recycle of treated liquid streams, and (4) to provide for the isolation of solid radioactive wastes from the environment. Offsite releases of radioactive materials occur only in the airborne effluents. No liquids containing radioactivity of process origin are discharged from the site during normal operation of the plant.

Five conceptual case studies, each chosen to reflect a decreasing release of radioactivity for an increasing sophistication of radioactive waste treatment, have been selected for the recycle UF $_{6}$ plant. Inclusion of specific treatment techniques was not based on cost, but on the effectiveness in reducing the radioactivity of plant effluents. The general plan and objectives are summarized in Table 1.1. Case 1 is the "base case" and represents a plant which is designed to operate under present licensing regulations. The objectives in Case 2 are to reduce the quantity of dry materials released in the airborne effluent from the dust control system by the addition of secondary bag filters. Case 3 includes additional treatment for the airborne effluents from both the dust control and process off-gas systems. Additional treatment equipment is added to all sections of the effluent system in Case 4 . The Case 5 study is selected to demonstrate the cost of a complete treatment system for the building ventilation effluent (Case 5a) and a method for isolation of solid waste containing radioactivity (Case 5b). All costs are estimated in mid-1973 dollars for the construction of a new plant (Sect. 6.0), and do not include the development costs of the advanced cases. Backfitting of existing plants is not evaluated. The costs are estimated in 1973 dollars so that this survey will be comparable to previous fuel cycle surveys in this series (Sect. 2.1).

The amounts of radioactive materials and chemicals released (Sect. 4.0), the capital, annual, and contribution to power costs (Sect. 6.0), and the radiological impact (the doses, Sect. 7.0) are calculated for each case. The annual cost of treatments which reduce the amount of airborne radioactive materials released is correlated with the maximum annual individual dose commitments (mrem) at 1.5 miles and with the annual population dose commitment out to 55 miles (person-rem, Sect. 8.0). The dose commitments for each case are estimated for total body, bone, lung, kidney, GI tract, thyroid, muscle, liver, spleen, testes, and ovaries (Sect. 7.0). The model plant is assessed at a rural midwestern site and a rural southeastern coastal site. Meteorologic data are derived from nearby first-order weather stations, while the population distribution is taken from census tapes for the region around several fuel reprocessing and fuel fabrication facilities. Realistically conservative assumptions are used in estimating source terms, selecting efficiency ratings for equipment, estimating costs, defining movement of radionuclides in the environment, and selecting food and liquid consumption patterns to be consistent with similar assessments of other segments of the nuclear fuel cycle.

The total annual costs for reduction of the radiological dose commitment to the population surrounding the model recycle $\mathrm{UF}_{6}$ plant are summarized in Table 1.2. The annual costs include annual operating and maintenance costs as well as annual fixed charges for radioactive and chemical waste treatment of airborne and liquid effluents and for packaging solid wastes preparatory to offsite shipment. These costs do not include the expense of onsite storage, shipment, permanent disposal of solid wastes, decommissioning of the plant, or charges 
Table 1.1. Conceptual waste treatment case studies for the model recycle uranium-a $\mathrm{F}_{6}$ plant

\begin{tabular}{|c|c|c|c|c|c|}
\hline & Case 1 & Case 2 & Case 3 & Case 4 & Case 5 \\
\hline $\begin{array}{l}\text { Level of waste } \\
\text { treatment }\end{array}$ & $\begin{array}{l}\text { Meets present } \\
\text { licensing regulations }\end{array}$ & $\begin{array}{l}\text { Similar to recent- } \\
\text { Iy completed plant }\end{array}$ & $\begin{array}{l}\text { Near limits of } \\
\text { present tech- } \\
\text { nology }\end{array}$ & $\begin{array}{l}\text { Uses technolog: } \\
\text { which is not } \\
\text { fully developed }\end{array}$ & $\begin{array}{l}\text { Applies technolog. } \\
\text { to large gas flows }\end{array}$ \\
\hline \multicolumn{6}{|l|}{$\begin{array}{l}\text { Airborne effluent } \\
\text { treatment systems }\end{array}$} \\
\hline Particulates & $\begin{array}{l}\text { Porous metal filter, } \\
\text { centrifugal separa- } \\
\text { tor, bas filter, } \\
\text { HEPA filter }\end{array}$ & $\begin{array}{l}\text { Case } 1 \text { p.lus addi- } \\
\text { tional. bag fi.lter }\end{array}$ & Same as clase? & $\begin{array}{l}\text { Case } 2 \text { plus HF- } \\
\text { resistant HEPA } \\
\text { filter, venturi } \\
\text { scrubber }\end{array}$ & $\begin{array}{l}\text { Case } 4 \text { plus bag rilter } \\
\text { on ventilation system }\end{array}$ \\
\hline \multirow[t]{3}{*}{ Gases } & $\begin{array}{l}\text { Cold traps for } \mathrm{UF}_{\mathrm{O}} \text {, } \\
\text { condenser for } \mathrm{Hb} \\
\text { and } \mathrm{HNO}_{3}\left(\mathrm{NO}_{\mathrm{X}}\right)\end{array}$ & Sane as Case 1 & $\begin{array}{l}\text { Case I plus koH } \\
\text { coke-packed } \\
\text { tower }\end{array}$ & Same as Case 3 & Same as Case 3 \\
\hline & $\begin{array}{l}\text { Burner for } \mathrm{H}_{2} \text { and } \\
\mathrm{H} \mathrm{H}_{\mathrm{S}}\end{array}$ & Same as Case 1 & Same as Case 1 & $\begin{array}{l}\text { Case } 2 \text { plus KOH } \\
\text { venturi scrubber }\end{array}$ & Same as Case 4 \\
\hline & $\begin{array}{l}\text { Serubber systems } \\
\text { for HE and } F_{z}\end{array}$ & Same as Case 7 & $\begin{array}{l}\text { Case l. plus KoH } \\
\text { coke-packed } \\
\text { tower }\end{array}$ & $\begin{array}{l}\text { Case } 3 \text { plus KoH } \\
\text { venturi scrubber }\end{array}$ & Sane as Case ${ }_{4}$ \\
\hline \multicolumn{6}{|l|}{$\begin{array}{l}\text { Liquid effluent } \\
\text { treatment systems }\end{array}$} \\
\hline Nonradioactive & $\begin{array}{l}\text { Monitored and } \\
\text { released }\end{array}$ & Same as Case 1 & Sume as Case 1 & Sane as Case 1 & Same as Case 1 \\
\hline Radioactive & $\begin{array}{l}\text { Concentrated in } \\
\text { evaporators and } \\
\text { treated as solid } \\
\text { radwaste }\end{array}$ & Same as Case 1 & Same as Case 1 & Same as Case 1 & Same as Case 1 \\
\hline \multicolumn{6}{|l|}{ Solid radwaste } \\
\hline treatment systems & $\begin{array}{l}\text { All liquids evap- } \\
\text { orated to dryness, } \\
\text { evaporator bottoms } \\
\text { and other solids } \\
\text { packaged in drums } \\
\text { for disposal }\end{array}$ & Same as Case 1 & Same as Case 1 & Same as Case 1 & $\begin{array}{l}\text { Incorporated in } \\
\text { cement and pack- } \\
\text { aged in drums for } \\
\text { disposal Case 5b) }\end{array}$ \\
\hline
\end{tabular}


Table 1.2. Costs of reducing the total-body dose for the model recycle uranium--UF plant

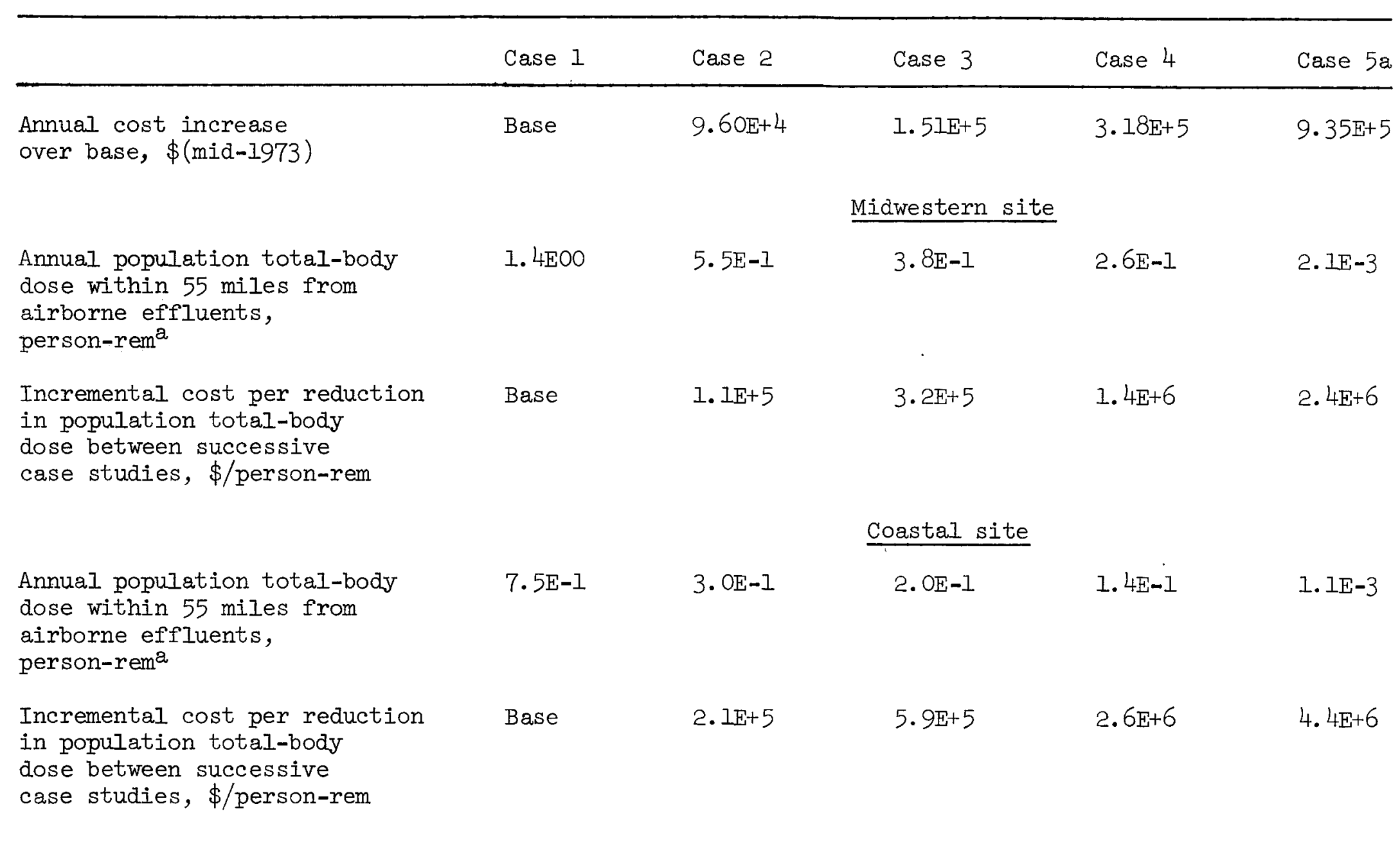

apopulation dose from natural background radiation; midwestern site $-4.6 \mathrm{E}+5$ person-rem, coastal site $-7.2 \mathrm{E}+4$ person-rem. 
for developing advanced treatment methods. The annual cost for Case 2 is $\$ 96,000$ (mid-1973 dollars) more than that for the base case; for Case $5 \mathrm{~b}$, which is the most expensive, it is about $\$ 1.14$ million more than the base case.

The doses to the population out to 55 miles and the cost/benefit ratio are presented in Table 1.2 for the midwestern and the coastal sites. The individual total-body dose from airborne effluents at the midwestern site is reduced from 0.061 to 0.025 millirem from Case 1 to Case 2 and the bone dose from 0.54 to 0.22 millirem. The population total-body dose is reduced from 1.39 to 0.55 person-rem between Cases 1 and 2. The incremental Case 1/Case 2 cost/benefit is $\$ 110,000$ per person-rem total body and $\$ 14,000$ per person-rem bone. Individual and population doses at the coastal site are slightly lower than at the midwestern site due to differences in meteorology and population. Further dose reductions to lower levels are possible, but the incremental cost/benefit is high (i.e., $\$ 1.4$ million per person-rem total body from Case 3 to 4 and $\$ 2.4$ million per person-rem between Cases 4 and $5 \mathrm{a}$ ). The added cost to incorporate solid wastes containing radioactive material into cement between Cases $5 \mathrm{a}$ and $5 \mathrm{~b}$ is $\$ 205,000$. This treatment does not decrease the dose commitment but does reduce the potential for leaching radioactive materials by natural waters after the waste has been placed in storage. The amount of gaseous HF released in Case 1 is $4.6 \mathrm{~kg} /$ day, but is reduced to $2.8 \mathrm{~kg}$ /day in Case 5 . The major fraction of this release $(2.75 \mathrm{~kg} /$ day $)$ originates from the production of fluorine and is the same for all cases.

The capital cost of the total model plant for the base case is estimated at $\$ 20$ million including the Case 1 off-gas treatment system. The unit conversion cost is estimated at $\$ 4.85$ per $\mathrm{kg}$ of uranium for the base plant. The capital costs for the airborne radioactive waste treatment in advanced cases range from $\$ 0.341$ to $\$ 3.59$ million, or up to about $18 \%$ of the capital cost of the base case. The annual cost increases over the base plant range from $\$ 0.096$ to $\$ 1.14$ million and are equivalent to increased power costs of 0.00026 to $0.0031 \mathrm{mill} / \mathrm{kWhr}$. Thus, the cost of airborne radioactive waste treatment is a small fraction of total capital and power generation costs although the absolute dollar costs are high. 


\subsection{INTRODUCTION}

This study was performed to determine the cost and the effectiveness of additional or alternative radioactive waste treatment systems that could be used at recycle uranium conversion and $\mathrm{UF}_{6}$ production plants to decrease the amount of radioactive materials and chemicals released to the environment. A second objective is to determine the radiological impact (dose commitment) of these releases on the environment. The effectiveness of the alternative treatment systems under consideration is measured by comparing the quantities of radioactive materials released by the various systems and the relative impact of each release on the environment. The amount of radioactive material released in each case is designated "the source term," since these values are used in evaluating the impact of radioactive releases on the environment. The impact on the environment is assessed and compared with the radioactive waste treatment costs as the basis for a cost/benefit analysis.

During operation of a commercial nuclear power plant, a portion of the uranium-235 content is not consumed by fissioning. Fuel elements must be removed from the reactor before the fuel values have been completely consumed, primarily because of fission product buildup. Fission products have a high affinity for the parasitic capture of neutrons which are necessary to sustain the chain fission reaction. In the interest of economic utilization of nuclear fuels and the conservation of valuable resources, the residual uranium and plutonium values contained in the spent fuel elements are recovered at a fuel reprocessing plant. A fraction of the recovered uranium may be used in plutonium-base recycle fuels. However, the fraction that can be used in this way is small. The bulk of the uranium will require reenrichment to about $3 \%$ uranium-235, since spent fuel normally contains less than $1 \%$ uranium-235. This reenrichment is accomplished at a diffusion plant such as those located at Oak Ridge, Tennessee, and Paducah, Kentucky, where the feed material is $U_{6}$. Since the purified uranium product from a reprocessing plant is normally in the form of a uranyl nitrate solution, the uranium must be converted to $\mathrm{UF}_{6}$ to be a suitable feed for the enrichment plants. The purpose of the recycle uranium conversion and $\mathrm{UF}_{6}$ production facility is to convert uranyl nitrate into $\mathrm{UF}_{6}$.

The radioactive materials entering the plant consist of isotopes of uranium and daughter products. In addition, the feed material also contains fission products and transuranium materials which have not been completely separated from the recycle uranium. A small fraction of the radioactive materials and noxious chemicals is suspended in the gaseous waste streams from processing areas as dust or aerosols. Treatment systems are used to minimize the release of these materials in the gaseous effluents from the plant. Liquid process streams are treated to recover nonradioactive materials such as nitric acid and water, and to recycle these materials to the reprocessing plant. No liquids containing radioactivity of process origin are released from the plant. Residues from the treatment of liquid wastes containing radioactivity are solidified. These wastes, along with other solids containing radioactivity, are either prepared for shipment offsite or are impounded in onsite storage bins for later disposal.

A model plant that is typical of current designs for $\mathrm{UF}_{6}$ production plants is used as the base case for this report. Flowsheets that serve to illustrate the waste treatment methods are developed from the best available information, but are not necessarily representative of any one specific plant. The radiological impact of the plant is considered at two typical sites, i.e., the 
model midwestern location and the model southeastern coastal plain. Case 1 serves as the base for the cost/benefit analysis and contains the minimum treatment necessary for economical operation of the process, including treatment for noxious fumes. Increasingly efficient radioactive waste treatment systems are added to the "base" plant, and the annual cost and environmental impact of each case are calculated. It is not feasible to include all possible variations of base plants and radioactive waste treatment systems, but sufficient information is provided in this study to permit the costs and impacts for other radioactive waste treatment systems to be estimated by extrapolation or interpolation from the data provided. The base case study illustrates important features of plants currently being designed. No sizable production operation exists at this time. All of the treatment equipment is presently available. However, some additional development may be required for the design and operation of air control systems and in the construction and maintenance of sealed filter bank enclosures.

This report is one of a series of studies on the nuclear fuel cycle. Other reports in this series are concerned with reprocessing LWR fuels, ${ }^{\prime}$ milling uranium ores, ${ }^{2}$ fabricating LWR fuels containing enriched uranium, ${ }^{3}$ fabricating LWR fuels containing plutonium, ${ }^{4}$ reprocessing HTGR fuels, ${ }^{5}$ fabricating HTGR fuels, ${ }^{6}$ and converting yellow cake to $\mathrm{UF}_{6}{ }^{7}$

\subsection{References}

1. B. C. Finney, R. E. Blanco, R. C. Dahlman, G. S. Hill, F. G. Kitts, R. E. Moore, and J. P. Witherspoon, Correiation of Radioactive Waste Treatment Costs and the Environmental Impact of Waste Effluents in the Nuclear Fuel Cycle-Reprocessing Light-Water Reactor Fuel, ORNL/NUREG/TM-6 (first revision of ORNL/TM-4901) (June 1976).

2. M. B. Sears, R. E. Blanco, R. C. Dahlman, G. S. Hill, A. D. Ryon, and J. P. Witherspoon, Correlation of Radioactive Waste Treatment Costs and the Environmental Impact of Waste Effluents in the Nuclear Fuel Cycle for Use in Establishing "As Low As Practicable" Guides - Milling of Uranium Ores, ORNL-TM-4903, Vols. 1 and 2 (May 1975).

3. W. H. Pechin, R. E. Blanco, R. C. Dahlman, B. C. Finney, R. B. Lindauer, and J. P. Witherspoon, Correlation of Radioactive Waste Treatment Costs and the Environmental Impact of Waste Effluents in the Nuclear Fuel Cycle for Use in Establishing "As Low As Practicable" Guides - Fabrication of Light-Water Reactor Fuel from Enriched Uranium Dioxide, ORNL-TM-4902 (May 1975).

4. W. S. Groenier, R. E. Blanco, R. C. Dahlman, B. C. Finney, A. H. Kibbey, and J. P. Witherspoon, Correlation of Radioactive Waste Treatment Costs and the Environmental Impact of Waste Effluents in the Nuclear Fuel Cycle for Use in Establishing "As Low As Practicable" Guides - Fabrication of Light-Water Reactor Fuels Containing Plutonium, ORNL-TM-4904 (May 1975). 
5. W. Davis, Jr., R. E. Blanco, B. C. Finney, G. S. Hill, R. E. Moore, and J. P. Witherspoon, Correlation of Radioactive Waste Treatment Costs and the Environmental Impact of Waste Effluents in the Nuclear Fuel Cycle - Reprocessing of High-Temperature Gas-Cooled Reactor Fuel Containing U-233 and Thorium, ORNL/NUREG/TM-4 (May 1976).

6. J. W. Roddy, R. E. Blanco, G. S. Hill, R. E. Moore, R. D. Seagren, and J. P. Witherspoon, Correlation of Radioactive Waste Treatment Costs and the Environmental Impact of Waste Effluents in the Nuclear Fuel Cycle - Fabrication of High-Temperature Gas-Cooled Reactor Fuel Containing Uranium-233 and Thorium, ORNL/NUREG/TM-5 (September 1976).

7. M. B. Sears, R. E. Blanco, B. C. Finney, G. S. Hill, R. E. Moore, and J. P. Witherspoon, Correlation of Radioactive Waste Treatment Costs and the Environmental Impact of Waste Effluents in the Nuclear Fuel Cycle-Conversion of Yellow Cake to Uranium Hexafluoride. Part I. The Fluorination-Fractionation Process, ORNL/NUREG/TM-7 (in preparation). 


\subsection{OBJECTIVES AND ASSUMPTIONS}

\subsection{Objectives}

The objectives of this study are to determine: (1) the dollar cost of using advanced. treatment systems to reduce to very low levels the amount of radioactive materials and noxious chemicals released to the environment from a base plant containing the minimum treatment necessary to operate the process and (2) the radiologic environmental impact (dose) of the radioactive effluents released from these conceptual installations. The definition of the incremental value of additional radioactive waste treatment equipment in terms of increased effectiveness is an important part of the basic objective and is emphasized in the study. Generally, these values will not change with the size of the plant. For example, the amount of waste effluent to be treated generally increases with the plant size and, in turn, larger treatment systems are required. However, the fractional amount released is essentially the same for large and small systems. Consequently, a greater amount of radioactive material is released by the larger system when operating on the same type, but larger volume, of radioactive effluent. The incremental and absolute values derived in this study for a single size of conceptual plant can thus be extrapolated to larger or smaller plants. The calculated total amounts of radioactive materials released are also defined, but are less important in this study since they are expected to vary with plant size. The volumes and compositions of radioactive wastes are based on model flowsheets developed from the best available information.

Estimates are made of the average radioactive and nonradioactive releases and the annual cost of waste treatment over the 30-year operating lifetime of the plant. In a similar study for nuclear power reactors, emphasis was placed on maintaining continuous operation of the power plant.' Consequently, the more complex radioactive waste treatment systems contained redundant (parallel) treatment units to ensure continued operation in case one of the units should become inoperable. In the recycle uranium conversion study, less emphasis is placed on continuous operation since the plant could temporarily cease operations in the event that a major radioactive waste treatment unit failed. Only potential releases from normal operations have been considered in this study.

\subsection{Selection of the Model Plant}

The model plant selected for the Case 1 study is similar to a commercial plant being constructed in the southeastern United States. ${ }^{2}$ An artist's conception of this plant is presented in Fig. 3.1. The major structures consist of two buildings, both of standard chemical plant construction. The main building is a multistory structure containing the principal process areas. A second building located near the main process area is used for fluorine generation. The model $U_{6}$ facility is located near a reprocessing facility to eliminate the shipment of uranyl nitrate to a distant conversion plant. The elimination of the shipping requirement saves time, reduces the cost to the nuclear power industry, and lessens the radiological hazards to the public. 
The model plant is selected to have an annual capacity of 1500 metric tons of uranium. The various processes are assumed to operate $24 \mathrm{hr}$ per day for 300 days a year with the exception of the scrap uranium recycle operation, which operates on an intermittent basis. The plant has been designed such that there is sufficient surge capacity to continue operation when one section is down. Costs are amortized over 15 years, although the assessment of long-term environmental impact is based on a 30 -year operating life.

A simplified flow scheme for the conversion of uranyl nitrate to uranium hexafluoride is depicted in Fig. 3.2. The individual process steps are:

(1) receipt of purified uranyl nitrate solution from a reprocessing plant;

(2) concentration of the uranyl nitrate feed solution via evaporation;

(3) conversion of the uranyl nitrate to $\mathrm{UO}_{3}$ by denitration;

(4) hydrogen reduction of $\mathrm{UO}_{3}$ to $\mathrm{UO}_{2}$;

(5) hydrofluorination of $\mathrm{UO}_{2}$ to $\mathrm{UF}_{4}$ using gaseous $\mathrm{HF}$;

(6) fluorination of $U_{F_{4}}$ to $U F_{6}$ using electrolytically generated $F_{2}$;

(7) freezing and then resubliming $\mathrm{UF}_{6}$ in a series of cold traps; and

(8) packaging of the $U_{6}$ product into standard transport cylinders.

All processing steps which involve radioactive materials are performed inside equipment maintained at negative pressures relative to the adjacent areas of the conversion building. The pressure differentials are maintained so that air flows from noncontaminated areas into areas of potentially higher contamination levels, thus limiting the spread of radioactivity. The equipment forms the first level of confinement, while the conversion building forms the second level. Pressure differentials are maintained by automatically controlled zoned ventilation systems. Spare ventilation fans and required controls, which are provided, are connected to independent or installed emergency power systems in the event of loss of normal plant power and to ensure that the required pressure differentials are maintained.

\subsection{Management of Radioactive Wastes}

The most complex flowsheets in this study illustrate very low, but not zero, release of radionuclides in the airborne effluents. No liquid wastes containing radioactivity are released from the plant.

\subsubsection{Airborne effluents}

Airborne effluents from process vessels contain radioactive particles that are produced directly as solids or are formed from aerosols of process solutions that subsequently dry to become solids. These effluents are treated with filters and wet scrubbers to retain increasingly larger fractions of the radioactive particulates, and noxious fumes. The off-gases from the processing steps each receive a separate pretreatment and are discharged through a $50-\mathrm{m}$ stack. Two additional stacks are used for gaseous discharge; one, which is $30 \mathrm{~m} \mathrm{high}$, is used for the general building ventilation system; the second is a special ventilation stack $(40 \mathrm{~m})$ for the fluorination and decontamination areas. 


\subsubsection{Liquid effluents}

Liquid radioactive wastes from process vessels and other miscellaneous liquids from wet scrubbers contain dissolved and suspended compounds of uranium and uranium daughter products, as well as traces of fission products and transuranium elements. Consideration of the chemistry involved indicates that, in most of the process systems, the relative proportion of these materials in the liquid will be the same as in the solids formed in a given operation. An exception occurs in the production and subsequent filtration of gaseous $U_{6} F_{6}$ where less volatile fission product and transuranic fluorides are removed as solids which are concentrated in the solid waste streams. The liquid radioactive wastes are evaporated to dryness, and the residues are stored in drums for final disposal. In the most advanced case study (Case 5b), the residues are incorporated in cement. The concentration of radioactive material in the condensate from the evaporation step is lower by a factor of 10,000 than that of the original wastes. ${ }^{3}$

\subsubsection{Solid wastes}

The principal solid wastes containing significant quantities of radioactive materials are the filter fines generated during fluorination of $\mathrm{UF}_{4}$. Smaller amounts of radioactivity are found in the miscellaneous wastes that are generated in other parts of the plant. The latter consist of rags, clothing, floor sweepings, disposable filters, and filter residues. Combustible wastes are incinerated, and the residual ash constitutes an additional solid waste. Miscellaneous wastes containing uranium are processed in the scrap recovery system to recover uranium. The residue from the scrap recovery system and other miscellaneous wastes are packaged in drums and stored onsite or shipped to a licensed burial ground. In the most advanced case study, the miscellaneous wastes are incorporated in cement. The waste materials could also be incorporated in plasticizers or asphalt instead of cement. However, cement is selected to avoid the possibility of combustion in a fire during storage or shipment and to avoid excessive leaching of the plasticized product in case the drum should fail and solidified waste should be exposed to water. ${ }^{4,5}$ The case studies do not address the cost of final disposal such as shipping and burial of the wastes or of decommissioning of the plant since these costs will vary with the location of the plant.

\subsection{Cost Parameters}

The capital and annual costs are estimated for the waste effluent treatment systems which are added to the base case in a series of case studies. The calculation of these incremental annual costs is a primary objective of the study. They are correlated with the changes in environmental impact for each case study in Sect. 8.0. The estimated costs are based on an amortization period of 15 years, although the operating lifetime of the plant is assumed to be 30 years. The costs are based on conceptual designs for new model plants, and no attempt is 
made to estimate backfitting costs for present plants. The capital cost of the base 1500-metric-ton-per-year $\mathrm{UF}_{6}$ conversion plant is estimated as $\$ 20$ million in 1973 based on an extrapolation from the estimated costs of a proposed plant. ${ }^{2}$ These costs are used in a qualitative comparison with the incremental capital costs of the case studies. Complete details of the cost estimating procedure are listed in Sect. 6.0.

\subsection{Equipment Operation}

All radioactive wastes are to be treated by the radioactive waste treatment equipment; that is, wastes will not bypass treatment systems and be discharged even though the radioactive content is lower than permissible licensing levels. The equipment is adequately sized to ensure high operating flexibility and efficiency factors. For example, if the liquid radioactive waste is not decontaminated to the desired degree in a single evaporation, it may be recycled and reevaporated. This type of design provides extra assurance that radioactive releases will not exceed the calculated design levels.

\subsection{Plant Siting}

The model plant is located at each of two sites which have environments characteristic of contemporary nuclear fuel reprocessing and fuel fabrication facilities. Site 1 is located on a plain in a rural southeastern coastal area adjacent to a continuously flowing stream that empties into an ocean estuary. Cities with moderate populations are located a short distance from the site. Site 2 is located on a plain in a rural midwestern area adjacent to a continuously flowing stream which empties into a large river. Cities with moderate populations and a large city are located within the survey area. Meteorological data for Sites 1 and 2 are derived from first-order weather stations in the coastal southeastern (Wilmington, N. C.) and midwestern (St. Louis, Mo.) areas of the United States. The population distribution for the sites is determined by averaging the distributions around several nuclear installations in the southeastern and midwestern areas. Site selection is described in detail in Sect. 7.0.

\subsection{Radiological Impact}

The AIRDOS $^{6}$ computer code is used to estimate annual population doses (person-rem) and the maximum annual individual doses in an area surrounding the model fuel cycle plants. Pathways both for external radiation dose from sources outside the body and for internal dose from sources within the body are considered. Immersion in the airborne effluents as they are diluted and dispersed leads to external exposure and inhalation causes internal exposure. The deposition of radioactive particulates on the land surface leads to direct external exposure and to internal exposure by the ingestion of food products through various food chains. Similarly, swimming in waters containing radionuclides can lead to external exposure, whereas the harvest of fish or drinking from the waters can lead to internal exposure. In this study, no radioactive materials are released in the liquid effluents. 
The estimated radiation doses to individuals and to the human population are calculated for annular distances out to 55 miles in $22.5^{\prime \prime}$ sectors using the site parameters listed in Sect. 3.6. Doses to individuals are calculated for the total body and individual organs. Population doses (person-rem) are the sum of the total-body doses to all individuals in the population considered. Details of dose models, assumptions, and methodology are given in Sect. 7.0 .

\subsection{References}

1. USAEC-Directorate of Regulatory Standards, Final Environmental Statement Concerning Proposed Rule Making Action: Numerical Guides for Design Objectives and Limiting Conditions for Operation to Meet the Criterion "As Low As Practicable" for Radioactive Material in Light-Water-Cooled Nuclear Power Reactor Effluents, WASH-1258 (July 1973).

2. Allied-Gulf Nuclear Services, Barnwell, S. C., Environmental Report, UF Facility, Barnwell Nuclear Fuel Plant, Docket 70-1327, Rev. (September 1974).

3. H. W. Godbee, Use of Evaporation for the Treatment of Liquids in the Nuclear Industry, ORNL-4790 (September 1973).

4. A. H. Kibbey and H. W. Godbee, A Critical Review of Solid Radioactive Waste Practices at Nuclear Power Plants, OR NL-4924 (March 1974).

5. R. M. Wallace, H. L. Hull, and R. F. Bradley, Solid Form for Savannah River Plant High-Level Wastes, DP-1335 (December 1973).

6. R. E. Moore, The AIRDOS-II Computer Code for Estimating Radiation Dose to Man from Airborne Radionuclides in Areas Surrounding Nuclear Facilities, OR NL-5245 (April 1977). 


\subsection{SOURCE TERMS FOR RADIOACTIVE RELEASES}

\subsection{Origin of the Radioactive Wastes in Recycle Uranium Hexafluoride Plants}

Periodically, the fuel elements of a nuclear power facility must be removed to prevent loss of reactivity in the reactor due to the accumulation of fission product poisons, to prevent or repair irradiation damage to the fuel elements, and to recover new fuel bred from fertile material. Fuel burnup per cycle ranges from a fraction of a percent to about half of the total amount of fissionable and fertile material. Typically, the fuel is replaced after generating about 25,000 to $35,000 \mathrm{MWd}$ of heat per metric ton of contained fuel. Each year, about 32.4 (from a charge of about 33.5) metric tons of heavy metal in spent fuel per $1000 \mathrm{MW}(\mathrm{e})$, on the average, are discharged from typical large light-water-cooled reactors of 500- to 1200-MW(e) rating [1500 to $3600 \mathrm{MW}(\mathrm{t})]$. In this study, both PWRs and $\mathrm{BWRs}$ are assumed to be discharging fuel with average burnups of 33,000 and $27,500 \mathrm{MWd} /$ ton, respectively, to the reprocessing plant. The capacity of the recycle uranium conversion and $\mathrm{UF}_{6}$ production facility is 1500 metric tons of uranium annually, corresponding to the fuel from about 50 power reactors. Because of economic considerations, the residual uranium and plutonium in spent fuel are recovered in a fuel reprocessing plant.

The function of the recycle uranium facility is to convert uranyl nitrate solution into $\mathrm{UF}_{6}$ that can be used as feed for either an enrichment plant or a commercial fuel fabrication plant. The purified uranyl nitrate solution is piped directly from an adjacent reprocessing plant to the $\mathrm{UF}_{6}$ facility. The total storage time is assumed to be 160 days before reprocessing, which permits short-lived nuclides to decay to valuable or less troublesome products and lessens the amount of heat released by fission product decay. An additional 10 days of storage is assumed after reprocessing, but before $U_{6}$ production, to allow for supplementary decay of ${ }^{237} \mathrm{U}$ and other isotopes.

Two commercial plants in the United States produce $\mathrm{UF}_{6}$ - the Allied Chemical Plant at Metropolis, Illinois, ${ }^{1}$ and the Kerr-McGee Plant at Sequoyah, Oklahoma. ${ }^{2}$ However, both of these plants operate with natural uranium only and are not designed or licensed to operate with enriched uranium. Allied-General Nuclear Services ${ }^{3}$ has a $U_{6}$ facility under construction at their reprocessing plant site (Barnwell, South Carolina) that will convert low-enriched uranyl nitrate to $U_{6}$. Nuclear Fuel Services ${ }^{4}$ had applied for a license to construct a similar facility at their West Valley, New York, site (NFS notified the Nuclear Regulatory Commission in September $1976^{5}$ that it has decided to withdraw from nuclear fuel reprocessing and will no longer pursue their application for amendment to their operating license), and Exxon ${ }^{6,7}$ has applied for a license to construct a reprocessing plant and an adjacent ${ }^{-} F_{6}$ conversion plant in eastern Tennessee.

The model $U F_{6}$ conversion plant consists of two buildings of standard chemical plant construction. The main process operations are housed in a multistory structure which is approximately $100 \mathrm{ft}$ wide by $150 \mathrm{ft}$ long by $125 \mathrm{ft}$ high above the foundation. The building is designed such that the initial processing steps occur on the top floor of the structure. This arrangement maximizes the use of gravity transfers between processing steps, and thereby minimizes the use of potentially troublesome mechanical conveyors and facilitates the 
maintenance of the particulate filters. Each level is separated from adjacent levels by solid floors except for equipment and piping penetrations. Fluorine is produced in a smaller building adjacent to the process building. It is a one-story structure with an area of about 7500 square feet ( $50 \mathrm{ft}$ wide by $150 \mathrm{ft}$ long by $35 \mathrm{ft}$ high). The following sections describe the processing steps that produce the radioactive waste effluents. The processing techniques are similar to those used by the ERDA facilities at Paducah, Kentucky, ${ }^{8}$ and Portsmouth, Ohio." The flowsheets for the production of $\mathrm{UF}_{6}$ from uranyl nitrate are shown in Figs. 4.1 and 4.2, and the amounts of material flowing through the processes are listed in Tables 4.1 and 4.2 for all case studies.

\subsubsection{Feed storage}

Uranyl nitrate solution, containing about $350 \mathrm{~g}$ of uranium per liter, is pumped directly to the $U_{6}$ facility from the adjoining reprocessing plant where it has been recovered from spent fuel. The solution is received in an accountability tank where it is measured, sampled, and then transferred to the storage tanks. This storage area represents the first potential source of radioactive discharge since a small intermittent air stream is used to vent the system when the tank is filled or material is transferred.

\subsubsection{Concentration}

The first processing step at the $\mathrm{UF}_{6}$ plant is the concentration via thermosiphon evaporation ${ }^{10,11}$ of the uranyl nitrate solution to uranyl nitrate hexahydrate (UNH) containing about $1300 \mathrm{~g}$ of uranium per liter. This step removes the excess water and some nitric acid. The vapor is condensed, and the resulting water is recycled to the reprocessing plant. The concentrated material has a melting point above $60^{\circ} \mathrm{C}$ and is held above this temperature to prevent solidification and to provide a uniform liquid feed to the subsequent denitrator.

\subsubsection{Denitration and nitric acid recovery: ${ }^{12-20}$}

The $\mathrm{UNH}$ is calcined to uranium trioxide $\left(\mathrm{UO}_{3}\right)$ in a bed of $\mathrm{UO}_{3}$ fluidized by superheated steam at $300^{\circ} \mathrm{C}$ to $430^{\circ} \mathrm{C}\left(570^{\circ} \mathrm{F}\right.$ to $\left.805^{\circ} \mathrm{F}\right)$. A controlled discharge of $\mathrm{UO}_{3}$ is withdrawn from the bed and fed to the next process step. The decomposition produces a superheated vapor containing steam, nitrogen oxide, nitrogen dioxide, nitric acid, and oxygen. This vapor is vented out of the top of the denitrator to a condenser where the nitrate values are recovered as nitric acid and returned to the reprocessing plant. The $\mathrm{UO}_{3}$ powder continuously overflows into a centrally located disposal tube where it flows into a feed hopper on the $\mathrm{UO}_{3}$ pulverizer. The pulverized powder falls to a feed hopper in the reduction area. 


\subsection{4 $\mathrm{UO}_{3}$ reduction ${ }^{21-24}$}

The $\mathrm{UO}_{3}$ product from the denitration step is reduced with dissociated ammonia to $\mathrm{UO}_{2}$ powder in a fluidized-bed reduction system. Uranium trioxide powder is collected in a feed hopper which provides surge storage in the process and is transferred from the hopper into the first-stage reduction reactor via a screw feeder. Fluidization is accomplished in the reactor with a reducing atmosphere consisting of a mixture of hydrogen and nitrogen obtained from dissociation of ammonia plus additional nitrogen gas to achieve a thermal balance. The gases and powder flow from the first stage to a similar second-stage reduction reactor where the powder is fluidized by additional dissociated ammonia. The conversion to $\mathrm{UO}_{2}$ is completed in the second-stage reactor, and the powder is collected in a surge storage hopper. The $\mathrm{UO}_{2}$ powder is fed from the hopper on demand to the hydrofluorination system.

\subsubsection{Hydrofluorination ${ }^{25-24}$}

Uranium dioxide from the fluidized-bed reduction units is screw fed into the first of two fluidized-bed hydrofluorinators where it is contacted with the gas from the second hydrofluorinator. Powder and gas flow together from the first hydrofluorinator to an interstage hopper-filter unit. The partially reacted solids are then fed by means of a screw conveyor to the second fluidizer-bed hydrofluorinator where they are reacted with anhydrous HF. The gas feed to the second hydrofluorinator is generated by vaporizing liquid anhydrous HF in a steam-heated vessel. The vapor flows successively through a steam-heated superheater, which increases the temperature from $55^{\prime \prime} \mathrm{C}$ to $175^{\circ} \mathrm{C}\left(130^{\circ} \mathrm{F}\right.$ to $\left.350^{\circ} \mathrm{F}\right)$, and two electrically heated exchangers, which raise the temperature to $425^{\circ} \mathrm{C}\left(800^{\circ} \mathrm{F}\right)$. The $\mathrm{UF}_{4}$ product is screw fed to a mill-blender system for further size reduction and then directed to the fluorination area.

\subsubsection{Fluorine generation ${ }^{30-34}$}

Fluorine is produced onsite in electrolytic cells similar to units that are used to generate fluorine gas throughout the chemical industry. Gaseous HF is fed to the electrolytic cells containing fused potassium bifluoride from a central vaporizing station. The delivery rate at each cell is controlled separately by electrolyte-level sensing devices. A direct current passing through the electrolyte evolves fluorine at the anodes and hydrogen at the cathodes. The fluorine gas is directed to a porous metal filter to remove trace quantities of airborne eletrolyte material, to a surge tank, and then to the fluorination reactors where it is used to convert $\mathrm{UF}_{4}$ to $\mathrm{UF}_{6}$. The hydrogen generated in the cells is oxidized to form water vapor, then passed through a high-energy venturi scrubber and a packed tower to remove any fluorides prior to its release to the atmosphere. Periodic cell maintenance and cell recharging are performed on a routine basis. Fumes from the cell maintenance area are collected through hoods and subsequently released to the environment. The sludge is collected, neutralized, and buried onsite. The process sequence is shown schematically in Fig. 4.3; the amounts of material flowing through the process are listed in Table 4.3. 


\subsubsection{Fluorination ${ }^{35-41}$}

Two techniques have been considered commercially for the preparation of $\mathrm{UF}_{6}$ from $\mathrm{UF}_{4}$. One of these utilizes a fluidized-bed fluorinator containing fused $\mathrm{CaF}_{2}$ as the bed material. (Allied-General Nuclear Services will use such a system. ${ }^{3}$ ) The other technique incorporates a flame tower reactor that is similar to units used at government-owned gaseous diffusion plants. Although both systems will be discussed, the fluidized-bed fluorinator has been selected as the reference method in this study because it presents greater problems in controlling the environmental impact.

The initial bed material in the reference method is fused $\mathrm{CaF}_{2}$ in the $-40+200$-mesh size range. The $\mathrm{UF}_{4}$ feed solids are charged by means of a screw conveyor through the side of the reactor wall at a point slightly above the surface of the bed. Fluorine enters the reactor through a conical inlet section equipped with a ball check valve to prevent backflow of solids. A small amount of $\mathrm{CaF}_{2}$ is added continuously with the $\mathrm{UF}_{4}$ feed to replace ejected material and also to help purge fluorination residues. The effluent gas is removed from the reactor through a large conical settling chamber to minimize powder entrainment to the $\mathrm{UF}_{6}$ recovery system. The process off-gases contain $U_{6}$, excess $F_{2}, H F$, nitrogen, and particulates. The gases are filtered through sintered porous metal filters and directed to a refrigerated cold trap system where the bulk of the $\mathrm{UF}_{6}$ is condensed in a primary cold trap. The secondary and tertiary traps operate at lower temperatures and remove additional UF $_{6}$. The product is removed intermittently from the cold traps by melting and is transferred as a liquid into approved $\mathrm{UF}_{6}$ cylinders through surge tanks.

In the flame tower reactor system, $\mathrm{UF}_{4}$ is fed into the tower through a high-speed mixing unit which provides a finely divided powder as feed. From the dispenser, the powder falls by gravity into the top of the tower where it is mixed with preheated $\left(\sim 320^{\circ} \mathrm{C}\right)$ fluorine. The $\mathrm{UF}_{4}$ fluorine reaction is highly exothermic, producing a flame temperature in excess of $1100^{\circ} \mathrm{C}$ $\left(2000^{\circ} \mathrm{F}\right)$. A small percentage $(1$ to $2 \%)$ of the $\mathrm{UF}_{4}$ passes through the reaction zone and is collected at the base of the tower in a small container or ash receiver. Periodically, the ash material is either recycled to the reactor or sent to a scrap recovery system. Vent gases remaining after cold trapping of product $U_{F_{6}}$ are processed through a cleanup reactor containing an excess of $\mathrm{UF}_{4}$ powder to ensure maximum consumption of the excess fluorine gas. The remainder of the system is as described above.

Exxon plans to produce $\mathrm{UF}_{6}$ by the direct fluorination of $\mathrm{UO}_{3}$ in a fluidized bed of $\mathrm{UO}_{3}$ and alumina. ${ }^{7}$ The $\mathrm{UF}_{6}$ product will be collected in conventional $\mathrm{UF}_{6}$ cold traps and purified by trapping fission product fluorides and transuranic fluorides on selective absorbent beds and distilling the product in a fractionating column.

\subsubsection{Scrap recovery}

Most of the uranium feed material will be converted into $U_{6}$ during the first pass through the plant; but small quantities of uranium will be sent to a uranium recovery step prior to returning it to the process (Fig. 4.4). The scrap is dissolved in nitric acid, filtered to remove any insoluble impurities, and transferred to the precipitation system where uranium 
tetroxide is precipitated by adding ammonia ( $\mathrm{pH}$ increased to 3.0) and hydrogen peroxide. In this system, the principal objective is to recover the uranium rather than achieve a high degree of separation from impurities since few impurities are present in the scrap. Consequently, the reaction is performed at a relatively high $\mathrm{pH}$ where precipitation is more complete for the uranium. The uranium tetroxide is separated from the mother liquor in centrifuges and

clarifiers. The precipitate is calcined and returned to the reduction feed process step. The quantities of materials flowing through the process are listed in Table 4.4.

\subsubsection{Scrubber systems}

Scrubber systems are an integral part of a $\mathrm{UF}_{6}$ production facility and are used to remove both chemical and radioactive material from the process off-gas stream. The resulting liquids, containing uranium and uranium daughter products, are transferred to a recovery system to regenerate potassium hydroxide, which is then recycled to the scrubber system.

\subsubsection{Miscellaneous liquid wastes}

Miscellaneous liquid wastes are generated by the laundering of clothing, personnel showers, floor drains, laboratory drains, etc. Since all processing operations are carried out in reactor vessels, this liquid waste is normally free of radioactive contamination. The potential for contamination exists, however; thus a miscellaneous liquid waste treatment system exists to monitor and treat this waste (Fig. 4.5). When radioactivity is detected in this stream, the liquid is piped to a holding basin and then transferred to a reverse osmosis unit and the permeate is sent to an evaporator where the water is removed and discharged through a stack and the bottoms are stored in drums for disposal.

\subsubsection{Miscellaneous solid wastes}

Miscellaneous solid wastes, including gloves, cleaning materials, filters, etc., are separated into combustible and noncombustible materials. An incinerator is used to reduce combustible wastes to a residue which is packaged into drums for disposal. Radioactive materials in the incinerator off-gas are retained by a filter system attached to the incinerator unit that is considered to be part of the base plant. Thus, it is common to all of the case studies. Noncombustible wastes are mechanically compacted, where feasible, and transferred to the solid radioactive waste treatment system for packaging. Fluorides collected in the scrubber solution are converted to insoluble $\mathrm{CaF}_{2}$, separated from the scrubber solution, and placed in drums for disposal. 


\subsubsection{Process airborne effluent}

The processing units in the $U_{6}$ production and waste treatment systems are connected to the process airborne effluent treatment system. These combined effluents contain small quantities of radioactive and nonradioactive materials, including gases that are produced in the various operations and are not removed by the scrubbers. Aerosols of solutions which dry to particulates represent a complete spectrum of the radioactive and nonradioactive materials in the process liquids. Additional particles are derived from drying and calcining operations, and from ventilation of laboratory hoods and other special areas by resuspension of settled particles. These airborne effluents are combined and discharged through a separate $50-\mathrm{m}$ stack. The process gaseous flow rate is $\sim 368 \mathrm{std} \mathrm{m}^{3} / \mathrm{min}$ (scmm) $(\sim 13,000 \mathrm{scfm})$.

\subsubsection{Ventilation airborne effluent}

The air from the operating areas contains small amounts of radioactive particulates of uranium, transuranics, and fission products. The suspension of these particles occurs during such operations as loading material into a process reactor or transferring material from one process to another, or may result from the leakage and drying of process solutions from pipes or packing glands. Current designs for $\mathrm{UF}_{6}$ production facilities use high ventilation and process air flow rates; hence the ventilation flow rate of the model $U F_{6}$ facility is $5300 \mathrm{scmm}$ $(186,000 \mathrm{scfm})$, which is exhausted through a separate $30-\mathrm{m}$ stack. A separate ventilation stack $(40 \mathrm{~m})$ discharges air from the fluorination and decontamination areas $(425 \mathrm{scmm}$ or $15,000 \mathrm{scfm})$. The quantities of materials flowing through the ventilation system are listed in Table 4.5; a schematic flowsheet of the system is shown in Fig. 4.6.

\subsection{Composition and Amount of Radioactive Material Entering the Model Plant ${ }^{42-47}$}

The model $\mathrm{UF}_{6}$ production plant processes 1500 metric tons of uranium per year in the form of a uranyl nitrate solution produced by an adjacent reprocessing plant. This amount of feed represents about $5500 \mathrm{Ci}$ of radioactivity of which approximately $47 \%$ is alpha activity. A list of the radionuclides considered in this study is given in Table 4.6, and the criteria for the selection of this list are as follows:

1. The feed to the $U_{6}$ plant is directly related to the material received by the reprocessing plant. The feed to the reprocessing plant is assumed to be a composite product from the two different types of model 1000-MW(e) light-water reactors $(60 \%$ from pressurized water reactors with an average burnup of 33,000 MWd/MTHM and $40 \%$ from boiling water reactors with an average burnup of $27,500 \mathrm{MWd} / \mathrm{MTHM}$ ). This material has passed through the model reactors, the reprocessing plant, and the 
enrichment cascades twice. In an enrichment facility utilizing only natural uranium as feed material, the enriched product contains the three naturally occurring isotopes ${ }^{234} \mathrm{U}$, ${ }^{235} \mathrm{U}$, and ${ }^{238} \mathrm{U}$. When spent fuels are reprocessed and the recycled uranium is returned to the diffusion plants as $\mathrm{UF}_{6}$ feed, the minor isotopes, ${ }^{232} \mathrm{U},{ }^{233} \mathrm{U}$, and ${ }^{236} \mathrm{U}$, which are formed in reactors during the process of irradiation, are introduced to the enrichment plant. The concentration of these isotopes in the product will depend on the final ${ }^{235} \mathrm{U}$ concentration. The Minor Uranium Isotope Flowsheet Analyzer computer program ${ }^{42,45}$ calculates minor isotope concentrations in product and waste streams of a matched ${ }^{235} \mathrm{U} /{ }^{238} \mathrm{U}$ abundance ratio cascade, given the minor isotope concentrations of all feed and withdrawal streams. The program also calculates the ratio of virgin uranium to recycle uranium required by the cascades. In the second passage through the cascades, the recycled material is diluted by 5.4 parts of virgin uranium to one part of recycled uranium. A cooling period of 160 days occurs before reprocessing.

2. The feed has aged 10 days since passing through the reprocessing plant. This allows sufficient time for the ${ }^{237} \mathrm{U}$ to decay by approximately $64 \%$, or to about one-third of its initial value.

3. Extremely small amounts of fission products and transuranium elements follow the uranium through the reprocessing plant and are associated with the uranium feed. The amounts present in the feed to the $\mathrm{UF}_{6}$ production facility are based on the calculated average amounts of fission products and transuranic elements in the spent reactor fuel that enters the fuel reprocessing plant and the degree of removal of these materials in the reprocessing 'operation [i.e., the plant decontamination factor (DF)]. The decontamination factor is defined as the ratio of material in the plant feed to that in the uranium product. The following plant DFs are used in this study: $10^{7}$ for $\mathrm{Zr}, \mathrm{Nb}, \mathrm{Ru}$, and $\mathrm{Rh} ; 25$ for $\mathrm{Tc} ; 10^{8}$ for all other fission products, $\mathrm{Am}$, and $\mathrm{Cm} ; 10^{6}$ for $\mathrm{Th}$ and $\mathrm{Pu}$; and 300 for $\mathrm{Np}$.

The relative inhalation hazard for each nuclide is estimated by dividing the curies present in 1 metric ton of feed to the model plant by the Radiation Concentration Guide (Code of Federal Regulations, Title 10, Part 20, Appendix B, Table II, Column I) for that nuclide (Table 4.7). Nuclides whose contribution to the total relative inhalation hazard is $<0.01 \%$ are excluded from consideration when calculating source terms. Radionuclides that are excluded on this basis are examined to ensure that they would not contribute more than $0.01 \%$ of the total-body dose for individuals in the case studies as the result of bioaccumulation in the environment. Table 4.7 also lists the radionuclides selected as constituents of the source terms, along with their specific activities.

\subsection{Description of Waste Treatment Methods}

This section contains a general description of waste treatment methods that have been applied to the model $U_{6}$ facility. DFs are given for each of the systems, where appropriate. 


\subsubsection{Airborne radioactive waste treatment systems}

During normal operation of the $U_{6}$ facility, small amounts of radioactive materials are entrained in the process effluent streams. These particles are generafed by the drying of entrained droplets of process liquids and by the entrainment of fine droplets in the various operations. These effluents are treated using a variety of unit process operations to minimize the release of radioactive or other noxious materials. Volatile, semivolatile, and particulate radioactive materials are removed by dust collectors, filters, and scrubbers. All of these treatment methods are in use or are in the development stage. Each of the case studies represents increasingly efficient treatment systems. The costs for each off-gas treatment system in the advanced case studies have been estimated (see Sect. 6.0). The treatment methods that have been considered for the airborne effluents are described in the following sections.

Dry dust collectors. The recovery of uranium-bearing particulate material from the process off-gas streams is an important part of any waste treatment system. Since the particles have such a diversity of properties, several waste treatment methods have been used.

(a) Centrifugal separators. ${ }^{48-49}$ Centrifugal separators, commonly called cyclones, separate particulate matter from a carrier gas by transforming the velocity of an inlet stream to a descending outer vortex and an ascending inner vortex, both confined within the upper cylinder and lower cone of the cyclone. The rapidly rotating descending vortex holds the heavier dust against the walls of the cyclone by centrifugal force and throws it into the hopper from where it is periodically removed. The ascending inner vortex of cleaned gas, which is fed its entire length by the inner surface of the descending vortex, leaves the cyclone through the vortex finder at the top of the cylinder. Because of its simplicity, reliability, and high efficiency, the cyclone collector has been widely used. A fines educator-type cyclone has been used for the vacuum cleaner and maintenance systems with an assumed overall collection efficiency of $75 \%(D F=4)$.

(b) Bag filters. ${ }^{51-55}$ One of the most versatile collectors for the removal of dry, solid particulate matter from an air or gas stream is the fabric dust collector in which the dust-bearing gas is passed unidirectionally through a fabric filter medium of woven or felted cloth. The medium is usually hung in a vertical position to facilitate the removal of the deposited dust. The mechanisms acting in bag filters are considered to be:

1. Direct interception: If the center of a spherical particle follows faithfully the flow line around a fiber, and the flow line approaches closer to the fiber than the radius of the particle, then particle and fiber touch. This mechanism is obviously more important with larger particles.

2. Diffusion: The bombardment of particles by gas molecules causes them to deviate from the flow lines, thus increasing the chance of capture. Diffusion effects increase with smaller particles and lower velocities.

3. Inertia: Massive particles tend to follow a straight path instead of following the air streamlines around a fiber and, hence, may be captured. The inertial mechanism becomes more important with increasing particle mass and velocity.

4. Electrical effects: Charges on particles and fibers may play a considerable part in gas filtration. Neutral particles penetrate a filter more readily than charged particles of similar size. 
5. Sedimentation: At low gas velocities the terminal velocity of large particles may be sufficient for capture by sedimentation. This mechanism is not, however, of concern in the usual type of bag filter. It is, perhaps, of more importance in granular filters of large volume, for example, sand beds.

6. Sieving action: Once an initial layer of the dust has been built up on the surface of the medium, this, in turn, provides the main means of filtering out further dust with improved efficiency, analogous to cake filtration in the separation of solids from liquids.

The media used are woven fabrics of natural or synthetic fibers. The type of yarn, weave, and final finish is chosen to suit the duty required. The formation of the surface layer is dependent on the fine hairs that protrude from the main fibers. Asbestos fibers have been used to increase the efficiency of filtration, but the practice is not recommended because a considerable health risk is associated with the use of asbestos. The inability to withstand extreme temperatures, corrosive atmospheres, and undue mechanical strain limits the use of bag filters. Other disadvantages include the large size of the filters, the high maintenance requirements due to plugging of the filters by moisture when operating below the dew point, and the cost of bag replacement.

Of the many ways to classify bag filters, the most common is that describing their method of cleaning. Such systems as mechanical shaking, automatic reverse air flow, traveling reverse ring jet, and automatic reverse pulsed jet have found the broadest commercial application. However, the pulsed jet type has proved to be the most reliable in $U F_{6}$ plants, exhibiting long life and relatively low maintenance in contrast to the mechanical problems associated with the reverse ring jet method.

The efficiency of a bag filter increases dramatically as the initial layer of dust builds up on the surface medium. Efficiencies as low as $2 \%$ have been measured on new lightweight plain cloth. However, after deposition of the initial layer, the collection efficiency of an individual bag frequently approaches $100 \%$ for particles down to the submicron size range. However, overall process efficiencies are somewhat lower, due to dust losses during initial layer formation.

Two types of bag filters have been selected for this study. A cleaner bag filter is used to remove the coarse material from the two feed preparation steps and has been assigned an efficiency of $75 \%(D F=4)$. A single pulse jet bag filter or the first one in a series is assumed to have an efficiency of $99.9 \%(\mathrm{DF}=1000)$. The second pulse jet filter in a series is assumed to have an efficiency of $86 \%$ (combined efficiency of $99.986 \%$ and an estimated DF for two filters in series of 7000).

(c) Porous metal filters. ${ }^{56-58}$ Porous metal filters have been used extensively in the nuclear industry for removing airborne particulates from gas streams. The filters are made by first producing a uniform powder by a procedure in which a molten stream of alloy is atomized by high-pressure water jets impinging on it. The jets are located on the periphery of a wheel rotating at high speed. A porous metallic sheet is fabricated by spreading the powder out into a thin layer and passing it through a furnace in a strongly reducing atmosphere at a temperature just below the melting point. The points of contact between particles develop into bridges of a diameter about one-fifth to one-third of the particle diameter, thereby bonding the assembly into a sheet of residual porosity approximately equal to the spaces that initially 
existed between the metal powder particles. Virtually all the pore openings formed in this manner are interconnected, resulting in a high flow capacity. The efficiency of the filters is very high; for example, a 1/8-in.-thick filter with a mean pore size of $10 \mu \mathrm{m}$ will remove $98 \%$ of $0.7-\mu \mathrm{m}$ particles $(\mathrm{DF}=50$ ).

Porous stainless steel filters are used on the reduction off-gas, and either Monel or nickel porous filters are used on the fluorination off-gas to recover uranium in the model plant. The parallel train of filters contains a primary system which is equipped with automatic blowback devices to return trapped material directly to the prisess and a secondary system which removes particulates that have bypassed the primary system.

(d) High-efficiency particulate air (HEPA) filters. HEPA filters have been used for many years in the nuclear industry to remove radioactive particles from air streams. A standard HEPA filter has a 2- by 2 -ft cross section and a depth of $1 \mathrm{ft}$ for an air capacity of about $1000 \mathrm{cfm}$. These filters, which are composed of expendable (single-use) pleated mats of fiberglass paper, are installed in banks to achieve the required system capacity. They are specified to exhibit a minimum efficiency of $99.97 \%$ for $0.3-\mu \mathrm{m}$ particles and a maximum resistance (when clean) of 1.0 in. $\mathrm{H}_{2} \mathrm{O}$ pressure when operated at rated airflow. Tests of filter efficiency are conducted in special facilities which ensure that no significant leakage occurs around the sides of the filter or through other bypasses. An equally tight filter enclosure in a field installation must be constructed to achieve the rated filtration efficiency. The construction of large, tight filter enclosures is a difficult engineering task. Testing of the individual filter banks in place in the enclosure, both before and periodically during the service period, by the dioctyl phthalate (DOP) smoke test is required to ensure that no significant leaks are present in either the filter or the enclosure.

Variables that have been considered in HEPA filter performance analyses include the particle size distribution of the various plutonium aerosols encountered. A recent literature survey, however, does not indicate a gross variation in the range of reported particle size in field operations. ${ }^{59}$

Several tests have been carried out with plutonium aerosols on a small scale in laboratories and on a large scale in field installations. In a detailed survey, Hetland and Russell found large-scale filter systems which produced overall mass removal efficiencies of $10^{7}$ or greater. ${ }^{60}$ One such system at Rocky Flats showed a removal efficiency of $99.999 \%$ across the first two banks of a system of four HEPA filter banks in series, $94 \%$ across the third filter bank, and $83 \%$ across the fourth filter bank. The low efficiency value for the fourth bank was attributed to probable bypassing of gases and was not considered to be a measure of filter medium performance. This system, which is about 15 years old, does not represent the latest design practice for HEPA installations. ${ }^{61-62}$ Ettinger et al. have performed laboratory tests using plutonium aerosols in small installations that are tightly sealed and tested periodically for leaks with DOP. ${ }^{63-65}$ They have observed removal efficiencies of at least $99.97 \%$ for each of three single filter stages in series. AEC Regulatory Guide 3.12 for the design of plutonium ventilation systems indicates that removal efficiencies of $>99.95 \%$ should be obtained for a single bank of HEPA filters if the installation containing the filters is constructed according to the recommended guidelines and is tested for leaks after the filters have been installed. ${ }^{66}$ Consequently, a value of $99.95 \%$ has been used in this study to represent the rated efficiency of each HEPA filter that has been properly installed and tested with DOP. 
Several factors must be considered, however, in predicting the overall installed efficiency of multiple filters in series even though each bank is tested separately in place with DOP and shows an efficiency of 99.95 to $99.99 \%$. First, several tests show that the second and third filters are exposed to much lower concentrations of particles with a size distribution that is strongly biased toward the smaller sizes. ${ }^{64}$ Secondly, filter efficiencies are sensitive to gas flow rate, and possibly all filters in a bank may not experience the same flow rate. Finally, the concentration of particles is different for each stage of filtration, and filter efficiency varies with particle concentration. For these reasons, Burchsted recommends the assignment of lower overall efficiencies to filter systems that use HEPA filters in series until more experimental information is available from large installations. ${ }^{67}$ Consequently, the overall installed filter system DFs selected for use in this study for HEPA filters in series are based on a lower efficiency than the rated DF values. For each case study, this approach will result in costs and doses that are realistically conservative. An efficiency of $99.95 \%$ has been assigned a single bank of HEPA filters which are tested periodically in place with DOP and are monitored for efficiency by observing the pressure drop across the filters. Although the overall rated efficiency for two HEPA filters in series is equivalent to a DF of $4.0 \times 10^{6}$, a conservative value of $4.0 \times 10^{5}$ is used in this study.

(e) HF-resistant HEPA filters. ${ }^{6 x, 69}$ Experimental filter assemblies have been tested at the Rocky Flats Division of Dow Chemical Company in a stream containing an estimated 40 to $100 \mu \mathrm{g}$ of $\mathrm{HF}$ per liter as well as nitric acid and plutonium and were found to exhibit efficiencies approaching $99.9 \%$ with a resistance of about 1.3 in. of $\mathrm{H}_{2} \mathrm{O}$. With additional development, these filters should become available for commercial application. For this study the assumption has been made that a $99.95 \%$ efficient HEPA filter which is resistant to a HF concentration of $\sim 1 \mu \mathrm{g} /$ liter will be achieved.

Gas scrubbing. ${ }^{70,71}$ The term "gas scrubbing" describes the technique of bringing gas into intimate contact with a liquid. Under certain conditions, the liquid is capable of removing polluting material, which may be either particulate or gaseous, from the gas. The mechanisms involved in a particular process may be some or all of the following:

1. Impaction: The collision and absorption of aerosol particles by the liquid droplets.

2. Diffusion: The diffusion of gases and very small aerosol particles through the boundary layers to the liquid droplets, if they are absorbed. This process is of great importance if particles are of diameters less than $0.05 \mu \mathrm{m}$.

3. Condensation: Vapors at temperatures below their dew points condense readily on nuclei, such as aerosol particles, which may thereby be agglomerated.

4. Electrostatic charging: The electrostatic charge required by liquid droplets during their formation could assist aerosol entrainment.

A major advantage of the wet scrubber is the great variety of designs, which allows selection of a collector suitable for almost any collection problem. (Many of them are standard industrial equipment available "off the shelf.") Another advantage is that the temperature and the moisture content of the inlet gas are essentially unlimited. Some of the disadvantages include the disposal of a wet sludge, the high energy cost of the high-efficiency scrubber, the high material cost related to services where there is chemical corrosion, and the potential problems of plugged nozzles, unavailability of scrubbing liquid of sufficient clarity, and the treatment of corrosive scrubbing liquids. A unique disadvantage of the wet scrubber is the 
visible white plume, which is the inherent characteristic of all aqueous scrubber stacks discharging to the atmosphere without downstream gas conditioning.

Most conventional scrubbers, when used in the conventional way, have a limited capability for retaining fine particulates. ${ }^{72}$ This is because most conventional scrubbers depend on some form of inertial collection of particulates as their primary mechanism of capture. Because of this, collection efficiency decreases rapidly as particulate size is decreased to the point where inertial forces become insignificantly small. As a result, the energy input into a scrubber must be increased significantly to improve its ability to collect smaller particulates. The energy can be introduced either in the water cycle or the gas cycle. In most commercial collectors, almost all of the energy is introduced in the gas cycle and can be measured as draft loss in inches of water. Even with large energy inputs, their collection efficiencies for particles in the submicron range are not satisfactory. For example, the orifice- or baffle-type collector is $93 \%$ efficient on 5- $\mu \mathrm{m}$ particles, $75 \%$ on $2-\mu \mathrm{m}$ particles, and only $40 \%$ on $1-\mu \mathrm{m}$ particles. ${ }^{73}$ However, high-energy-demanding scrubbers such as the venturi customarily exhibit efficiencies of $99 \%$ on 2- $\mu \mathrm{m}$ particles.

(a) Spray tower scrubber. ${ }^{7-76}$ The spray tower scrubbers are the most elemental of wet scrubbers. They are empty towers utilizing liquid introduced via a bank of spray nozzles at the top. Gases passing countercurrent to the falling drops are scrubbed clean of particulate matter. These towers may also be used as coolers or as primary cleaners. The spray tower is used at the model plant to scrub the $U F_{6}, H F$, and $F_{2}$ from the fluorination off-gas stream. In this study, the efficiency of the $\mathrm{KOH}$ system is assumed to be $80 \%$ for $\mathrm{UF}_{\mathrm{h}}$ removal and $80 \%$ for $\mathrm{F}_{2}$ and $\mathrm{HF}$ removal by analogy to $\mathrm{UF}_{6}$ and $\mathrm{HCl}$.

(b) Wetted packed tower. ${ }^{76-79}$ The packed tower is a vertical vessel in which various fill material is wetted. Surface area provided by the various packings offers a basis for inducing interaction between the liquid and gas phases. The air or gas enters the bottom of the tower and receives a preliminary washing as the scrubbing liquid drains in an opposing flow from the packed, irrigated bed. This liquid, which is pumped into the top of the tower, flows down over the packed bed. Enroute, it covers the surface areas of the packing with a liquid film that accomplishes the major work of collection. Finally, the airstream passes through a mist eliminator section before it is exhausted. In this study, the $\mathrm{KOH}$ packed tower is assumed to have an efficiency of $99 \%$ for $\mathrm{UF}_{6}$ removal and an efficiency of $99 \%$ for $\mathrm{HF}$ and $\mathrm{F}_{2}$ removal by analogy to $\mathrm{UF}_{6}$ and $\mathrm{HCl}$. Since the packed tower is primarily used as a gas absorption system, it has been assumed that its effect on particulate removal is negligible.

(c) Venturi scrubber..$^{7.3 .51-3.3}$ The venturi's basic construction and principles of operation are noncomplex in nature. Atomization of the scrubbing liquid takes place in the throat of the venturi. Here, the liquid is introduced at relatively low pressure and is shattered into minute droplets by the onrushing gas flow. For coarse particles, efficient collection may be attained with lower velocities and water rates than those needed for the collection of submicron particles. The basic advantages of a venturi scrubber are: relatively small size, high efficiency, no moving parts, and ease of recirculation of liquids containing solids. In this study, efficiencies for the high-energy $\mathrm{KOH}$ venturi scrubber are assumed to be $98 \%$ for $\mathrm{SO}_{2}, 99 \%$ for $\mathrm{HF}$ by analogy to $\mathrm{HCl}$ and $\mathrm{Cl}_{2}$, and $99 \%$ for particulates.

(d) Coke-packed tower. ${ }^{84}$ Activated charcoal and coke have been used extensively to remove pollutants from process streams. Recently, Bergbaw-Forschung, the research institute 
of the West German coal mining industry, has developed a process for the adsorption of $\mathrm{SO}_{2}$ and the oxides of nitrogen on activated charcoal. ${ }^{8.5}$ Gaseous effluent streams at many nuclear power plants contain charcoal adsorber systems to remove radioactive iodine, and studies are now in progress to apply these systems to the removal of the radioactive noble gases. ${ }^{86-89}$ The Allied Chemical Corporation has developed a scrubber system to remove traces of $U_{6}, H F$, and $F_{2}$ from process effluent streams of their $U F_{6}$ plant. ${ }^{3}$ This proprietary system consists of a specially designed tower packed with "coke" and utilizes a $\mathrm{KOH}$ solution as the scrubber medium. Since this system is proprietary and its efficiency for removal of fluoride-bearing impurities has not been published, it has been assigned a relatively low removal efficiency of $90 \%$ (i.e., a DF of 10). Proprietary technology is generally avoided in generic studies, but this system is a developed technique and appears to have technical advantages over the known alternative that uses consumable wet mineral wool filters. ${ }^{90}$

Hydrogen burner and flame arrestor. In all case studies, a hydrogen burner and a flame arrestor are used on the reduction off-gas stream to convert all forms of sulfur to $\mathrm{SO}_{2}$ and hydrogen to water.

\subsubsection{Liquid radioactive waste treatment systems}

The model $\mathrm{UF}_{6}$ facility generates liquid effluents which contain uranium, transuranics, their daughter products, and fission products. These liquids are produced in the scrap recovery operations and are found in the scrubbers that are used in the airborne radioactive waste treatment systems. The major objectives of the liquid waste treatment systems are: (1) to return the uranium to the process along with a minimum amount of impurities, where economically practical; and (2) to prevent the release of small quantities of uranium and other radionuclides. Various unit process operations are used to treat liquid effluents. The scrap recovery system utilizes a peroxide precipitation to separate the uranium from undesirable impurities and to prevent its release to the environment. Liquids containing radioactivity are evaporated to retain both soluble and insoluble impurities, and the purified condensate is recycled for reuse. Liquids containing radioactivity of process origin are not released to the environs. Miscellaneous liquid wastes are normally free of radioactivity. When radioactivity is detected in this stream, the liquid is transferred to a storage area for subsequent evaporation. The treatment methods that have been considered for the liquid effluents are described in the following sections.

Holding and settling. ${ }^{91}$ The uranium in the liquid wastes is present as sodium or potassium diuranate or some form of uranium oxide which is in solution or suspended as solids. The amount of uranium in solution can be particularly high when the solution has not been retained long enough to achieve complete precipitation (i.e., long enough to approach the equilibrium solubility of these compounds). The use of holding tanks to allow time for additional precipitation, coagulation of colloidal particles, and settling of solid particles is an important treatment technique. A holdup time of 16 to $20 \mathrm{hr}$ significantly increases the amount of uranium that can be removed by filtration. Where the holding technique is utilized, gravity sedimentation allows the waste to be separated into a solids-rich portion and a relatively clear supernate. 
Filtration and centrifugation. ${ }^{9-2 y-4}$ Filtration is used to remove the insoluble uranium from liquid waste streams. The operations are of the type known as clarification, since only a relatively small (100 ppm or less) amount of solids is present in the streams. Continuous rotating drum filters are used in this study, but other types of filters could be used. The difference in cost would be minimal in comparison to the total plant cost and would not significantly affect the charges associated with waste treatment (Sect. 6.0).

In those cases where the waste stream is held for 16 to $20 \mathrm{hr}$ to allow additional precipitation, the solids settle and a more-concentrated slurry is formed in the bottom of the tank. In such cases, a centrifuge is used to separate the solids from the (more-concentrated) stream prior to filtration. The large density difference between the liquid and solid phases is conducive to this type of separation. The centrifuge removes the bulk of the solids and, in conjunction with subsequent filtration of both the light stream from the centrifuge and the supernate from the clarifier, all but the finest particles are removed from the stream.

Evaporation. ${ }^{45-97}$ Evaporation is commonly used in the chemical industry to concentrate aqueous solutions by boiling off the water and leaving behind most of the dissolved solids and materials having vapor pressures lower than water. ${ }^{98}$ Similarly, evaporation is very effective in separating dissolved radioactive solids from waste water, and essentially all sizes and types of evaporators have been used in the nuclear industry. However, materials which have vapor pressures higher than water or which combine with water to form high-vapor-pressure materials are difficult to separate from water by evaporation.

In evaporating radioactive waste, care must be taken to avoid too rapid boiling or foaming since each tends to cause the entrainment of minute particles of radioactive solids or liquid droplets in the vapor rising from the surface of the boiling liquid. Also, the velocity of the vapor must be kept low and the distance the vapor travels upward (disengaging space) must be as long as practicable to encourage particles and droplets to fall back into the liquid rather than be carried over into the condenser with the vapor. A variety of devices to de-entrain particles and droplets can be incorporated into evaporators to improve DFs to as high as 100,000 or even a million. Such devices work by changing the direction of the vapor path, causing particles and droplets to impinge on and adhere to metal surfaces from which they can later be flushed back into the liquid. Wire mesh filters, sieve trays, bubble-cap trays, and centrifugal separators are among such devices.

Evaporators for radioactive waste can vary from simple pots with steam heating pipes coiled inside to elaborate devices having pumps which circulate the feed through outside heaters and compressors which squeeze more heat efficiency from the hot vapor (vapor compression evaporators). In general, maintenance is less expensive and operation is more satisfctory for simple evaporators equipped with adequate auxiliaries to achieve the required DF. Depending on the amount of dissolved solids in the waste fed to an evaporator, a volume reduction of 10 to 50 can usually be achieved in the radioactive thick liquor (bottoms or concentrate) while maintaining the level of radioactive material in the condensate (overhead or distillate) 10,000 to a million times lower than that in the bottoms. To achieve such good separation, however, no foamover can be permitted and entrainment must be kept to a minimum. Therefore, laundry waste containing detergents or other foam-producing materials must be given a pretreatment before evaporation. Liquid waste evaporators should be tested before being used on actual waste streams. This is probably the only reliable method of demonstrating that the desired DF 
values can be achieved over the extremes of conditions expected. Stable isotopes and tracer levels of radioactivity can be used in these tests. An overall decontamination (separation) factor of more than 10,000 between condensate (distillate) and thick liquor (concentrate) is generally expected for nonvolatile radioactive contaminants treated in single-stage evaporators; a value of 10,000 was assumed in this study.

\subsubsection{Solid radioactive waste treatment methods ${ }^{99-101}$}

A principal operational function of the waste processing area is to reduce the volume of chemical solutions and waste solids so that they may be solidified and packaged for storage onsite or shipment to a licensed commercial burial ground. The wastes include aqueous residues, sludge from evaporative processes, incinerator ash, and nonburnable items that are slightly contaminated with radioactive materials. In Cases 1-5a, the solid waste residues from the scrap recovery operation, along with other miscellaneous wastes, are packaged in drums for storage onsite or shipment to a licensed commercial burial ground. In Case $5 \mathrm{~b}$, the solid wastes and the concentrated bottoms from the evaporation of radioactive liquids are incorporated in cement. This technique is an established technology that is widely practiced at power reactor stations and is available for immediate use at $\mathrm{UF}_{6}$ plants. ${ }^{102}$ Part of the waste may be shipped for storage in Federal repositories, if the proposed new Federal regulations ${ }^{1103}$ are adopted, since the material (filter fines and spent bed material) is slightly contaminated with plutonium.

\subsection{Selection of Case Studies}

Five conceptual case studies, each chosen to reflect a decreasing release of radioactivity for an increasing sophistication of radioactive waste treatment, were selected for the recycle uranium conversion and $U F_{6}$ plant. Inclusion of specific treatment techniques was not based on cost, but on the effectiveness in reducing the radioactivity of plant effluents. All of the treatment methods included have been utilized in either pilot-plant or industrial scale operations, although no existing recycle plant has used some of the treatment methods selected for the advanced cases. The efficiency of a treatment system or process operation for retention of radioactive material is expressed as a DF (i.e., the ratio of the amount of material entering the operation to that released in the waste effluent from the operation).

Case 1 is the "base case" for the model plant and represents a facility which could be operated under present licensing regulations. Additional treatment systems are added in each succeeding case study. The principal objective of each treatment system is to decrease the quantity of radioactivity released to the environment, although noxious chemical releases have also been reduced in some instances. The cases studied, along with the treatment systems, are summarized in Table 4.8 . 
4.5 Description of Case Studies and Calculation of Source Terms

The treatment methods used in the individual case studies are discussed in the following sections. The source terms (i.e., the concentrations of radionuclides in the effluents and the annual amounts of radioactive materials discharged in the effluents), are presented in Table 4.9. The parameters used in calculating the source terms are presented in Sect. 4.5.12. The amounts of nonradioactive noxious materials (nitrate, fluoride, etc) are listed in the material balance tables (Tables 4.1-4.4).

\subsubsection{Feed storage and concentration}

An adjoining fuel reprocessing plant furnishes the feed to the $U F_{6}$ facility via direct pipeline to an accountability tank and then to a storage and feed tank. Only small quantities of water and nitric acid are found in the purge streams emanating from these areas. These air streams are released directly to the environment in all case studies.

Concentration of the uranyl nitrate solution is performed in a thermosiphon evaporator where the uranium is concentrated by a factor of 4 . The off-gas vapors report to a condenser for removal of water, which is returned to the reprocessing plant for reuse. No treatment systems are required for the sparge air streams from the condensate storage tanks for any of the case studies.

\subsubsection{Denitration and nitric acid recover:}

The denitration process is based on the thermal decomposition of uranyl nitrate hexahydrate to uranium trioxide by the following series of reactions:

$$
\begin{aligned}
& \mathrm{UO}_{2}\left(\mathrm{NO}_{3}\right)_{2} \cdot 6 \mathrm{H}_{2} \mathrm{O} \rightarrow \mathrm{UO}_{2}\left(\mathrm{NO}_{3}\right)_{2(s)}+6 \mathrm{H}_{2} \mathrm{O}_{(g)}, \\
& \mathrm{UO}_{2}\left(\mathrm{NO}_{3}\right)_{2(s)} \rightarrow \mathrm{UO}_{3(s)}+\mathrm{N}_{2} \mathrm{O}_{4(k)}+1 / 2 \mathrm{O}_{2(g)} .
\end{aligned}
$$

The product of the dehydration and denitration reaction is usually a tetragonal type of $\mathrm{UO}_{3}$. This form is the most stable of the $\mathrm{UO}_{3}$ structures at the elevated temperatures employed for denitration. These temperatures generally lie between $300^{\circ} \mathrm{C}$ and $400^{\circ} \mathrm{C}$, a range chosen for two principal reasons. Below $300^{\circ} \mathrm{C}$, rapid and efficient denitration is difficult to achieve. Moreover, hydrated types of $\mathrm{UO}_{2}$ can form at low temperatures. Above $430^{\circ} \mathrm{C}, \mathrm{UO}_{3}$ begins to dissociate into $\mathrm{O}_{2}$ and $\mathrm{U}_{3} \mathrm{O}_{4}$.

Of the three methods generally used for the thermal denitration of UNH (viz., batch, stirred bed, and fluidized bed), the fluidized-bed technique was selected as the reference method. Superheated steam is used as the fluidizing medium, and the UNH, atomized by air, is sprayed into the fluidized bed. Uranyl nitrate is converted to $\mathrm{UO}_{3}$ particles which overflow to a collection vessel. The waste off-gas treatment system consists of a standard condenser and a condensate storage system. 


\subsubsection{Feed preparation for $\mathrm{UO}_{3}$ reduction}

The preparation of the $\mathrm{UO}_{3}$ feed material for the reduction step is very important in obtaining a high-quality $\mathrm{UO}_{2}$ product for hydrofluorination. The process variables that must be carefully controlled are temperature, particle size, rate of dehydration, sulfate content, and stoichiometry.

The rate of reduction increases with an increase in temperature, but an excessively high temperature can produce a refractory $\mathrm{UO}_{2}$ product. The particle size of the $\mathrm{UO}_{3}$ influences both the particle size of the $\mathrm{UO}_{2}$ product and the rate of reduction. In general, the particle size of the $\mathrm{UO}_{2}$ resembles that of the parent $\mathrm{UO}_{3}$ and a high interfacial area produces the most rapid reduction. A more reactive oxide is produced if the thermal denitration is performed such that hydrated oxides are formed first by low-temperature denitration followed by complete dehydration at a somewhat higher temperature. The addition of sulfate (2000 to $3500 \mathrm{ppm}$ ) before denitration improves the reactivity of the $\mathrm{UO}_{3}$ product. Although the mechanism is not clearly understood, the sulfate ion apparently increases lattice strains in the $\mathrm{UO}_{3}$ and, in turn, increases its surface area. During its production or during subsequent handling, $\mathrm{UO}_{2}$ can become oxidized. Thus, at elevated temperatures under a partial pressure of oxygen, the $\mathrm{UO}_{3}$ content of the $\mathrm{UO}_{2}$ increases. The presence of $\mathrm{UO}_{3}$ is not desirable because of the adverse effects in the subsequent fluorination step: (1) a higher consumption of fluorine, (2) the evolution of more heat, and (3) the possibility that some of the $\mathrm{UO}_{3}$ may not be completely fluorinated because of the relatively slow fluorination rate of $\mathrm{UO}_{3}$.

Feed preparation off-gas treatment, Case $l$. The preparation of the feed for the reduction of $\mathrm{UO}_{3}$ involves the typical mechanical operations for producing particles of a uniform size (i.e., milling, mixing, and screening). Large amounts of small particles are dispersed into the process off-gas during these operations. An efficient filtration system utilizing a cleaner bag filter and a pulse jet bag filter in series is used to remove 99.975\% (DF $=4000)$ of these particles. The pulse jet bag filter is also used in conjunction with a centrifugal separator (same rated overall efficiency) to remove dry waste material discharged by the vacuum cleaner and maintenance system.

The gaseous effluent from the Case 1 off-gas treatment system consists of $1.17 \times 10^{5}$ standard liters per minute $(\mathrm{slm})$ of $\mathrm{N}_{2}(4140 \mathrm{scfm}), 3.15 \times 10^{4} \mathrm{slm}$ of $\mathrm{O}_{2}(1110 \mathrm{scfm}), 18 \mathrm{slm}$ of water vapor $(0.7 \mathrm{scfm})$, and small amounts of uranium as particulate material. The water released amounts to $21.4 \mathrm{~kg}(47.2 \mathrm{lb})$ per day, and the uranium released totals approximately $97 \mathrm{~g}$ per day, which represents a major fraction of the total uranium released from the facility.

Feed preparation off-gas treatment, Case 2. The objective in this case study is to reduce the quantity of particulates in the off-gas stream by additional treatment methods. A second pulse jet bag filter is added, which removes an additional $86 \%$ of the uranium dust to produce an overall removal efficiency of $99.9965 \%(\mathrm{DF}=28,570)$. The uranium content of the off-gas stream is reduced by a factor of 7 to $13.6 \mathrm{~g} /$ day.

Feed preparation off-gas treatment, Cases 3-5. A HEPA filter bank is added as a final treatment system to reduce the uranium content of this process stream to trace amounts. The overall process containment is now greater than $5 \times 10^{7}$, and the amount of uranium released has been reduced to less than $7 \mathrm{mg}$ per day. 


\subsection{4 $\mathrm{UO}_{3}$ reduction}

Uranium dioxide is prepared by the reduction of $\mathrm{UO}_{3}$ with hydrogen, utilizing the fluidized-bed reactor technique developed at Oak Ridge by the Union Carbide Corporation Nuclear Division. ${ }^{26.28}$ The reaction is represented by the equation

$$
\mathrm{UO}_{3(s)}+\mathrm{H}_{2(g)} \rightarrow \mathrm{UO}_{2(s)}+\mathrm{H}_{2} \mathrm{O}_{(g)}
$$

The reference method employs two consecutive beds (or stages), although some single-stage units are used in the industry. The reduction gases are produced by dissociating ammonia at $900^{\circ} \mathrm{C}\left(1650^{\circ} \mathrm{F}\right)$; usually excess nitrogen is added to secure sufficient gas velocities of about 1 fps for satisfactory fluidization. Twice the stoichiometric amount of $\mathrm{H}_{2}$ (100\% excess) is used. Heat is applied to the reactor at the beginning of a cycle to increase its temperature from ambient to a value in the range of $540^{\circ} \mathrm{C}$ to $620^{\circ} \mathrm{C}\left(1000^{\circ} \mathrm{F}\right.$ to $\left.1150^{\circ} \mathrm{F}\right)$. Once the reaction has been initiated, heat must be removed from the system because of the exothermic nature of the reduction. Careful control of the temperature is essential for the production of an easily fluorinated product.

Reduction off-gas treatment, Cases 1-3. The most troublesome materials found in this waste stream include $\mathrm{H}_{2} \mathrm{~S}, \mathrm{H}_{2}$, and uranium dust. Uranium is removed by passing the off-gas through two porous metal filters in series, which reduces the uranium content by a factor of $10^{5}$. Hydrogen and $\mathrm{H}_{2} \mathrm{~S}$ are oxidized by burning in $50 \%$ excess air. A flame arrestor is located in front of the burner in the process gas stream to prevent flashback. The effluent released to the environment consists of $1070 \mathrm{slm}$ of $\mathrm{N}_{2}(38 \mathrm{scfm}), 96 \mathrm{slm}$ of $\mathrm{O}_{2}(3.4 \mathrm{scfm}), 725 \mathrm{slm}$ of $\mathrm{H}_{2} \mathrm{O}$ (26 scfm), $7.3 \mathrm{slm}$ of $\mathrm{SO}_{2}(0.3 \mathrm{scfm})$, and $5 \mathrm{~g}$ of uranium per day.

Reduction off-gas treatment, Cases 4-5. A high-energy venturi scrubber utilizing a $\mathrm{KOH}$ recirculating system operating between 10 and $2 \% \mathrm{KOH}$ is added to the process waste treatment system to remove $98 \%$ of the $\mathrm{SO}_{2}$ and $99 \%$ of the remaining uranium. The scrubber is operated at $70^{\circ} \mathrm{C}\left(158^{\circ} \mathrm{F}\right)$ to prevent dilution of the scrubber liquid by water formed during combustion and to achieve an acceptable reaction rate between the caustic solution and the gaseous effluents. Approximately $600 \mathrm{~g}$ of $\mathrm{SO}_{2}$ and $50 \mathrm{mg}$ of uranium per day are released to the environment.

Reduction scrub liquor, Cases 4-5. About 1100 liters (300 gal) of spent $\mathrm{KOH}$ scrub liquor containing $\sim 5 \mathrm{~g}$ of uranium is regenerated daily by treating it with lime to precipitate $\mathrm{CaSO}_{4} \cdot 1 / 2 \mathrm{H}_{2} \mathrm{O}$ (Fig. 4.4). The mixture is centrifuged to produce a clean $\mathrm{KOH}$ stream suitable for recycle and a waste sludge that is sent to a spray evaporator for removal of water, which is exhausted as vapor through the process stack.

\subsubsection{Hydrofluorination of $\mathrm{UO}_{2}$ to $\mathrm{UF}_{4}$}

Uranium tetrafluoride is prepared by the reaction of $\mathrm{HF}$ with $\mathrm{UO}_{2}$ at temperatures of $350^{\circ} \mathrm{C}$ to $600^{\circ} \mathrm{C}\left(625^{\circ} \mathrm{F}\right.$ to $\left.1100^{\circ} \mathrm{F}\right)$ according to the equation

$$
\mathrm{UO}_{2(s)}+4 \mathrm{HF}_{(g)} \rightarrow \mathrm{UF}_{4(s)}+2 \mathrm{H}_{2} \mathrm{O}_{(g)} .
$$


Reaction conditions must be carefully controlled because of (1) the highly exothermic nature of the reaction $(43.2 \mathrm{kcal} /$ mole), (2) the reversible characteristics of the reaction, and (3) the variations that may occur in the preparation of the $\mathrm{UO}_{2}$ feed. A temperature that is too low will reduce the reaction rate and may lead to HF-water condensation and resultant corrosion problems. An excessively high temperature may produce a sintered $\mathrm{UF}_{4}$ coating on the $\mathrm{UO}_{2}$ particles, with an accompanying reduction in reaction rate. Both the history of the starting $\mathrm{UO}_{3}$ and its reduction (Sect. 4.5.4) have a marked effect on the hydrofluorination rate. The difference in volume between the reactants and the products can create problems in controlling gas flow in fluidized beds.

The model plant uses a fluidized-bed reactor, which is the preferred technique in the United States. The anhydrous HF flow (present in $10 \%$ excess over stoichiometric) is supplemented with nitrogen $(2830 \mathrm{slm}$ or $100 \mathrm{scfm}$ ) to improve the fluidizing characteristics of the bed. Two fluidized beds in series are used, with the first stage performing the function of a cleanup reactor for $\mathrm{HF}$ and the second stage for $\mathrm{UO}_{2}$. Approximately $70 \%$ of the conversion occurs in the primary hydrofluorinator. To prevent sintering at localized hot spots, external cooling is required in this reactor where most of the heat is liberated. Depending on the process system, heating or cooling may be needed for the secondary hydrofluorinator. Conversion efficiencies approaching $100 \%$ are quite common in the hydrofluorination process.

Hydrofluorination off-gas treatment, Cases l-3. Particulates are removed from the process off-gas stream by two porous metal filters in series which have a combined trapping efficiency of $99.999 \%$ ( DF $=10^{5}$ ). These filters are provided with a timed cycled blowback which returns the collected dust to the hydrofluorinator. The process off-gases are then treated for removal of $\mathrm{HF}$ by passage through a packed tower which utilizes a $\mathrm{KOH}$ recirculating system operating between 10 and $2 \% \mathrm{KOH}$. A HF removal efficiency of $99 \%$ and a zero efficiency for particulate removal are assumed in this study.

The gaseous effluent released to the atmosphere consists of $2830 \mathrm{slm}$ of $\mathrm{N}_{2}(100 \mathrm{scfm}), 1.3$ slm of $\mathrm{HF}(0.05 \mathrm{scfm})$, and $700 \mathrm{slm}$ of water vapor $(25 \mathrm{scfm})$. The quantities of $\mathrm{HF}$ and uranium released are $1.7 \mathrm{~kg} /$ day $(3.7 \mathrm{lb})$ and $0.60 \mathrm{~g} /$ day, respectively.

Hydrofluorination scrub liquors, Cases 1-3. Approximately 5400 liters (1440 gal) of untreated scrub liquors per day containing $158 \mathrm{~kg}(348 \mathrm{lb})$ of fluoride, $406 \mathrm{~kg}(895 \mathrm{lb})$ of potassium, and negligible quantities of uranium are recycled to the $\mathrm{KOH}$ regeneration system. Fluoride is removed by a lime treatment, the $\mathrm{KOH}$ solution is separated by centrifugation, and the remaining moist solid is transported to a spray dryer for complete removal of water; the resulting solids are drummed for disposal. The water vapor from the dryer is discharged from the process stack.

Hydrofluorination off-gas treatment, Cases 4-5. Further treatment is included to reduce the HF and uranium concentrations of this stream by a factor of 100 by adding a high-energy venturi scrubber utilizing a recirculating $\mathrm{KOH}$ solution. The uranium content of this off-gas stream after treatment is $6 \mathrm{mg} /$ day, while the content of $\mathrm{HF}$ is $17 \mathrm{~g} /$ day. The gaseous flow rates are the same as in the previous case studies.

Hydrofluorination scrub liquors, Cases 4-5. Liquid flow rates are about the same as in the preceding cases. A slightly larger amount of fluoride $(168 \mathrm{~kg}$ or $370 \mathrm{lb} /$ day $)$ and approximately $0.6 \mathrm{~g}$ of uranium are found in the untreated scrub liquors. The uranium is removed in a separate step, and the fluoride is precipitated as $\mathrm{CaF}_{2}$ and stored in 55-gal drums for ultimate disposal. Water is discharged as vapor from the process stack. 


\subsubsection{Feed preparation for UF fluorination}

A feed preparation step is required to obtain the optimum use of fluorine in the fluorination of UF 4 . The most critical part of this operation is to produce a uniform feed that will mix easily with the bed material and will fluorinate at a constant rate. A mill and blender system is used to prepare such a mixture.

Feed preparation off-gas treatment, Case $l$. Considerable quantities of airborne particulates are generated and enter the process off-gas treatment system. A cleaner bag filter and a pulse jet bag filter in series are used to remove the particulates from the process off-gas. A pulse jet bag filter is also used in conjunction with a centrifugal separator to recover the dust collected by a vacuum cleaner and maintenance system. The dust removal efficiency for both systems is $99.975 \%$.

The gaseous effluent released to the environment from this system is composed of 40,000 $\operatorname{sim}$ of $\mathrm{N}_{2}(1400 \mathrm{scfm}), 10,700 \mathrm{sim}$ of $\mathrm{O}_{2}(380 \mathrm{scfm})$, and small amounts of uranium dust. The uranium content discharged to the environs $(15.6 \mathrm{~g} /$ day) is approximately $10 \%$ of the total that is released from the plant.

Feed preparation off-gas treatment, Cases 2-3. An additional pulse jet bag filter with an estimated efficiency of $86 \%$ has been added to the treatment system. The DF of the filter train is estimated to be greater than 28,000 . The uranium content in the off-gas stream discharged to the environment is about $2 \mathrm{~g} / \mathrm{day}$, which is equivalent to a sevenfold reduction when compared with the previous case study. The gas flow rates are unaltered.

Feed preparation off-gas treatment, Cases 4-5. An HF-resistant HEPA filtration system is incorporated into the process off-gas stream to increase the DF by a factor of 2000 for particulates. The uranium released to the atmosphere from the feed preparation steps has been reduced to approximately $1 \mathrm{mg} /$ day.

\subsubsection{Fluorination of $U F_{4}$ to $U F_{6}$}

The model plant uses a fluidized-bed fluorinator as the reference method with $\mathrm{CaF}_{2}$ as a diluent to control the highly exothermic reaction

$$
U F_{+(s)}+F_{2(g)} \rightarrow U F_{(q))}\left(\triangle H^{\circ}=-6 \mathrm{kcal} / \text { mole }\right)
$$

Excellent conversion of $\mathrm{UF}_{4}$ to $\mathrm{UF}_{6}$ can be obtained when operating in the temperature range of $425^{\circ} \mathrm{C}$ to $565^{\circ} \mathrm{C}\left(800^{\circ} \mathrm{F}\right.$ to $\left.1050^{\circ} \mathrm{F}\right)$. The reaction rate is extremely fast under these conditions and increases rapidly with temperature. Such conditions can place a heavy load on the reactor. Hence, $\mathrm{CaF}_{2}$ is used in the bed as a heat exchange medium and to dilute the $U F_{4}$. Air drawn from the room is used for cooling and functions as part of the building ventilation. The fluorides of most of the radioactive impurities in the $U_{4}$ are nonvolatile and remain with the bed material or are ejected with the fines to the process off-gas stream.

Fluorination off-gas treatment, Cases $1-2$. The vapors from the fluorinator contain $\mathrm{UF}_{6}$ product, $\mathrm{HF}$, excess $\mathrm{F}_{2}$, nitrogen, and particulate material $\left(\mathrm{CaF}_{2}\right.$ fines, unreacted $U F_{4}$, and impurities). The solid material is removed by two porous metal filters in series, and the $U F_{6}$ 
product is removed in the cold trap system. The residual gases are discharged to a $\mathrm{KOH}$ scrubbing system consisting of a spray tower, absorber, and a packed tower in series to remove uranium and noxious gases. The spray tower is assumed to be $80 \%$ efficient, and the packed tower $99 \%$ efficient, for the removal of $\mathrm{UF}_{6}, \mathrm{~F}_{2}$, and $\mathrm{HF}$.

After passage through the cold traps, the fluorinator off-gases contain, by volume, $0.08 \%$ $\mathrm{UF}_{6}, 6 \% \mathrm{~F}_{2}, 16 \% \mathrm{HF}$, and other gases (nitrogen used to fluidize the bed, seal leakage, and oxygen from the fluorination of oxide or oxyfluoride impurities in the $\mathrm{UF}_{4}$ ). The total fluoride load is $99.6 \mathrm{~kg} /$ day $(220 \mathrm{lb}$ ); the uranium load is $3.3 \mathrm{~kg} /$ day $(7.3 \mathrm{lb})$.

The gaseous effluent released to the atmosphere from the waste treatment system carries $0.2 \mathrm{~kg}(0.4 \mathrm{lb})$ of fluoride and $6.6 \mathrm{~g}$ of uranium per day.

Fluorination scrub liquors, Cases l-2. About 3270 liters per day (860 gal) of spent $\mathrm{KOH}$ solution containing $242 \mathrm{~kg}$ of potassium $(530 \mathrm{lb}), 94 \mathrm{~kg}$ of fluoride $(210 \mathrm{lb})$, and $3.3 \mathrm{~kg}$ of uranium $(7.3 \mathrm{lb})$ are regenerated and recycled to the process by precipitating the fluoride with lime. Uranium is present as a diuranate and is removed before the lime treatment.

Fluorination off-gas treatment, Case 3. The gaseous $\mathrm{HF}$ release is reduced to $20 \mathrm{~g} /$ day and the uranium to $0.7 \mathrm{~g} /$ day by adding a $\mathrm{KOH}$ coke box which is assumed to be $90 \%$ efficient for the removal of $F_{2}, H F$, and $U_{6}$. The other gaseous and liquid flow rates are the same as in the previous case studies.

Fluorination off-gas treatment, Cases 4-5. A 99.95\% efficient HF-resistant HEPA filter is added as a final step to remove small particulates. The uranium content of the process off-gas stream is reduced to less than $0.4 \mathrm{mg} /$ day. Flow rates for all other effluents (both gaseous and liquid) are the same as in Case 3.

\subsubsection{Fluorine generation and waste treatment}

Fluorine is produced by the electrolysis of HF in an anhydrous electrolyte of KF-2HF. Passage of a direct current through the melt liberates fluorine at the anodes and hydrogen at the cathodes. Anhydrous HF is supplied to the process on demand. A typical cell is of 6000-A capacity containing $3000 \mathrm{lb}$ of electrolyte in a Monel vessel. The anodes are made of carbon and the cathodes of steel. Large quantities of heat are removed from the cells by cooling coils containing circulating water. The cells operate under corrosive conditions and must be rebuilt periodically. The life of each cell is approximately 40 million A-hr, and $20 \%$ of the charge in each cell is discharged as waste. From the 16 cells at the facility (14 operating continuously, 1 on standby, and 1 being recharged), the model plant discharges an estimated 4 metric tons of nonradioactive cell sludge per year. This material is neutralized with a lime slurry, centrifuged, and transferred to a spray dryer for the removal of water. The solids are stored in drums for disposal.

The gaseous treatment system is designed to reduce the fluoride release rate and to eliminate the possibility of a hydrogen explosion. The hydrogen stream from the cells is passed through the following treatment systems: (1) porous metal filters to remove particulates, (2) a flame arrestor to eliminate the possibility of flame propagation from the burner, (3) a burner to oxidize hydrogen to water vapor, and (4) a high-energy venturi scrubber and a packed tower in series to remove HF. The scrub liquors are treated with lime to precipitate $\mathrm{CaF}_{2}$ and to 
regenerate $\mathrm{KOH}$. The ventilation air contains such low concentrations of $\mathrm{HF}$ and $\mathrm{F}_{2}$ (originating from occasional small leaks and general maintenance procedures) that it is released from the stack without scrubbing. The cell maintenance ventilation air contains HF only during cell dismantling, which occurs on the average of 30 min every 3 days. Because of its sporadic nature and low HF content, this stream is released via a stack without scrubbing. The flowsheet for the treatment system and the material flows are presented in Fig. 4.3 and Table 4.3 , respectively. The same treatment is used for all case studies.

\subsubsection{Scrap recovery}

Uranium powders collected from off-gas filters and much of the residues from fluorination reactors are returned directly to the process by placement into the powder vessels preceding the appropriate process step; however, uranium-bearing residues that contain materials undesirable in the main process are treated for uranium recovery. These wastes consist of uranium-bearing floor cleanups, potassium diuranate separated from the scrubber solutions, and other uranium containing solids. The uranium is dissolved in nitric acid, and any remaining insoluble material is removed by filtration. The metal is precipitated as the tetroxide by the addition of ammonia and hydrogen peroxide. The precipitate is removed from the mother liquor by centrifugation and clarification and subsequently calcined and returned to the process.

Scrap recovery off-gas treatment, Cases $1-3$. The off-gas treatment system consists of spray dryers, evaporators, and a bank of HEPA filters. The spray dryers and evaporators generate large amounts of water vapor, and the uranium dissolver produces significant quantities of nitrogen oxides. The amount of uranium released from the scrap recovery and ash handling system is $1.2 \mathrm{~g} /$ day, with the majority of it originating from the ash handling system.

Scrap recovery off-gas treatment, Cases 4-5. An additional HEPA filter system with an estimated efficiency of $99.5 \%$ is added to the process off-gas treatment system. A DF of $4 \times 10^{5}$ is assumed as the efficiency of the filter train for particulates. The uranium released to the atmosphere has been reduced to $6 \mathrm{mg} /$ day.

\subsubsection{Ventilation system}

The process building is serviced by a building ventilation system that consists of a pressurized supply and an exhaust through two elevated stacks. Ventilation is provided on a once-through basis with appropriate winter heating. The air change rates for the process areas are greater than those normally used in the chemical industry in order to ensure control of noxious fumes and to provide comfortable working conditions. The contributors to each of the two stacks are given in Fig. 4.6, flow rates are presented in Table 4.5, and descriptions are given below.

The exhaust stack carries the ventilation air from the fluorination section and the decontamination areas of the building. Both of these areas are separately partitioned from the rest of the processing area and are separately ventilated. In Cases 1-3, the discharged air is filtered by two banks of HEPA filters in series. Four grams of uranium is released daily in a 
gas flow of $4.25 \times 10^{5} \mathrm{slm}(15,000 \mathrm{scfm})$. A pulse jet bag filter is incorporated in Cases 4 and 5 to reduce the uranium release rate to $40 \mathrm{mg} /$ day.

The second stack, which is comprised of four separate systems, carries ventilation air from the remaining parts of the building. The main process area is adequately ventilated using a system of supply and return ducts. Since the flow rate is large for this stream $\left(3.40 \times 10^{6} \mathrm{slm}\right.$ or $1.20 \times 10^{5} \mathrm{scfm}$ ), no filtration units are provided in the early case studies (Cases 1-4). The uranium release rate of $30 \mathrm{~g} /$ day is reduced by a factor of 1000 in Case 5 by the addition of a pulse jet bag filter. The process support ventilation air (waste treatment, chemical scrubbing) is drawn in through the sides of the building and discharged without treatment. The cylinder filling section is compartmented from the other areas and has a separate supply and exhaust air system. The ventilation for this section is separate to permit shutdown in the event of a $U_{6}$ release during transfer operations. The cold trap section is also compartmented with a separate ventilation system to permit shutdown in the event of a $U F_{6}$ release.

The fluorine generation and cell maintenance area is supplied with a ventilation system that is separate and independent from other areas. The nominal working area pressure is slightly negative. The ventilation air is distributed into the area along the floor and is extracted along the roof. Nuclear materials are not permitted in the fluorine generation area, and no process gases are released to the area ventilation system under normal operation.

\subsubsection{Solid waste treatment}

The wet and solid waste processing operations are shown in Fig. 4.4. All waste solids and waste chemical solutions are sent to the waste processing area for reduction in volume so that they can be packaged in drums for storage or shipment to a licensed burial ground. In Case $5 b$ the liquid waste residues and solid wastes containing radioactivity are incorporated in cement. The cemented wastes are drummed and either stored onsite or transferred to a licensed burial ground. A mixture of $15 \%$ solids, $45 \%$ cement, and $40 \%$ water is generally satisfactory. Cementing of slightly soluble wastes is beneficial in reducing the potential long-term leaching of radioactive materials during storage. However, this extra cost over that of Case 5a does not reduce the amount of radioactive materials released from the plant.

\subsubsection{Calculation of source terms}

The radionuclide concentrations in the effluent streams are multiplied by the average specific activity values from Table 4.7 to calculate the source terms. The source terms for individual isotopes are obtained by multiplying the total radionuclide specific activity by the fraction of activity contributed by each given isotope. The source terms for the airborne effluents are listed in Table 4.9.

The design of the Case 1 model plant is based on contemporary designs for recycle $U_{F_{6}}$ plants, and the generation rate for radioactive particulates in processing areas is derived from that observed in two plants which produce $U F_{6}$ from natural uranium. The estimated concentrations of alpha and beta-gamma radioactive materials in the airborne effluent from the model plant are $3.12 \times 10^{-11}$ and $3.57 \times 10^{-11} \mu \mathrm{Ci} / \mathrm{ml}$, respectively. The releases from the 
model plant stacks are diluted by a factor of at least $10^{6}$ before reaching the boundary of the plant site at a distance of 1.5 miles. Thus, the model plant for Case 1 is well within the Federal guidelines listed for the release of radioactive materials (Code of Federal Regulations, Title 10, Part 20, Appendix B, Table II, Column 1) to unrestricted areas.

\subsection{References}

1. W. C. Ruch, D. A. Peterson, E. A. Gaskill, and H. G. Tepp, "Production of Pure Uranium Hexafluoride from Ore Concentrates," Chem. Eng. Prog., Symp. Ser. 56(15), 35 (1960).

2. Kerr-McGee Corporation, Oklahoma City, Oklahoma, Applicants Environmental Report Sequoyah Uranium Hexafluoride Plant, Docket 40-8027 (June 1972).

3. Allied-Gulf Nuclear Services, Barnwell, S. C., Environmental Report, UF Facility, Barnwell Nuclear Fuel Plant, Docket 70-1327, Rev. (September 1974).

4. Nuclear Fuel Services, Inc., Rockville. Md.. Environmental Report, NFS' UFo Plant, West Valley, New York, Docket No. 70-1701, Rev. (July 1975).

5. Letter from Ralph Deuster, Nuclear Fuel Services, to Kenneth Chapman, U.S. Nuclear Regulatory Commission, dated Sept. 22, 1976.

6. "Exxon Nuclear Tells Plan for Oak Ridge Facility," Nucl. News 19(4), 59 (1976).

7. Exxon Nuclear Company, Inc.. Richland, Wash., Nuclear Fuel Recovery and Recycling Center, Preliminary Safety Analysis Report. Docket 50-564 (June 1976).

8. C. A. Powell, "Current Manufacturing Processes Used in the United States for Mass Production of UF from Purified UO,", Proc. U.N. Intern. Conf. Peaceful Uses At. Energ.! Geneva, 1958, 4, Paper P/1840, p. 165 (1958).

9. J. G. Crawford, Fluorination of All Enrichments of Uranium Oxides, GAT-P-43, Goodyear Atomic Corp., Piketon, Ohio (June 1968).

10. D. M. Levins and P. G. Alfredson, Performance of a Thermosiphon Evaporator for Concentration of Uranyl Nitrate Solution, Australian Atomic Energy Commission Research Establishment, Lucas Heights, AAEC/E-278 (May 1973).

11. J. V. Smith, "Improving the Performance of Vertical Thermosiphon Reboilers," Chem. Eng. Prog. 70(7), 68 (1974). 
12. A. G. Fane, B. G. Charlton, and P. G. Alfredson, Thermal Denitration of Uranyl Nitrate in a Fluidized Bed Reactor, Australian Atomic Energy Commission Research Establishment, Lucas Heights, AAEC/E-284 (July 1974).

13. N. Levitz, D. E. Grosvenor, S. Vogler, F. G. Teats, and N. Quattropani, "Continuous Conversion of Uranium/Plutonium Nitrates to Oxides," Nucl. Technol. 20(1), 60 (1973).

14. W. C. Philoon, E. F. Sanders, and W. T. Trask, "Uranium Trioxide in a Fluidized Bed Reactor," Chem. Eng. Prog. 56(4), 106 (1960).

15. W. J. Bjorklund and G. F. Offutt, First Product Denitration Campaign with Enriched Uranium at ICPP, Idaho Nuclear Corporation, Idaho Falls, Idaho, IN-1475 (June 1971).

16. S. Vogler, D. E. Grosvenor, N. M. Levitz, and F. G. Teats, Development Studies on a Fluidized-Bed Process for Conversion of U/Pu Nitrates to Oxides. Part $I$. Laboratory-Scale Denitration Studies, Argonne National Laboratory, Argonne, Ill., ANL-7917 (April 1972).

17. S. N. Robinson and J. E. Todd, Plant-Scale Fluid-Bed Denitrator, Mallinckrodt Chemical Works, Weldon Spring, Mo., MCW-1509 (August 1966).

18. J. R. Bower, Chemical Technology Branch Annual Report, Fiscal Year 1969, Idaho Nuclear Corp., Idaho Falls, Idaho, IN-1314 (October 1969).

19. W. Lodding and L. Ojamaa, "Dehydration and Thermal Decomposition of Uranyl Nitrates in the Presence of Steam," J. Inorg. Nucl. Chem. 27, 1261 (1965).

20. S. Marshall, Summary Technical Report for the Period October 1, 1968 - December 31, 1968, National Lead Co., Cincinnati, Ohio, NLCO-1035 (January 1969).

21. C. D. Harrington and A. E. Ruehle, Uranium Production Technology, pp. 192-213, Van Nostrand, Princeton, N. J., 1959.

22. D. C. Brater, C. C. Littlefield, J. H. Pashley, and S. H. Smiley, Preparation of High Productivity Uranium Dioxide by Fluid Bed Reduction, Union Carbide Nuclear Company, Oak Ridge, Tenn, K-1329 (August 1957).

23. M. Kobayashi, D. Ramaswami, and W. T. Brazelton, "Pulsed-Bed Approach to Fluidization," Chem. Eng. Prog., Symp. Ser., 66(105), 47 (1970).

24. M. R. Garcia, Obtaining $\mathrm{UO}_{2}$ by Use of Cracked Ammonia and Reducing Agent, Universidad Nacional Autonoma de Mexico, Mexico City, Mexico, NP-17350 (1967) (in Spanish). 
25. R. P. Levey, Jr., A. de la Garza, S. C. Jacobs, H. M. Heidt, and P. E. Trent, "Fluid Bed Conversion of $\mathrm{UO}_{3}$ to $\mathrm{UF}_{4}, "$ Chem. Eng. Prog. 56(3), 43 (1960).

26. S. H. Smiley and D. C. Brater, "The Development of a High Capacity, Continuous Process for the Preparation of Uranium Hexafluoride from Uranium Oxides and Ore Concentrates," Proc. U.N. Intern. Conf. Peaceful Uses At. Energ., 2nd, Geneva, 1958, 4, Paper P/525, 153 (1958).

27. A. H. Sutton, J. C. Bishop, M. H. Cohen, and K. J. Stahman, "Reduction and Hydrofluorination of Uranium Concentrates by Fluid Bed Technique," Chem. Eng. Prog., Symp. Ser. 62(15), 20 (1966).

28. D. C. Brater, D. L. Castro, L. A. Dean, J. H. Pashley, and S. H. Smiley, "Development and Production Experience with Mechanically Agitated Fluid Beds as Applied to the Hydrofluorination of Fine Uranium Oxide Powders," Chem. Eng. Prog., Symp. Ser., 62(15), I (1966).

29. C. D. Harrington and A. E. Ruehle, Uranium Production Technology, pp. 214-44, Van Nostrand, Princeton, N. J., 1959.

30. A. P. Huber, J. Dykstra, and B. H. Thompson, "Multi-Ton Production of Fluorine for Manufacture of Uranium Hexafluoride," Proc. U.N. Intern. Conf. Peaceful Uses At. Energy, 2nd, Geneva, 1958, Geneva Conf. 4, Paper P/524, 172 (1958).

31. C. D. Harrington and A. E. Ruehle, Uranium Production Technology, pp. 468-72, Van Nostrand, Princeton, N. J., 1959.

32. C. C. Littlefield, Recovery of Fluorine from Feed Plant Vent Gases, Union Carbide Corp., Nuclear Div., Oak Ridge Gaseous Diffusion Plant, KLD-59, Part 3 (May 1955).

33. S. H. Smiley, D. C. Brater, C. C. Littlefield, and J. Pashley, Important Role of Elemental Fluorine in Uranium Processing Operations, Oak Ridge Gaseous Diffusion Plant, K-1518 (December 1966).

34. Paducah Gaseous Diffusion Plant, The Procedure Used in Disconnecting, Rebuilding, and Connecting Fluorine Cells, Paducah, Ky., KY-F-93 (April 1968).

35. S. H. Smiley, "Gas-Solid Reactors in Uranium Processing. A Critical Review," in Progress in Nuclear Energy, Series IV, Technology, Engineering and Safety, Vol. 4, C. M. Nicholls (Ed.), Pergamon, New York, 1961.

36. W. R. Pedigo, C. R. King, L. A. Dean, J. E. Owen, and S. Bernstein, "Fluidized Bed Recovery of Fluorine in the Manufacture of UF 6 ," Chem. Eng. Prog., Symp. Ser. 62(15), 12 (1966). 
37. S. H. Smiley, D. C. Brater, C. C. Littlefield, and J. H. Pashley, "Quantitative Recovery of Uranium Hexafluoride from a Process Gas Stream," Ind. Eng. Chem. 5l(2), 191 (1959).

38. F. D. Toor, "Application of Fluidized Bed in Atomic Energy," Nucleus (Lahore) 5, 70 (July-December 1968).

39. Goodyear Atomic Corp., UF to $U F_{6}$ Conversion Facility and Equipment (Engineering Materials), Portsmouth, Ohio, CAPE-1550.

40. B. W. Penland, GAT Technical Seminars, Feed Plant Technology, Goodyear Atomic Corp., Portsmouth, Ohio, GAT-216, Pt. 3 (December 1955).

41. J. L. Powell, W. R. Foreshee, and S. Bernstein, "Recovery of Uranium Hexafluoride Vapors," Ind. Eng. Chem. 5l, 919 (1959).

42. S. R. Blum, Computer Sciences Division, Union Carbide Corp., Nuclear Div., Oak Ridge, Tenn., letter to J. Ford, ERDA, Oak Ridge, Tenn., Nov. 11, 1975.

43. M. J. Bell, ORIGEN - The ORNL Isotope Generation and Depletion Code, ORNL-4628 (May 1973).

44. J. E. Vath, Oak Ridge Gaseous Diffusion Plant, personal communication to J. W. Roddy, Nov. 13, 1975.

45. J. M. Friend, Functional Relationships for Minor Uranium Isotopes in $P W R$ and $B W R$ Spent Fuels, Oak Ridge Gaseous Diffusion Plant, Oak Ridge, Tenn., K-OA-2762 (August 1975).

46. A. de la Garza, Supplementary Testimony Related to Enrichment of Recycled Fuel from Light Water Reactors, U. S. Atomic Energy Commission, Barnwell Nuclear Plant, Docket No. 50-332, p. 4787 (November 1975).

47. Allied-Gulf Nuclear Services, Barnwell Nuclear Fuel Plant - Final Safety Analysis, Docket No. 50-332 (1969-1970).

48. R. D. Ross, Air Pollution and Industry, p. 344, Van Nostrand, Princeton, N. J., 1972.

49. C. J. Stairmand, "Removal of Dust from Gases," p. 365 in Process for Air Pollution Control, G. Nonhebel (Ed.), The Chemical Rubber Company, Cleveland, Ohio, 1972.

50. F. R. Cuthane, "Fabric Filters Abate Air Emissions," Environ. Sci. Technol. 8, 127 (1974).

51. R. G. Dorman et al., "Solid-Gas Separation: Equipment," p. 20 in Filtration (Supplement to Chem. Eng.) (November 1973). 
52. "A Guide to Dry Dust Collectors," Chem. Process. 39(1), 39 (1976).

53. E. Rothwell, "Fabric Dust Filtration," Chem. Eng. (London) No. 295, 138 (1975).

54. P. Swift, "Dust Control Related to the Bulk Delivery of Particulate Materials," Chem. Eng. (London), No. 295, 143 (1975).

55. K. J. Caplan, "High Efficiency Collection of Radioactive Dust," Heat. and Vent. 48, 74 (1951).

56. R. P. Levey, Jr., Developments in Porous Metal Media for Gas Filtration, Union Carbide Corporation Nuclear Division, Y-12 Plant, Oak Ridge, Tenn., Y-1235 (1959).

57. Pall Trinity Micro Corporation, "Sintered Stainless Steel Filters and Other Porous Metals," Cortland, N.Y., Bulletin M201 (1967).

58. D. B. Pall, "Filtration of Fluid Catalyst Fines from Effluent Gases," Ind. Eng. Chem. 45,1197 (1953).

59. W. Davis, Jr., High Efficiency Particulate Air Filters - State of the Art Summary Pertaining to Plutonia Aerosols, ORNL/TM-4463 (April 1974).

60. M. Hetland and J. L. Russell, Jr., "Adequacy of Ventilation Exhaust Filtering Systems for New Plutonium Facilities," p. 619 in Proceedings of the 12th AEC Air Cleaning Conference held in Oak Ridge, Tennessee, August 28-31, 1972, CONF-720823 (January 1973).

61. F. J. Linck and J. A. Geer, "In-place Testing of Multiple Stage HEPA Filters," p. 526 in Proceedings of the 13th AEC Air Cleaning Conference held in San Francisco, Calif., August 12-15, 1974, CONF-740807 (March 1975).

62. A. J. Oliver and C. L. Amos, "Ventilation Design for New Plutonium Recovery Facility," p. 320 in the Proceedings of the 13th AEC Air Cleaning Conference held in San Francisco, Calif., August 12-15, 1974, CONF-740807 (March 1975).

63. H. J. Ettinger, J. C. Elder, and M. Gonzales, Performance of Multiple HEPA Filters Against Plutonium Aerosols, Progress Report for Period January l through June 30, 1973, Report LA-5349-PR (July 1973).

64. H. J. Ettinger et al., "Size Characteristics of Plutonium Aerosols," p. 740 in Proceedings of the 12th AEC Air Cleaning Conference held in Oak Ridge, Tennessee, August 28-31, 1972, CONF-720823 (January 1973).

65. M. Gonzales, J. C. Elder, and H. J. Ettinger, "Performance of Multiple HEPA Filters Against Plutonium Aerosols," p. 501 in Proceedings of the 13th AEC Air Cleaning Conference held in San Francisco, California, August 10-15 1974, CONF-740807 (March 1975). 
66. USAEC Regulatory Guide, August 1973, Regulatory Guide 3.12, "General Design for Ventilation Systems of Plutonium Processing and Fuel Fabrication Plants."

67. C. A. Burchsted, Oak Ridge National Laboratory, personal communication to W. Davis, Jr., June 1974.

68. C. A. Burchsted, Oak Ridge National Laboratory, personal communication to M. B. Sears, Feb. 13, 1975.

69. "XVII Tests on HEPA Filters Reported by C. A. Burchsted," in Summary Report on Development of New Fluoride Resistant HEPA Filter Medium, by W. L. Belvin, M. A. Krimmel, H. C. Schwalbe, and E. N. Gleaton, HERTY Foundation, Savannah, Ga. (October 1974).

70. "A Guide to Scrubbers," Chem. Process. 38(9), 37 (1975).

71. E. W. Hanf and J. W. MacDonald, "Economic Evaluation of Wet Scrubbers," Chem. Eng. Prog. $7 l(3), 48$ (1975).

72. S. Calvert, "Engineering Design of Fine Particle Scrubbers," J. Air Pollut. Control Assoc. 24, 929 (1974).

73. C. J. Stairmand, "Removal of Dust from Gases," p. 364 in Process for Air Pollution Control, G. Nonhebel (Ed.), The Chemical Rubber Co., Cleveland, Ohio, 1972.

74. R. D. Ross, Air Pollution and Industry, p. 375, Van Nostrand Reinhold Co., New York, 1972.

75. C. J. Stairmand, "Removal of Grit, Dust, and Fume from Exhaust Gases from Chemical Engineering Processes," Chem. Eng. (London), No. 194, CE310 (1965).

76. G. D. Sargent, "Dust Collection Equipment," Chem. Eng. (N.Y.) 76(2), 130 (1969).

77. S. K. Kempner, E. N. Seiler, and D. H. Bowman, "Performance of Commercially Available Equipment in Scrubbing Hydrogen Chloride Gas," J. Air Pollut. Control Assoc. 20(3), 139 (1970).

78. H. Lux and H. Strange, "Results of a Five-Year Endeavor to Decrease Fluoride Emissions," Chem. Tech. (Leipzig) 1971 23(45), 264(1971) (In German).

79. K. Reither, "Reduced Emission of Gaseous Matter by Fitting of KT Gas Scrubbing Equipment," Wasser, Luft Betr. 1974, 18(10), 544(1974) (In German).

80. L. S. Harris, "Fume Scrubbing with the Ejector Venturi System," Chem. Eng. Prog. 62(4), 55 (1966). 
81. H. E. Gardenier, "Submicron Particulate Scrubbing with a Two-Phase Jet Scrubber," J. Air Pollut. Control Assoc. 24, 954 (1974).

82. J. S. Eckert and R. F. Strigle, Jr., "Performance of Wet Scrubbers on Liquid and Solid Particulate Material," J. Air Pollut. Control Assoc. 24, 961 (1974).

83. "High Energy Wet Scrubber Collects 99.99\% Emission," Chem. Process. 39(3), 79 (1976).

84. W. D. Lovett and F. T. Cunniff, "Air Pollution Control by Activated Carbon," Chem. Eng. Prog. 70(5), 43 (1974).

85. W. F. Bischoff and Y. Habib, "Processing: The FW-BF Dry Adsorption System," Chem. Eng. Prog. $7 l(5), 59$ (1975).

86. Seminar on Iodine Filter Testing, Karlsruhe, West Germany, CONF-731218 (Dec. 4-6, 1973).

87. R. D. Ackley and R. E. Adams, Removal of Radioactive Methyl Iodide from Steam-Air System (Test Series II), Oak Ridge National Laboratory, Oak Ridge, Tenn., ORNL-4180 (October 1967).

88. D. A. Collins, R. Taylor, and L. R. Taylor, "Adsorption of Krypton and Xenon from Argon by Activated Charcoal," United Kingdom Atomic Energy Authority, Risley, England, TRG-Report-1578 (September 1967).

89. J. L. Kovach, Krypton-Xenon Adsorption on NACAR Carbons, North American Carbon, Inc., Columbus, Ohio, Research and Development Dept., NACAR-1004 (December 1969).

90. C. E. Billings, C. K. Kurker, Jr., and L. Silverman, "Simultaneous Removal of Acid Gases, Mists, and Fumes with Mineral Wood Filters," J. Air Pollut. Control Assoc. 8(3), 191 (November 1958).

91. R. Miller, "Sedimentation," Water Wastes Eng. $l l, 40$ (1974).

92. R. G. Dorman et al., "Solid-Liquid Filtration: Equipment," p. 1 in Filtration (Supplement to Chem. Eng.) (November 1973).

93. C. A. Jahreis, "Filtration: Advances and Guidlines," Chem. Eng. (N.Y) 83(4), 80 (1976).

94. F. M. Tiller, "How to Select Solid-Liquid Separation Equipment," Chem. Eng. (N.Y.) $8 l(9), 116(1974)$.

95. R. D. Dierks and W. F. Bonner, "Wiped Film Evaporator for High-Level Wastes," Chem. Eng. Prog. 72(4), 61 (1976). 
96. C. B. Goodlett, "Concentration of Aqueous Radioactive Waste," Chem. Eng. Prog. 72(4), 63 (1976).

97. J. C. Petrie, R. I. Donovan, R. E. Van der Cook, and W. R. Christensen, "Vacuum Evaporator-Crystallizer Handles Radioactive Waste," Chem. Eng. Prog. $72(4), 65$ (1976).

98. H. W. Godbee, Use of Evaporation for the Treatment of Liquids in the Nuclear Industry, Oak Ridge National Laboratory, Oak Ridge, Tenn, ORNL-4790 (September 1973).

99. C. D. Johnson, "Modern Radwaste Systems: An Overview," Chem. Eng. Prog. 72(3), 43 (1976).

100. R. Bonniaud and C. Sombret, "Continuous Vitrification of Radioactive Wastes," Chem. Eng. Prog. 72(3), 47 (1976).

101. J. N. C. van Geel, H. Eschrich, and E. J. Detilleux, "Conditioning High-Level Radioactive Wastes," Chem. Eng. Prog. 72(3), 49 (1976).

102. A. H. Kibbey and H. W. Godbee, A Critical Review of Solid Radioactive Waste Practices at Nuclear Power Plants, Oak Ridge National Laboratory, Oak Ridge, Tenn., ORNL-4924 (March 1974).

103. U. S. Atomic Energy Commission, Transuranium Waste Disposal, 10 CFR Part 20 and Part 50, Fed. Regist. 39(178), 32921, 32922 (Sept. 12, 1974). 


\subsection{NONRADIOACTIVE RELEASES}

Various nonradioactive chemical compounds are released to the environment from both the recycle $U F_{6}$ facility and the fluorine production building. The chemicals that present the greatest health hazard include sulfur oxides, fluorides, and nitrogen oxides. Other off-gas constituents such as steam, nitrogen, and carbon dioxide are innocuous. The origin and treatment of these materials are discussed in Sect. 4.0 and will be summarized in the following sections.

\subsection{Airborne Effluents}

The most significant airborne chemical effluents released from the stacks of the two facilities are fluorine as fluoride, sulfur as sulfur oxides, and nitrogen as nitrogen oxides. Fluoride is released from the hydrofluorination process, the fluorine production process, and the fluorine facility ventilation system. Treatment of the effluent streams by scrubbing and demisting reduces the average fluoride concentration to approximately $2.5 \mathrm{ppm}$ in the air released from the stacks. Sulfur is added to the feed material as sulfate to improve the reactivity of the $\mathrm{UO}_{3}$. The concentration of $\mathrm{SO}_{x}$ in the air released to the environment is approximately $1.5 \mathrm{ppm}$. The nitrogen oxides are produced in the various combustion operations and in the denitration process and amount to about $4 \mathrm{ppm}$ in the discharged air.

As a point of reference for the chemical contaminants, the American National Standards Institute ${ }^{1,2}$ has recommended acceptable upper concentrations of $5 \mathrm{ppm}^{1}$ for $\mathrm{NO}_{2}$ and $3 \mathrm{ppm}^{2}$ for HF for repeated daily 8 -hr exposure. The releases at the stack meet these criteria.

\subsection{Liquid Effluents}

The design and operation of the recycle $U_{F}$ facility are such that no release of process chemicals to the environment occurs, other than the small amounts in the gaseous effluent. Condenser condensates and recovered nitric acid are returned to the reprocessing plant for reuse. Chemicals employed in the processing operations are either consumed by the process or collected in a solid wastc form. About $35 \mathrm{gpm}$ of potable water is used for saniiary purposes such as drinking fountains, showers, sinks, laboratory, and sanitary facilities. ${ }^{3}$ The effluent is discharged to the sewage treatment facility. All process water is treated for recycle of useful species, and the spent liquid and waste solid are spray dried for disposal.

\subsection{Thermal Releases}

Heat is released from the $\mathrm{UF}_{6}$ facility by: (1) building ventilation exhausts, (2) process exhausts, (3) evaporated water from cooling towers, (4) water effluents, and (5) boiler effluents. The plant, when operating at design capacity, generates about $7.1 \times 10^{6} \mathrm{Btu} / \mathrm{hr}$. Of the total energy released, approximately $30 \%$ originates from the fluorine building, $50 \%$ from the utility equipment, and $20 \%$ from the process condensers. About $80 \%$ of the cooling water (flow rate 
of $940 \mathrm{gpm}$ ) is used in the refrigeration compressors for the cold traps, the air compressors, and the fluorine plant. Since these areas are free of radioactive material, there is no possibility of radioactivity contaminating the cooling water in these areas. The remaining $20 \%$ is utilized in the condensers for uranyl nitrate concentration and denitration. The high pressure in the cooling water system should protect it from radioactive contamination if a leak should develop in one of the condensers. No chemicals are added to the cooling water system.

\subsection{References}

1. American National Standard Guide ANSI Z37.13-1971, Acceptable Concentrations of Nitrogen Dioxide, American National Standards Institute, Inc., 1430 Broadway, New York, N. Y.

2. American National Standard Guide USAS Z37.28-1966, Acceptable Concentrations of Hydrogen Fluoride and Inorganic Fluoride Dusts, American National Standards Institute, Inc., 1430 Broadway, New York, N. Y.

3. Allied-Gulf Nuclear Services, Barnwell, S. C., Environmental Report, UF 6 Facility, Barnwell Nuclear Fuel Plant, Docket 70-1327, Rev. (September 1974). 


\subsection{COSTS FOR RADWASTE TREATMENT}

Costs for the gaseous radioactive waste treatment cases and incorporation of the filter fines and liquid residue wastes in cement (Case 5b) for the model 1500-metric ton/year recycle $\mathrm{UF}_{6}$ plant are estimated as additions to the base plant. The capital costs, annual fixed charges, annual operating costs, total annual costs, unit conversion costs, and power costs for the cases are summarized in Table 6.1. The cost of converting the uranium nitrate product from the reprocessing plant to $\mathrm{UF}_{6}$ for shipping to the enrichment plant is considered as an additional reprocessing cost.

Annual fixed charges are estimated at $26 \%$ of total capital investment. This is typical of investor-owned fuel reprocessing and waste treatment facilities. ${ }^{1}$ The basis for calculation of the fixed charge rate and the operating cost is presented in Sect. 6.2. An annual operating expense is added to the annual fixed charge on capital to give the total annual cost of a radioactive waste treatment case. The annual operating (and maintenance) expense is calculated as follows: for conventional chemical equipment, such as towers, tankage, pumps, etc., it is estimated at $40 \%$ of the annual fixed charge; for gaseous radioactive waste treatment equipment, such as bag filters and venturi scrubbers, it is calculated based on published information; ${ }^{2-5}$ and for HEPA filters, it is based on experience at ORNL. ${ }^{6-8}$ This cost is then divided by the annual amount of uranium processed, or by the annual amount of electricity that was produced by the processed fuel, to obtain the cost of radioactive waste treatment per unit weight of fuel converted to $\mathrm{UF}_{6}$ or the contribution to the cost of power for each case. A recycle $\mathrm{UF}_{6}$ plant with a nominal production rate of 1500 metric tons/year can service about 50 reactors. It is assumed that the 50 reactors are comprised of 32 PWRs and 18 BWRs, based on a burnup of $33,000 \mathrm{MWd} /$ metric ton, an $80 \%$ load factor, and a $32.5 \%$ thermal efficiency for the PWRs, and a burnup of $27,500 \mathrm{MWd} /$ metric ton, an $80 \%$ load factor, and a $35 \%$ thermal efficiency for the BWRs. Costs are estimated in terms of 1973 dollars to make this report consistent with other reports in this series. ${ }^{4,9-13}$ No attempt is made to include the effect of inflation; however, based on the Marshall and Swift (M and S) Equipment Cost Index ${ }^{14}$ for chemical equipment, the 1976 costs will be about $36 \%$ higher than the 1973 costs. The cost estimates are expected to have an accuracy of about $\pm 30 \%$. The details of the cost estimates are provided in Appendix A.

\subsection{Capital Costs}

The capital cost of a radioactive waste treatment case is the sum of the direct cost and indirect cost. The interest during construction and the contingency allowance are included as indirect costs to simplify the calculations.

\subsubsection{Direct costs}

The major equipment components were sized and a base cost estimated by using either published information ${ }^{2-5}$ or the general methods for costing conventional chemical plant equipment for conceptual designs. ${ }^{15,16}$ The base cost for the gas treatment equipment (i.e., 
venturi scrubbers, bag filters, and HEPA filters) is the complete installed cost of the equipment. For other equipment, the base cost is the estimated purchase price. Appropriate factors are applied to the equipment cost to estimate the cost of installation, piping, instruments and controls, electrical, and quality assurance. ${ }^{15,16}$

Building requirements are estimated from equipment size with allowance made for auxiliary equipment such as pumps, condensers, etc. The costs of a warehouse building and other related facilities are not included. The total direct cost for each case is the complete equipment installed (material and labor) cost.

\subsubsection{Indirect costs}

For the purpose of this study, indirect costs are estimated as follows:

Percentage of direct cost

\begin{tabular}{lc} 
Engineering and supervision & 15 \\
Construction expense and contractor's fee & 20 \\
Engineering design (A-E) & 15 \\
Contingency & 45 \\
Other owner's cost $^{u}$ Interest $^{u}$ & 10 \\
Total & 35 \\
\hline
\end{tabular}

\subsection{Annual Fixed Charges and Operating Costs}

The annual fixed charges on invested capital are based on the Fuel Recycle Task Force ${ }^{17}$ annual fixed charge rate of $24 \%$, which was, in turn, based on the following assumptions:

$\begin{array}{ll}\text { Plant lifetime } & 15 \text { years } \\ \text { Capital investment in bonds } & 30 \% \\ \text { Capital investment in equity } & 70 \% \\ \text { Interest rate on bonds } & 5 \% \\ \text { Rate of return on equity (after taxes) } & 16 \% \\ \text { Federal income tax rate } & 50 \% \\ \text { State income tax rate } & 3 \% \\ \text { Local property tax rate } & 3.2 \% \\ \text { Annual cost of replacements } & 0.35 \% \\ \text { Annual property insurance rate } & 0.25 \%\end{array}$

${ }^{a}$ Interest is applied to the cumulative total cost at the rate of $8 \%$ per year over a 5 -year cash flow expenditure period. 
By present-day standards, the $5 \%$ bond interest rate is probably low. Increasing it to $8 \%$ would increase the fixed charge rate to about $26 \%$; thus, for this study a fixed charge rate on invested capital of $26 \%$ is assumed.

The annual operating and maintenance cost is calculated as $40 \%$ of the annual fixed charges for conventional chemical equipment. The annual costs of drums $(\$ 73,600)$ and cement $(\$ 47,300)$ in Case $5 \mathrm{~b}$ are included as additional operating charges. The cost for onsite storage of the drums or shipping offsite for storage or burial is not included. The annual operating cost of the gaseous waste treatment systems is calculated based on published information for equipment such as bag filters and liquid scrubbers. The operating cost for HEPA filters is based on experience at ORNL.

\subsection{Installed Equipment Costs}

The estimated direct and capital costs for equipment in Cases 2 through $5 \mathrm{~b}$ are presented in Table 6.2. The direct cost is the estimated installation (material and labor) cost of the equipment; the capital cost includes both direct and indirect costs.

\subsection{References}

1. Siting of Fuel Reprocessing Plants and Waste Management Facilities, ORNL-445I (July 1971).

2. C. J. Stairmand, "The Design and Performance of Modern Gas Cleaning Equipment," Inst. Fuel, London, Bull. 29, 181 (1956).

3. William Ellison, "Wet Scrubbers Popular for Air Cleaning," Power 115(2), 62 (February 1971).

4. A. D. Ryon and R. E. Blanco, Correlation of Radioactive Waste Treatment Costs and the Environmental Impact of Waste Effluents in the Nuclear Fuel Cycle for Use in Establishing "As Low As Practicable" Guides - Appendix A. Preparation of Cost Estimates for Volume I, Milling of Uranium Ores, ORNL-TM-4903, Vol. 2 (May 1975).

5. J. D. McKenna, J. C. Mycock, and W. O. Lipscomb, "Performance and Cost Comparison Between Fabric Filters and Alternate Particulate Control Techniques," J. Air Pollut. Control Assoc. 24(12), 1147 (December 1974).

6. C. O. Kirby, General Engineering Division, ORNL, private communication, May 1973.

7. J. J. Smith, Inspection Engineering, ORNL, private communication, May 1973.

8. G. Johnstone, Plant and Equipment Maintenance Service, ORNL, private communication, Máy 1973. 
9. B. C. Finney, R. E. Blanco, R. C. Dahlman, G. S. Hill, F. G. Kitts, R. E. Moore, and J. P. Witherspoon, Correlation of Radioactive Waste Treatment Costs and the Environmental Impact of Waste Effluents in the Nuclear Fuel Cycle - Reprocessing Light-Water Reactor Fuel, ORNL/NUREG/TM-6 (June 1976).

10. W. H. Pechin, R. E. Blanco, R. C. Dahlman, B. C. Finney, R. B. Lindauer, and J. P. Witherspoon, Correlation of Radioactive Waste Treatment Costs and the Environmental Impact of Waste Effluents in the Nuclear Fuel Cycle for Use in Establishing "As Low As Practicable" Guides - Fabrication of Light-Water Reactor Fuel from Enriched Uranium Dioxide, ORNL-TM-4902 (May 1975).

11. W. S. Groenier, R. E. Blanco, R. C. Dahlmąn, B. C. Finney, A. H. Kibbey, and J. P. Witherspoon, Correlation of Radioactive Waste Treatment Costs and the Environmental Impact of Waste Effluents in the Nuclear Fuel Cycle for Use in Establishing "As Low As Practicable" Guides - Fabrication of Light-Water Reactor Fuels Containing Plutonium, ORNL/TM-4904 (May 1975).

12. W. Davis, Jr., R. E. Blanco, B. C. Finney, G. S. Hill, R. E. Moore, and J. P. Witherspoon, Correlation of Radioactive Waste Treatment Costs and the Environmental Impact of Waste Effluents in the Nuclear Fuel Cycle - Reprocessing of High-Temperature Gas-Cooled Reactor Fuel Containing U-233 and Thorium, ORNL/NUREG/TM-4 (May 1976).

13. J. W. Roddy, R. E. Blanco, G. S. Hill, R. E. Moore, R. D. Seagren, and J. P. Witherspoon, Correlation of Radioactive Waste Treatment Costs and the Environmental Impact of Waste Effluents in the Nuclear Fuel Cycle - Fabricating of High-Temperature Gas-Cooled Reactor Fuel Containing Uranium-233 and Thorium, ORNL/NUREG/TM-5 (September 1976).

14. Chem. Eng. (N.Y.) 84(2), 7 (Jan. 17, 1977).

15. K. M. Guthrie, "Capital Cost Estimating," Chem. Eng. (N.Y.) 76(6), 114-42 (1969).

16. K. M. Guthrie, Process Plant Estimating, Evaluation and Control, Craftsman Book Company of America, Solano Beach, Calif., 1974.

17. Reactor Fuel Cycle Costs for Nuclear Power Evaluation, WASH-1099 (December 1971). 


\subsection{ENVIRONMENTAL IMPACT}

The radiological impact of the model recycle uranium conversion and $\mathrm{UF}_{6}$ plant is assessed by estimating radiation dose commitments to individuals and populations that result from 1-year exposure to the radionuclides discharged during normal operations. The effluents are dispersed in the environment by atmospheric transport. In this study, no process radioactive materials are released in liquid effluents. The resulting concentrations of radionuclides in the air and on the soil surface at various distances and directions from the model plant are then used to estimate the doses. Doses are calculated for each site and radioactive waste treatment case.

Potential pathways for radiation exposure to man from radionuclides released from a nuclear facility are presented schematically in Fig. 7.1. Although those shown are not exhaustive, they illustrate the principal pathways of exposure based on experience. External doses result from immersion in contaminated air, immersion in contaminated water, and exposure to contaminated ground surfaces. Internal doses result from the inhalation of contaminated air and the ingestion of contaminated food. Conservative assumptions which tend to maximize doses are used; for example, doses from atmospheric releases assume exposure to contaminated air and ground $100 \%$ of the time with no shielding and $100 \%$ of the food consumed is produced at the location of the dose calculation.

Radioactive materials taken into the body by inhalation and ingestion (internal exposure) continuously irradiate the body until removed by processes of metabolism and radioactive decay. A dose calculated for 1 year of radionuclide intake (internal-exposure pathways) is an estimate of the total dose an individual will receive integrated over the next 50 years of his life as a result of that 1 year of exposure (i.e.. dose commitment). All of the internal doses estimated in this report represent 50-year dose commitments. For those materials which either have short radioactive half-lives or are eliminated rapidly from the body, essentially all of the dose is received in the same year that the materials enter the body (i.e., the annual dose rate is about the same as the dose commitment). This is the case for most radionuclides in this study since the uranium radionuclides are eliminated from the body fairly rapidly and the half-lives of most of the fission products are short. However, ${ }^{91} \mathrm{Sr},{ }^{237} \mathrm{~Np},{ }^{238} \mathrm{Pu},{ }^{239} \mathrm{Pu},{ }^{240} \mathrm{Pu},{ }^{241} \mathrm{Pu}$, and ${ }^{244} \mathrm{Cm}$ are eliminated from the body very slowly and have long half-lives so that the individual will continue to receive a dose from the ingested material for many years after the exposure. Under these conditions, the approximate dose received in the year that the materials enter the body is obtained by dividing the dose commitment by 50 (i.e., approximately equal doses are received over a 50 -year period). Thus the average annual dose rate from, for example, ${ }^{237} \mathrm{~Np}$, ${ }^{239} \mathrm{Pu}$, or ${ }^{244} \mathrm{Cm}$ is only one-fiftieth of the dose commitment. If an individual is exposed to the recycle $U F_{6}$ plant effluents for the assumed 30-year operating life of the facility, his annual dose rate during the 30th year from the radionuclides with long radiological half-lives is about 30 times the annual dose rate for one year of exposure (i.e., $\sim$ three-fifths of the 50 -year dose commitment for 1 year of exposure). These generalized dose estimates are approximately correct for the conditions cited. However, a detailed calculation must be made to determine a more precise value for the actual dose received in a given year. Assumptions, models, and codes used to estimate radiation doses are given in ORNL $-4992 .{ }^{\prime}$

The radiation dose to organs may vary considerably for internal exposure from ingested or inhaled materials because some radionuclides concentrate in certain organs of the body. Estimates of radiation dose to the total body and major organs are considered for all pathways of internal exposure based on parameters applicable to an average adult. 
Radiation doses to the internal organs of children in the population differ from those of an average adult because of differences in metabolism, organ size, and diet. Differences between the organ doses of a child and those of an average adult by more than a factor of 3 would be unusual for all pathways of internal exposure except the atmosphere-pasture-cow-milk pathway.

The population total-body dose estimates are the sums of the total-body doses to individuals within 55 miles of the plant. Since radiation doses to the total body are relatively independent of age, ${ }^{2}$ the person-rem estimates are based on total-body doses calculated for adults. The population dose estimates for the various organs are the sums of the specific organ doses of the individuals within 55 miles of the plant. The person-organ-rem estimates are based on adult organ doses.

\section{I Radiological Impact of Airborne Effluents During Plant Operation}

The release of radioactive materials to the atmosphere is the only mode of environmental contamination from the recycle UF, plant. In this study, no process radioactive materials are released in liquid effluents.

\subsubsection{Models and assumptions}

AIRDOS. The FORTRAN computer code AIRDOS $^{3}$ is used to estimate individual and population doses resulting from the continuous simultaneous atmospheric release of airborne radioactive materials from the model plant. Pathways to man include: (1) inhalation of radionuclides in air, (2) immersion in air containing radionuclides, (3) exposure to ground surfaces contaminated by deposited radionuclides, (4) ingestion of food produced in the area, and (5) submersion (swimming) in water subjected to surface deposition from plumes. Doses are estimated for the total body as well as for the GI tract, bone, thyroid, lungs, muscle, kidney, liver, spleen, testes, and ovaries.

The area surrounding the nuclear facility is divided into 16 sectors. Each sector is bounded by radial distances of $0.5,1.0,2.0,3.0,4.0,5.0,10,15,25,35,45$, and 55 miles from the point of release. There are 176 areas lying outside the plant boundary, within 55 miles of the plant. Human population, numbers of beef cattle, and specification as to whether each of the 176 areas is used for producing vegetable crops or is a water area are required as input data.

The first part of AIRDOS ${ }^{3}$ is an atmospheric dispersion model (AIRMOD) which estimates concentrations of radionuclides in air at ground level and their rates of deposition on ground surfaces as a function of distance and direction from the point of release. Annual average meteorological data for the area are supplied as input for AIRMOD.

AIRMOD is interfaced with environmental models within AIRDOS to estimate doses to man through the five pathways. The most complex environmental model is a terrestrial model TERMOD. ${ }^{4}$ This model estimates radionuclide intake via ingestion of radionuclides deposited on crops, soil, and pastures. The intakes result from eating beef and vegetable crops and drinking milk. 
Population doses are summarized in the output tables of AIRDOS ${ }^{3}$ by nuclides, pathways, and organs. The highest individual doses in the area for the total body and for each organ are tabulated for each radionuclide, and the highest total-body and organ doses from all radionuclides in the source terms are calculated.

Meteorology. The basic equation used to estimate atmospheric transport to the terrestrial environment is Pasquill's Equation ${ }^{5}$ as modified by Gifford. ${ }^{6}$ For particulate releases, the meteorological $\chi / Q$ values are used in conjunction with dry deposition velocities and scavenging coefficients to estimate air concentrations and steady-state ground concentrations. Radioactive decay during plume travel is taken into account in AIRDOS. ${ }^{3}$ Daughters produced during plume travel must be added to the AIRDOS ${ }^{3}$ source term. Concentrations in air for each sector are used to calculate dose via inhalation and immersion in air. The ground deposits are also assimilated into food which, when ingested, results in additional dose via the food chain pathway.

The meteorological data required for the calculations are joint frequency distributions of wind velocity and direction summarized by stability class. Meteorological data ${ }^{7}$ from representative first-order weather stations in the Midwest (St. Louis, Mo.) and the southeast coast (Wilmington, N. C.) are used to calculate the concentrations of radioactive materials at a reference point per unit of source strength. The $\chi / Q$ values are calculated for sectors in the 16 principal compass directions bounded by radial distances of $0.5,1.0,2.0,3.0,4.0,5.0,10,15$, $25,35,45$, and 55 miles from the point of release.

Radioactive particulates are removed from the atmosphere and deposited on the ground through mechanisms of dry deposition and scavenging (washout). Dry deposition, as used in this analysis, represents an integrated deposition of radioactive materials by processes of gravitational settling, adsorption, particle interception, diffusion, and chemical-electrostatic effects and is calculated from deposition velocity, $\mathrm{Vg}$, for a 1 -year interval. Deposition velocity values for particles and reactive gases commonly range from 0.1 to $1.0 \mathrm{~cm} \cdot \mathrm{sec}^{-1}$. ${ }^{8,4}$ A value of $1.0 \mathrm{~cm} \cdot \mathrm{sec}^{-1}$ is used for calculation of ground concentrations of all radioactive particles. Scavenging of radionuclides in a plume is the process through which rain or snow washes out particles or dissolves gases and deposits them on ground or water surfaces. Methods for estimating scavenging coefficients can be found in ref. 10. A scavenging coefficient for particulates of $2.0 \times 10^{-5} \mathrm{sec}^{-1}$ is assumed for both the midwestern and the southeastern coastal sites.

Airborne release from the model plant. The radioactive effluents from the recycle $\mathrm{UF}_{6}$ plant are released from three separate stacks 50,40 , and $30 \mathrm{~m}$ high, respectively.

The $50-\mathrm{m}$ stack is assumed to have a gas flow rate of $3.74 \times 10^{5} \mathrm{slm}\left(1.32 \times 10^{4} \mathrm{cfm}\right)$, and the plume rise resulting from the momentum of the released gas is calculated by assuming a stack diameter of $1.016 \mathrm{~m}$. Similarly, it is assumed that the $30-\mathrm{m}$ stack (effective stack height due to plume rise is $50.3 \mathrm{~m}$ ) has a gas flow rate of $5.27 \times 10^{6} \operatorname{sim}\left(1.86 \times 10^{5} \mathrm{cfm}\right)$ and a stack diameter of $2.743 \mathrm{~m}$, and that the $40-\mathrm{m}$ stack (effective stack height due to plume rise is $45.9 \mathrm{~m})$ has a gas flow of $4.25 \times 10^{5} \mathrm{slm}\left(1.5 \times 10^{4} \mathrm{cfm}\right)$ and a diameter of $0.762 \mathrm{~m}$. The maximum $\chi / Q$ values for the long-lived radioactive particulates released from the three stacks for the 1.5-mile distances from the midwestern and coastal sites, respectively, are as follows: $50-\mathrm{m}$ stack, $2.25 \mathrm{E}-7$ and $1.88 \mathrm{E}-7 \mathrm{sec} / \mathrm{m}^{3} ; 40-\mathrm{m}$ stack, $2.54 \mathrm{E}-7$ and $2.38 \mathrm{E}-7 \mathrm{sec} / \mathrm{m}^{3} ; 30-\mathrm{m}$ stack, $2.48 \mathrm{E}-7$ and $1.86 \mathrm{E}-7 \mathrm{sec} / \mathrm{m}^{3}$. Since the stack releases are at different heights and the 
corresponding $\chi / Q$ 's at 1.5 miles from the plant (and at other distances) are different, dose estimates were calculated separately for each stack release and then combined to obtain the composite total-body and organ doses resulting from all airborne releases.

\subsection{Population}

Population distributions which would be representative of southeastern coastal and midwestern environments were derived. The population distributions are the average of population distributions around two fuel fabrication plants and one reprocessing plant for each case (i.e., the midwestern and southeastern coastal sites). Distributions for sites near St. Louis, Missouri, and Wilmington, North Carolina, are included in the averaging because the meteorological data used for atmospheric transport of radioactive substances are based on these areas. The Wilmington site also represents the half-annulus distribution which is representative of areas adjacent to the ocean.

Average population distributions are calculated from data sets for areas determined by the latitude-longitude coordinates specified in Table 7.1. Actual population distributions from these locations were summarized from 1970 Census Bureau tape records to obtain representative distributions for midwestern and southeastern coastal regions (Tables 7.2 and 7.3). The computer code PANS ${ }^{11}$ provides sector summaries for annuli bounded by distances of $0.5,1.0$, $2.0,3.0,4.0,5.0,10,15,25,35,45$, and 55 miles. The sector summaries correspond to the same sectors in the 16 compass directions for which $\chi / Q$ values are calculated. The computer code summaries of population data from census tapes are accurate beyond a 5-mile radius. Within 5 miles, where sectors represent relatively small areas, distributions are somewhat disconnected because census enumeration districts encompass several sectors while the population records are reported in a single sector. Averaging data from three locations smooth the major discontinuities.

Population distributions for the two sites of the recycle $U_{F}$ plant have somewhat different characteristics (Table 7.2 and 7.3). The average density within the 55-mile radial distance is 50 to 60 individuals per square mile for the coastal plain site, except for a factor of 5 increase to 289 individuals per square mile, representing a small city, in the 5- to 10 -mile annulus. The 9500-square-mile area encircling the coastal site is distinctly rural (58 individuals per square mile) in terms of population density. By comparison, the population density of the midwestern site within the 5 -mile radius is nearly twice as great $(95 \mathrm{vs} 55)$ as that for the coastal site. Beyond 5 miles, the density increases to 126 individuals per square mile at 10 miles and to 440 individuals per square mile in the 25- to 55-mile annulus. A large city is included in a portion of the 55-mile area encircling the recycle $U_{6}$ facility. The cumulative population in the midwestern site is approximately six times greater than for the coastal site. 


\subsection{Environmental Impact of the Recycle UF Plant}

\subsubsection{Radiation dose commitments from airborne effluents of the operating plant}

Concentrations of radionuclides in air and on the soil surface are used to estimate the radiation dose to individuals at various distances and directions from the model plant. Dose conversion factors used in the AIRDOS computer code" to estimate doses resulting from immersion in the airborne effluent, exposure to contaminated ground surface, and intake of radionuclides into the body through inhalation and ingestion are calculated with computer codes ${ }^{12,13}$ which use dosimetric criteria of the International Commission on Radiological Protection.

Estimates of the intake of radionuclides by man through terrestrial food chains are made with a model and computer code (TERMOD) ${ }^{+}$incorporated with AIRDOS, ${ }^{3}$ which considers transfers of all radionuclides to man via ingestion of crop plants, beef, and milk. Many basic environmental parameters used in this model are conservative; that is, values are chosen to maximize intake by man. Doses are calculated for the final period of plant operation when there is a 30-year accumulation of deposited radioactive materials on the ground surfaces outside the plant boundary. Reducing factors, such as shielding provided by dwellings and time spent away from the reference location specified in the calculation, are not considered. Moreover, in estimating the dose to individuals via ingestion of plants, beef, and milk, an individual is assumed to obtain all of his food at the reference location. This event is not impossible, but extremely unlikely. Thus, individual dose estimates calculated by these methods are higher than actually expected. Assumptions, models, and codes used to estimate radiation doses are given in ORNL-4992.'

Dose to individuals. The maximum annual total-body doses and organ doses to individuals from all airborne effluents at 1.5 miles from the model recycle $U F_{6}$ plant are summarized in Table 7.4 assuming that $100 \%$ of the food is produced locally. Appropriate dose reduction factors can be applied when the food production and consumption pattern are known. The average total-body doses to the individual at 1.5 miles from the plant are 55.5 and $66.7 \%$ of the maximum doses given for 1.5 miles (Table 7.4) for the midwestern and coastal sites, respectively.

The maximum doses to the individual at 0.5 mile from the plant are approximately 2.3 times those for the 1.5-mile distance shown in Table 7.4. Similarly, the maximum doses to the individual at 1 mile from the plant are approximately. 1.5 times those for the 1.5 -mile distance.

The maximum doses for the total body and organs at the midwestern site are slightly higher than the comparable doses at the coastal site (Table 7.4). In all cases, the annual doses at the 1.5-mile boundary were less than 1 millirem. The bone receives the highest organ dose, which is approximately nine times higher than the total-body dose. The doses to the lungs and kidney are, respectively, five and two times higher than the total-body dose at both sites. For organs not listed, the doses are equal to or less than those shown for the total-body doses. Radioactive waste treatment in Case 2 is effective in reducing the doses to the total body and organs to approximately one-half those for Case 1. For example, at the midwestern site the maximum annual total-body dose decreases from $6.1 \times 10^{-2}$ millirem in Case 1 to $2.5 \times 10^{-2}$ millirem in Case 2. Additional dose reduction to $1.2 \times 10^{-2}$ millirem is illustrated for Case 4 . 
Dose to population. The annual dose commitments from airborne effluents to the population living within 55 miles of the model plant are summarized in Table 7.5. Although the population around the midwestern site is over six times greater than that around the coastal site, the dose to the population (person-rem) is only 1.8 times greater for the midwestern site because of meteorological differences at the two sites. At the midwestern site the annual population total-body dose decreases from 1.4 person-rem in Case 1 to 0.55 person-rem in Case 2, and the population bone dose from 11.4 person-organ-rem to 4.5 person-organ-rem.

Exposure modes and radionuclides. The relative contributions of exposure modes to the total-body dose from airborne effluents are given in Table 7.6. Internal exposure from inhalation and ingestion accounts for more than $43 \%$ of the total-body dose, and exposure from contaminated ground surfaces accounts for essentially all of the remaining 57\%.

The relative contributions of the principal radionuclides to the individual doses from airborne effluents are presented in Table 7.7 and for the population in Table 7.8 (midwestern site) and Table 7.9 (southeastern coastal site). Almost 92\% of the maximum total-body dose of the individual is due to the uranium radionuclides, with ${ }^{232} \mathrm{U},{ }^{234} \mathrm{U}$, and ${ }^{238} \mathrm{U}$ accounting for more than $20 \%$ each and ${ }^{235} \mathrm{U}$ for almost $10 \%$. The exposure pathways of the radionuclides as shown in Table 7.10 indicate that the exposure to the total body from ${ }^{232} \mathrm{U},{ }^{235} \mathrm{U}$, and ${ }^{238} \mathrm{U}$ is primarily external, by way of contaminated ground surface, whereas the primary exposure mode of ${ }^{234} \mathrm{U}$ is by way of ingestion.

The major contributors to the organ doses (Table 7.7) are as follows: GI tract dose, ${ }^{94} \mathrm{Tc}$ $(26 \%)$, ${ }^{11 \%} \mathrm{Ru}(19 \%)$, and the uranium radionuclides $(52 \%)$; bone dose, uranium radionuclides $(76 \%)$ and ${ }^{23 \times} \mathrm{Pu}(12 \%)$; lung dose, uranium radionuclides $(98 \%)$; kidney dose, uranium radionuclides $(82 \%)$ and ${ }^{23 \times} \mathrm{Pu}(5 \%)$. The contributions to organ dose of inhaled and ingested radionuclides are presented in Table 7.11 .

7.3.2 Postoperational exposure from long-lived radionuclides released into the environment from a recycle $U F_{6}$ plant

Potential releases of radionuclides during plant operations and estimations of resulting radiation doses to individuals and populations are discussed in Sect. 7.3. In this section, estimates are presented of future potential radiation doses to individuals and populations exposed to the long-lived radionuclides that are deposited on the land surface as a result of plant operation. The estimates involve many complex considerations. All of the information necessary to make accurate predictions is not available. In the absence of complete information, estimates are made using the best current knowledge. Conservative assumptions are made in areas where deficiencies of knowledge exist. These assumptions make it likely that the estimates of health consequence are well above the probable effects.

Postoperational source terms. The model recycle UF, plant (Case 1) releases a total of $0.17 \mathrm{Ci}$ of radionuclides per year of operation in the airborne effluent. During this time, individuals and populations are exposed to an airborne radioactive cloud from which they receive radiation doses due to immersion in the cloud and inhalation. At the same time, 
radionuclides deposited on the ground surface from the cloud lead to exposures from contaminated ground and ingestion of contaminated food.

During the lifetime of the plant, radionuclides are deposited and accumulate in the environment around the plant. The radionuclides with long half-lives continue to be a source of exposure to people long after the plant has ceased operation. Table 7.12 lists these radionuclides and the total quantities released from the model UF, facility during its 30 years of operation. Except for ${ }^{23} \mathrm{U}$ and ${ }^{\prime \prime} \mathrm{Pu}$. the radionuclides listed will remain in the environment for generations.

The distribution of these radionuclides around the plant must be estimated in order to define the radiation dose to the population. For this assessment, it is estimated that essentially all of the radioactive elements are deposited in a 55-mile radius of the plant. Estimates of the deposition of particulates indicate that most of the materials are deposited within a 50-mile radius, even when the release point is the top of a 100 -m-high stack."

The average exposure to individuals and populations is estimated using the assumption that the radionuclides deposited during the operating lifetime of the model plant are uniformly distributed in the 55 -mile radius area $\left(2.46 \times 10^{10} \mathrm{~m}^{2}\right)$. The use of this assumption causes an underestimation of the dose to individuals living near the facility or in areas of the prevailing wind direction and an overestimation of the dose to individuals living in the outer annulus of the 55-mile radius of the plant.

Postoperational pathways of exposure. Pathways by which the deposited radionuclides may result in external and internal exposure to man are discussed below.

(a) Resuspended air activit:. After airborne particulates have been removed from the atmosphere and reach the ground by deposition and washout, they may reenter the atmosphere by resuspension processes. In this case. they may be inhaled. There is presently no general model which may be used to predict the levels of resuspended air activity with due regard to the geometrical configuration of the land surface, the particle characteristics of the deposited radioactivity, and the parameters of host soil, the vegetation cover, and the meteorological conditions. These highly variable factors and others related to land use, such as the disturbance of soil surfaces by human activity. must be considered in preparing a precise estimate of resuspended radioactivity.

A resuspension factor can be estimated from measurements made above aged contaminated soil and from consideration of natural tracers such as ${ }^{23 x} \mathrm{U}$. Resuspension factors of $10^{-9}$ and $10^{-111} \mathrm{~m}^{-1}$ were obtained from recent mcasurements of ${ }^{231} \mathrm{Pu}$ made at the Nevada Test Site in an area contaminated 17 years previously. ${ }^{i+}$ Measurements of ${ }^{23 \%} \mathrm{Pu}$ in the vicinity of the Rocky Flats Plant several years after deposition indicated a resuspension factor of $10^{-4} \mathrm{~m}^{-1} .{ }^{14}$ Discounting airborne material of industrial origin, it appears from the data concerning movement of naturally occurring $\therefore U$ that a realistic estimate of the resuspension of aged radioactive material in surface soil lies between $10^{\text {" }}$ and $10^{-11} \mathrm{~m}^{-1}$. . This is in agreement with the field measurements for ${ }^{2.39} \mathrm{Pu}$. An intermediate value of $1 \times 10^{-1} \mathrm{~m}^{-1}$ is used in this study to estimate the amounts of long-lived radionuclides inhaled over a long period of time for the relatively large well-vegetated regions around a recycle UF, facility. It is assumed that this value remains constant even though the deposited radionuclides may not remain on or near the surface of the soil. Actually, a continuation in the reduction of the availability of these materials beyond the current measurement experience of 20 years can be expected. Thus, the 
use of a constant resuspension factor is a conservative assumption which will maximize the estimated dose. Resuspended radionuclides are also assumed to enter terrestrial food pathways (vegetables, milk, and beef) via redeposition on the foliage of crops and pastures. For estimating intake via inhalation of resuspended radionuclides, the expression is:

$$
\text { Ci intake } \mathrm{yr}^{-1}=\mathrm{Ci} \mathrm{m}^{-2} \times 10^{-9} \times 7300 \mathrm{~m}^{3} \text { air inhaled } \mathrm{yr}^{-1}
$$

(b) Ingestion. The radionuclides that are not inhaled by man remain in the environment for periods proportional to their radiological half-lives. During this time, they may be ingested by man. Plants may be contaminated by direct deposition of airborne particles onto foliar parts and by root uptake of isotopes leached from or exchanged with particles deposited in soil. Plant uptake studies show that uranium, neptunium, and plutonium are strongly excluded from plant uptake and poorly translocated by plant systems.

The fraction of radionuclides that enters man during their long existence in the environment will depend on their distribution, their chemical and physical behavior in the environment for thousands of years, and climatological conditions and land use patterns specific to the area. Sufficiently detailed and accurate knowledge regarding the many factors influencing the movement of these elements through the environment over the periods of hundreds to tens of thousands of years during which they may enter man through the ingestion pathway is not available to permit a precise estimate of the dose to man. It is appropriate, therefore, to estimate potential human ingestion using conservative parameters and assumptions. In preparing the estimate for this study, it is assumed that plant material accumulates a concentration $\left(\mathrm{C}_{f}\right.$ value) of technetium equal to $2.5 \times 10^{-1}$, uranium equal to $2.5 \times 10^{-3}$, neptunium equal to $2.5 \times 10^{-3}$, and plutonium equal to $2.5 \times 10^{-4}$ of the concentration in the soil in which the plants grow, that there is no downward movement of the radionuclide in the soil beyond the root zone $(15 \mathrm{~cm})$, and that the radionuclide is not lost by drainage of water. With a soil density of $1.5 \mathrm{~g} \mathrm{~cm}^{-3}$, the radionuclides deposited on a square meter of earth are contained in $2.25 \times 10^{5} \mathrm{~g}$ of soil. The following expression is used to estimate the intake of radionuclides via ingestion of plants:

$$
\mathrm{Ci} \mathrm{yr}^{-1} \text { ingested }=\mathrm{Ci} \mathrm{m}^{-2} / 2.25 \times 10^{5} \mathrm{~g} \text { soil m}^{-2} \times \mathrm{C}_{f} \times 91,250 \mathrm{~g} \text { plant ingested } \mathrm{yr}^{-1} \text {. }
$$

Additional intake from the ingestion of plants contaminated via resuspended radionuclides is calculated using the TERMOD code. ${ }^{4}$

(c) Contaminated ground. Exposure via contaminated ground is also estimated. It is assumed that there is no loss of deposited radionuclides except through radioactive decay.

Estimates of postoperational doses. The radiation dose to an individual residing within the uniformly contaminated area of $9.5 \times 10^{3}$ square miles is estimated for total body and for the organs that are known to accumulate the long-lived radionuclides. The actual population living within a 55-mile radius of the midwestern plant site is used, and the population doses are expressed in terms of person-rems per 3.6 million persons.

All radiation doses from ingestion and inhalation are 50-year dose commitments from 1. year of exposure [i.e., the dose an individual will accrue over a 50-year period (essentially a lifetime dose) from 1 year of intake of radionuclides]. External doses (exposure to contaminated ground) are annual doses from 1 year of exposure. 
It is conservative to call a dose commitment an annual dose in the case of a single year's intake of long-lived radionuclides. However, for the purpose of assessing a situation where people are continually exposed over long periods of time and radionuclides have reached steady-state conditions in the environment, dose commitments approximate annual doses.

(a) Individual and organ doses. As a result of the deposition of long-lived radionuclides such as the actinides, persons living within a 55-mile radius of the recycle $U_{6}$ plant will continue to receive some radiation above background long after the plant has ceased operating, or actually until the ultimate decay of all the radionuclides. The average annual total-body doses to the individual out to 55 miles for the various radionuclides by exposure mode are shown in Table 7.13. Almost $95 \%$ of the total-body dose $\left(2.5 \times 10^{-4}\right.$ millirem in Case 1) results from exposure to the contaminated ground. Three of the uranium radionuclides, ${ }^{234} \mathrm{U},{ }^{235} \mathrm{U}$, and ${ }^{236} \mathrm{U}$, contribute more than $95 \%$ of the total-body dose. These doses are the average doses out to 55 miles. Under actual conditions of radionuclide dispersal, the dose range, as a function of distance, will vary considerably over the 55-mile area.

The average annual doses to the organs resulting from the various radionuclides and for the major internal pathways are shown in Table 7.14. The bone receives the highest dose $\left(1.4 \times 10^{-4}\right.$ millirem, Case 1$)$, which is more than three times the dose to the kidney and GI tract. The major contributors to the bone and kidney dose are ${ }^{234} \mathrm{U},{ }^{236} \mathrm{U}$, and ${ }^{238} \mathrm{U}$, while ${ }^{99} \mathrm{Tc}$ contributes about $79 \%$ of the GI tract dose.

(b) Population dose. The annual doses to the population, given as person-rem per 3.6 million persons, are presented in Table 7.15. The annual total-body dose ( 0.89 person-rem) is, as with the individual dose, due primarily to the ${ }^{2.34} \mathrm{U},{ }^{2.35} \mathrm{U}$, and ${ }^{236} \mathrm{U}$, which account for about $97 \%$ of the dose. The bone dose $(0.51$ person-organ-rem $)$ and the kidney dose $(0.14$ person-organ-rem) result primarily from ${ }^{234} \mathrm{U},{ }^{236} \mathrm{U}$, and ${ }^{238} \mathrm{U}$, while ${ }^{99} \mathrm{Tc}$ contributes about $80 \%$ of the GI tract dose (0.15 person-organ-rem).

\subsection{References}

1. G. G. Killough and L. R. McKay, (eds.), A Methodology for Calculating Radiation Doses from Radioactivity Released to the Environment, ORNL-4992 (March 1976).

2. Federal Radiation Council, Estimates and Evaluation of Fallout in the United States from Nuclear Weapons Testing Conducted through 1961, Report No. 4 (May 1963).

3. R. E. Moore, The AIRDOS-II Computer Code for Estimating Radiation Dose to Man from Airborne Radionuclides in Areas Surrounding Nuclear Facilities, ORNL-5245 (April 1977).

4. R. S. Booth, S. V. Kaye, and P. S. Rohwer, "A System Analysis Methodology for Predicting Dose to Man from a Radioactively Contaminated Terrestrial-Environment," Proceedings of the Third National Symposium on Radioecology, held in Oak Ridge, Tennessee, ed. by D. J. Nelson, CONF-710501, pp. 877-93.

5. F. Pasquill, Meteorol. Mag. 90, 1063 (1961). 
6. F. A. Gifford, Jr., "Use of Routine Meteorological Observations for Estimating Atmospheric Dispersion," Nucl. Safety 2(4), 47 (1961).

7. Since only limited joint frequency data are available for existing fuel fabrication and reprocessing sites, the model evaluation was based on the arbitrary selection of data from St. Louis, Mo,, and Wilmington, N. C., first-order records for midwestern and coastal environments, respectively. Joint frequency velocity and direction data by stability class were provided in the STAR tabulation format by the National Climatic Center, Asheville, N. C., for a 5-year period of record (St. Louis $1 / 65$ to $12 / 69$; Wilmington $1 / 66$ to $12 / 70)$.

8. F. A. Gifford, Jr., and D. H. Pack, "Surface Deposition of Airborne Material," Nucl. Safety 4(4), 76-80 (1962).

9. K. E. Cowser, M. Reeves, P. G. Fowler, and W. M. Culkowski, "Evaluation of the Potential Radiological Impact of Airborne Effluents on Local Environments," Proceedings of the International Symposium on Radioecology Applied to the Protection of Man and His Environment, EUR-4800 (September 1971).

10. D. H. Slade, Meteorology and Atomic Energy, TID-24190 (1968).

11. P. R. Coleman and A. A. Brooks, PANS: A Program to Tally Population by Annuli and Sectors, ORNL-TM-3923 (October 1972).

12. D. K. Trubey and S. V. Kaye, The EXREM III Computer Code for Estimating External Radiation Doses to Populations from Environmental Releases, OR NL-TM-4322 (December 1973).

13. W. D. Turner, S. V. Kaye, and P. S. Rohwer, EXREM and INREM Computer Codes for Estimating Radiation Doses to Populations from Construction of a Sea-Level Canal with Nuclear Explosives, K-1753 (Sept. 16, 1968).

14. Proposed Final Environmental Statement, Liquid Metal Fast Breeder Reactor Program, Vol. II, Environmental Impact of the LMFBR Fuel Cycle, USAEC, WASH-1535 (December 1974). 


\subsection{CORRELATION OF RADIOLOGICAL DOSE WITH COST OF WASTE TREATMENT}

The relationship between the annual costs of the radioactive waste treatment systems described in Sects. 4.0 and 6.0 and the radiological impact of radioactive releases (dose commitment) described in Sect. 7.0 is presented in this section. The accuracy of the cost estimates is about $\pm 30 \%$, and the dose commitments represent maximum values. The quantity of chemicals released by the model plant has been determined; however, the waste treatment systems have not been specifically designed to retain these substances, and the cost/benefit analysis does not address them.

Case 1, which is the base case, illustrates the important features of a facility which could be operated under present licensing regulations. Waste treatment systems are added to the basic plant primarily to remove radioactive materials from the gaseous effluents. In some instances, noxious chemicals such as $\mathrm{HF}, \mathrm{NO}_{x}$, and $\mathrm{SO}_{2}$ are also removed by the waste treatment systems (i.e., scrubbers using $\mathrm{KOH}$ solution). The advanced cases use technology which is not available for immediate use because it is still at the pilot-plant stage of development or because it is proprietary. Many of the models for the movement and concentration of radionuclides in the environment are receiving additional study to increase their accuracy. In all cases, the assumptions made in estimating the makeup of the feed to the plant, selecting the flows to the waste treatment system and treatment efficiency ratings for equipment, estimating costs, defining the movement of radionuclides in the environment, and selecting food and liquid consumption patterns were realistically conservative, and this conservatism is reflected in the costs and doses.

The annual costs and dose commitments for the base case (Case 1) and succeeding case studies (Cases 2 through 5) at the midwestern and coastal sites from airborne effluents are summarized in Table 8.1 and Figs. 8.1 and 8.2. The estimated annual costs required for additional airborne radioactive waste treatment in each case beyond that required for the previous case (i.e., the added incremental costs) are presented in Table 8.2. The dose commitments from the airborne effluents are reported on several bases, including (1) the maximum annual individual total-body, bone, lung, and kidney doses (other body organs which were discussed in Sect. 7.0, but which will not be considered here, include GI tract, thyroid, muscle, liver, spleen, testes, and ovaries) at 1.5 miles from the plant, which represent the doses from all radioactive materials released from the recycle facility in each case study; (2) incremental maximum annual individual doses at 1.5 miles, which represent the differences in dose between a given case and the preceding case; and (3) the annual dose to the population out to a distance of 55 miles. Factors for calculating maximum doses at distances other than 1.5 miles are given in Sect. 7.0. For example, the individual doses at 0.5 mile from the point of release are approximately 2.3 times greater than the doses at 1.5 miles. The maximum doses for a given annulus (downwind of the prevailing wind direction) are considered rather than the average individual doses to total body, bone, lung, and kidney, and the average population dose to illustrate the cost/benefit relationships in this section and thus maintain the principle of the selection of maximum effect in this study. Total-body dose was selected because of its obvious importance, and bone, lung, and kidney doses because the principal radionuclides that contribute to the total-body dose also contribute to these organ doses. 
Since liquids containing radioactivity of process origin are contained and isolated from the environment, the dose calculations are based only on the radioactive particulates released in the gaseous effluent from the plant. The calculated population doses for the midwestern site are slightly greater than those for the coastal site because of variations in atmospheric dispersion patterns and population densities. This difference, as applied to the annual population total-body dose, is shown in Table 8.1.

\subsection{Comparison of Airborne Radioactive Waste Treatment Costs and Radiological Dose}

The summary table (Table 8.1) is expanded into three separate tables (Tables 8.3-8.5) to identify the effectiveness of the individual waste treatment systems. The dust control effluent from the handling of dry materials contributes about $70 \%$ of the dose in the base case (Table 8.3), the process off-gas about $8 \%$ (Table 8.4 ), and the building ventilation about $21 \%$ (Table 8.5). The objectives in Case 2 are to reduce the quantity of material released with the dust control air by the addition of secondary bag filters. An $86 \%$ reduction in uranium release is obtained at a total annual cost of $\$ 96,000$. Case 3 includes additional treatment for both dust control and process off-gas streams. The total annual increase in cost of the effluent treatment system $(\$ 55,000)$ includes $\$ 29,500$ for a bank of HEPA filters for dust control and $\$ 25,400$ for a venturi scrubber on one of the process off-gas streams. Case 4 includes additional treatment equipment for all three sections of the effluent system with the following increases in annual cost over Case 3: dust control, $\$ 16,300$; process off-gas, $\$ 36,700$; and selected parts of the building ventilation, $\$ 114,000$. The final case study (Case 5) was selected to demonstrate the cost of a complete treatment system for the ventilation system (Case 5a) and a more effective method for isolation of solid waste containing radioactivity (Case $5 \mathrm{~b}$ ). The addition of bag filters to the ventilation air system is expensive because of the large volume of air to be treated. The total annual cost of the system is $\$ 617,000$ for Case $5 \mathrm{a}$. The total annual cost of incorporating the solid wastes in cement is $\$ 205,000$. Incorporation in cement provides an effective system for isolating wastes but does not decrease the dose from the model plant to the surrounding population.

\subsubsection{Individual total-body dose}

The maximum annual individual total-body dose is derived mostly from the uranium isotopes (about 92\%). The annual costs for reducing this dose from airborne effluents at 1.5 miles are presented in Tables 8.1-8.5 and in Fig. 8.1. The total-body dose is reduced by about $60 \%$ (i.e., from 0.061 to 0.025 millirem at the midwestern site and 0.055 to 0.022 millirem at the coastal site from Case 1 to Case 2) at a total annual cost increase of $\$ 96,000$. The cost/benefit ratio for this increment is $\$ 2.7$ million per millirem ( $\$ 2.9$ million per millirem at the coastal site), corresponding to an annual expenditure of about $0.5 \%$ of the $\$ 20$ million capital cost of the plant. The cost/benefit ratio increment increases from case to case (Table 8.2), with a final value of $\$ 51$ million for the Case 4/Case $5 \mathrm{a}$ increment for the 
midwestern site. This cost is further increased to $\$ 69$ million if the expense of incorporating the solid wastes in cement is included. The high cost/benefit ratios for the advance case increments result from the small incremental reductions in the removal of radioactive materials and small reductions in dose rather than from the magnitude of the treatment costs. The coastal site shows slightly lower doses and slightly higher cost/benefit ratios.

\subsubsection{Bone dose}

The maximum annual individual bone dose is derived from the uranium isotopes (76\%) and the plutonium isotopes (20\%). Annual costs to reduce the bone dose are presented in Tables 8.1-8.5 and in Fig. 8.1. The initial $60 \%$ reduction in dose achieved by the final treatment system between Cases 1 and 2 provides a cost/benefit ratio of $\$ 300,000$ per millirem at the midwestern site. Further reductions in the bone dose occur between the case studies with a resultant increase in the cost/benefit ratio. The cost/benefit ratio for the most expensive increment (Case $4 /$ Case $5 a$ ) is $\$ 5.6$ million per millirem for the midwestern site.

\subsubsection{Population dose}

The annual cost of reducing the annual total population total-body and bone doses (person-rem) out to a distance of 55 miles is presented in Tables 8.1-8.5 and in Fig. 8.2. The population dose values for Case 1 are low (i.e., 1.39 and 0.75 person-rem for total-body dose at the midwestern and coastal sites, respectively). These values are low when compared with the natural background radiation of $7.2 \times 10^{4}$ and $4.6 \times 10^{5}$ person-rem for the same populations. ${ }^{1,2}$ The addition of secondary bag filters on the dust control system reduces the population doses to 0.55 person-rem to the total body and 4.52 person-rem to the bone (11.4 person-rem in Case 1). The cost of this dose reduction from Case 1 to Case 2 is high $\$ 110,000 /$ person-rem total body and $\$ 14,000$ / person-rem bone for the general population out to 55 miles at the midwestern site (Table 8.2). Further dose reduction to very low levels using advanced technology is possible, but the incremental cost/benefit is very high (i.e., $\$ 1.4$ million/person-rem total body from Case 3 to Case 4 and $\$ 2.4$ million/person-rem total body between Cases 4 and $5 a$ ).

\subsubsection{Combined reprocessing - recycle UF, facility doses}

Finney et al. ${ }^{3}$ have correlated waste treatment costs and the environmental impact of a LWR fuel reprocessing plant which is expected to be located adjacent to the recycle $\mathrm{UF}_{6}$ facility. The annual population doses in the base case of the reprocessing plant at the midwestern site are as follows: total body, 1040 person-rem; GI tract, 2430 person-rem; bone, 1710 person-rem; and thyroid, 12,300 person-rem. By comparison with corresponding base case values for the recycle $U_{6}$ plant, namely $1.39,2.03,11.4$, and 1.40 person-rem, respectively, it is apparent that the dose commitment due to the recycle $U F_{6}$ plant is, in all cases, less than $1 \%$ of that due to reprocessing. 


\subsection{Comparison of Airborne Radioactive Waste Treatment Costs and Power Costs}

The capital cost of the total model plant for the base case (Case 1) is estimated at $\$ 20$ million, including the Case 1 off-gas treatment. The unit conversion cost is estimated at $\$ 4.85$ per $\mathrm{kg}$ of uranium for the base plant (Table 6.1). The capital costs for the airborne radioactive waste treatment in advanced cases range from $\$ 0.341$ to $\$ 3.59$ million, or up to about $18 \%$ of the capital cost of the base plant. The annual cost increases over the base case range from $\$ 0.096$ to $\$ 1.14$ million and are equivalent to contribution to power costs of 0.00026 to 0.0031 mill $/ \mathrm{kWhr}$, respectively. All of these values are less than $0.1 \%$ of an estimated total power generation cost of 7 to 10 mills/kWhr. Thus, the cost of airborne radioactive waste treatment is a small fraction of total capital and power generation costs.

\subsection{References}

1. P. C. Tompkins, "The Use and Misuse of Population Exposures in Radiation Protection," p. 9 in Population Exposure, held in Knoxville, Tennessee, October 21-24, 1974, CONF-741018 (October 1974).

2. A. W. Klement, Jr., C. R. Miller, R. P. Minx, and B. Shleien, Estimates of Ionizing Radiation Doses in the United States 1960-2000, ORP/CSD 72-1 (August 1972).

3. B. C. Finney, R. E. Blanco, R. C. Dahlman, G. S. Hill, F. G. Kitts, R. E. Moore, and J. P. Witherspoon, Correlation of Radioactive Waste Treatment Costs and the Environmental Impact of Waste Effluents in the Nuclear Fuel Cycle - Reprocessing Light Water Reactor Fuels, ORNL/NUREG/TM-6 (first revision of ORNL/TM-4901)(June 1976). 


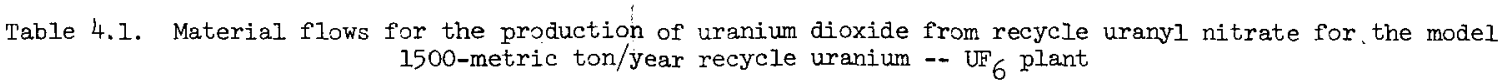
(Process streams are identified in Fig. 4.1)

\begin{tabular}{|c|c|c|c|c|c|c|c|c|c|c|c|c|c|c|c|c|}
\hline \multirow[b]{2}{*}{$\begin{array}{l}\text { Case } \\
\text { No. }\end{array}$} & \multirow{2}{*}{\multicolumn{2}{|c|}{ Code Type }} & \multirow{2}{*}{$\frac{\text { Stream }}{\text { Description }}$} & \multicolumn{3}{|c|}{$\begin{array}{c}\text { Gas flow } \\
\text { [1iters/day or }(\mathrm{scf} / \mathrm{day})]\end{array}$} & \multirow{2}{*}{$\begin{array}{c}\text { Liquida } \\
\text { flow } \\
{[1 \mathrm{tins} / \mathrm{day}} \\
\text { or }(\mathrm{gall} / \mathrm{dav})] \\
\end{array}$} & \multicolumn{6}{|c|}{ Flow rate $[\mathrm{kg} /$ day or $(1 \mathrm{~b} /$ day $)]$} & \multirow[b]{2}{*}{$\mathrm{SO}_{2}$} & \multirow[b]{2}{*}{$\mathrm{x}^{+}$} & \multirow[b]{2}{*}{$\mathrm{OH}^{-}$} \\
\hline & & & & Total & $\mathrm{N}_{2}$ & $\mathrm{O}_{2} \quad \mathrm{o}$ & & u & $\mathrm{H}^{+}$ & $\mathrm{NO}_{3}^{-}$ & $\mathrm{H}_{2} \mathrm{O}$ & $\mathrm{N}_{2} \mathrm{O}_{4}$ & $\mathrm{NH}_{3}$ & & & \\
\hline $1-5$ & A & Li quid & $\begin{array}{l}\text { Initial feed solution from } \\
\text { reprocessing plant }\end{array}$ & - & - & - & $\begin{array}{l}1.43 \mathrm{E}+4 \\
(3.77 \mathrm{E}+3)\end{array}$ & $\begin{array}{l}5.00 \mathrm{E}+3 \\
(1.10 \mathrm{E}+4)\end{array}$ & $\begin{array}{l}5.80 E-1 \\
(1.28 E+0)\end{array}$ & $\begin{array}{l}2.64 \mathrm{E}+3 \\
(5.82 \mathrm{~B}+3)\end{array}$ & $(2.27 \mathrm{E}+4)$ & - & - & - & - & - \\
\hline $1-5$ & B & Gaseous & $\begin{array}{l}\text { Sparging gas streams from } \\
\text { storage and accountability } \\
\text { feed tanks }\end{array}$ & $\begin{array}{l}1.47 \mathrm{E}+7 \\
(5.19 \mathrm{E}+5)\end{array}$ & $\begin{array}{l}1.128+7 \\
(3.94+5)\end{array}$ & $\begin{array}{l}3.00 \mathrm{E}+6 \\
(1.06 \mathrm{E}+5)\end{array}$ & - & - & $\begin{array}{l}5.22 E-4 \\
(1.15 E-3)\end{array}$ & $\begin{array}{l}3.24 \mathrm{~B}-2 \\
(7.13 \mathrm{~B}-2)\end{array}$ & $\begin{array}{c}3.28 \mathrm{E}+2 \\
(7.23 \mathrm{E}+2)\end{array}$ & - & - & - & - & - \\
\hline $1-5$ & c & Gaseous & Effluent from evaporator & $\left(\begin{array}{ll}\frac{1}{4} \cdot 30 \mathrm{E}+7 \\
(4.59 \mathrm{E}+5)\end{array}\right.$ & - & - & -. & - & $\begin{array}{l}5.72 E-1 \\
(1.26 E+0)\end{array}$ & $\begin{array}{l}3.54 \mathrm{E}+1 \\
(7.82 \mathrm{E}+1)\end{array}$ & $\begin{array}{l}1.04 \mathrm{E}+4 \\
(2.29 \mathrm{E}+4)\end{array}$ & - & - & - & - & - \\
\hline $1-5$ & D & Liquia & Condensate from evaporator & - & - & - & $\begin{array}{l}1.03 E+4 \\
(2.72 \mathrm{E}+3)\end{array}$ & - & $\begin{array}{l}5.72 \mathrm{E}-1 \\
(1.26 \mathrm{E}+0)\end{array}$ & $\begin{array}{c}3.548+1 \\
(7.828+1)\end{array}$ & $\begin{array}{l}1.03 \mathrm{E}+4 \\
(2.27 \mathrm{E}+4)\end{array}$ & - & - & - & - & - \\
\hline $1-5$ & E & Gaseous & $\begin{array}{l}\text { Sparging gas streans from } \\
\text { the condensate storaze } \\
\text { tanks }\end{array}$ & $\begin{array}{l}8.46 \mathrm{E}+6 \\
(2.99 \mathrm{E}+5)\end{array}$ & $\begin{array}{l}6.37 \%+6 \\
(2.25+5+5)\end{array}$ & $\begin{array}{l}\frac{1 .}{.79 E+6}(6) \\
(6.04 E+4)\end{array}$ & - & - & $\begin{array}{l}\text { 1. } 49 \mathrm{E}-4 \\
(3.29 \mathrm{E}-4)\end{array}$ & $\begin{array}{l}9.248-3 \\
(2.04 E-2)\end{array}$ & 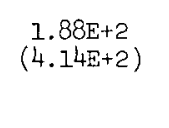 & $\frac{1.93 \mathrm{E}+1}{(4.25 \mathrm{E}+1)}$ & - & - & - & - \\
\hline $1-5$ & $\mathrm{~F}$ & Gaseous & Steam feed to denitrator & $\begin{array}{l}6.36 \mathrm{E}+6 \\
(2.25 \mathrm{E}+5)\end{array}$ & $\begin{array}{l}7.96 \mathrm{E}+5 \\
(2.81 \mathrm{E}+4)\end{array}$ & $\begin{array}{l}2.14 \mathrm{E}+5 \\
(7.54 \mathrm{E}+3)\end{array}$ & - & - & - & - & 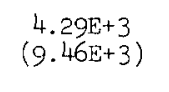 & - & - & - & - & - \\
\hline $1-5$ & a & Gaseous & $\begin{array}{l}\text { Efrluent stream from } \\
\text { denit trator }\end{array}$ & 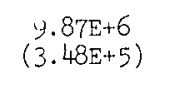 & $\begin{array}{l}7.96 \mathrm{E}+5 \\
(2.81 \mathrm{E}+4)\end{array}$ & $\begin{array}{l}4.49 \mathrm{E}+5 \\
(1.59 \mathrm{E}+4)\end{array}$ & - & - & - & - & $\begin{array}{l}6.54 E+3 \\
(1.44 E+4)\end{array}$ & 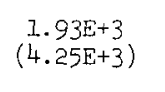 & - & - & - & - \\
\hline $1-5$ & H & Liquid & Condensate from denitrator & - & - & - & $\begin{array}{l}7.33 E+3 \\
(1.94 \mathrm{E}+3)\end{array}$ & - & $\begin{array}{l}4.16 \mathrm{P}+1 \\
(9.1 \mathrm{~T}+1)\end{array}$ & $\begin{array}{l}2.58 \mathrm{E}+3 \\
(5.69 \mathrm{E}+3)\end{array}$ & $\begin{array}{l}6.07 \mathrm{E}+3 \\
(1.34 \mathrm{E}+4)\end{array}$ & - & - & - & - & - \\
\hline 1 & I & Gaseous & $\begin{array}{l}\text { Effluent from feed prep- } \\
\text { aration and vacuum cleaner } \\
\text { maintenance system }\end{array}$ & $\begin{array}{l}2.16 \mathrm{E}+8 \\
(7.63 \mathrm{E}+6)\end{array}$ & $\begin{array}{l}1.69 \mathrm{E}+8 \\
(5.96 \mathrm{E}+6)\end{array}$ & $\begin{array}{l}4.53 E+7 \\
(1.60 E+6)\end{array}$ & - & $\begin{array}{l}9.69 \mathrm{E}-2 \\
(2.12 \mathrm{E}-1)\end{array}$ & - & - & $\begin{array}{l}2.14 E+1 \\
(4.72 E+1)\end{array}$ & - & - & - & - & - \\
\hline 2 & I & Gaseous & $\begin{array}{l}\text { Effluent from feed prep- } \\
\text { aration and vacuum cleaner } \\
\text { maintenance system }\end{array}$ & $\begin{array}{l}2.16 \mathrm{E}+8 \\
(7.63 \mathrm{E}+6)\end{array}$ & $\begin{array}{l}1.69 \mathrm{E}+8 \\
(5.96 \mathrm{E}+6)\end{array}$ & $\begin{array}{c}4.535+7 \\
(1.60 \mathrm{E}+6)\end{array}$ & - & $\begin{array}{l}(1.368-2 \\
(2.998-2)\end{array}$ & - & - & $\begin{array}{l}2.14 \mathrm{E}+1 \\
(4.72 \mathrm{E}+1)\end{array}$ & - & - & - & - & - \\
\hline $3-5$ & I & Gaseous & $\begin{array}{l}\text { Efrluent from feed prep- } \\
\text { aration and vacuum cleaener } \\
\text { maintenance system }\end{array}$ & $\begin{array}{l}2.16 \mathrm{E}+8 \\
(7.63 \mathrm{E}+6)\end{array}$ & $\begin{array}{l}1.69 \mathrm{E}+8 \\
(5.96 \mathrm{E}+6)\end{array}$ & $\begin{array}{l}4.53 \mathrm{E}+7 \\
(1.60 \mathrm{E}+6)\end{array}$ & - & $\begin{array}{l}6.788-6 \\
(1.498-5)\end{array}$ & - & - & $\begin{array}{l}2.14 \mathrm{E}+1 \\
(4.72 \mathrm{E}+1)\end{array}$ & - & - & - & - & - \\
\hline $1-5$ & a & Gaseous & $\begin{array}{l}\text { Anmonia feed to dissociator } \\
\text { and reductor }\end{array}$ & $\begin{array}{l}6.98 \mathrm{E}+5 \\
(2.47 \mathrm{E}+4)\end{array}$ & - & - & - & - & - & - & - & - & $\begin{array}{l}5.29 \mathrm{E}+\frac{1}{2} \\
\left(1.17 \mathrm{E}+\frac{3}{3}\right)\end{array}$ & - & - & - \\
\hline $1-5$ & к & Soliâa & $\begin{array}{l}\mathrm{UO}_{2} \text { product to hydrofluori- } \\
\text { nator }\end{array}$ & - & - & - & - & $\begin{array}{l}5.00 \mathrm{E}+3 \\
(1.10 \mathrm{E}+4)\end{array}$ & - & - & - & - & - & - & - & - \\
\hline $1-3$ & $\mathrm{~L}$ & Gaseous & Effluent from reductor & $\begin{array}{l}2.76 \mathrm{E}+6 \\
(9.75 \mathrm{E}+4)\end{array}$ & $\begin{array}{l}1.54 \mathrm{E}+6 \\
(5.44 \mathrm{E}+4)\end{array}$ & 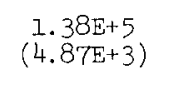 & - & $\begin{array}{l}5.00 \mathrm{E}-3 \\
(1.10 \mathrm{E}-2)\end{array}$ & - & - & $\begin{array}{l}8.39 E+2 \\
(1.85 E+3)\end{array}$ & - & - & $\begin{array}{l}2.99 \mathrm{E}+1 \\
(6.59 \mathrm{E}+1)\end{array}$ & - & - \\
\hline $4-5$ & I & Gaseous & Effluent from reductor & $\begin{array}{l}2.14 \mathrm{E}+6 \\
(7.56 \mathrm{E}+4)\end{array}$ & $\begin{array}{l}1.54 \mathrm{E}+6 \\
(5.44 \mathrm{E}+4)\end{array}$ & $\begin{array}{l}1.38 \mathrm{E}+5 \\
(4.87 \mathrm{E}+3)\end{array}$ & - & $\begin{array}{l}5.00 E-5 \\
(1.10 E-4)\end{array}$ & - & - & $\begin{array}{l}3.44 \mathrm{E}+2 \\
(7.58 \mathrm{E}+2)\end{array}$ & - & - & $\begin{array}{l}5.98 \mathrm{E}-1 \\
(1.32 \mathrm{E}+0)\end{array}$ & - & - \\
\hline 1 & M & Gaseous & $\begin{array}{l}\text { Combined effluent released } \\
\text { to the environment }\end{array}$ & $\begin{array}{l}2.42 E+8 \\
(8.55 \mathrm{E}+6)\end{array}$ & $\begin{array}{l}\frac{1.888+3}{(6.64 \mathrm{E}+6)} \\
-6)\end{array}$ & $\begin{array}{l}5.01 E+7 \\
(1.77 \mathrm{E}+6)\end{array}$ & - & $\begin{array}{l}1.02 \mathrm{E}-1 \\
(2.25 \mathrm{E}-1)\end{array}$ & $\begin{array}{l}6.71 E-4 \\
(1.48 E-3)\end{array}$ & $\begin{array}{l}4.16 \mathrm{~B}-2 \\
(9.17 \mathrm{~T}-2)\end{array}$ & $\begin{array}{l}1.38 \mathrm{E}+3 \\
(3.04 \mathrm{E}+3)\end{array}$ & $\begin{array}{l}\frac{1.938+1}{(4.25 \mathrm{E}+1)} \\
(1)\end{array}$ & - & $\begin{array}{l}2.99 \mathrm{E}+1 \\
(6.59 \mathrm{E}+1)\end{array}$ & - & - \\
\hline 2 & M & Gaseous & $\begin{array}{l}\text { Combined effluent released } \\
\text { to the environment. }\end{array}$ & $\begin{array}{l}2.42 E+8 \\
(8.55 E+6)\end{array}$ & 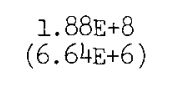 & $\begin{array}{l}5.01 \mathrm{E}+7 \\
(1.77 \mathrm{E}+6)\end{array}$ & - & $\left(\begin{array}{l}1.86 \mathrm{~B}-2 \\
(4.10 \mathrm{E}-2)\end{array}\right.$ & $\begin{array}{l}6.71 E-4 \\
(1.48 \mathrm{E}-3)\end{array}$ & $\begin{array}{l}4.16 \mathrm{~B}-2 \\
(9.17 \mathrm{~B}-2)\end{array}$ & $\begin{array}{l}1.38 \mathrm{E}+3 \\
(3.04 \mathrm{E}+3)\end{array}$ & 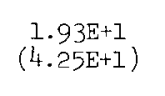 & - & $\cdot\left(\begin{array}{l}2.99 \mathrm{E}+1 \\
(6.59 \mathrm{E}+1)\end{array}\right.$ & - & - \\
\hline 3 & M & Gaseous & $\begin{array}{l}\text { Combined effluent released } \\
\text { to the environment }\end{array}$ & $\begin{array}{l}\begin{array}{l}2.42 E+8 \\
(8.55 E+6)\end{array}\end{array}$ & 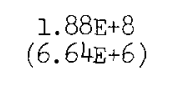 & $\begin{array}{l}5.01 E+7 \\
(1.77 \mathrm{E}+6)\end{array}$ & - & $\begin{array}{l}5.018-3 \\
(1.10 \mathrm{E}-2)\end{array}$ & $\begin{array}{l}6.71 E-4 \\
(1.48 E-3)\end{array}$ & $\begin{array}{l}4.16 \mathrm{E}-2 \\
(9.17 \mathrm{E}-2)\end{array}$ & $\begin{array}{l}\frac{1}{3} .38 \mathrm{E}+3 \\
(3.04 \mathrm{E}+3)\end{array}$ & $\frac{1.93 \mathrm{E}+1}{(4.25 \mathrm{E}+1)}$ & - & $\begin{array}{l}2.99 \mathrm{E}+1 \\
(6.59 \mathrm{E}+1)\end{array}$ & - & - \\
\hline $4-5$ & M & Gaseous & $\begin{array}{l}\text { Combined effluent released } \\
\text { to the environment }\end{array}$ & $\begin{array}{l}2.41 \mathrm{E}+8 \\
(8.52 \mathrm{E}+6)\end{array}$ & $\frac{1.88 \mathrm{E}+8}{(6.64 \mathrm{E}+6)}$ & $\begin{array}{l}5.01 \mathrm{E}+7 \\
(1.77 \mathrm{E}+6)\end{array}$ & - & $\begin{array}{l}5.68 \mathrm{E}-5 \\
(1.25 \mathrm{E}-4)\end{array}$ & $\begin{array}{l}6.71 E-4 \\
(1.48 E-3)\end{array}$ & $\begin{array}{l}4.16 \mathrm{E}-2 \\
(9.17 \mathrm{E}-2)\end{array}$ & $\begin{array}{l}8.81 E+2 \\
(1.94 \mathrm{E}+3)\end{array}$ & $\frac{1.93 \mathrm{E}+1}{(4.25 \mathrm{~B}+1)}$ & - & $\begin{array}{l}5.98 \mathrm{E}-1 \\
(1.32 \mathrm{E}+0)\end{array}$ & - & - \\
\hline $4-5$ & N & Liquid & $\begin{array}{l}\text { KoH feed stream to venturi } \\
\text { scrubber }\end{array}$ & - & - & - & $\begin{array}{l}6.23 \mathrm{E}+2 \\
(1.65 \mathrm{E}+2)\end{array}$ & - & - & - & $\begin{array}{l}6.12 \mathrm{E}+2 \\
(1.35 \mathrm{E}+3)\end{array}$ & - & & - & $\begin{array}{l}4.74 E+1 \\
(1.05 E+2)\end{array}$ & $\begin{array}{l}2.06 \mathrm{E}+1 \\
(4.54 \mathrm{E}+1)\end{array}$ \\
\hline $4-5$ & 0 & Liquid & $\begin{array}{l}\text { Eefluent stream from venturi } \\
\text { scrubber }\end{array}$ & - & - & - & $\begin{array}{l}1.13 \mathrm{E}+3 \\
(2.98 \mathrm{E}+2)\end{array}$ & $\begin{array}{l}\begin{array}{l}4.958-3 \\
(1.098-2)\end{array}\end{array}$ & - & - & $\begin{array}{l}1.112+3+3 \\
(2.43 E+3)\end{array}$ & - & & $\begin{array}{l}2.93 E+1^{a} \\
(6.46 \mathrm{E}+1)\end{array}$ & $\begin{array}{l}4.74 E+1 \\
(1.05 E+2)\end{array}$ & $\begin{array}{l}5.05 E+0 \\
(1.11 E+1)\end{array}$ \\
\hline
\end{tabular}




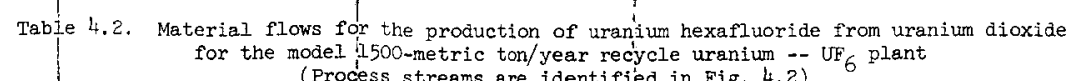

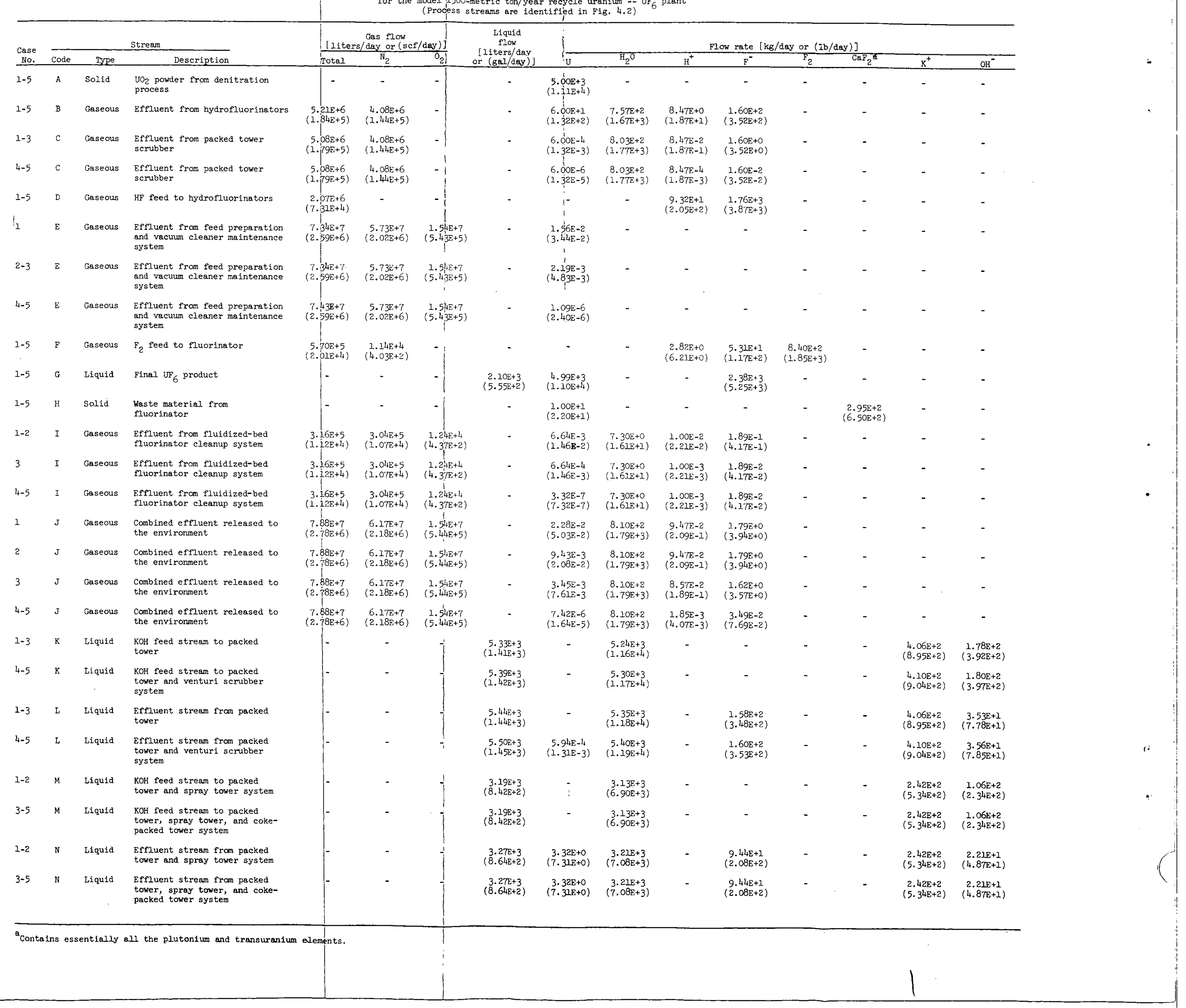




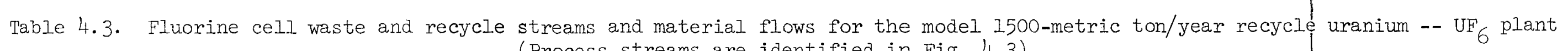
(Process streams are identified in Fig. 4.3)

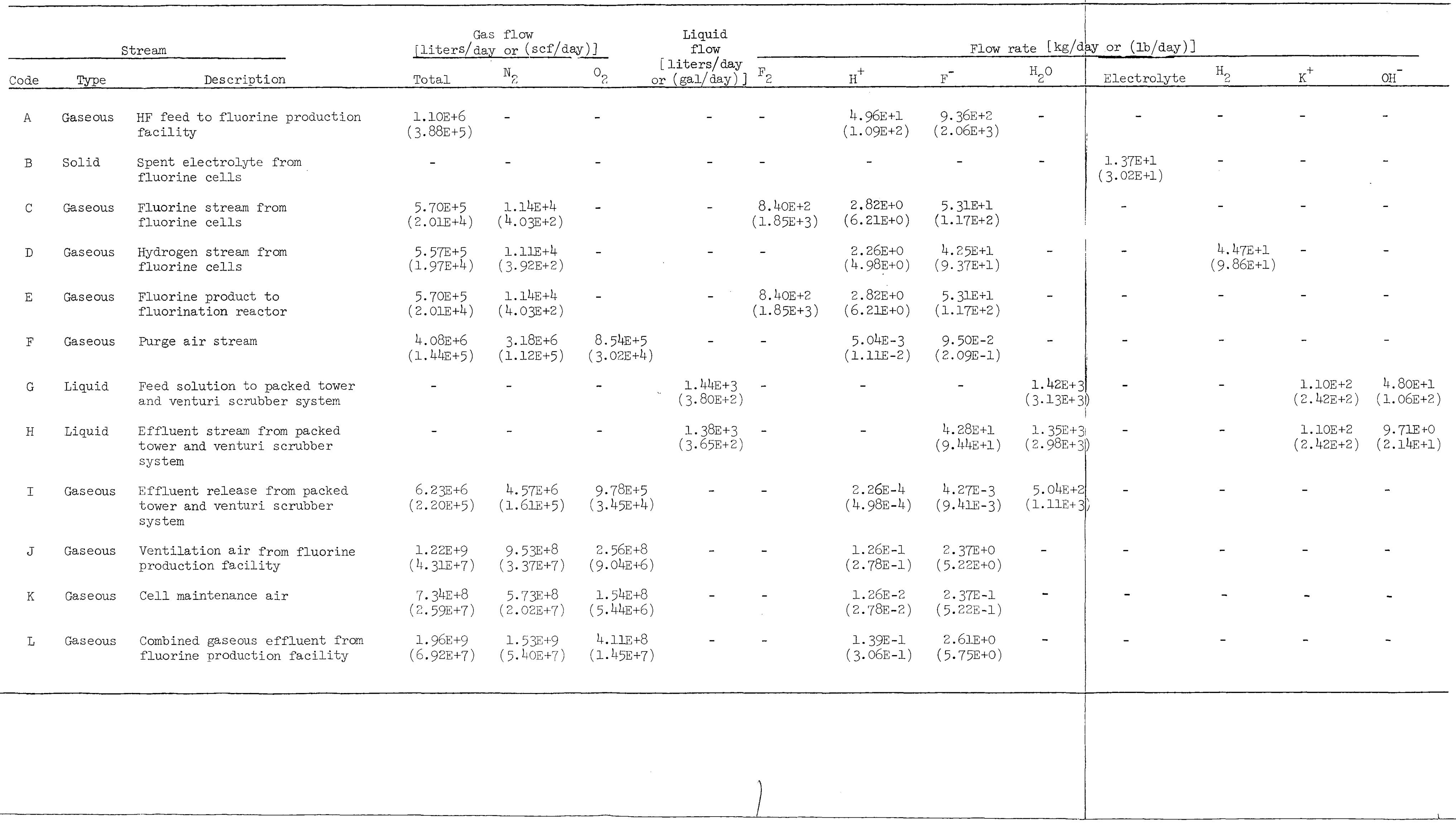




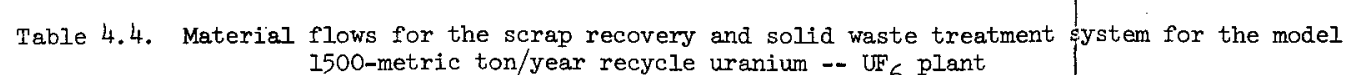

(Process strons are identified in Fig. 4.4)

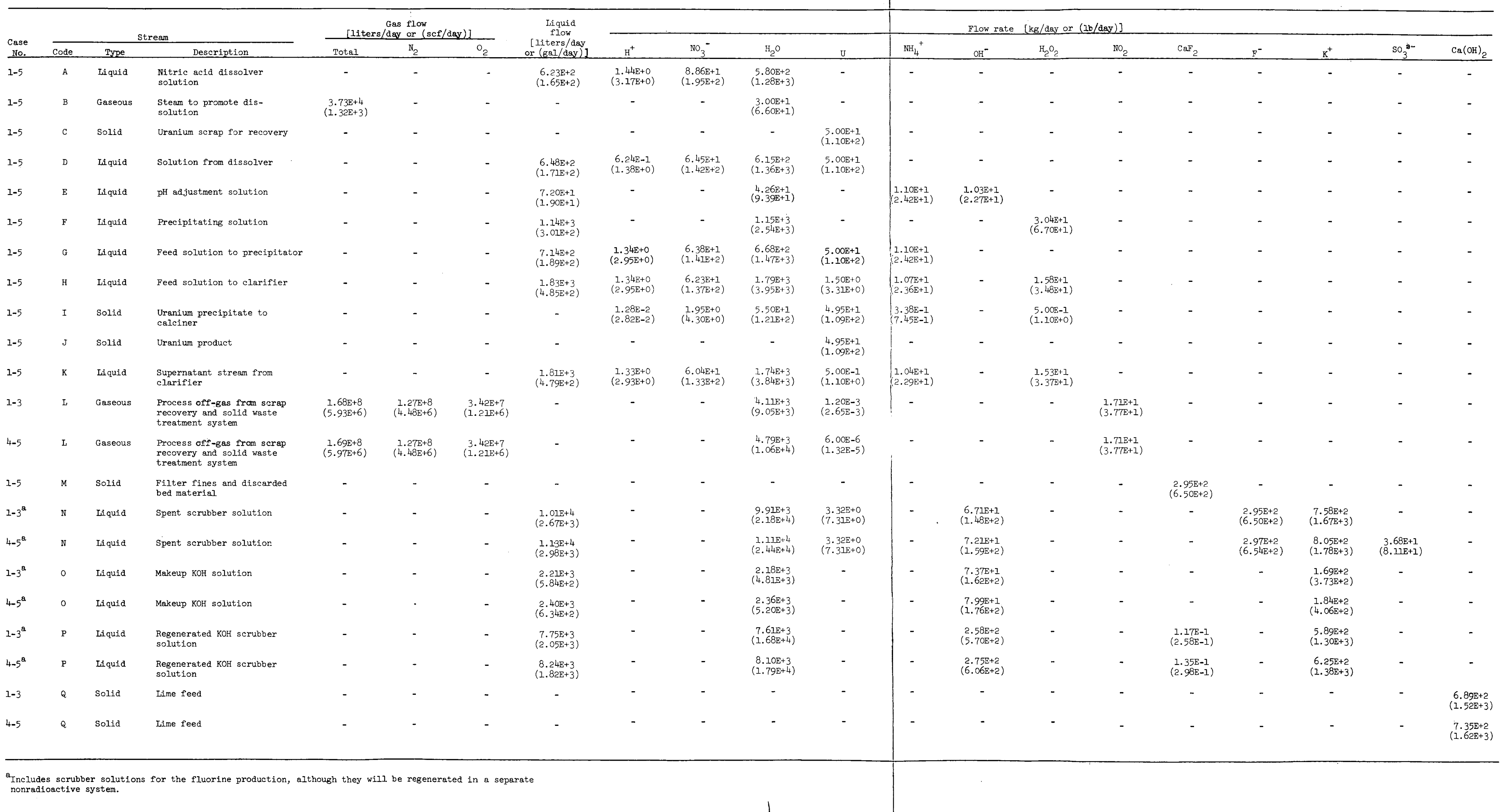


Table 4.5. Ventilation air flows for the model 1500-metric ton/year recycle uranium -- UF 6 plant (Process streams are identified in Fig. 4.6)

\begin{tabular}{|c|c|c|c|c|c|c|}
\hline \multirow[b]{2}{*}{ Case No. } & \multicolumn{2}{|r|}{ Stream } & \multicolumn{3}{|c|}{ Gas flow [liters/day or (scf/day)] } & \multirow{2}{*}{$\begin{array}{c}U \\
{[\mathrm{~kg} / \text { day or }} \\
(\mathrm{lb} / \text { day })]\end{array}$} \\
\hline & Code & Description & Total & $\mathrm{N}_{2}$ & $\mathrm{O}_{2}$ & \\
\hline $1-3$ & A & $\begin{array}{l}\text { Effluent from fluorination } \\
\text { and decontamination areas }\end{array}$ & $\begin{array}{l}6.12 \mathrm{E}+8 \\
(2.16 \mathrm{E}+7)\end{array}$ & $\begin{array}{l}4.78 \mathrm{E}+8 \\
(1.69 \mathrm{E}+7)\end{array}$ & $\begin{array}{l}1.28 \mathrm{E}+8 \\
(4.53 \mathrm{E}+6)\end{array}$ & $\begin{array}{l}4.00 \mathrm{E}-3 \\
(8.82 \mathrm{E}-3)\end{array}$ \\
\hline $4-5$ & A & $\begin{array}{l}\text { Effluent from fluorination } \\
\text { and decontamination areas }\end{array}$ & $\begin{array}{c}6.12 \mathrm{E}+8 \\
(2.16 \mathrm{E}+7)\end{array}$ & $\begin{array}{c}4.78 E+8 \\
(1.69 E+7)\end{array}$ & $\begin{array}{l}1.28 \mathrm{E}+8 \\
(4.53 \mathrm{E}+6)\end{array}$ & $\begin{array}{l}4.00 E-5 \\
(8.8=E-5)\end{array}$ \\
\hline $1-4$ & B & $\begin{array}{l}\text { Effluent from main process } \\
\text { ventilation area }\end{array}$ & $\begin{array}{l}4.89 E+9 \\
(1.73 E+8)\end{array}$ & $\begin{array}{c}3.82 \mathrm{E}+9 \\
(1.35 \mathrm{E}+8)\end{array}$ & $\begin{array}{l}1.02 E+9 \\
(3.62 E+7)\end{array}$ & $\begin{array}{l}3.00 \mathrm{E}-2 \\
(6.61 \mathrm{E}-?)\end{array}$ \\
\hline 5 & B & $\begin{array}{l}\text { Effluent from main process } \\
\text { ventilation area }\end{array}$ & $\begin{array}{c}4.89 \mathrm{E}+9 \\
(1.73 \mathrm{E}+8)\end{array}$ & $\begin{array}{c}3.82 E+9 \\
(1.35 E+8)\end{array}$ & $\begin{array}{l}1.02 E+9 \\
(3.62 E+7)\end{array}$ & $\begin{array}{l}3.00 \mathrm{E}-5 \\
(6.61 \mathrm{E}-5)\end{array}$ \\
\hline $1-5$ & C & $\begin{array}{l}\text { Effluent from process support } \\
\text { ventilation area }\end{array}$ & $\begin{array}{l}1.84 \mathrm{E}+9 \\
(6.5 \mathrm{OE}+7)\end{array}$ & $\begin{array}{c}1.44 \mathrm{E}+9 \\
(5.07 \mathrm{E}+7)\end{array}$ & $\begin{array}{c}3.85 \mathrm{E}+8 \\
(1.36 \mathrm{E}+7)\end{array}$ & $\left(\begin{array}{l}1.00 \mathrm{E}-4 \\
(\because .0 \mathrm{O}-4)\end{array}\right.$ \\
\hline $1-5$ & D & $\begin{array}{l}\text { Effluent from UF6 cylinder } \\
\text { charging section ventilation area }\end{array}$ & $\begin{array}{l}6.12 \mathrm{E}+8 \\
(2: 16 \mathrm{E}+7)\end{array}$ & $\begin{array}{c}4.78 \mathrm{E}+8 \\
(1.69 \mathrm{E}+7)\end{array}$ & $\begin{array}{l}1.28 E+8 \\
(4.53 E+6)\end{array}$ & - \\
\hline $1-5$ & E & $\begin{array}{l}\text { Effluent from cold trap } \\
\text { area ventilation air }\end{array}$ & $\begin{array}{l}2.45 \mathrm{E}+8 \\
(8.65 \mathrm{E}+6)\end{array}$ & $\begin{array}{l}1.91 E+8 \\
(6.76 E+6)\end{array}$ & $\begin{array}{l}5.13 E+7 \\
(1.81 E+6)\end{array}$ & - \\
\hline $1-4$ & $\mathrm{~F}$ & $\begin{array}{l}\text { Combined effluent from main } \\
\text { ventilation area }\end{array}$ & $\begin{array}{c}7.59 \mathrm{E}+9 \\
(2.68 \mathrm{E}+8)\end{array}$ & $\begin{array}{c}5.93 \mathrm{~F}+9 \\
(2.09 \mathrm{E}+8)\end{array}$ & $\begin{array}{c}1.58 \mathrm{E}+9 \\
(5.61 \mathrm{E}+7)\end{array}$ & $\left(\frac{3.01 \mathrm{E}-2}{6.64 \mathrm{E}-?)}\right.$ \\
\hline 5 & F & $\begin{array}{l}\text { Combined effluent from main } \\
\text { ventilation area }\end{array}$ & $\begin{array}{c}7.59 \mathrm{E}+9 \\
(2.68 \mathrm{E}+8)\end{array}$ & $\begin{array}{l}5.93 E+9 \\
(2.09 E+8)\end{array}$ & $\begin{array}{l}1.58 \mathrm{E}+9 \\
(5.61 \mathrm{E}+7)\end{array}$ & $\begin{array}{l}1.30 \mathrm{E}-4 \\
(-87 \mathrm{E}-4)\end{array}$ \\
\hline $1-5$ & G & $\begin{array}{l}\text { Effluent from fluorine } \\
\text { production building }\end{array}$ & $\begin{array}{l}1.22 E+9 \\
(4 \cdot 32 E+7)\end{array}$ & $\begin{array}{l}9 \cdot 53 \mathrm{E}+8 \\
(3 \cdot 36 \mathrm{E}+7)\end{array}$ & $\begin{array}{l}2.56 \mathrm{E}+8 \\
(9 \cdot 04 \overline{\mathrm{s}}+6)\end{array}$ & - \\
\hline $1-3$ & H & $\begin{array}{l}\text { Combined effluent from all } \\
\text { ventilation areas }\end{array}$ & $\begin{array}{l}8.20 E+9 \\
(3.90 E+8)\end{array}$ & $\begin{array}{l}6.41 \mathrm{E}+9 \\
(2.26 \mathrm{E}+8)\end{array}$ & $\begin{array}{l}1.71 E+9 \\
(6.03 E+7)\end{array}$ & $\begin{array}{l}3.41 E-2 \\
(7.5 ? E-2)\end{array}$ \\
\hline 4 & $\mathrm{H}$ & $\begin{array}{l}\text { Combined effluent from all } \\
\text { ventilation areas }\end{array}$ & $\begin{array}{c}8.20 \mathrm{E}+9 \\
(\varepsilon .90 \mathrm{E}+8)\end{array}$ & $\begin{array}{l}6.41 E+9 \\
(2.26 E+8)\end{array}$ & $\begin{array}{l}1.71 \mathrm{E}+9 \\
(6.03 \mathrm{E}+7)\end{array}$ & $\begin{array}{c}3.01 E-2 \\
(6.64 E-2)\end{array}$ \\
\hline 5 & H & $\begin{array}{l}\text { Combined effluent from all } \\
\text { ventilation areas }\end{array}$ & $\begin{array}{c}8.20 E+9 \\
(2.90 E+8)\end{array}$ & $\begin{array}{l}6.41 \mathrm{E}+9 \\
(2.26 \mathrm{E}+8)\end{array}$ & $\begin{array}{l}1.71 \mathrm{E}+9 \\
(6.03 E+7)\end{array}$ & $\begin{array}{l}1.70 E-4 \\
(3.75 E-4)\end{array}$ \\
\hline
\end{tabular}


Table 4,6. Characteristics of the radioactive materials in the feed to the model 1500 -metric ton/year recycle uranium -- $\mathrm{UF}_{6}$ plant

\begin{tabular}{|c|c|c|c|c|c|c|c|}
\hline Nuclide & Half-life ${ }^{a}$ & $\begin{array}{l}\text { Principal type } \\
\text { of decay }\end{array}$ & $\begin{array}{l}\text { Initial activity in } \text { feed }^{c} \\
\text { (Ci/metric ton) }\end{array}$ & Nuclide & Half-life & $\begin{array}{l}\text { Principal type } \\
\text { of decay }\end{array}$ & $\begin{array}{l}\text { Initial activity in feed } \\
(\mathrm{Ci} / \text { metric ton })\end{array}$ \\
\hline 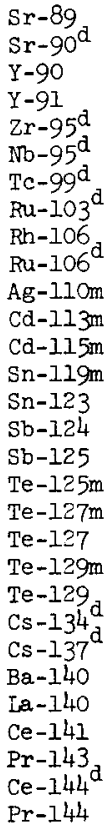 & 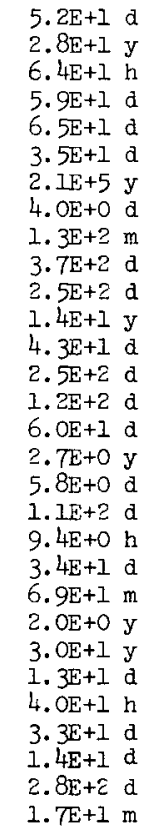 & $\begin{array}{l}\beta \\
\beta \\
\beta \\
\beta \\
\beta \\
\beta \\
\beta \\
\beta \\
\beta \\
\beta \\
\beta \\
\beta \\
\beta \\
I T \\
\beta \\
\beta \\
\beta \\
I T \\
I T \\
\beta \\
I T \\
\beta \\
\beta \\
\beta \\
\beta \\
\beta \\
\beta \\
\beta \\
\beta \\
\beta\end{array}$ & $\begin{array}{l}7.0 \mathrm{E}-4 \\
7.2 \mathrm{E}-4 \\
7.0 \mathrm{E}-4 \\
1.2 \mathrm{E}-3 \\
2.0 \mathrm{E}-2 \\
3.8 \mathrm{E}-2 \\
5.7 \mathrm{E}-1 \\
5.6 \mathrm{E}-3 \\
3.7 \mathrm{E}-2 \\
3.7 \mathrm{E}-2 \\
2.2 \mathrm{E}-5 \\
1.0 \mathrm{E}-7 \\
3.6 \mathrm{E}-7 \\
9.3 \mathrm{E}-8 \\
3.2 \mathrm{E}-5 \\
6.0 \mathrm{E}-7 \\
7.4 \mathrm{E}-5 \\
3.0 \mathrm{E}-5 \\
5.0 \mathrm{E}-5 \\
5.0 \mathrm{E}-5 \\
1.9 \mathrm{E}-5 \\
1.2 \mathrm{E}-5 \\
2.0 \mathrm{E}-3 \\
1.0 \mathrm{E}-3 \\
2.1 \mathrm{E}-6 \\
2.5 \mathrm{E}-6 \\
3.9 \mathrm{E}-4 \\
3.5 \mathrm{E}-6 \\
6.5 \mathrm{E}-3 \\
6.4 \mathrm{E}-3\end{array}$ & 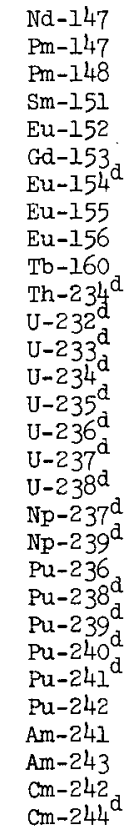 & $\begin{array}{l}1.1 \mathrm{E}+1 \mathrm{~d} \\
2.6 \mathrm{E}+0 \mathrm{y} \\
5.4 \mathrm{E}+0 \mathrm{~d} \\
8.7 \mathrm{E}+1 \mathrm{y} \\
1.2 \mathrm{E}+1 \mathrm{y} \\
2.4 \mathrm{E}+2 \mathrm{~d} \\
1.6 \mathrm{E}+1 \mathrm{y} \\
1.8 \mathrm{E}+0 \mathrm{y} \\
1.5 \mathrm{E}+0 \mathrm{~d} \\
7.2 \mathrm{E}+1 \mathrm{~d} \\
2.4 \mathrm{E}+1 \mathrm{~d} \\
7.2 \mathrm{E}+1 \mathrm{y} \\
1.6 \mathrm{E}+5 \mathrm{y} \\
2.5 \mathrm{E}+5 \mathrm{y} \\
7.1 \mathrm{E}+8 \mathrm{y} \\
2.4 \mathrm{E}+7 \mathrm{y} \\
6.8 \mathrm{E}+0 \mathrm{~d} \\
4.5 \mathrm{E}+9 \mathrm{y} \\
2.1 \mathrm{E}+6 \mathrm{y} \\
2.4 \mathrm{E}+0 \mathrm{~d} \\
2.8 \mathrm{E}+0 \mathrm{y} \\
8.6 \mathrm{E}+1 \mathrm{y} \\
2.4 \mathrm{E}+4 \mathrm{y} \\
6.6 \mathrm{E}+3 \mathrm{y} \\
1.3 \mathrm{E}+1 \mathrm{y} \\
3.8 \mathrm{E}+5 \mathrm{y} \\
4.6 \mathrm{E}+2 \mathrm{y} \\
7.9 \mathrm{E}+3 \mathrm{y} \\
1.6 \mathrm{E}+2 \mathrm{~d} \\
1.8 \mathrm{E}+1 \mathrm{y}\end{array}$ & $\begin{array}{l}\beta \\
\beta \\
\beta \\
\beta \\
E C \\
E C \\
\beta \\
\beta \\
\beta \\
\beta \\
\beta \\
\alpha \\
\alpha \\
\alpha \\
\alpha \\
\alpha \\
\beta \\
\alpha \\
\alpha \\
\beta \\
\alpha \\
\alpha \\
\alpha \\
\alpha \\
\beta \\
\alpha \\
\alpha \\
\alpha \\
\alpha \\
\alpha\end{array}$ & $\begin{array}{l}2.3 \mathrm{E}-7 \\
8.9 \mathrm{E}-4 \\
2.0 \mathrm{E}-6 \\
1.2 \mathrm{E}-5 \\
1.3 \mathrm{E}-7 \\
2.2 \mathrm{E}-7 \\
6.6 \mathrm{E}-5 \\
6.0 \mathrm{E}-5 \\
1.2 \mathrm{E}-6 \\
2.5 \mathrm{E}-6 \\
8.1 \mathrm{E}-2 \\
1.5 \mathrm{E}-2 \\
6.1 \mathrm{E}-5 \\
9.7 \mathrm{E}-1 \\
1.6 \mathrm{E}-2 \\
3.7 \mathrm{E}-1 \\
9.3 \mathrm{E}-1 \\
3.2 \mathrm{E}-1 \\
1.6 \mathrm{E}-3 \\
3.2 \mathrm{E}-3 \\
4.6 \mathrm{E}-7 \\
4.3 \mathrm{E}-3 \\
3.4 \mathrm{E}-4 \\
4.9 \mathrm{E}-4 \\
1.0 \mathrm{E}-1 \\
1.4 \mathrm{E}-6 \\
1.7 \mathrm{E}-6 \\
1.8 \mathrm{E}-7 \\
1.7 \mathrm{E}-4 \\
2.4 \mathrm{E}-5\end{array}$ \\
\hline
\end{tabular}

Values are taken from: C. M. Lederer, J. M. Hollander, and I. Perlman, Table of Isotopes, Sixth Edition, John Wiley \& Sons, New York, 1967.

Symbol definition: m-minute, h-hour, d-day, y-year.

${ }^{b}$ Symbol definition: $\alpha$-alpha, $\beta$-beta, IT-isomeric transition, EC-orbital electron capture.

${ }^{C}$ For assumptions concerning feed, see Sect. 4.2.

avuclides used in calculating source terms. 
Table 4.7. Specific activities and relative inhalation hazards of the major radioactive materials in the feed to the model 1500-metric ton/year recycle uranium -- UF 6 plant

\begin{tabular}{|c|c|c|}
\hline Nuclide & $\begin{array}{c}\text { Specific activity of } \\
\text { pure isotope } \\
(\mathrm{Ci} / \mathrm{g})\end{array}$ & $\begin{array}{c}\text { Contribution to the total } \\
\text { relative inhalation hazard } \\
(\%)\end{array}$ \\
\hline $\operatorname{Sr}-90$ & $1.4 \mathrm{E}+2$ & $<0.01$ \\
\hline $\mathrm{Zr}-95$ & $2.1 E+4$ & $<0.01$ \\
\hline $\mathrm{Nb}-95$ & $3.9 E+4$ & $<0.01$ \\
\hline Tc-99 & $1.7 E-2$ & 0.05 \\
\hline$R u-103$ & $3.2 E+5$ & $<0.01$ \\
\hline $\mathrm{Ru}-106$ & $1.4 E+7$ & 0.03 \\
\hline $\mathrm{Cs}-134$ & I. $3 E+3$ & $<0.01$ \\
\hline $\mathrm{Cs}-137$ & $8.7 \mathrm{E}+1$ & $<0.01$ \\
\hline $\mathrm{Ce}-154$ & $3.2 \mathrm{E}+3$ & $<0.01$ \\
\hline$E u-154$ & $1.4 \mathrm{E}+2$ & $<0.01$ \\
\hline$T h-234$ & 2. $3 E+4$ & 0.01 \\
\hline$U-232$ & 2. $.1 E+1$ & 2.75 \\
\hline $\mathrm{U}-233$ & $9.6 \vec{E}-3$ & $<0.01$ \\
\hline$U-234$ & $6.1 \mathrm{E}-3$ & 41.2 \\
\hline$U-235$ & $2.1 E-6$ & 0.68 \\
\hline$U-236$ & $6.3 E-5$ & 15.6 \\
\hline $\mathrm{U}-237$ & 8. $.1 E+4$ & -- \\
\hline U-238 & $3 \cdot 3 E-7$ & 18.3 \\
\hline $\mathrm{Np}-237$ & $7.2 \mathrm{E}-4$ & 2.70 \\
\hline $\mathrm{Np}-239$ & $2.3 E+5$ & $<0.01$ \\
\hline$P u-238$ & $1.7 \mathrm{E}+1$ & 10.4 \\
\hline$P u-239$ & $6.2 E-2$ & 0.95 \\
\hline$P u-240$ & $2.3 E-1$ & 1.39 \\
\hline$P u-24 I$ & 1. $1 \mathrm{E}+2$ & 5.93 \\
\hline $\mathrm{Cm}-244$ & $8.1 E+1$ & 0.01 \\
\hline
\end{tabular}

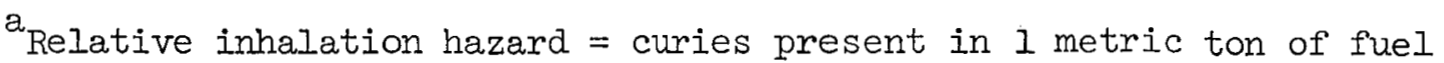
divided by the Radiation Concentration Guide value. 
Table 4.8. Airborne radioactive waste treatment variables for the model 1500-metric ton/year recycle uranium -- UF 6 plant

\begin{tabular}{|c|c|c|c|c|c|c|}
\hline Source & $\begin{array}{l}\text { Principal } \\
\text { contaminant } \\
\text { removed }\end{array}$ & Case 1, base plant & Case 2 & Case 3 & Case 4 & Case 5 \\
\hline Evaporation and denitration & $\mathrm{HNO}_{3}, \mathrm{H}_{2} \mathrm{O}$ & Condenser system & Same as Case 1 & Same as Case 1 & Same as Case 1 & Same as Case 1 \\
\hline \multirow[t]{2}{*}{ Reduction } & Particulates & $\begin{array}{l}\text { Primary } 10-\mu \text { porous } \\
\text { stainless steel filter; } \\
\text { secondary } 10-\mu \text { porous } \\
\text { stainless steel filter }\end{array}$ & Same as Case I & Same as Case 1 & $\begin{array}{l}\text { Case I plus KOH } \\
\text { high-energy venturi } \\
\text { scrubber }\end{array}$ & Same as Case 4 \\
\hline & $\mathrm{H}_{2}, \mathrm{H}_{2} \mathrm{~S}$ & $\begin{array}{l}\text { Flame arrestor; } \mathrm{H}_{2}, \mathrm{H}_{2} \mathrm{~S} \\
\text { burner }\end{array}$ & Same as Case 1 & Same as Case 1 & $\begin{array}{l}\text { Case I plus KOH } \\
\text { high-energy venturi } \\
\text { scrubber }\end{array}$ & Same as Case 4 \\
\hline \multirow[t]{2}{*}{ Hydrof?uorination } & Particulates & $\begin{array}{l}\text { Primary porous metal } \\
\text { filter; secondary porous } \\
\text { metal filter }\end{array}$ & Same as Case 1 & Same as Case 1 & $\begin{array}{l}\text { Case I plus } \mathrm{KOH} \\
\text { high-energy venturi } \\
\text { scrubber }\end{array}$ & Same as Case 4 \\
\hline & $\mathrm{HF}$ & KOH packed tower & Same as Case 1 & Same as Case 1 & $\begin{array}{l}\text { Case } 1 \text { plus } \text { KOH } \\
\text { high-energy venturi } \\
\text { scrubber }\end{array}$ & Same as Case 4 \\
\hline \multirow[t]{3}{*}{ Fluorination } & Particulates & $\begin{array}{l}\text { Primary porous metal } \\
\text { filter; secondary porous } \\
\text { metal filter }\end{array}$ & Same as Case 1 & Same as Case 1 & $\begin{array}{l}\text { Case } 1 \text { plus HF- } \\
\text { resistant HEPA filter }\end{array}$ & Same as Case 4 \\
\hline & $\mathrm{UF}_{6}$ product & $\begin{array}{l}\text { Cold traps, } 0^{\circ} \mathrm{F} \text { and } \\
-50^{\circ} \mathrm{F}\end{array}$ & Same as Case 1 & Same as Case I & Same as Case 1 & Same as Case 1 \\
\hline & $\mathrm{UF}_{6}, \mathrm{~F}_{2}, \mathrm{HF}$ & $\begin{array}{l}\text { KOH spray tower and } \\
\text { packed tower system }\end{array}$ & Same as Case 1 & $\begin{array}{l}\text { Case I plus KOH coke- } \\
\text { packed tower }\end{array}$ & Same as Case 3 & Same as Case 3 \\
\hline $\begin{array}{l}\text { Vacuum cleaner and } \\
\text { feed preparation }\end{array}$ & Particulates & $\begin{array}{l}\text { Centrifugal separator; } \\
\text { cleaner bag; bag filter }\end{array}$ & $\begin{array}{l}\text { Case I plus secondary } \\
\text { bag filter }\end{array}$ & Same as Case 2 & $\begin{array}{l}\text { Case } 3 \text { plus HF- } \\
\text { resistant HEPA filter }\end{array}$ & Same as Case 4 \\
\hline $\begin{array}{l}\text { Scrap recovery and } \\
\text { ash handling system }\end{array}$ & Particulates & HEPA filter & Same as Case 1 & Same as Case I & $\begin{array}{l}\text { Case I plus secondary } \\
\text { HEPA filter }\end{array}$ & Same as Case 4 \\
\hline $\begin{array}{l}\text { Main plant ventilation } \\
\text { system }\end{array}$ & Particulates & No treatment & Same as Case 1 & Same as Case 1 & Same as Case 1 & Bag filter \\
\hline $\begin{array}{l}\text { Fluorination and } \\
\text { decontamination area } \\
\text { ventilation system }\end{array}$ & Particulates & $\begin{array}{l}\text { Primary HEPA filter; } \\
\text { secondary HEPA filter }\end{array}$ & Same as Case 1 & Same as Case I & $\begin{array}{l}\text { Case I plus bag } \\
\text { filter }\end{array}$ & Same as Case 4 \\
\hline $\begin{array}{l}\text { Fluorine cell hydrogen } \\
\text { off-gas }\end{array}$ & $\mathrm{HF}, \mathrm{H}_{2}$ & $\begin{array}{l}\text { Flame arrestor; burner, } \\
\text { KOH high-energy venturi } \\
\text { scrubber and packed tower } \\
\text { system }\end{array}$ & Same as Case 1 & Same as Case 1 & Same as Case I & Same as Case 1 \\
\hline
\end{tabular}


Table 4.9. Source terms for the model 1500 -metric ton/year recycle uranium -- UF 6 plant - calculated release of radioactive material in airborne effluents

\begin{tabular}{|c|c|c|c|c|c|c|c|c|c|c|}
\hline \multirow[b]{2}{*}{ Nuclide } & \multicolumn{2}{|l|}{ Case 1} & \multicolumn{2}{|l|}{ Case 2} & \multicolumn{2}{|c|}{ Case 3} & \multicolumn{2}{|c|}{ Case 4} & \multicolumn{2}{|l|}{ Case 5} \\
\hline & $\begin{array}{c}\text { Concentration } \\
(\mu \mathrm{Cl} / \mathrm{ml})\end{array}$ & $\begin{array}{l}\text { Amount } \\
\text { (Ci/yr) }\end{array}$ & $\begin{array}{c}\text { Concentration } \\
(\mu \mathrm{Ci} / \mathrm{ml})\end{array}$ & $\begin{array}{l}\text { Amount } \\
(\mathrm{Ci} / \mathrm{yr})\end{array}$ & $\begin{array}{c}\text { Concentration } \\
(\mu \mathrm{Ci} / \mathrm{ml})\end{array}$ & $\begin{array}{l}\text { Amount } \\
\text { ( } \mathrm{Cl} / \mathrm{yr})\end{array}$ & $\begin{array}{c}\text { Concentration } \\
(\mu \mathrm{Ci} / \mathrm{ml})\end{array}$ & $\begin{array}{l}\text { Amount } \\
(\mathrm{Ci} / \mathrm{yr})\end{array}$ & $\begin{array}{c}\text { Concentration } \\
(\mu \mathrm{Ci} / \mathrm{ml})\end{array}$ & $\begin{array}{l}\text { Amount } \\
(\mathrm{Ci} / \mathrm{yr})\end{array}$ \\
\hline $\mathrm{Sr}-90$ & $1.15-14$ & $3.5 E-5$ & $4.3 E-15$ & $1.4 \mathrm{E}-5$ & $2.9 \mathrm{E}-15$ & $9.5 \mathrm{E}-6$ & $2.0 E-15$ & $6.5 E-6$ & $1.6 \mathrm{E}-17$ & $5.2 E-8$ \\
\hline $2 r-95$ & $2.9 \mathrm{E}-13$ & $9.4 \pm-4$ & 1. $2 \mathrm{E}-13$ & 3. $7 \mathrm{E}-4$ & $8.4 \mathrm{E}-14$ & $2.6 \mathrm{E}-4$ & $5.5 E-14$ & 1. $8 E-4$ & $4.4 \mathrm{E}-16$ & $1.4 E-6$ \\
\hline $\mathrm{Nb}-95$ & $5.7 \mathrm{E}-13$ & $1.8 E-3$ & 2. $2 \mathrm{E}-13$ & $7.1 E-4$ & $1.5 \mathrm{E}-13$ & $4.9 E-4$ & 1.1E-13 & $3.4 E-4$ & $8.5 E-16$ & $2.7 \mathrm{E}-6$ \\
\hline TC-99 & $8.6 E-12$ & $2.8 E-2$ & $3.4 \mathrm{E}-12$ & $1.2 E-2$ & 2. $4 E-12$ & 7. $5 \mathrm{E}-3$ & $1.6 \mathrm{E}-12$ & $5.2 E-3$ & 1. $3 E-14$ & 4. $1 E-5$ \\
\hline $\mathrm{Ru}-103$ & $8.4 E-14$ & $2.7 E-4$ & $3 \cdot 3 E-24$ & $1.1 \mathrm{E}-4$ & $2.3 E-14$ & $7 \cdot 3 E-5$ & $1.6 \mathrm{E}-14$ & $5.0 E-5$ & 1. $3 E-16$ & $4.0 E-7$ \\
\hline$R u-106$ & $5.6 E-13$ & $1.8 \mathrm{E}-3$ & 2. $2 \mathrm{E}-13$ & $7.1 \mathrm{E}-4$ & 1. $5 \mathrm{E}-13$ & $4.9 \mathrm{E}-4$ & 1. $1 E-14$ & $3.4 \mathrm{E}-4$ & $8.5 E-16$ & 2. $7 \mathrm{E}-6$ \\
\hline $\mathrm{cs}-134$ & $2.9 E-1.4$ & $9.4 E-5$ & 1.2E-14 & 3. $7 E-5$ & 8.0E-15 & $2.6 \mathrm{E}-5$ & $5.5 \mathrm{E}-15$ & $1.8 \mathrm{E}-5$ & $4.4 E-17$ & 1. $4 E-7$ \\
\hline Cs -137 & $1.5 \mathrm{E}-14$ & $4.9 E-5$ & $6.1 E-15$ & $1.9 E-5$ & $4.2 \mathrm{E}-15$ & $1.3 E-5$ & $2.9 E-15$ & $9.2 \mathrm{E}-6$ & $2 \cdot 3 E-17$ & $7.4 E-8$ \\
\hline $\mathrm{Ce}-144$ & $9.7 \mathrm{E}-14$ & 3. $1 E-4$ & $3.8 \mathrm{E}-14$ & 1. $2 E-4$ & 2. $7 E-14$ & $8.5 E-5$ & 1. $8 \mathrm{E}-14$ & $5.9 E-5$ & $1.5 \mathrm{E}-16$ & $4.7 \mathrm{E}-7$ \\
\hline Eu-J.54 & 1. OE -15 & $3.2 \mathrm{E}-6$ & $3.98-16$ & $1.3 E-6$ & 2.7E-16 & $8.7 \mathrm{E}-7$ & 1.9E-16 & $6.0 E-7$ & I. $5 E-18$ & $4.8 \mathrm{E}-9$ \\
\hline Th-234 & $1.2 \mathrm{E}-12$ & $3.9 \mathrm{E}-3$ & 4. $8 \mathrm{E}-13$ & 1. $5 \mathrm{E}-3$ & 3. $3 E-13$ & 2. $2 \mathrm{E}-3$ & 2. $3 \mathrm{E}-13$ & $7.4 \mathrm{E}-4$ & $2.8 \mathrm{E}-15$ & $5.9 E-6$ \\
\hline $\mathrm{U}-232$ & 2. $2 E-13$ & $7.0 \mathrm{E}-4$ & 8. $7 E-14$ & $2.8 \mathrm{E}-4$ & 6.OE-14 & $1.9 E-4$ & $4.75-14$ & 1. $3 E-4$ & 3. $3 \mathrm{E}-16$ & $1.1 E-6$ \\
\hline U-233 & $9.2 E-16$ & $2.9 E-6$ & 3. $6 \mathrm{E}-16$ & $1.2 E-6$ & $2.5 \mathrm{E}-16$ & $8.0 E-7$ & 1. $7 \mathrm{E}-16$ & 5. $5 \mathrm{E}-7$ & $1.4 \mathrm{E}-18$ & $4.4 E-9$ \\
\hline $\mathrm{U}-234$ & $1.5 \mathrm{E}-12$ & $4.7 \mathrm{E}-2$ & $5.8 \mathrm{E}-12$ & 1. $8 \mathrm{E}-2$ & 4. $\mathrm{OE}-12$ & 1. $3 E-2$ & 2. $8 \mathrm{E}-12$ & $8.8 \mathrm{E}-3$ & $2.2 \mathrm{E}-14$ & $7.0 \mathrm{E}-5$ \\
\hline U-235 & $2.4 \mathrm{E}-13$ & $7.7 \mathrm{E}-4$ & $9.5 \mathrm{E}-14$ & $3.0 E-4$ & $6.6 \mathrm{E}-14$ & $2.1 E-4$ & $4.5 E-14$ & $1.5 E-4$ & $3.6 \mathrm{E}-16$ & 1. $2 \mathrm{E}-6$ \\
\hline$U-236$ & $5.5 E-12$ & $1.8 \mathrm{E}-2$ & 2.2E-12 & $7.0 \mathrm{E}-3$ & $1.5 \mathrm{E}-12$ & $4.8 \mathrm{E}-3$ & 1. OE-IZ & 3. $3 E-3$ & $8.3 \mathrm{i}-1.5$ & $2.6 \mathrm{E}-5$ \\
\hline U-237 & 1. $4 \mathrm{E}-11$ & $4.5 E-2$ & $5.5 \mathrm{E}-12$ & $1.8 \mathrm{E}-2$ & $3.8 \mathrm{E}-12$ & 1. $2 \mathrm{E}-2$ & $2.6 \mathrm{E}-12$ & 8. $4 E-3$ & $2.1 E-14$ & $6.7 \mathrm{E}-5$ \\
\hline$U-238$ & $4.9 \mathrm{E}-12$ & 1. $6 \mathrm{E}-2$ & $1.9 \mathrm{E}-12$ & $6.2 \mathrm{E}-3$ & 1. $3 E-12$ & $4.3 E-3$ & $9.2 \mathrm{E}-13$ & $2.9 \mathrm{E}-3$ & $7 \cdot 3 B-15$ & 2. $3 E-5$ \\
\hline $\mathrm{Np}-237$ & 2. $4 \mathrm{E}-14$ & $7.6 \mathrm{E}-5$ & $9.5 E-15$ & $3.0 \mathrm{E}-5$ & $6.5 \mathrm{E}-15$ & 2.1E-5 & $4.5 E-15$ & 1. $4 \mathrm{E}-5$ & $3.6 \mathrm{E}-17$ & 1. $\mathrm{E}-7$ \\
\hline Np-239 & $4.9 E-14$ & $1.6 E-4$ & $1.9 \mathrm{E}-14$ & $6.1 E-5$ & 1. $35-14$ & $4.2 \mathrm{E}-5$ & 9.2E-15 & $2.9 E-5$ & $7 \cdot 3 E-17$ & $2.3 \mathrm{E}-7$ \\
\hline $\mathrm{Pu}-238$ & $6.5 \mathrm{E}-14$ & $2.1 E-4$ & $2.6 \mathrm{E}-14$ & $8.2 E-5$ & $1.8 \mathrm{E}-14$ & $5.6 E-5$ & $1.2 \mathrm{E}-14$ & $3.9 \mathrm{E}-5$ & $9 \cdot 7 \mathrm{E}-17$ & 3. $2 E-7$ \\
\hline Pu-239 & 5.1E-15 & 1. $6 \mathrm{E}-5$ & $2.0 \mathrm{E}-15$ & $6.4 \pm-6$ & $1.4 E-15$ & $4.4 E-6$ & $9.5 E-16$ & 3.0E-6 & $7.6 E-18$ & $2.4 E-8$ \\
\hline $\mathrm{Pu}-240$ & $7.4 \mathrm{E}-15$ & $2.4 E-5$ & $2.9 \mathrm{E}-15$ & $9 \cdot 3 E-6$ & 2.OE-15 & $6.58-6$ & 1. $4 \mathrm{E}-15$ & $4.5 E-6$ & $1.1 \mathrm{E}-17$ & $3 \cdot 5 E-8$ \\
\hline Pu-241 & $1.6 \mathrm{E}-12$ & $5.0 \mathrm{E}-3$ & $6.3 \mathrm{E}-13$ & 2. $0 \mathrm{E}-3$ & 4. $3 E-13$ & $1.4 E-3$ & $3.0 \mathrm{E}-13$ & $9.5 \mathrm{E}-4$ & $2.4 E-15$ & $7.6 \mathrm{E}-6$ \\
\hline $\mathrm{cm}-24 \overline{4}$ & 3. $7 \mathrm{E}-16$ & $1.2 \mathrm{E}-6$ & $1.5 \mathrm{E}-16$ & $4.7 E-7$ & 1. OE -16 & $3.2 E-7$ & $7.0 \mathrm{E}-17$ & 2. $2 \mathrm{E}-7$ & $5.5 \mathrm{E}-19$ & 1. $8 \mathrm{E}-9$ \\
\hline
\end{tabular}


Table 6.1. Estimated capital and annual costs and contribution to reprocessing and power costs for the model 1500-metric ton/year recycle uranium -- $\mathrm{UF}_{6}$ plant

\begin{tabular}{|c|c|c|c|c|c|c|}
\hline $\begin{array}{l}\text { Radwaste } \\
\text { treatment } \\
\text { case } \\
\end{array}$ & $\begin{array}{c}\text { Capital } \\
\text { costa }^{2} \\
(\$ 1000) \\
\end{array}$ & $\begin{array}{c}\text { Annual } \\
\text { fixed charges } \\
(\$ 1000)\end{array}$ & $\begin{array}{l}\text { Annual } \\
\text { operating cost } \\
(\$ 1000)\end{array}$ & $\begin{array}{c}\text { Total } \\
\text { annual cost } \\
(\$ 1000)\end{array}$ & $\begin{array}{l}\text { Conversion } \\
\text { coste } \\
\left(\begin{array}{ll}\$ / \mathrm{kg} & \mathrm{U}\end{array}\right) \\
\end{array}$ & $\begin{array}{c}\text { Contribution to } \\
\text { power cost } \\
\text { (mills/kwhr) }\end{array}$ \\
\hline \multicolumn{7}{|c|}{ Total cost - base plant } \\
\hline $1^{e}$ & 20,000 & 5,200 & 2,080 & 7,280 & 4.85 & 0.02 \\
\hline \multicolumn{7}{|c|}{ Additional cost for radwaste treatment systems } \\
\hline 2 & $\begin{array}{c}341 \\
(20,341)\end{array}$ & $\begin{array}{c}89 \\
(5,289)\end{array}$ & $\begin{array}{c}7 \\
(2,087)\end{array}$ & $\begin{array}{c}96 \\
(7,376)\end{array}$ & $\begin{array}{c}0.06 \\
(4.91)\end{array}$ & $\begin{array}{c}0.00026 \\
(0.02026)\end{array}$ \\
\hline 3 & $\begin{array}{c}540 \\
(20,540)\end{array}$ & $\begin{array}{c}140 \\
(5,340)\end{array}$ & $\begin{array}{c}11 \\
(2,091)\end{array}$ & $\begin{array}{c}151 \\
(7,431)\end{array}$ & $\begin{array}{c}0.10 \\
(4.95)\end{array}$ & $\begin{array}{c}0.00041 \\
(0.02041)\end{array}$ \\
\hline 4 & $\begin{array}{c}1,135 \\
(21,135)\end{array}$ & $\begin{array}{c}295 \\
(5,495)\end{array}$ & $\begin{array}{c}27 \\
(2,103)\end{array}$ & $\begin{array}{c}322 \\
(7,598)\end{array}$ & $\begin{array}{c}0.21 \\
(5.06)\end{array}$ & $\begin{array}{c}0.00086 \\
(0.02086)\end{array}$ \\
\hline $5 a$ & $\begin{array}{c}3,322 \\
(23,322)\end{array}$ & $\begin{array}{c}864 \\
(6,064)\end{array}$ & $\begin{array}{c}71 \\
(2,151)\end{array}$ & $\begin{array}{c}935 \\
(8,215)\end{array}$ & $\begin{array}{c}0.62 \\
(5.47)\end{array}$ & $\begin{array}{c}0.0025 \\
(0.0225)\end{array}$ \\
\hline $5 b$ & $\begin{array}{c}3,586 \\
(23,586)\end{array}$ & $\begin{array}{c}932 \\
(6,132)\end{array}$ & $\begin{array}{c}209 \\
(2,298)\end{array}$ & $\begin{array}{c}1,141 \\
(8,421)\end{array}$ & $\begin{array}{c}0.76 \\
(5.61)\end{array}$ & $\begin{array}{l}0.0031 \\
0.0231\end{array}$ \\
\hline
\end{tabular}

${ }^{a}$ System and structure capital cost consists of direct and indirectcosts. The interest during construction is included as an indirect cost.

${ }^{b}$ Annual operating costs are estimated at $40 \%$ of annual fixed charges, except for the venturi scrubbers and bag filters which are based on published information and on experience at ORNL for the HEPA filters. The annual costs of drums $(\$ 73,600)$ and cement $(\$ 47,300)$ for Case $5 \mathrm{~b}$ are included as additional annual operating costs. The annual cost of storing the drums onsite, burial onsite, or shipping offsite for storage or burial is not included.

The contribution to the conversion cost equals the annual cost divided by the $1.5 \times 10^{6} \mathrm{~kg}$ of uranium per year charged to the reactors.

The contribution to power cost is computed on the basis of a 1500 -metric ton/year recycle uranium UF 6 conversion plant servicing a nuclear economy of 32 1000-MW(e) PWRs (irradiation level, 33,000 MWd/metric ton; load factor, 80\%; thermal efficiency, 32.5\%) and 18 1000-MW(e) BWRs (irradiation level, 27,500 MWd/metric ton; load factor, 80\%; thermal efficiency, $35 \%)$. The costs include the direct charges but do not include the effect of carrying charges on fuel working capital.

${ }{ }$ Case 1 , the base case, represents a complete model recycle uranium conversion plant that produces UF $\mathrm{U}_{6}$ that is shipped to the enrichment plant. The 1973 capital cost of the plant is estimated at $\$ 20,000,000$. Radwaste treatment Cases $2-5 \mathrm{~b}$ are additions to the base case; consequently, the total capital cost for Cases $2-5 b$ would be $\$ 20,000,000$ plus the capital cost of the radwaste treatment case. The numbers in parentheses are total cost (i.e., base case plus added radwaste treatment cost). 
Table 6.2. Installed cost ${ }^{2}$ of equipment for model 1500-metric ton/year recycle uranium -- $\mathrm{UF}_{6}$ plant radwaste treatment: Cases $2-5 \mathrm{~b}$

\begin{tabular}{|c|c|c|c|}
\hline \multirow{2}{*}{$\begin{array}{l}\text { Radwaste } \\
\text { treatment } \\
\text { case } \\
\end{array}$} & & \multicolumn{2}{|c|}{$\begin{array}{c}\text { Costs without structures } \\
(\$ 1000)\end{array}$} \\
\hline & & Direct $^{b}$ & Capital ${ }^{c}$ \\
\hline \multirow[t]{2}{*}{2} & $\begin{array}{l}\text { Pulse jet bag filter, } 5300 \text { scfm } \\
\text { Pulse jet bag filter, } 1800 \text { scfm }\end{array}$ & $\begin{array}{l}89.3 \\
46.3 \\
\end{array}$ & $\begin{array}{l}214 \\
111 \\
\end{array}$ \\
\hline & & 135.6 & 325 \\
\hline \multirow[t]{2}{*}{3} & $\begin{array}{l}\text { Pulse jet bag filter, } 5300 \text { scfm } \\
\text { Pulse jet bag filter, } 1800 \text { scfm } \\
\text { HEPA filters, } 5300 \text { scfm } \\
\text { Coke-packed tower, } 8 \text { scfm }\end{array}$ & $\begin{array}{l}89.3 \\
46.3 \\
40.9 \\
36.0 \\
\end{array}$ & $\begin{array}{r}214 \\
111 \\
98 \\
86 \\
\end{array}$ \\
\hline & & 212.5 & 509 \\
\hline \multirow[t]{2}{*}{4} & $\begin{array}{l}\text { Pulse jet bag filter, } 5300 \mathrm{scfm} \\
\text { Pulse jet bag filter, } 1800 \mathrm{scfm} \\
\text { Pulse jet bag filter, } 15,000 \mathrm{scfm} \\
\text { Coke-packed tower, } 8 \mathrm{scfm} \\
\text { HEPA filters, } 5300 \mathrm{scfm} \\
\text { HEPA filters, } 1808 \text { scfm } \\
\text { HEPA filters, } 4000 \mathrm{scfm} \\
\text { High-energy venturi scrubber condenser, } 128 \mathrm{scfm} \\
\text { High-energy venturi scrubber condenser, } 68 \mathrm{scfm}\end{array}$ & $\begin{array}{r}89.3 \\
46.3 \\
166.0 \\
36.0 \\
40.9 \\
22.7 \\
34.4 \\
4.5 \\
3.1 \\
\end{array}$ & $\begin{array}{r}214 \\
111 \\
398 \\
86 \\
98 \\
54 \\
83 \\
11 \\
7 \\
\end{array}$ \\
\hline & & 443.2 & 1062 \\
\hline \multirow[t]{2}{*}{$5 a$} & $\begin{array}{l}\text { Pulse jet bag filter, } 5300 \text { scfm } \\
\text { Pulse jet bag filter, } 1800 \text { scfm } \\
\text { Pulse jet bag filter, } 15,000 \text { scfm } \\
\text { Pulse jet bag filter, } 60,000 \text { scfm } \\
\text { Coke-packed tower, } 8 \text { scfm } \\
\text { HEPA filters, } 5300 \text { scfm } \\
\text { HEPA filters, } 1808 \text { scfm } \\
\text { HEPA filters, } 4000 \mathrm{scfm} \\
\text { High-energy venturi scrubber condenser, } 128 \mathrm{scfm} \\
\text { High-energy venturi scrubber condenser, } 68 \mathrm{scfm}\end{array}$ & $\begin{array}{r}89.3 \\
46.3 \\
166.0 \\
911.0 \\
36.0 \\
40.9 \\
22.7 \\
34.4 \\
4.5 \\
3.1 \\
\end{array}$ & $\begin{array}{r}214 \\
111 \\
398 \\
2186 \\
86 \\
98 \\
54 \\
83 \\
11 \\
7 \\
\end{array}$ \\
\hline & & 1354.2 & 3248 \\
\hline \multirow[t]{2}{*}{$5 b$} & $\begin{array}{l}\text { Pulse jet bag filter, } 5300 \mathrm{scfm} \\
\text { Pulse jet bag filter, } 1800 \mathrm{scfm} \\
\text { Pulse jet bag filter, } 15,000 \mathrm{scfm} \\
\text { Pulse jet bag filter, } 60,000 \mathrm{scfm} \\
\text { Coke-packed tower, } 8 \mathrm{scfm} \\
\text { HEPA filters, } 5300 \mathrm{scfm} \\
\text { HEPA filters, } 1808 \mathrm{scfm} \\
\text { HEPA filters, } 4000 \mathrm{scfm} \\
\text { High-energy venturi scrubber condenser, } 128 \mathrm{scfm} \\
\text { High-energy venturi scrubber condenser, } 68 \mathrm{scfm} \\
\text { Cement plant }\end{array}$ & $\begin{array}{r}89.3 \\
46.3 \\
166.0 \\
911.0 \\
36.0 \\
40.9 \\
22.7 \\
34.4 \\
4.5 \\
3.1 \\
66.3 \\
\end{array}$ & $\begin{array}{r}214 \\
117 \\
398 \\
2186 \\
86 \\
98 \\
54 \\
83 \\
11 \\
7 \\
159 \\
\end{array}$ \\
\hline & & 1420.5 & 3407 \\
\hline
\end{tabular}

Details of the cost estimates are presented in Appendix A.

${ }^{b}$ Cost for 1973. Direct cost includes purchase cost and complete installation cost.

${ }^{c}$ Capital cost is calculated by multiplying the direct cost by 2.4. Capital cost includes direct cost and indirect cost. 
Table 7.1. Latitude-longitude coordinates used to derive data sets for population distribution ${ }^{a}$

\begin{tabular}{lll}
\hline Site & Latitude (N) & Longitude $(\mathrm{W})$ \\
\hline Midwestern & $35^{\circ} 52^{\prime} 50^{\prime \prime}$ & $97^{\circ} 35^{\prime}$ 0 \\
& $38^{\circ} 12^{\prime \prime} 18^{\prime \prime}$ & $90^{\circ} 28^{\prime} 28^{\prime \prime}$ \\
& $41^{\circ} 22^{\prime} 4^{\prime \prime}$ & $88^{\circ} 16^{\prime} 36^{\prime \prime}$ \\
Coastal & $33^{\circ} 15^{\prime} 00^{\prime \prime}$ & $81^{\circ} 29^{\prime} 20^{\prime \prime}$ \\
& $33^{\circ} 53^{\prime} 13^{\prime \prime}$ & $80^{\circ} 55^{\prime} 58^{\prime \prime}$ \\
& $34^{\circ} 19^{\prime} 19^{\prime \prime}$ & $77^{\circ} 56^{\prime} 12^{\prime \prime}$ \\
\hline
\end{tabular}

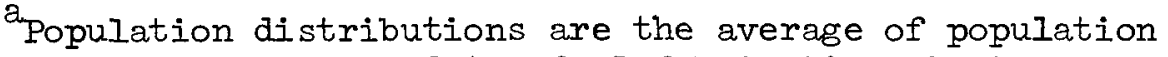
distributions around two fuel fabrication plants and one reprocessing plant. 
Table 7.2. Representative population distribution at successive distances for midwestern site

\begin{tabular}{|c|c|c|c|c|c|c|c|c|c|c|c|c|}
\hline \multirow[b]{2}{*}{ Sector } & \multicolumn{12}{|c|}{ Radial distance (miles) } \\
\hline & $0-0.5$ & $0.5-1$ & $1-2$ & $2-3$ & $3-4$ & $4-5$ & $5-10$ & $10-15$ & $15-25$ & $25-35$ & $35-45$ & $45-55$ \\
\hline $\mathrm{N}$ & 0 & 0 & 0 & 0 & 0 & 252 & 2,007 & 1,037 & 19,193 & 108,738 & 96,229 & 46,889 \\
\hline $\mathrm{NNE}$ & 0 & 0 & 0 & 0 & 0 & 816 & 847 & 7,688 & 40,643 & 347,330 & 300,030 & 300,804 \\
\hline NE & 0 & 0 & 0 & 0 & 0 & 709 & 936 & 23,608 & 22,601 & 77,981 & 625,661 & 575,054 \\
\hline ENE & 0 & 0 & 0 & 0 & 652 & 1,197 & 1,906 & 1,377 & 8,737 & 85,826 & 192,983 & 110,272 \\
\hline $\mathrm{E}$ & 0 & 0 & 0 & 365 & 0 & 452 & 3,506 & 254 & 1,824 & 10,629 & 14,875 & 24,482 \\
\hline ESE & 0 & 0 & 0 & 0 & 69 & 2 & 799 & 972 & 3,323 & 4,470 & $8,44+9$ & 4,378 \\
\hline $\mathrm{SE}$ & 0 & 0 & 0 & 13 & 537 & 482 & 1,022 & 696 & 3,241 & 23,827 & 5,080 & 15,453 \\
\hline SSE & 0 & 0 & 0 & 0 & 0 & 0 & 1,796 & 706 & 10,056 & 41,868 & 4,461 & 7,339 \\
\hline $\mathrm{s}$ & 0 & 0 & 0 & 87 & 0 & 72 & 1,498 & 908 & 30,234 & 100,668 & 10,935 & 17,328 \\
\hline SSW & 0 & 0 & 0 & 0 & 0 & 98 & 626 & 586 & 3,588 & 6,416 & $7,4,25$ & 3,933 \\
\hline SW & 0 & 0 & 146 & 0 & 0 & 0 & 2,233 & 428 & 2,614 & 6,862 & 1,717 & 3,257 \\
\hline WSW & 0 & 0 & 0 & 0 & 526 & 0 & 907 & 202 & 1,380 & 8,621 & 2,690 & 4,601 \\
\hline W & 0 & 0 & 0 & 0 & 0 & 0 & 3,128 & 655 & 4,400 & 8,192 & 14,438 & 8,317 \\
\hline WNW & 0 & 0 & 0 & 0 & 132 & 77 & 505 & 402 & 1,424 & 6,379 & 4,908 & 3,646 \\
\hline $\mathrm{NW}$ & 0 & 260 & 0 & 0 & 0 & 0 & 346 & 1,083 & 8,288 & 5,991 & 6,220 & 4,146 \\
\hline NNW & 0 & 0 & 0 & 0 & 544 & 0 & 579 & 829 & 5,823 & 5,027 & 28,615 & 20,359 \\
\hline $\begin{array}{l}\text { Total (by } \\
\text { distance }\end{array}$ & 0 & $\begin{array}{r}260 \\
\pm 449^{a}\end{array}$ & $\begin{array}{r}146 \\
\pm 220\end{array}$ & $\begin{array}{r}465 \\
+804\end{array}$ & $\begin{array}{r}2,460 \\
\pm 1,453\end{array}$ & $\begin{array}{r}4,157 \\
\pm 4,280\end{array}$ & $\begin{array}{l}22,641 \\
\pm 8,469\end{array}$ & $\begin{array}{r}40,498 \\
\pm 49,447\end{array}$ & $\begin{array}{l}167,369 \\
\pm 42,111\end{array}$ & $\begin{array}{r}848,825 \\
\pm 378,192\end{array}$ & $\begin{array}{r}1,324,696 \\
\pm 1,536,279\end{array}$ & $\begin{array}{r}1,150,618 \\
\pm 1,698,458\end{array}$ \\
\hline Cumulative & 0 & 260 & 406 & 871 & 3,331 & 7,488 & 30,129 & 70,627 & 237,996 & $1,086,821$ & $2,411,517$ & $3,562,135$ \\
\hline $\begin{array}{l}\text { Density } \\
\left.\text { (ind./mile }{ }^{2}\right)\end{array}$ & & & & & & & 96 & & & & 440 & $\longrightarrow$ \\
\hline
\end{tabular}

${ }^{a}$ Standard deviation of the mean (total). 
Table 7.3. Representative population distribution at successive distances for coastal plain site

\begin{tabular}{|c|c|c|c|c|c|c|c|c|c|c|c|c|}
\hline \multirow[b]{2}{*}{ Sector } & \multicolumn{12}{|c|}{ Radial distance (miles) } \\
\hline & $0-0.5$ & $0.5-1$ & $1-2$ & $2-3$ & $3-4$ & $4-5$ & $5-10$ & $10-15$ & $15-25$ & $25-35$ & $35-45$ & $45-55$ \\
\hline $\mathrm{N}$ & 0 & 0 & 0 & 151 & 0 & 46 & 10,358 & 7,761 & 3,512 & 4,060 & 4,835 & 9,942 \\
\hline NNE & 0 & 0 & 0 & 0 & 0 & 0 & 965 & 1,147 & 1,978 & 3,115 & 5,985 & 17,515 \\
\hline $\mathrm{NE}$ & 0 & 0 & 0 & 0 & 0 & 0 & 438 & 284 & 1,139 & 6,646 & 27,892 & 7,382 \\
\hline ENE & 0 & 0 & 0 & 0 & 443 & 0 & 847 & 1,119 & 4,112 & 6,321 & 12,413 & 9,022 \\
\hline E & 0 & 0 & 0 & 0 & 0 & 239 & 2,539 & 801 & 1,553 & 17,556 & 4,215 & 5,544 \\
\hline ESE & 0 & 0 & 0 & 0 & 0 & 0 & 1,726 & 420 & 660 & 2,463 & 4,700 & 6,466 \\
\hline $\mathrm{SE}$ & 0 & 0 & 0 & 0 & 246 & 213 & 1,710 & 933 & 1,453 & 3,261 & 2,909 & 4,130 \\
\hline SSE & 0 & 0 & 0 & 35 & 282 & 0 & 5,954 & 1,780 & 3,546 & 2,991 & $3,24.7$ & 3,380 \\
\hline $\mathrm{S}$ & 0 & 0 & 0 & 0 & 250 & 570 & 12,327 & 1,095 & 2,803 & 9,367 & 2,829 & 2,744 \\
\hline SSW & 0 & 0 & 0 & 0 & 0 & 0 & 0 & 318 & 1,518 & 2,978 & 5,556 & 4,590 \\
\hline SW & 0 & 0 & 0 & 0 & 0 & 0 & $710^{\circ}$ & 990 & 1,620 & 3,953 & 4,320 & 4,846 \\
\hline WSW & 0 & 1,112 & 0 & 0 & 0 & 0 & 0 & 470 & 732 & 3,309 & 2,833 & 13,724 \\
\hline W & 0 & 0 & 0 & 0 & 0 & 0 & 1,313 & 669 & 1,975 & 5,684 & 7,106 & 10,573 \\
\hline WWW & 0 & 0 & 0 & 0 & 0 & 0 & 1,568 & 4,341 & 5,456 & 42,402 & 24,875 & 7,668 \\
\hline $\mathrm{NW}$ & 0 & 0 & 0 & 0 & 0 & 7 & 7,970 & 11,817 & 8,353 & 13,856 & 4,110 & 7,239 \\
\hline $\mathrm{NNW}$ & 0 & 0 & 0 & 0 & 421 & 310 & 15,334 & 22,775 & 4,024 & 8,447 & 5,564 & 9,189 \\
\hline $\begin{array}{l}\text { Total (by } \\
\text { distance) }\end{array}$ & 0 & $\begin{array}{l}1,112 \\
\pm 1,926^{a}\end{array}$ & 0 & $\begin{array}{r}186 \\
\pm 237\end{array}$ & $\begin{array}{r}1,642 \\
\pm 927\end{array}$ & $\begin{array}{r}1,385 \\
\pm 1,555\end{array}$ & $\begin{array}{r}63,759 \\
\pm 54,948\end{array}$ & $\begin{array}{r}56,720 \\
\pm 79,376\end{array}$ & $\begin{array}{r}44,434 \\
\pm 17,548\end{array}$ & $\begin{array}{l}136,409 \\
\pm 93,262\end{array}$ & $\begin{array}{l}123,389 \\
\pm 30,247\end{array}$ & $\begin{array}{l}123,954 \\
\pm 29,498\end{array}$ \\
\hline Cumulative & 0 & 1,112 & 1,112 & 1,298 & 2,940 & 4,325 & 68,084 & 124,804 & 169,238 & 305,647 & 429,036 & 552,990 \\
\hline $\begin{array}{l}\text { Density } \\
\left(\text { ind. } / \mathrm{mile}^{2}\right)\end{array}$ & 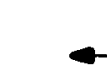 & - & & & & & 289 & $\square$ & & & $-51-$ & \\
\hline
\end{tabular}

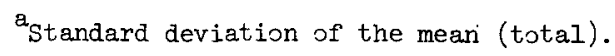


Table 7.'+. Maximum dose $e^{a}$ to ind:viduals ${ }^{b, c}$ from airborne effluents from the model 1500-metric ton/year recycle uranium -- $\mathrm{UF}_{6}$ plant

\begin{tabular}{|c|c|c|c|c|c|c|c|c|c|c|c|}
\hline \multirow{2}{*}{$\begin{array}{l}\text { Radwaste } \\
\text { treatment } \\
\text { case }\end{array}$} & \multirow{2}{*}{$\begin{array}{c}\text { Maximum } \\
\text { total-body } \\
\text { dose } \\
\text { (millirem) } \\
\end{array}$} & \multicolumn{10}{|c|}{ Maximum adult organ dose (millirem) } \\
\hline & & GI tract & Bone & Thyroid & Lungs & Muscle & Kidney & Liver & Spleen & Testes & Ovaries \\
\hline \multicolumn{12}{|c|}{ Midwestern site } \\
\hline $\begin{array}{l}1 \\
2 \\
3 \\
4 \\
5\end{array}$ & $\begin{array}{l}6.1 \mathrm{E}-2 \\
2.5 \mathrm{E}-2 \\
1.8 \mathrm{E}-2 \\
1.2 \mathrm{E}-2 \\
9.6 \mathrm{E}-5\end{array}$ & $\begin{array}{l}9.1 \mathrm{E}-2 \\
3.7 \mathrm{E}-2 \\
2.6 \mathrm{E}-2 \\
1.8 \mathrm{E}-2 \\
1.4 \mathrm{E}-4\end{array}$ & $\begin{array}{l}5.4 \mathrm{E}-1 \\
2.2 \mathrm{E}-1 \\
1.6 \mathrm{E}-1 \\
1.1 \mathrm{E}-1 \\
8.6 \mathrm{E}-4\end{array}$ & $\begin{array}{l}6.1 \mathrm{E}-2 \\
2.5 \mathrm{E}-2 \\
1.8 \mathrm{E}-2 \\
1.2 \mathrm{E}-2 \\
9.7 \mathrm{E}-5\end{array}$ & $\begin{array}{l}2.8 E-1 \\
1.2 E-1 \\
8.2 E-2 \\
5.7 E-2 \\
4.5 E-4\end{array}$ & $\begin{array}{l}5.8 \mathrm{E}-2 \\
2.4 \mathrm{E}-2 \\
1.7 \mathrm{E}-2 \\
1.2 \mathrm{E}-2 \\
9.2 \mathrm{E}-5\end{array}$ & $\begin{array}{l}1.3 E-1 \\
5.4 E-2 \\
3.8 E-2 \\
2.6 E-2 \\
2.1 E-4\end{array}$ & $\begin{array}{l}6.3 \mathrm{E}-2 \\
2.6 \mathrm{E}-2 \\
1.8 \mathrm{E}-2 \\
1.3 \mathrm{E}-2 \\
1.0 \mathrm{E}-4\end{array}$ & $\begin{array}{l}4.9 \mathrm{E}-2 \\
2.0 \mathrm{E}-2 \\
1.4 \mathrm{E}-2 \\
9.8 \mathrm{E}-3 \\
7.7 \mathrm{E}-5\end{array}$ & $\begin{array}{l}5.6 \mathrm{E}-2 \\
2.3 \mathrm{E}-2 \\
1.6 \mathrm{E}-2 . \\
1.1 \mathrm{E}-2 \\
8.8 \mathrm{E}-5\end{array}$ & $\begin{array}{l}4.8 \mathrm{E}-2 \\
2.0 \mathrm{E}-2 \\
1.4 \mathrm{E}-2 \\
9.7 \mathrm{E}-3 \\
7.6 \mathrm{E}-5\end{array}$ \\
\hline \multicolumn{12}{|c|}{ Coastal site } \\
\hline $\begin{array}{l}1 \\
2 \\
3 \\
4 \\
5\end{array}$ & $\begin{array}{l}5.5 \mathrm{E}-2 \\
2.2 \mathrm{E}-2 \\
1.5 \mathrm{E}-2 \\
1.0 \mathrm{E}-2 \\
8.4 \mathrm{E}-5\end{array}$ & $\begin{array}{l}8.4 \mathrm{E}-2 \\
3.3 \mathrm{E}-2 \\
2.3 \mathrm{E}-2 \\
1.6 \mathrm{E}-2 \\
1.3 \mathrm{E}-4\end{array}$ & $\begin{array}{l}4.7 \mathrm{E}-1 \\
1.9 \mathrm{E}-1 \\
1.3 \mathrm{E}-1 \\
8.8 \mathrm{E}-2 \\
7.3 \mathrm{E}-4\end{array}$ & $\begin{array}{l}5.5 \mathrm{E}-2 \\
2.2 \mathrm{E}-2 \\
1.5 \mathrm{E}-2 \\
1.0 \mathrm{E}-2 \\
8.5 \mathrm{E}-5\end{array}$ & $\begin{array}{l}2.4 \mathrm{E}-1 \\
9.4 \mathrm{E}-2 \\
6.5 \mathrm{E}-2 \\
4.4 \mathrm{E}-2 \\
3.7 \mathrm{E}-4\end{array}$ & $\begin{array}{l}5.3 \mathrm{E}-2 \\
2.1 \mathrm{E}-2 \\
1.5 \mathrm{E}-2 \\
9.8 \mathrm{E}-3 \\
8.1 \mathrm{E}-5\end{array}$ & $\begin{array}{l}1.2 \mathrm{E}-1 \\
4.6 \mathrm{E}-2 \\
3.2 \mathrm{E}-2 \\
2.2 \mathrm{E}-2 \\
1.8 \mathrm{E}-4\end{array}$ & $\begin{array}{l}5.6 \mathrm{E}-2 \\
2.2 \mathrm{E}-2 \\
1.5 \mathrm{E}-2 \\
1.0 \mathrm{E}-2 \\
8.6 \mathrm{E}-5\end{array}$ & $\begin{array}{l}4.4 \mathrm{E}-2 \\
1.7 \mathrm{E}-2 \\
1.2 \mathrm{E}-2 \\
8.2 \mathrm{E}-3 \\
6.7 \mathrm{E}-5\end{array}$ & $\begin{array}{l}\text { 5. OE-2 } \\
2.0 \mathrm{E}-2 \\
1.4 \mathrm{E}-2 \\
9.4 \mathrm{E}-3 \\
7.7 \mathrm{E}-5\end{array}$ & $\begin{array}{l}4.3 \mathrm{E}-2 \\
1.7 \mathrm{E}-2 \\
1.2 \mathrm{E}-2 \\
8.0 \mathrm{E}-3 \\
6.6 \mathrm{E}-5\end{array}$ \\
\hline
\end{tabular}

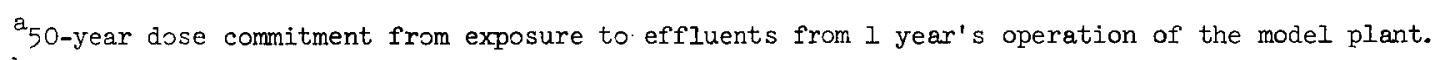

baximum dose to individuals at 1.5 miles and downind of the prevailing wind direction; maximum doses at 0.5 mile and at 1.0 mile are 2.3 and 1.5 times higher.

$\mathrm{c}_{\mathrm{All}}$ food is produced and consumed at the location of the dose calculation. Daily intakes are 1 liter of milk, $0.25 \mathrm{~kg}$ of vegetables, and $0.3 \mathrm{~kg}$ of beef. 
Table 7.5. Summary of annual doses ${ }^{a}$ to the population ${ }^{b}$ from airborne effluents from the model 1500-metric ton/year recycle uranium -- $\mathrm{UF}_{6}$ plant

\begin{tabular}{|c|c|c|c|c|c|c|c|c|c|c|c|}
\hline \multirow{2}{*}{$\begin{array}{l}\text { Radwaste } \\
\text { treatment } \\
\text { case } \\
\end{array}$} & \multirow{2}{*}{$\begin{array}{l}\text { Total-body } \\
\text { dose } \\
\text { (person-rem) }\end{array}$} & \multicolumn{10}{|c|}{ Population organ doses (person-organ-rem) } \\
\hline & & GI tract & Bone & Thyroid & Iungs & Muscle & Kidney & Liver & Spleen & Testes & Ovaries \\
\hline \multicolumn{12}{|c|}{ Midwestern site } \\
\hline $\begin{array}{l}1 \\
2 \\
3 \\
4 \\
5\end{array}$ & $\begin{array}{l}1.39 \mathrm{E} 00 \\
5.51 \mathrm{E}-1 \\
3.81 \mathrm{E}-1 \\
2.65 \mathrm{E}-1 \\
2.09 \mathrm{E}-3\end{array}$ & $\begin{array}{l}2.03 \mathrm{E} 00 \\
8.04 \mathrm{E}-1 \\
5.56 \mathrm{E}-1 \\
3.86 \mathrm{E}-1 \\
3.04 \mathrm{E}-3\end{array}$ & $\begin{array}{l}1.14 \mathrm{E}+1 \\
4.52 \mathrm{EOO} \\
3.13 \mathrm{E} 00 \\
2.17 \mathrm{E} 00 \\
1.71 \mathrm{E}-2\end{array}$ & $\begin{array}{l}1.40 \mathrm{E} 00 \\
5.54 \mathrm{E}-1 \\
3.84 \mathrm{E}-1 \\
2.66 \mathrm{E}-1 \\
2.10 \mathrm{E}-3\end{array}$ & $\begin{array}{l}5.72 \mathrm{E} 00 \\
2.27 \mathrm{EOOO} \\
1.57 \mathrm{E} 00 \\
1.09 \mathrm{E} 00 \\
8.59 \mathrm{E}-3\end{array}$ & $\begin{array}{l}1.33 \mathrm{E} 00 \\
5.27 \mathrm{E}-1 \\
3.65 \mathrm{E}-1 \\
2.53 \mathrm{E}-1 \\
2.00 \mathrm{E}-3\end{array}$ & $\begin{array}{l}2.83 \mathrm{E} 00 \\
1.12 \mathrm{E} 00 \\
7.76 \mathrm{E}-1 \\
5.39 \mathrm{E}-1 \\
4.25 \mathrm{E}-3\end{array}$ & $\begin{array}{l}1.39 \mathrm{E} 00 \\
5.50 \mathrm{E}-1 \\
3.81 \mathrm{E}-1 \\
2.64 \mathrm{E}-1 \\
2.08 \mathrm{E}-3\end{array}$ & $\begin{array}{l}1.10 \mathrm{E} 00 \\
4.35 \mathrm{E}-1 \\
3.01 \mathrm{E}-1 \\
2.09 \mathrm{E}-1 \\
1.65 \mathrm{E}-3\end{array}$ & $\begin{array}{l}1.27 \mathrm{E} 00 \\
5.02 \mathrm{E}-1 \\
3.48 \mathrm{E}-1 \\
2.41 \mathrm{E}-1 \\
1.90 \mathrm{E}-3\end{array}$ & $\begin{array}{l}1.08 \mathrm{E} 00 \\
4.28 \mathrm{E}-1 \\
2.96 \mathrm{E}-1 \\
2.06 \mathrm{E}-1 \\
1.62 \mathrm{E}-3\end{array}$ \\
\hline \multicolumn{12}{|c|}{ Coastal site } \\
\hline $\begin{array}{l}1 \\
2 \\
3 \\
4 \\
5\end{array}$ & $\begin{array}{l}7.53 \mathrm{E}-1 \\
2.97 \mathrm{E}-1 \\
2.04 \mathrm{E}-1 \\
1.40 \mathrm{E}-1 \\
1.13 \mathrm{E}-3\end{array}$ & $\begin{array}{l}1.08 \mathrm{E} 00 \\
4.26 \mathrm{E}-1 \\
2.94 \mathrm{E}-1 \\
2.02 \mathrm{E}-1 \\
1.62 \mathrm{E}-3\end{array}$ & $\begin{array}{l}6.38 \mathrm{EOOO} \\
2.51 \mathrm{EOO} \\
1.72 \mathrm{E} 00 \\
1.18 \mathrm{E} 00 \\
9.51 \mathrm{E}-3\end{array}$ & $\begin{array}{l}7.57 \mathrm{E}-1 \\
2.98 \mathrm{E}-1 \\
2.06 \mathrm{E}-1 \\
1.41 \mathrm{E}-1 \\
1.13 \mathrm{E}-3\end{array}$ & $\begin{array}{l}3.34 \mathrm{E} 00 \\
1.31 \mathrm{E} 00 \\
8.95 \mathrm{E}-1 \\
6.07 \mathrm{E}-1 \\
4.96 \mathrm{E}-3\end{array}$ & $\begin{array}{l}7.20 \mathrm{E}-1 \\
2.84 \mathrm{E}-1 \\
1.96 \mathrm{E}-1 \\
1.34 \mathrm{E}-1 \\
1.08 \mathrm{E}-3\end{array}$ & $\begin{array}{l}1.56 \mathrm{E} 00 \\
6.12 \mathrm{E}-1 \\
4.22 \mathrm{E}-1 \\
2.88 \mathrm{E}-1 \\
2.32 \mathrm{E}-3\end{array}$ & $\begin{array}{l}7.67 \mathrm{E}-1 \\
3.01 \mathrm{E}-1 \\
2.07 \mathrm{E}-1 \\
1.42 \mathrm{E}-1 \\
1.14 \mathrm{E}-3\end{array}$ & $\begin{array}{l}5.97 \mathrm{E}-1 \\
2.35 \mathrm{E}-1 \\
1.62 \mathrm{E}-1 \\
1.11 \mathrm{E}-1 \\
8.92 \mathrm{E}-4\end{array}$ & $\begin{array}{l}6.87 \mathrm{E}-1 \\
2.71 \mathrm{E}-1 \\
1.86 \mathrm{E}-1 \\
1.28 \mathrm{E}-1 \\
1.03 \mathrm{E}-3\end{array}$ & $\begin{array}{l}5.87 \mathrm{E}-1 \\
2.31 \mathrm{E}-1 \\
1.59 \mathrm{E}-1 \\
1.09 \mathrm{E}-1 \\
8.77 \mathrm{E}-4\end{array}$ \\
\hline
\end{tabular}

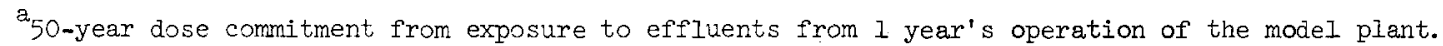

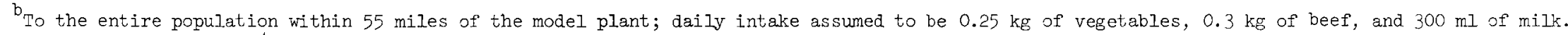
It is assumed that $100 \%$ of the food consumed is produced or grown at the location of dose calculation. 
Table 7.6. Contribution of exposure modes to total-body dose from the airborne effluents of a model 1500-metric ton/year recycle uranium -- UF 6 plant $^{a}$

\begin{tabular}{lcc}
\hline Exposure mode & $\begin{array}{c}\text { Annual dose } \\
\text { (millirem) }\end{array}$ & $\begin{array}{c}\text { Percent of } \\
\text { total dose }\end{array}$ \\
\hline Immersion in air & $4.9 \mathrm{E}-7$ & $<0.1$ \\
Contaminated ground $^{\text {Inhalation }}{ }^{\mathrm{b}}$ & $3.5 \mathrm{E}-2$ & 56.8 \\
Ingestion $^{\mathrm{c}}$ & $8.9 \mathrm{E}-3$ & 14.7 \\
\hline
\end{tabular}

a Radwaste treatment Case $I$ at 1.5 miles from the plant in the prevailing wind direction; midwestern site.

baily intake assumed to be $20 \mathrm{~m}^{3}$ of air.

${ }^{c}$ Daily intake assumed to be $0.25 \mathrm{~kg}$ of vegetables, $0.3 \mathrm{~kg}$ of beef, and I liter of milk. It is also assumed that $100 \%$ of the food consumed is produced or grown at the reference location. 
Table 7.7. Contribution of major radionuclides ${ }^{\mathrm{a}}$ to total-body and organ doses ${ }^{b}$ of individuals at 1.5 miles from the model

1500-metric ton/year recycle uranium -- UF 6 plant

\begin{tabular}{|c|c|c|c|c|c|}
\hline \multirow[b]{2}{*}{ Radionuclide } & \multicolumn{5}{|c|}{ Percent of total-body and organ dose } \\
\hline & Total body & GI tract & Bone & Iung & Kidney \\
\hline $\mathrm{Sr}-90$ & 0.05 & 0.01 & $0.3 I$ & 0.01 & 0.02 \\
\hline Zr-95 & 0.21 & 0.24 & 0.03 & 0.05 & 0.09 \\
\hline $\mathrm{Nb}-95$ & 0.11 & 0.44 & 0.01 & 0.03 & 0.05 \\
\hline Tc-99 & 0.20 & 25.8 & 0.06 & 0.07 & 4.26 \\
\hline $\mathrm{Ru}-103$ & 0.01 & 0.17 & 0.00 & 0.00 & 0.00 \\
\hline $\mathrm{Ru}-106$ & 0.35 & 19.0 & 0.08 & 0.11 & 0.45 \\
\hline $\mathrm{Cs}-134$ & 0.49 & 0.22 & 0.05 & 0.01 & 0.18 \\
\hline $\mathrm{Cs}-137$ & 0.58 & 0.30 & 0.08 & 0.11 & 0.24 \\
\hline $\mathrm{Ce}-144$ & 0.01 & 0.25 & 0.01 & 0.01 & 0.01 \\
\hline $\mathrm{Eu}-154$ & 0.05 & 0.03 & 0.01 & 0.01 & 0.02 \\
\hline Th-234 & 0.01 & 0.98 & 0.01 & 0.01 & 0.03 \\
\hline U-232 & 25.3 & 13.0 & 5.81 & 8.19 & 10.0 \\
\hline$U-234$ & 27.4 & 15.2 & 40.4 & 51.5 & 39.9 \\
\hline$U-235$ & 9.81 & 3.65 & 2.28 & 2.56 & 3.76 \\
\hline $\mathrm{U}-236$ & 7.83 & 4.45 & 12.4 & 18.5 & 12.1 \\
\hline U-237 & 0.19 & 0.07 & 0.04 & 0.04 & 0.07 \\
\hline U-238 & 21.2 & 15.5 & 15.1 & 17.6 & 16.3 \\
\hline Np-237 & 1.82 & 0.40 & 2.74 & 0.34 & 3.56 \\
\hline$P u-238$ & 2.61 & 0.06 & 11.6 & 0.74 & 5.12 \\
\hline$P u-239$ & 0.22 & 0.00 & 1.05 & 0.05 & 0.45 \\
\hline$P u-240$ & 0.33 & 0.01 & 1.53 & 0.08 & 0.65 \\
\hline$P u-241$ & 1.14 & 0.08 & 6.24 & 0.02 & 2.53 \\
\hline $\mathrm{Cm}-244$ & 0.05 & 0.07 & 0.10 & 0.01 & 0.12 \\
\hline
\end{tabular}

a Radionuclides contributing $<0.01 \%$ are not included.

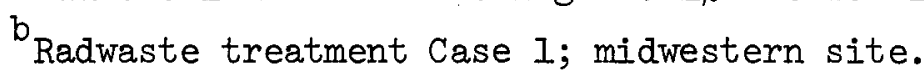


Table 7.8. Contribution of major radionuclides ${ }^{a}$ to total-body and organ doses ${ }^{b}$ of the population out to 55 miles from the model 1500-metric ton/year recycle uranium -- $\mathrm{UF}_{6}$ plant, midwestern site

\begin{tabular}{|c|c|c|c|c|c|}
\hline \multirow[b]{2}{*}{ Radionuclide } & \multicolumn{5}{|c|}{ Percent of total-body and organ dose (population) } \\
\hline & Total body & GI tract & Bone & Lung & Kidney \\
\hline Sr-90 & 0.04 & 0.01 & 0.27 & 0.01 & 0.02 \\
\hline $\mathrm{Zr}-95$ & 0.23 & 0.26 & 0.03 & 0.05 & 0.10 \\
\hline $\mathrm{Nb}-95$ & 0.12 & 0.43 & 0.02 & 0.03 & 0.06 \\
\hline Tc-99 & 0.16 & 22.2 & 0.05 & 0.06 & 3.76 \\
\hline$R u-103$ & 0.01 & 0.19 & 0.00 & 0.00 & 0.01 \\
\hline $\mathrm{Ru}-106$ & 0.37 & 20.7 & 0.09 & 0.12 & 0.50 \\
\hline $\mathrm{Cs}-134$ & 0.40 & 0.19 & 0.05 & 0.08 & 0.17 \\
\hline $\mathrm{Cs}-137$ & 0.58 & 0.30 & 0.09 & 0.13 & 0.25 \\
\hline $\mathrm{Ce}-144$ & 0.01 & 0.27 & 0.01 & 0.01 & 0.01 \\
\hline$E u-154$ & 0.05 & 0.03 & 0.01 & 0.01 & 0.02 \\
\hline$T h-234$ & 0.00 & 1.05 & 0.01 & 0.01 & 0.03 \\
\hline $\mathrm{U}-232$ & 26.5 & 14.1 & 6.26 & 8.92 & 11.1 \\
\hline$U-234$ & 26.2 & 15.2 & 40.9 & 48.2 & 39.4 \\
\hline $\mathrm{U}-235$ & 10.4 & $3 \cdot 96$ & 2.53 & 2.85 & 4.14 \\
\hline $\mathrm{U}-236$ & 7.78 & 4.46 & 13.2 & 21.2 & 12.7 \\
\hline U-237 & 0.20 & 0.07 & 0.04 & 0.05 & 0.08 \\
\hline $\mathrm{U}-238$ & 21.6 & 15.90 & 15.7 & 17.1 & 16.8 \\
\hline $\mathrm{Np}-237$ & 1.70 & 0.43 & 2.49 & 0.38 & 3.19 \\
\hline$P u-238$ & 2.15 & 0.06 & 10.3 & 0.68 & 4.45 \\
\hline Pu-239 & 0.19 & 0.00 & 0.93 & 0.05 & 0.39 \\
\hline$P u-240$ & 0.27 & 0.01 & 1.36 & 0.07 & 0.57 \\
\hline $\mathrm{Pu}-241$ & 0.94 & 0.08 & 5.57 & 0.02 & 2.21 \\
\hline $\mathrm{Cm}-244$ & 0.06 & 0.07 & 0.11 & 0.01 & 0.13 \\
\hline
\end{tabular}

Radionuclides contributing $<0.01 \%$ to dose are not included.

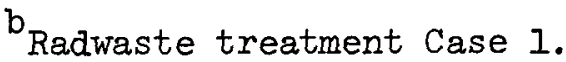


Table 7.9. Contribution of major radionuclides ${ }^{2}$ to total-body and organ doses $\mathrm{b}$ of the population out to 55 miles from the model

1500-metric ton/year recycle uranium -- $\mathrm{UF}_{6}$ plant, southeastern coastal site

\begin{tabular}{|c|c|c|c|c|c|}
\hline \multirow[b]{2}{*}{ Radionuclide } & \multicolumn{5}{|c|}{ Percent of total-body and organ dose (population) } \\
\hline & Total body & GI tract & Bone & Lung & Kidney \\
\hline $\mathrm{S} r-90$ & 0.04 & 0.01 & 0.25 & 0.01 & 0.02 \\
\hline $\mathrm{Zr}-95$ & 0.22 & 0.26 & 0.03 & 0.05 & 0.10 \\
\hline $\mathrm{Nb}-95$ & 0.12 & 0.43 & 0.02 & 0.03 & 0.05 \\
\hline Tc-99 & 0.16 & $22: 1$ & 0.05 & 0.06 & 3.63 \\
\hline$R u-103$ & 0.01 & 0.19 & 0.00 & 0.00 & 0.01 \\
\hline Ru-106 & 0.36 & 20.7 & 0.09 & 0.12 & 0.48 \\
\hline$C s-134$ & 0.40 & 0.19 & 0.05 & 0.07 & 0.16 \\
\hline CS -137 & 0.57 & 0.29 & 0.08 & 0.12 & 0.24 \\
\hline $\mathrm{Ce}-\mathrm{I} 44$ & 0.01 & 0.27 & 0.01 & 0.01 & 0.01 \\
\hline $\mathrm{Eu}-154$ & 0.05 & 0.03 & 0.01 & 0.01 & 0.02 \\
\hline$T h-234$ & 0.01 & 1.06 & 0.01 & 0.01 & 0.03 \\
\hline $\mathrm{U}-232$ & 26.1 & 14.1 & 6.04 & 8.48 & 10.8 \\
\hline $\mathrm{U}-234$ & 26.4 & 15.2 & 40.1 & 49.6 & 39.2 \\
\hline U-235 & 10.2 & 3.95 & 2.42 & 2.68 & 4.02 \\
\hline U-236 & 7.90 & 4.57 & 13.0 & 20.2 & 12.6 \\
\hline $\mathrm{U}-237$ & 0.20 & 0.07 & 0.04 & 0.04 & 0.08 \\
\hline U-238 & 21.4 & 15.9 & 15.3 & 17.3 & 16.5 \\
\hline Np-237 & 1.78 & 0.43 & 2.68 & 0.36 & 3.47 \\
\hline Pu-238 & 2.42 & 0.06 & 11.3 & 0.71 & 4.92 \\
\hline$P u-239$ & 0.21 & 0.00 & 1.01 & 0.05 & 0.43 \\
\hline$P u-240$ & 0.31 & 0.01 & 1.48 & 0.08 & 0.63 \\
\hline $\mathrm{Pu}-24 \mathrm{I}$ & 1.05 & 0.08 & 6.05 & 0.02 & 2.44 \\
\hline $\mathrm{Cm}-244$ & 0.05 & 0.07 & 0.11 & 0.01 & 0.12 \\
\hline
\end{tabular}

Radionuclides contributing $<0.01 \%$ to dose are not included.

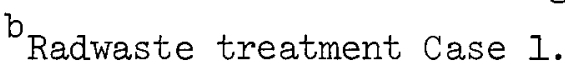




\section{LIST OF FIGURES}

Fig. 3.1 Artist's conception of the UF facility constructed by

Allied-General Nuclear Services near Barnwell, South Carolina. ............ 96

Fig. 3.2 Simplified flow diagram for the uranium hexafluoride process $\ldots \ldots \ldots \ldots \ldots \ldots 7$

Fig. 4.1 Process and waste treatment system for the production of uranium dioxide from uranyl nitrate $\ldots \ldots \ldots \ldots \ldots \ldots \ldots \ldots \ldots$

Fig. 4.2 Process and waste treatment system for the production of uranium hexafluoride from uranium dioxide ................... 99

Fig. 4.3 Process and waste treatment system for the production of fluorine $\ldots \ldots \ldots \ldots 100$

Fig. 4.4 Process and waste treatment system for the scrap recovery

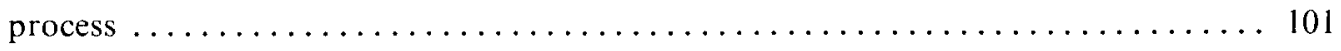

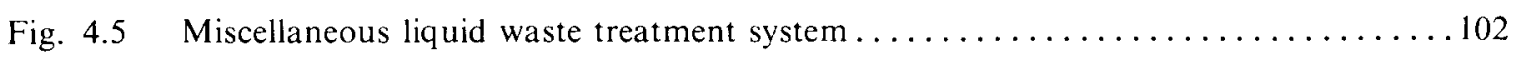

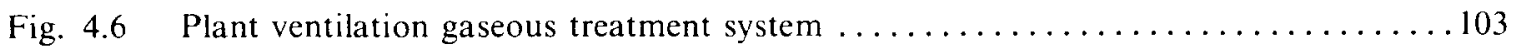

Fig. $7.1 \quad$ Pathways for external and internal exposure of $\operatorname{man} \ldots \ldots \ldots \ldots \ldots \ldots \ldots \ldots$

Fig. 8.1 Annual cost for reduction of maximum annual individual organ and total-body doses from airborne effluents at 1.5 miles from the model recycle uranium - UF 6 plant (Doses are for the

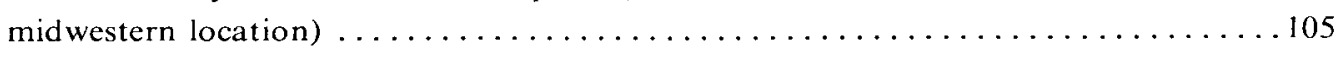

Fig. 8.2 Annual cost for reduction of annual population individual organ and total-body doses out to a radius of 55 miles from the model recycle uranium - UF 6 plant (Doses are for the midwestern

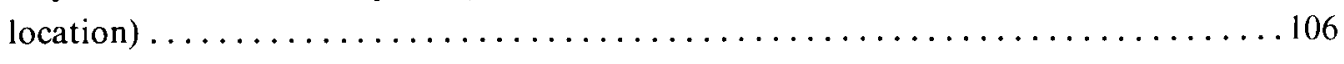


Table 7.10. Percent of contribution of radionuclides ${ }^{a}$ to total-body dose ${ }^{b}$ by pathway from the airborne effluents of a model 1500-metric ton/year recycle uranium -- UF6 plant

\begin{tabular}{|c|c|c|c|c|}
\hline \multirow[b]{2}{*}{ Radionuclide } & \multicolumn{4}{|c|}{ Percent of total-body dose by pathway } \\
\hline & $\begin{array}{c}\text { Contaminated } \\
\text { ground }\end{array}$ & Ingestion & Inhalation & $\begin{array}{c}\text { Submersion } \\
\text { in air }\end{array}$ \\
\hline Sr-90 & $<0.1$ & 0.1 & $<0.1$ & $<0.1$ \\
\hline Zr-95 & 0.2 & $<0.1$ & $<0.1$ & $<0.1$ \\
\hline $\mathrm{Nb}-95$ & 0.1 & $<0.1$ & $<0.1$ & $<0.1$ \\
\hline Tc-99 & $<0.1$ & 0.2 & $<0.1$ & $<0.1$ \\
\hline $\mathrm{Ru}-106$ & 0.3 & $<0.1$ & $<0.1$ & $<0.1$ \\
\hline $\mathrm{Cs}-134$ & 0.3 & 0.3 & $<0.1$ & $<0.1$ \\
\hline Cs -137 & 0.5 & 0.1 & $<0.1$ & $<0.1$ \\
\hline $\mathrm{Ce}-144$ & $<0.1$ & $<0 . I$ & $<0.1$ & $<0.1$ \\
\hline Eu-154 & 0.1 & $<0.1$ & $<0.1$ & $<0.1$ \\
\hline U-232 & 23.4 & 1.4 & 0.5 & $<0.1$ \\
\hline$U-234$ & 5.4 & 17.0 & 5.4 & $<0.1$ \\
\hline U-235 & 9.5 & 0.3 & 0.1 & $<0.1$ \\
\hline$U-236$ & 1.1 & 4.8 & 1.9 & $<0.1$ \\
\hline U-237 & 0.2 & $<0.1$ & $<0.1$ & $<0.1$ \\
\hline $\mathrm{U}-238$ & 15.0 & 4.9 & 1.6 & $<0.1$ \\
\hline $\mathrm{Np}-237$ & 0.9 & $<0.1$ & 0.9 & $<0.1$ \\
\hline$P u-238$ & $<0.1$ & $<0.1$ & 2.6 & $<0.1$ \\
\hline$P u-239$ & $<0.1$ & $<0.1$ & 0.2 & $<0.1$ \\
\hline$P u-240$ & $<0.1$ & $<0.1$ & 0.3 & $<0.1$ \\
\hline$P u-241$ & $<0.1$ & $<0.1$ & 1.1 & $<0.1$ \\
\hline
\end{tabular}

Radionuclides contributing $<0.1 \%$ are not included.

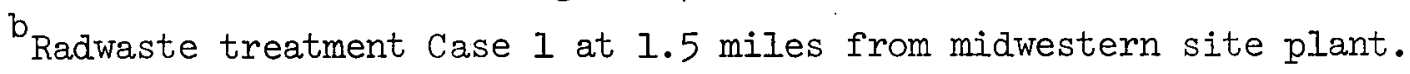


Table 7.11. Percent contribution to organ dose ${ }^{a}$ of inhaled and ingested radionuclides ${ }^{b}$ from airborne effluents of a model 1500-metric ton/year recycle uranium -- UF 6 plant

\begin{tabular}{|c|c|c|c|c|c|c|c|c|}
\hline \multirow[b]{2}{*}{ Radionuclide } & \multicolumn{2}{|c|}{ GI tract } & \multicolumn{2}{|c|}{ Bone } & \multicolumn{2}{|c|}{ Lung } & \multicolumn{2}{|c|}{ Kidney } \\
\hline & Inhaled $^{c}$ & Ingested $^{\mathrm{d}}$ & Inhaled $^{c}$ & Ingested $^{\mathrm{d}}$ & Inhaled ${ }^{c}$ & Ingested $^{\bar{\alpha}}$ & Inhaled $^{c}$ & Ingested $^{\mathrm{d}}$ \\
\hline Sr-90 & $<0.1$ & $<0.1$ & $<0.1$ & 0.3 & $<0.1$ & $<0.1$ & $<0.1$ & $<0.1$ \\
\hline Zr-95 & $<0.1$ & 0.1 & $<0.1$ & $<0.1$ & $<0.1$ & $<0.1$ & $<0.1$ & $<0.1$ \\
\hline $\mathrm{Nb}-95$ & $<0.1$ & 0.4 & $<0.1$ & $<0.1$ & $<0.1$ & $<0.1$ & $<0.1$ & $<0.1$ \\
\hline Tc-99 & $<0.1$ & 25.8 & $<0.1$ & 0.1 & 0.1 & $<0.1$ & $<0.1$ & 4.3 \\
\hline $\mathrm{Ru}-103$ & $<0.1$ & 0.2 & $<0.1$ & $<0.1$ & $<0.1$ & $<0.1$ & $<0.1$ & $<0.1$ \\
\hline Ru-106 & $<0.1$ & 18.9 & $<0.1$ & $<0.1$ & $<0.1$ & $<0.1$ & $<0.1$ & 0.3 \\
\hline $\mathrm{Cs}-134$ & $<0.1$ & 0.1 & $<0.1$ & $<0.1$ & $<0.1$ & $<0.1$ & $<0.1$ & 0.1 \\
\hline $\mathrm{Cs}-137$ & $<0.1$ & 0.1 & $<0.1$ & 0.1 & $<0.1$ & $<0.1$ & $<0.1$ & $<0.1$ \\
\hline $\mathrm{Ce}-144$ & $<0.1$ & 0.2 & $<0.1$ & $<0.1$ & $<0.1$ & $<0.1$ & $<0.1$ & $<0.1$ \\
\hline Th-234 & $<0.1$ & 1.0 & $<0.1$ & $<0.1$ & $<0.1$ & $<0.1$ & $<0.1$ & $<0.1$ \\
\hline U-232 & $<0.1$ & 0.2 & 0.7 & 2.2 & 3.0 & 0.3 & 0.3 & 1.0 \\
\hline U-234 & 0.1 & 16.1 & 9.7 & 30.1 & 47.4 & 3.6 & 9.5 & 29.6 \\
\hline $\mathrm{U}-235$ & $<0.1$ & 0.2 & 0.2 & 0.5 & 0.7 & 0.1 & 0.2 & 0.5 \\
\hline U-236 & $<0.1$ & 4.2 & 3.5 & 8.7 & 17.4 & 1.0 & 3.5 & 8.6 \\
\hline $\mathrm{U}-238$ & $<0.1$ & 10.5 & 3.0 & 9.2 & 13.9 & 1.1 & 2.8 & 8.7 \\
\hline Np-237 & $<0.1$ & $<0.1$ & 2.5 & 0.1 & 0.1 & $<0.1$ & 3.2 & 0.1 \\
\hline$P u-238$ & $<0.1$ & 0.1 & 11.5 & 0.1 & 0.7 & $<0.1$ & 5.1 & $<0.1$ \\
\hline$P u-239$ & $<0.1$ & $<0.1$ & 1.0 & $<0.1$ & 0.1 & $<0.1$ & 0.4 & $<0.1$ \\
\hline$P u-240$ & $<0.1$ & $<0.1$ & 1.5 & $<0.1$ & 0.1 & $<0.1$ & 0.7 & $<0.1$ \\
\hline $\mathrm{Pu}-24 \mathrm{I}$ & $<0.1$ & 0.1 & 6.1 & 0.1 & $<0.1$ & $<0.1$ & 2.5 & $<0.1$ \\
\hline $\mathrm{Cm}-244$ & $<0.1$ & 0.1 & $<0.1$ & 0.1 & $<0.1$ & $<0.1$ & $<0.1$ & 0.1 \\
\hline
\end{tabular}

Radwaste treatment Case 1; 1.5 miles from effluents of midwestern site plant.

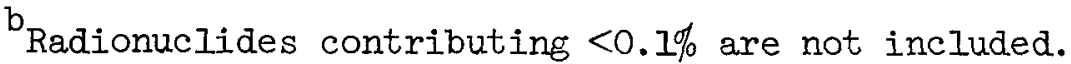

${ }^{c}$ Daily intake of $20 \mathrm{~m}^{3}$ of air is assumed.

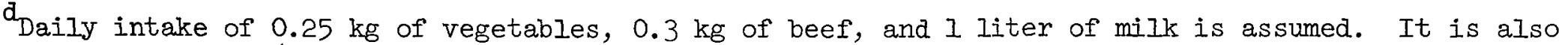
assumed that $100 \%$ of the food consumed is produced or grown at the reference location. 
Table 7.12. Curies and concentrations on the ground of long-lived radionuclides released during the 30-year life of the model 1500-metric ton/year recycle uranium -- $\mathrm{UF}_{6}$ plant

\begin{tabular}{|c|c|c|}
\hline Radionuclide & $\begin{array}{l}\text { Release during } \\
\text { 30-year life of plant } \\
\text { (Ci) }\end{array}$ & $\begin{array}{c}\text { Concentration on } \\
\text { the earth } \\
\left(\mathrm{Ci} / \mathrm{m}^{2}\right) \\
\end{array}$ \\
\hline Tc-99 & 8. $3 E-1$ & $3.4 E-11$ \\
\hline $\mathrm{U}-232$ & $2.1 E-2$ & $8.5 E-13$ \\
\hline$U-234$ & $1.4 \mathrm{E} 00$ & $5.7 \mathrm{E}-11$ \\
\hline U-235 & $2 \cdot 3 E-2$ & $9 \cdot 3 E-13$ \\
\hline$U-236$ & $5 \cdot 3 E-1$ & $2.2 \mathrm{E}-11$ \\
\hline $\mathrm{U}-238$ & 4.7E-1 & $1.9 \mathrm{E}-11$ \\
\hline $\mathrm{Np}-237$ & $2 \cdot 3 \mathrm{E}-3$ & $9 \cdot 3 E-14$ \\
\hline $\mathrm{Pu}-238$ & $6.2 E-3$ & $2.5 \mathrm{E}-13$ \\
\hline$P u-239$ & $4.8 E-4$ & 2.OE-14 \\
\hline$P u-240$ & $7.1 E-4$ & 2. $9 \mathrm{E}-14$ \\
\hline
\end{tabular}

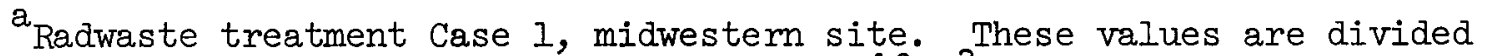
by area within $55-$ mile radius $\left(2.46 \times 10^{10} \mathrm{~m}^{2}\right)$ of plant to give assumed deposition rate.

beposition is assumed to occur uniformly out to a distance of 55 miles. 
Table 7.13. Contribution of radionuclides and exposure modes from contaminated ground to the annual total-body dose ${ }^{a}$ to individuals from the time of cessation of the model 1500-metric ton/year recycle uranium -- UF6 plant operation until significant decay of all radionuclides occurs

\begin{tabular}{lllll}
\hline & \multicolumn{2}{c}{ Total-body dose (millirem) } & per exposure mode \\
\cline { 2 - 4 } Radionuclide & $\begin{array}{c}\text { Contaminated } \\
\text { ground }\end{array}$ & Inhalation & Ingestion & Total \\
\hline Tc-99 & 0 & $1.2 \mathrm{E}-11$ & $1.7 \mathrm{E}-7$ & $1.7 \mathrm{E}-7$ \\
$\mathrm{U}-232$ & $2.5 \mathrm{E}-6$ & $4.5 \mathrm{E}-8$ & $3.4 \mathrm{E}-7$ & $2.9 \mathrm{E}-6$ \\
$\mathrm{U}-234$ & $1.5 \mathrm{E}-4$ & $5.5 \mathrm{E}-7$ & $4.1 \mathrm{E}-6$ & $1.5 \mathrm{E}-4$ \\
$\mathrm{U}-235$ & $3.3 \mathrm{E}-5$ & $8.2 \mathrm{E}-9$ & $6.2 \mathrm{E}-8$ & $3.3 \mathrm{E}-5$ \\
$\mathrm{U}-236$ & $5.3 \mathrm{E}-5$ & $2.0 \mathrm{E}-7$ & $1.5 \mathrm{E}-6$ & $5.5 \mathrm{E}-5$ \\
$\mathrm{U}-238$ & $4.0 \mathrm{E}-7$ & $1.6 \mathrm{E}-7$ & $1.2 \mathrm{E}-6$ & $1.8 \mathrm{E}-6$ \\
$\mathrm{~Np}-237$ & $1.5 \mathrm{E}-6$ & $9.4 \mathrm{E}-8$ & $7.2 \mathrm{E}-9$ & $1.6 \mathrm{E}-6$ \\
Pu-238 & $6.5 \mathrm{E}-7$ & $2.6 \mathrm{E}-7$ & $2.0 \mathrm{E}-9$ & $9.1 \mathrm{E}-7$ \\
Pu-239 & $2.0 \mathrm{E}-8$ & $2.3 \mathrm{E}-8$ & $1.8 \mathrm{E}-10$ & $4.3 \mathrm{E}-8$ \\
Pu-240 & $6.5 \mathrm{E}-8$ & $3.4 \mathrm{E}-8$ & $2.7 \mathrm{E}-10$ & $9.9 \mathrm{E}-8$ \\
Total & $2.4 \mathrm{E}-4$ & $1.4 \mathrm{E}-6$ & $7.4 \mathrm{E}-6$ & $2.5 \mathrm{E}-4$ \\
\hline
\end{tabular}

Dose is the average total-body dose of the individuals out to a distance of 55 miles from the plant. $\mathrm{b}_{\mathrm{A}}$ 30-year lifetime for the plant is assumed. 
Table 7.14. Annual dose ${ }^{2}$ to organs of individuals (from long-lived radionuclides deposited on the ground during the operating $l i f e^{b}$ of the model 1500-metric ton/year recycle uranium -- UF 6 plant) from cessation of plant operation until significant decay of all radionuclides occurs

\begin{tabular}{|c|c|c|c|c|c|c|}
\hline \multirow[b]{3}{*}{ Radionuclide } & \multicolumn{6}{|c|}{ Organ dose (millirem) per exposure mode } \\
\hline & \multicolumn{2}{|c|}{ GI tract } & \multicolumn{2}{|c|}{ Bone } & \multicolumn{2}{|c|}{ Kidney } \\
\hline & Inhalation & Ingestion & Inhalation & Ingestion & Inhalation & Ingestion \\
\hline $\begin{array}{l}T c-99 \\
U-232 \\
U-234 \\
U-235 \\
U-236 \\
U-238 \\
N p-237 \\
P u-238 \\
\text { Pu-239 } \\
\text { Pu-240 } \\
\text { Total }\end{array}$ & $\begin{array}{l}3.8 \mathrm{E}-12 \\
2.6 \mathrm{E}-10 \\
1.5 \mathrm{E}-8 \\
2.9 \mathrm{E}-10 \\
5.7 \mathrm{E}-9 \\
4.9 \mathrm{E}-9 \\
2.9 \mathrm{E}-11 \\
7.8 \mathrm{E}-11 \\
6.2 \mathrm{E}-12 \\
9.1 \mathrm{E}-12 \\
2.6 \mathrm{E}-8\end{array}$ & $\begin{array}{l}3 \cdot 3 \mathrm{E}-5 \\
7 \cdot 7 \mathrm{E}-8 \\
5 \cdot 2 \mathrm{E}-6 \\
8.4 \mathrm{E}-8 \\
1.9 \mathrm{E}-6 \\
1.3 \mathrm{E}-6 \\
8.4 \mathrm{E}-9 \\
7 \cdot 7 \mathrm{E}-9 \\
6.2 \mathrm{E}-10 \\
9 \cdot 0 \mathrm{E}-10 \\
4.2 \mathrm{E}-5\end{array}$ & $\begin{array}{l}3.1 \mathrm{E}-11 \\
6.5 \mathrm{E}-7 \\
8.8 \mathrm{E}-6 \\
1.5 \mathrm{E}-7 \\
3 \cdot 3 \mathrm{E}-6 \\
2.7 \mathrm{E}-6 \\
2.3 \mathrm{E}-6 \\
1.0 \mathrm{E}-5 \\
9.6 \mathrm{E}-7 \\
1.4 \mathrm{E}-6 \\
3.0 \mathrm{E}-5\end{array}$ & $\begin{array}{l}\text { 4. } 2 \mathrm{E}-7 \\
4.7 \mathrm{E}-6 \\
6.6 \mathrm{E}-5 \\
1.0 \mathrm{E}-6 \\
1.8 \mathrm{E}-5 \\
2.0 \mathrm{E}-5 \\
1.8 \mathrm{E}-7 \\
8.2 \mathrm{E}-8 \\
7.6 \mathrm{E}-9 \\
1.1 \mathrm{E}-8 \\
1.1 \mathrm{E}-4\end{array}$ & $\begin{array}{l}5.7 \mathrm{E}-10 \\
7 . \mathrm{OE}-8 \\
2.1 \mathrm{E}-6 \\
3.2 \mathrm{E}-8 \\
7.8 \mathrm{E}-7 \\
6.1 \mathrm{E}-7 \\
7.0 \mathrm{E}-7 \\
1.1 \mathrm{E}-6 \\
9.9 \mathrm{E}-8 \\
1.4 \mathrm{E}-7 \\
5.6 \mathrm{E}-6\end{array}$ & $\begin{array}{l}7.8 \mathrm{E}-6 \\
5.2 \mathrm{E}-7 \\
1.5 \mathrm{E}-5 \\
2.4 \mathrm{E}-7 \\
5.8 \mathrm{E}-6 \\
4.5 \mathrm{E}-6 \\
5.4 \mathrm{E}-8 \\
8.7 \mathrm{E}-9 \\
7.7 \mathrm{E}-10 \\
1.1 \mathrm{E}-9 \\
3.4 \mathrm{E}-5\end{array}$ \\
\hline
\end{tabular}

$a_{\text {The dose }}$ is the average individual dose out to a distance of 55 miles from the plant.

$\mathrm{b}_{\text {An }}$ operating lifetime of 30 years is assumed. 
Table 7.15. Annual dose to the population ${ }^{\mathrm{a}}$ (resulting from long-lived radionuclides deposited on the ground during the lifetime ${ }^{b}$ of a model 1500-metric ton/year recycle uranium -- UF 6 plant) from the time of cessation of plant operation until significant decay of all radionuclides occurs

\begin{tabular}{ccccc}
\hline & \multicolumn{4}{c}{$\begin{array}{r}\text { Dose (person-rem or person-organ-rem } \\
\text { per } 3.6 \times 10^{6} \text { persons }\end{array}$} \\
\cline { 2 - 5 } Radionuclide & Total body & GI tract & Bone & Kidney \\
\hline Tc-99 & $6.1 \mathrm{E}-4$ & $1.2 \mathrm{E}-1$ & $1.5 \mathrm{E}-3$ & $2.8 \mathrm{E}-2$ \\
$\mathrm{U}-232$ & $1.0 \mathrm{E}-2$ & $2.8 \mathrm{E}-4$ & $1.9 \mathrm{E}-2$ & $2.1 \mathrm{E}-3$ \\
$\mathrm{U}-234$ & $5.4 \mathrm{E}-1$ & $1.9 \mathrm{E}-2$ & $2.7 \mathrm{E}-1$ & $6.2 \mathrm{E}-2$ \\
U-235 & $1.2 \mathrm{E}-1$ & $3.0 \mathrm{E}-4$ & $4.1 \mathrm{E}-3$ & $9.8 \mathrm{E}-4$ \\
$\mathrm{U}-236$ & $2.0 \mathrm{E}-1$ & $6.9 \mathrm{E}-3$ & $7.8 \mathrm{E}-2$ & $2.4 \mathrm{E}-2$ \\
$\mathrm{U}-238$ & $6.5 \mathrm{E}-3$ & $4.7 \mathrm{E}-3$ & $8.2 \mathrm{E}-2$ & $1.8 \mathrm{E}-2$ \\
Np-237 & $5.8 \mathrm{E}-3$ & $3.0 \mathrm{E}-5$ & $8.9 \mathrm{E}-3$ & $2.7 \mathrm{E}-3$ \\
Pu-238 & $3.3 \mathrm{E}-3$ & $2.8 \mathrm{E}-5$ & $3.6 \mathrm{E}-2$ & $4.0 \mathrm{E}-3$ \\
Pu-239 & $1.5 \mathrm{E}-4$ & $2.2 \mathrm{E}-8$ & $3.5 \mathrm{E}-3$ & $3.6 \mathrm{E}-4$ \\
Pu-240 & $3.6 \mathrm{E}-4$ & $3.3 \mathrm{E}-6$ & $5.1 \mathrm{E}-3$ & $5.1 \mathrm{E}-4$ \\
Total & $8.9 \mathrm{E}-1$ & $1.5 \mathrm{E}-1$ & $5.1 \mathrm{E}-1$ & $1.4 \mathrm{E}-1$
\end{tabular}

a Dose to the population is the sum of the individual doses out to a distance of 55 miles from the plant.

$\mathrm{b}_{\mathrm{A}}$ lifetime of 30 years is assumed for plant operation.

${ }^{c}$ Actual population within a 55 -mile radius of the midwestem plant site. 
Table 8.1. Annual cost for reduction of the radiological dose of the model 1500-metric ton/year recycle uranium -- UF plant

\begin{tabular}{llllll}
\hline & Case 1 & Case 2 & Case 3 & Case 4 & Case 5a \\
\hline Annual $\operatorname{cost}^{\mathrm{a}}(\$)$ & Base & $9.60 \mathrm{E}+4$ & $1.51 \mathrm{E}+5$ & $3.18 \mathrm{E}+5$ & $9.35 \mathrm{E}+5^{\mathrm{b}}$
\end{tabular}

Midwestern Site

Maximum annual individual dose at 1.5 miles

from airborne effluents, mrem

Total body
Bone
Lung
Kidney

Annual total population dose out to 55 miles from airborne effluents, person-rem

Total body
Bone

Bone

Kidney

Maximum annual individual dose at 1.5 miles from airborne effluents, mrem
Total body
Bone
Lung
Kidney

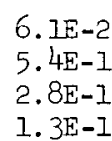

1. $3 \mathrm{E}-1$

$1.8 \mathrm{E}-2$
$1.6 \mathrm{E}-1$
$8.2 \mathrm{E}-2$
$3.8 \mathrm{E}-2$

\section{1. $2 \mathrm{E}-2$ \\ 1. IE-1}

$5.7 \mathrm{E}-2$

$1.2 \mathrm{E}-1$

$3.8 \mathrm{E}-2$

$5.6 \mathrm{E}-2$

$2.65 E-1$

1. $39 \mathrm{EOO}$

1. $14 \mathrm{E}+1$
$5.72 \mathrm{E} 00$

$2.83 \mathrm{E} 00$

$5.51 \mathrm{E}-1$
$4.52 \mathrm{E} 00$
$2.27 \mathrm{E} 00$
$1.12 \mathrm{E} 00$

3. 8IE-I

3. I $3 \mathrm{EOO}$

$1.57 \mathrm{E} 00$

$7.76 \mathrm{E}-1$

\section{Coastal Site}

2. $2 \mathrm{E}-2$

$1.9 \mathrm{E}-1$

$9.4 \mathrm{E}-2$
$4.6 \mathrm{E}-2$

$$
\begin{aligned}
& 1.5 \mathrm{E}-2 \\
& 1 \cdot 3 \mathrm{E}-1 \\
& 6.5 \mathrm{E}-2
\end{aligned}
$$

$3.2 E-2$

1. $O E-2$
8. $8 \mathrm{E}-2$
4. $4 \mathrm{E}-2$

4. $4 \mathrm{E}-2$

$8.4 \mathrm{E}-5$

1. $2 \mathrm{E}-1$

\begin{tabular}{|c|c|c|c|c|c|}
\hline Total body & $7.53 \mathrm{E}-1$ & $2.97 \mathrm{E}-1$ & $2.04 \mathrm{E}-1$ & $1.40 \mathrm{E}-1$ & $1.13 \mathrm{E}-3$ \\
\hline Bone & $6.38 \mathrm{E} 00$ & $2.51 \mathrm{E} 00$ & $1.72 \mathrm{EOO}$ & $1.18 \mathrm{E} 00$ & $9.51 \mathrm{E}-3$ \\
\hline Lung & $3.34 \mathrm{EOO}$ & $1.31 \mathrm{E0O}$ & $8.95 \mathrm{E}-1$ & $6.07 \mathrm{E}-1$ & $4.96 \mathrm{E}-3$ \\
\hline Kidney & $1.56 \mathrm{E} 00$ & $6.12 \mathrm{E}-1$ & $4.22 \mathrm{E}-1$ & $2.88 \mathrm{E}-1$ & $2.32 \mathrm{E}-3$ \\
\hline
\end{tabular}

Annual total population dose out to 55 miles

from airborne effluents, person-rem

Mid-1973 dollars; annual cost for radwaste treatment for each case with reference to Case 1 .

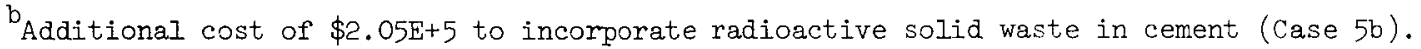

9.6 $\mathrm{E}-5$

$8.6 \mathrm{E}-4$

2. $1 \mathrm{E}-4$

$8.59 \mathrm{E}-3$

$\begin{array}{ll}1.09 \mathrm{E} 00 & 8.59 \mathrm{E}-3 \\ 5.39 \mathrm{E}-1 & 4.25 \mathrm{E}-3\end{array}$


Table 8.2. Annual cost increments, dose decrements, and cost/benefits between case studies at the model $1500-$ metric ton/year recycle uranium -- UF 6 plant

\begin{tabular}{|c|c|c|c|c|c|c|c|c|c|}
\hline \multirow{3}{*}{$\begin{array}{l}\text { Case } \\
\text { increment }\end{array}$} & \multirow{3}{*}{$\begin{array}{c}\text { Increase in } \\
\text { annual cost } \\
(\$ 1000)^{a}\end{array}$} & \multirow{2}{*}{\multicolumn{2}{|c|}{$\begin{array}{c}\text { Decrease in maximum } \\
\text { annual individual } \\
\text { dose at } 1.5 \text { miles } \\
\text { (mrem) }\end{array}$}} & \multirow{2}{*}{\multicolumn{2}{|c|}{$\begin{array}{c}\text { Decrease in annual dose } \\
\text { to population out to } \\
55 \text { miles } \\
\text { (person-rem) } \\
\end{array}$}} & \multicolumn{4}{|c|}{ Cost/benefit } \\
\hline & & & & & & \multicolumn{2}{|c|}{$\begin{array}{c}\text { Individual at } 1.5 \text { miles } \\
(\$ 1000 / \mathrm{mrem})\end{array}$} & \multicolumn{2}{|c|}{$\begin{array}{c}\text { Total population } \\
\text { within } 55 \text { miles } \\
\text { (\$1000/person-rem) } \\
\end{array}$} \\
\hline & & Total body & Bone & Total body & Bone & Total body & Bone & Total body & Bone \\
\hline \multicolumn{10}{|c|}{ Midwestern site } \\
\hline $\begin{array}{l}1 / 2 \\
2 / 3 \\
3 / 4 \\
4 / 5 a\end{array}$ & $\begin{array}{r}96 \\
55 \\
167 \\
617^{b}\end{array}$ & $\begin{array}{l}3.6 \mathrm{E}-2 \\
7.0 \mathrm{E}-3 \\
6.0 \mathrm{E}-3 \\
1.2 \mathrm{E}-2\end{array}$ & $\begin{array}{l}\text { 3. } 2 \mathrm{E}-1 \\
6 . \mathrm{OE}-2 \\
5 . \mathrm{OE}-2 \\
1.1 \mathrm{E}-1\end{array}$ & $\begin{array}{l}8.4 \mathrm{E}-1 \\
1.7 \mathrm{E}-1 \\
1.2 \mathrm{E}-1 \\
2.6 \mathrm{E}-1\end{array}$ & $\begin{array}{l}6.9 \mathrm{EOO} \\
1.4 \mathrm{EOO} \\
9.6 \mathrm{E}-1 \\
2.1 \mathrm{E} 00\end{array}$ & $\begin{array}{l}2.7 \mathrm{E}+3 \\
7.8 \mathrm{E}+3 \\
2.8 \mathrm{E}+4 \\
5.1 \mathrm{E}+4\end{array}$ & $\begin{array}{l}3 \cdot 0 \mathrm{E}+2 \\
9.2 \mathrm{E}+2 \\
3 \cdot 3 \mathrm{E}+3 \\
5.6 \mathrm{E}+3\end{array}$ & $\begin{array}{l}1.1 \mathrm{E}+2 \\
3 \cdot 2 \mathrm{E}+2 \\
1.4 \mathrm{E}+3 \\
2.4 \mathrm{E}+3\end{array}$ & $\begin{array}{l}1 \cdot 4 \mathrm{E}+1 \\
3 \cdot 9 \mathrm{E}+1 \\
1.7 \mathrm{E}+2 \\
2 \cdot 9 \mathrm{E}+2\end{array}$ \\
\hline \multicolumn{10}{|c|}{ Coastal site } \\
\hline $\begin{array}{l}1 / 2 \\
2 / 3 \\
3 / 4 \\
4 / 5 a\end{array}$ & $\begin{array}{l}96 \\
55 \\
167 b \\
617\end{array}$ & $\begin{array}{l}\text { 3. } 3 E-2 \\
7 . O E-3 \\
5 . O E-3 \\
1 . O E-2\end{array}$ & $\begin{array}{l}2.8 \mathrm{E}-1 \\
6.0 \mathrm{E}-2 \\
4.2 \mathrm{E}-2 \\
8.7 \mathrm{E}-2\end{array}$ & $\begin{array}{l}4.6 \mathrm{E}-1 \\
9.3 \mathrm{E}-2 \\
6.4 \mathrm{E}-2 \\
1.4 \mathrm{E}-1\end{array}$ & $\begin{array}{l}3.9 \mathrm{E} 00 \\
7.9 \mathrm{E}-1 \\
5.4 \mathrm{E}-1 \\
1.1 \mathrm{E} 00\end{array}$ & $\begin{array}{l}2 \cdot 9 \mathrm{E}+3 \\
7 \cdot 8 \mathrm{E}+3 \\
3 \cdot 3 \mathrm{E}+4 \\
6.2 \mathrm{E}+4\end{array}$ & $\begin{array}{l}3 \cdot 4 \mathrm{E}+2 \\
9 \cdot 2 \mathrm{E}+2 \\
4.0 \mathrm{E}+3 \\
7.1 \mathrm{E}+3\end{array}$ & $\begin{array}{l}2.1 \mathrm{E}+2 \\
5.9 \mathrm{E}+2 \\
2.6 \mathrm{E}+3 \\
4.4 \mathrm{E}+3\end{array}$ & $\begin{array}{l}2.5 \mathrm{E}+1 \\
6.9 \mathrm{E}+1 \\
3 \cdot 1 \mathrm{E}+2 \\
5.6 \mathrm{E}+2\end{array}$ \\
\hline
\end{tabular}

Mid-1973 dollars.

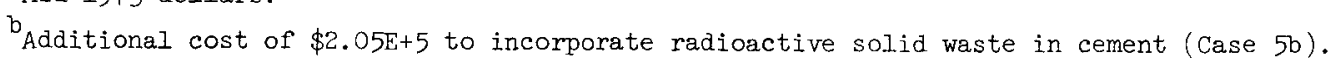


Table 8.3. Annual cost for reduction of dose from airborne effluents at the model 1500-metric ton/year recycle uranium -- UF 6 plant -- dust control system ${ }^{2}$

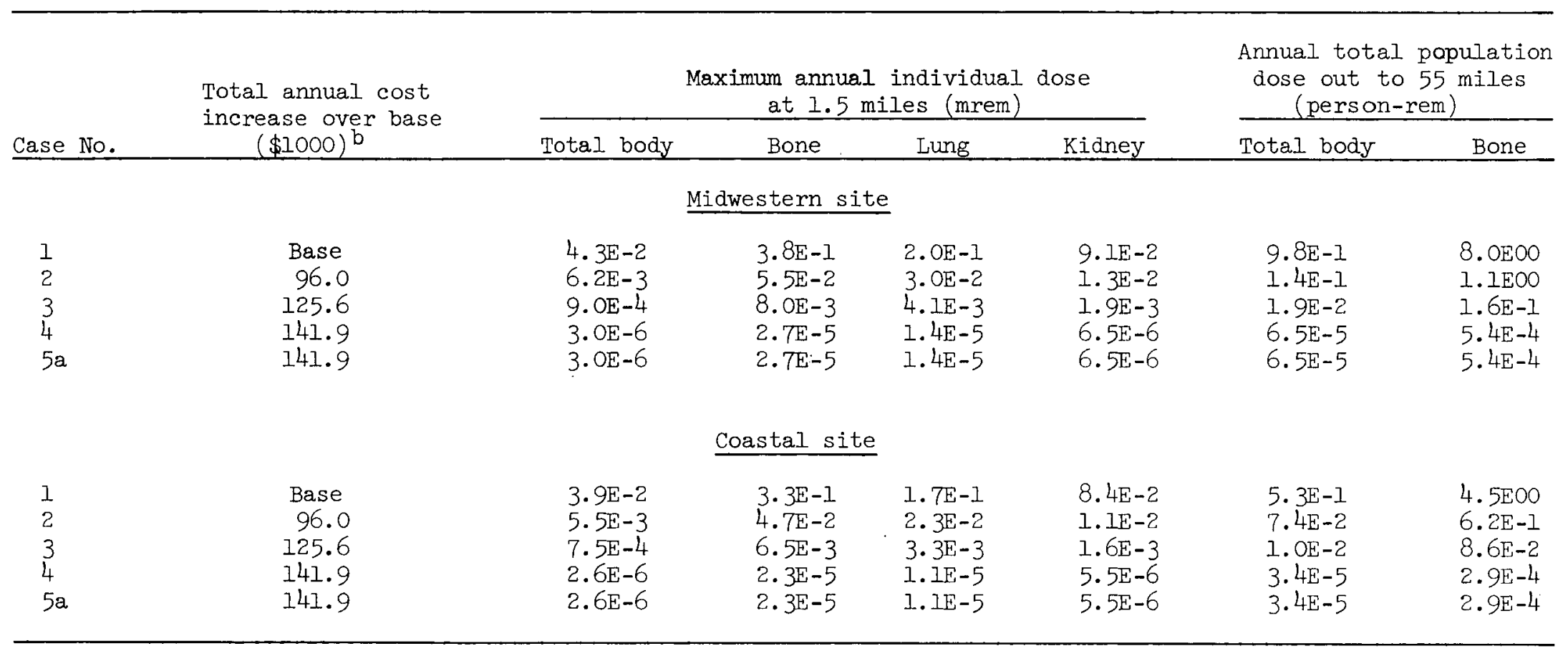

Dust control system exclusive of other systems.

$\mathrm{b}_{\text {Mid-1973 dollars. }}$ 
Table 8.4. Annual cost for reduction of dose from airborne effluents at the model 1500 -metric ton/year recycle uranium -- $\mathrm{UF}_{6}$ plant -- process off-gas ${ }^{a}$

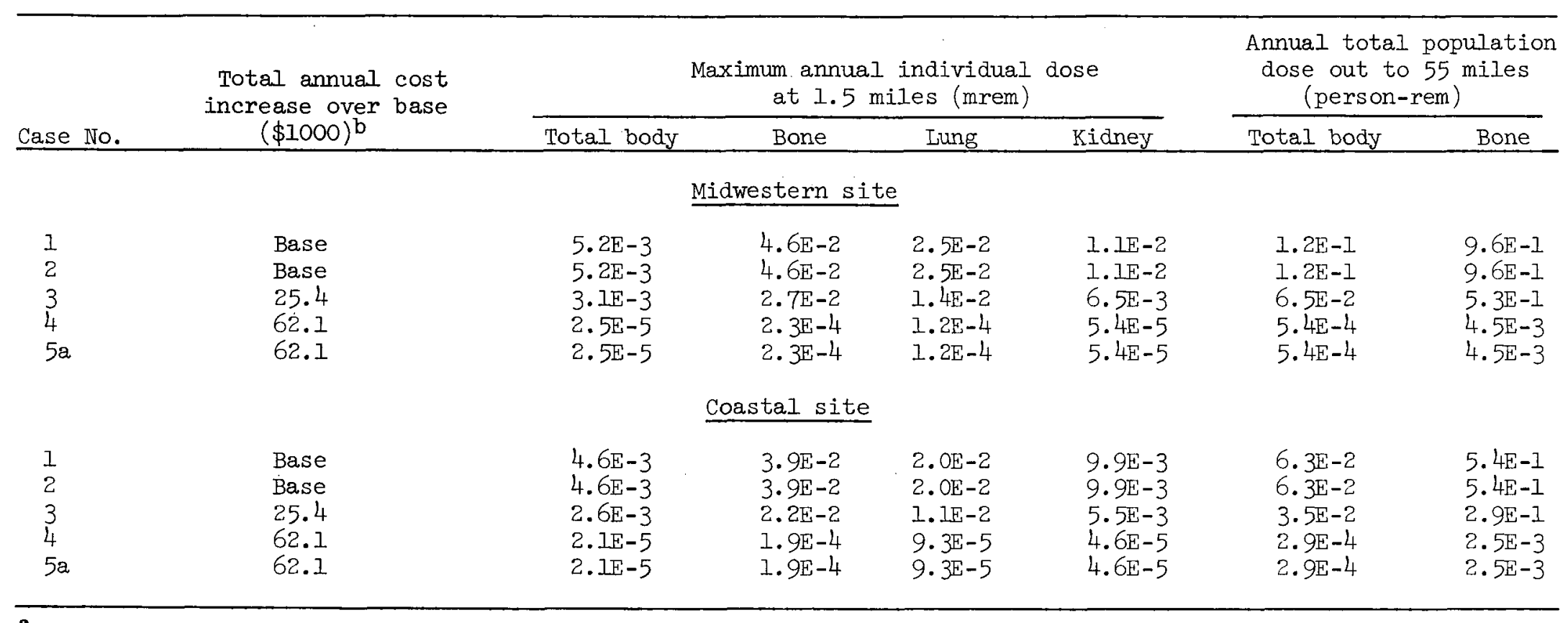

${ }^{a}$ Process off-gas system exclusive of other systems.

bid-1973 dollars. 
Table 8.5. Annual cost for reduction of dose from airborne effluents at the model $1500-$ metric ton/year recycle uranium -- $\mathrm{UF}_{6}$ plant -- building ventilation effluent ${ }^{2}$

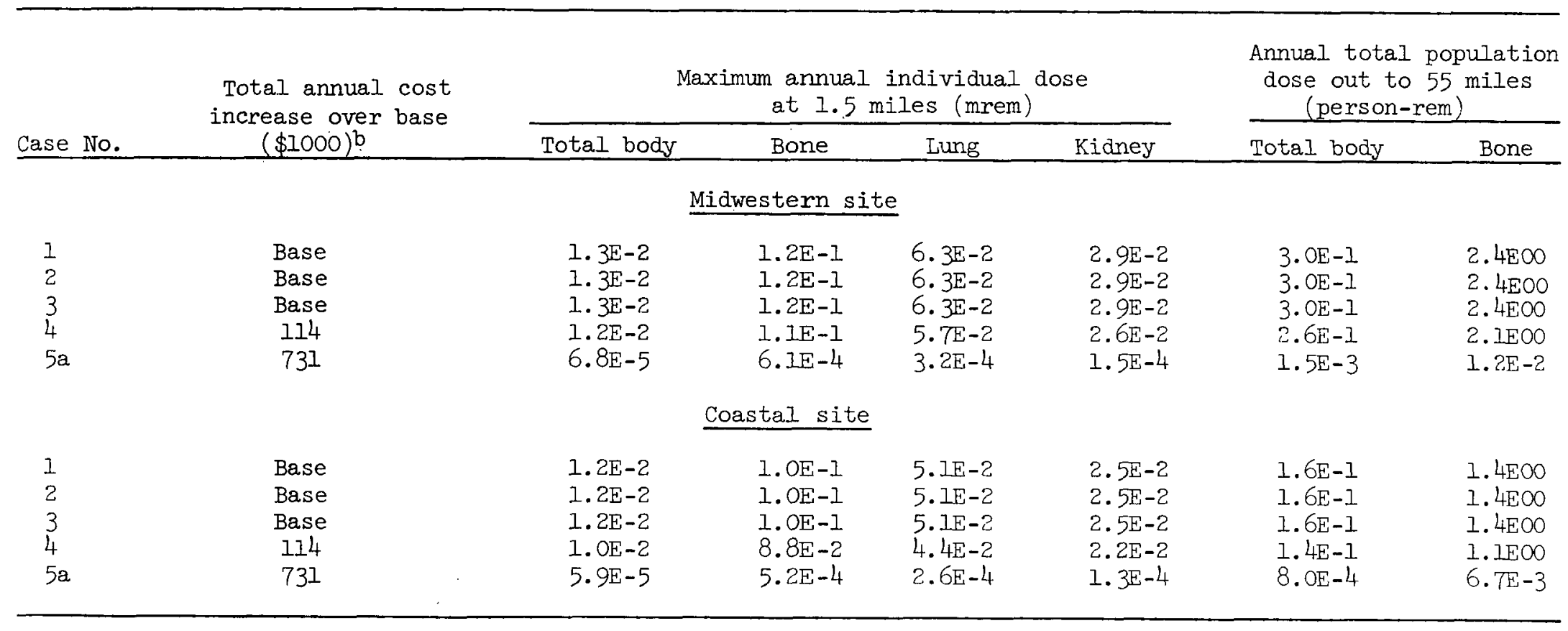

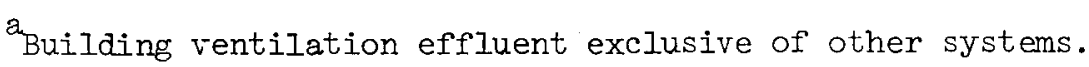

$b_{\text {Mid-1973 dollars. }}$ 
ORNL-OWG 76-1053

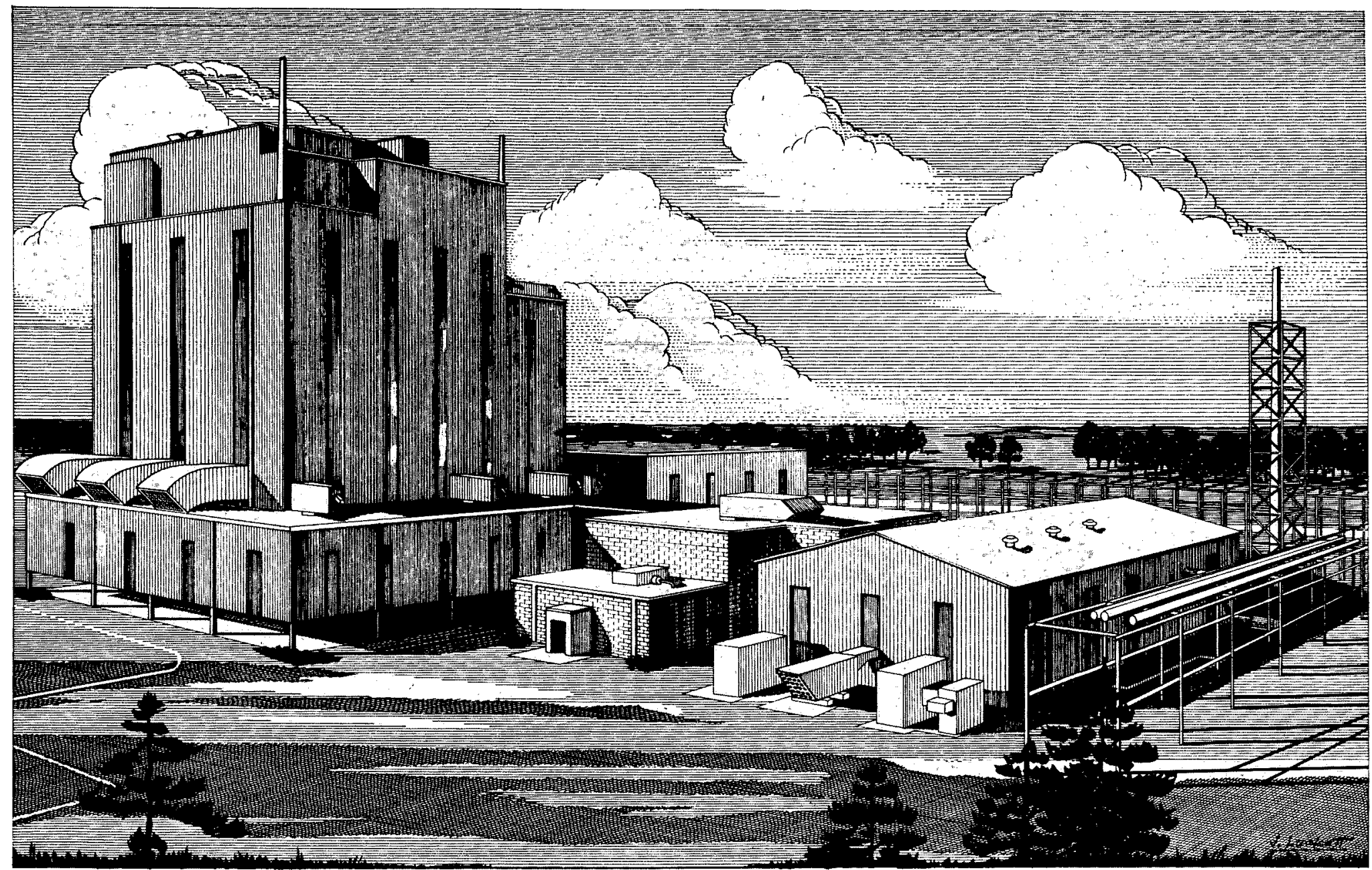

Fig. 3.1. Artist's conception of the $\mathrm{UF}_{6}$ facility constructed by Allied-General Nuclear Services near Barnwell, South Carolina. 
ORNL DWG $76-1014$

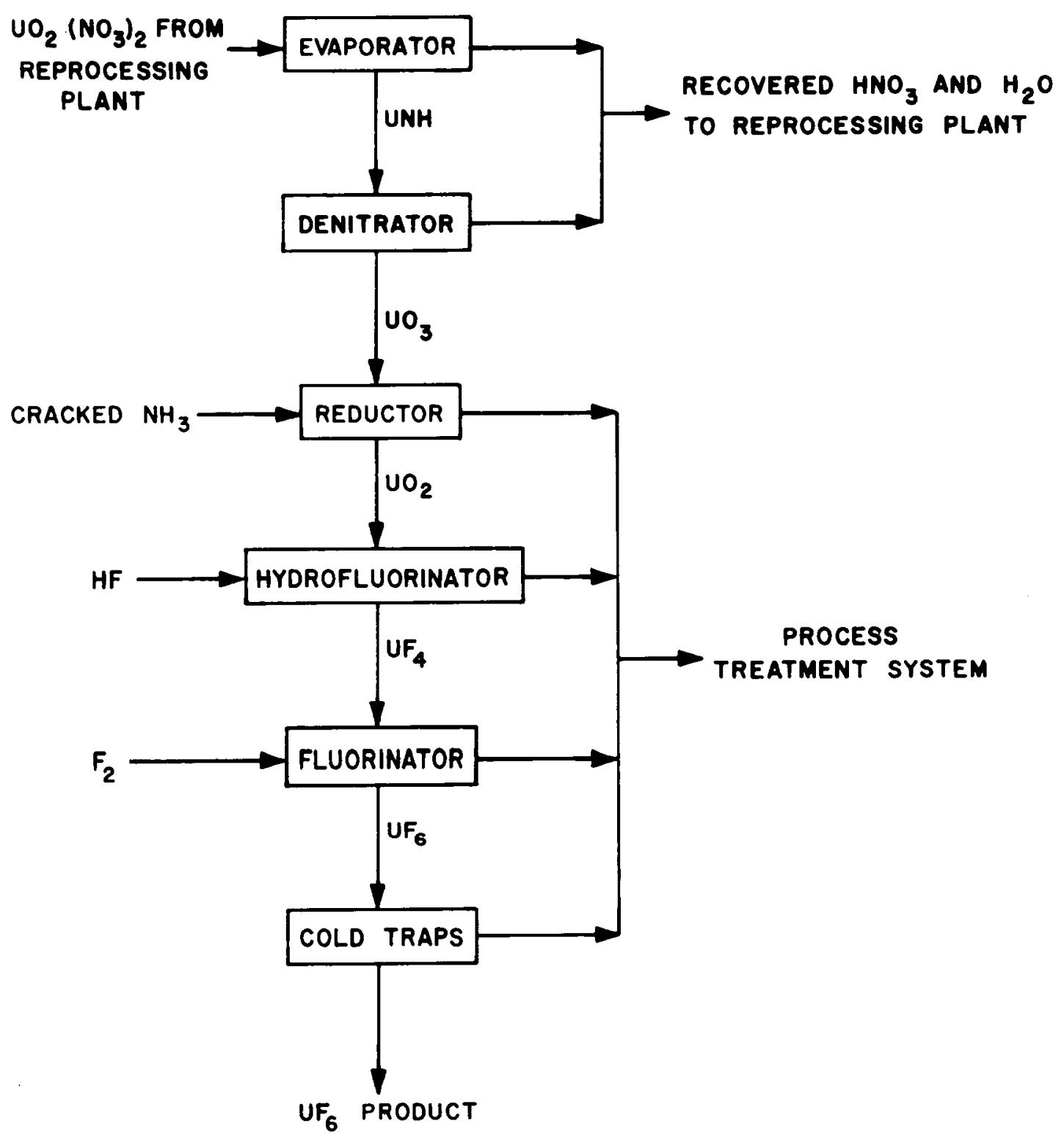

Fig. 3.2. Simplified flow diagram for the uranium hexafluoride process. 


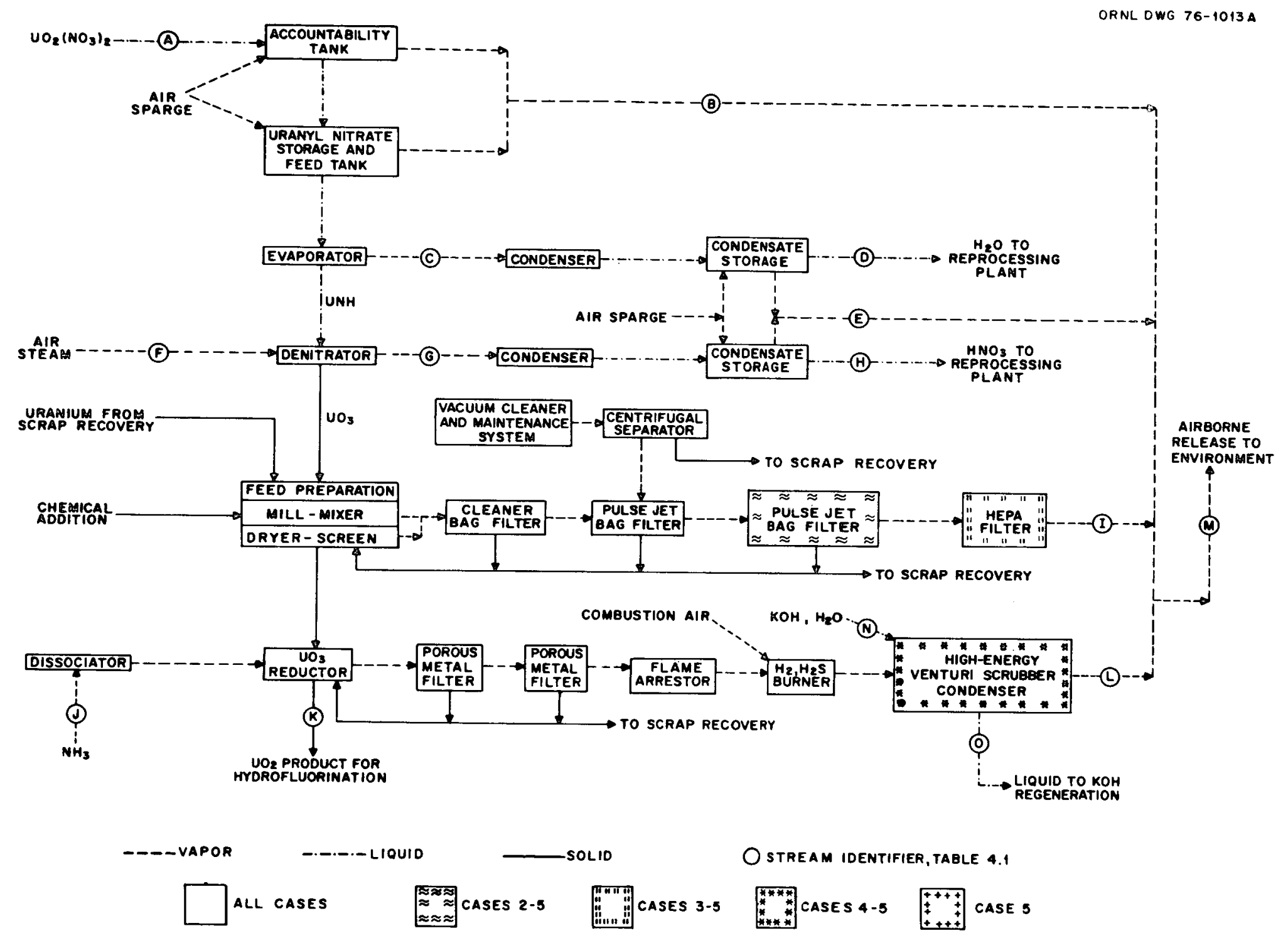

Fig. 4.1. Process and waste treatment system for the production of uranium dioxide from uranyl nitrate. 


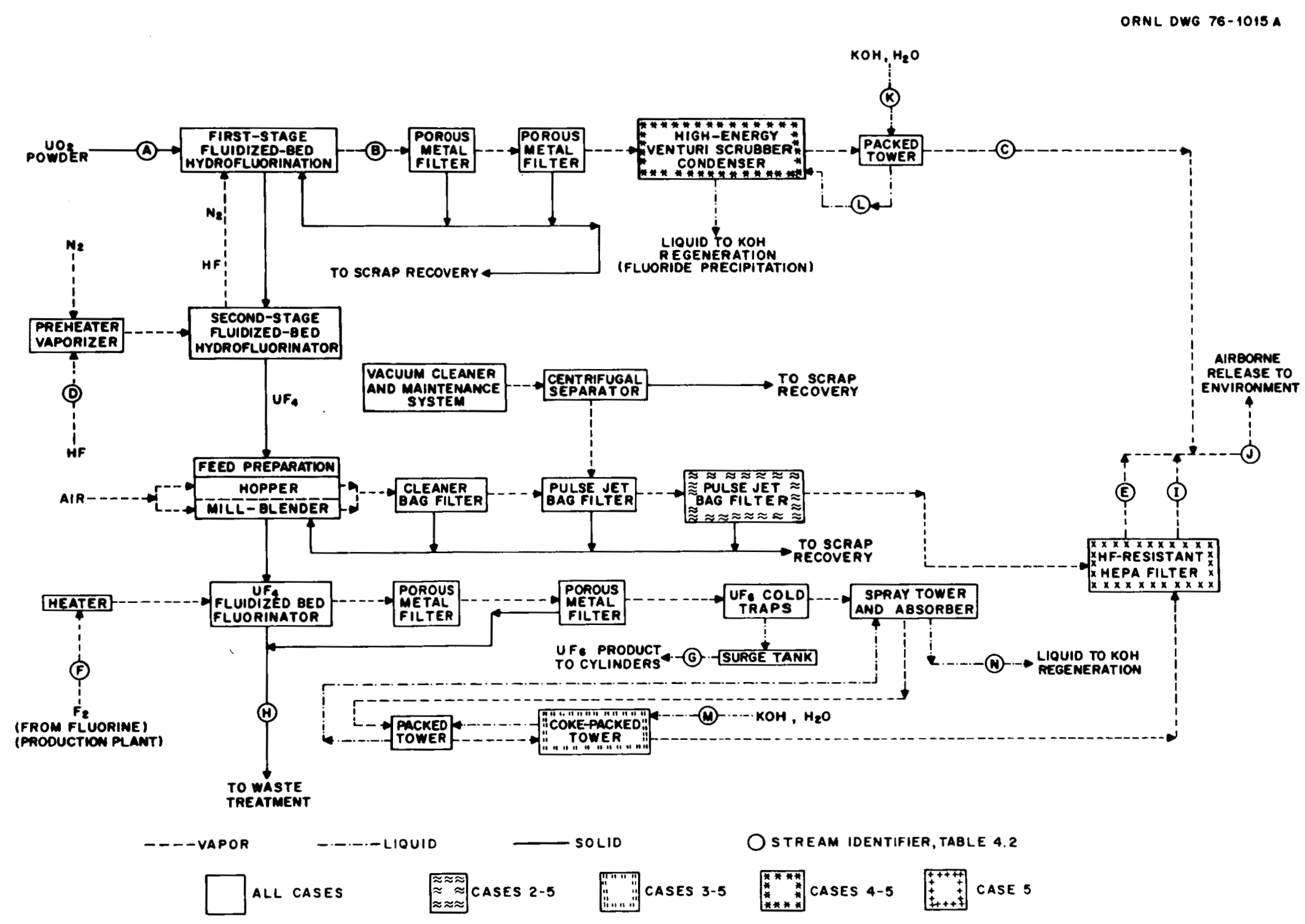

Fig. 4.2. Process and waste treatment system for the production of uranium hexafluoride from uranium dioxide. 


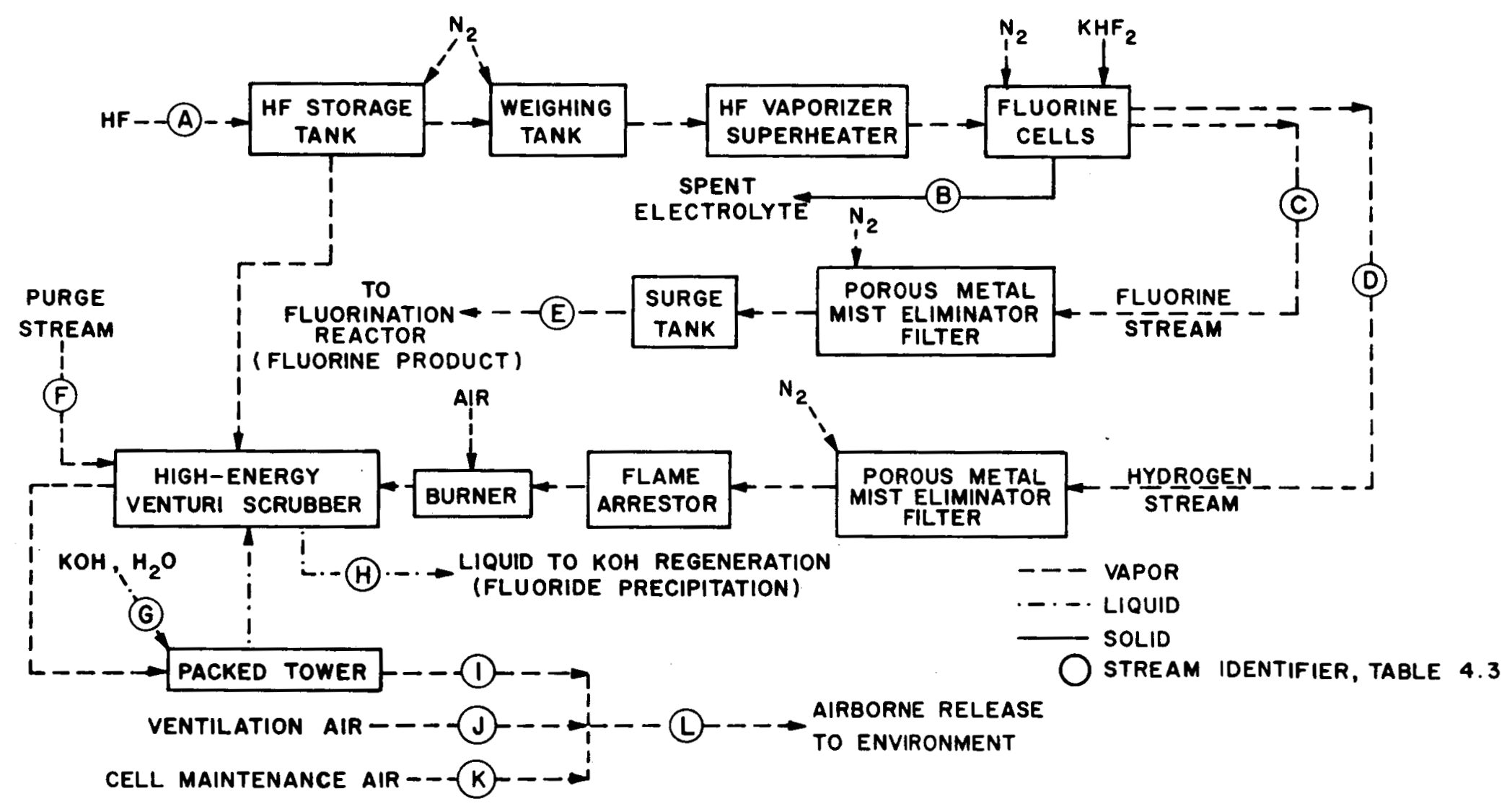

Fig. 4.3. Process and waste treatment system for the production of fluorine. 


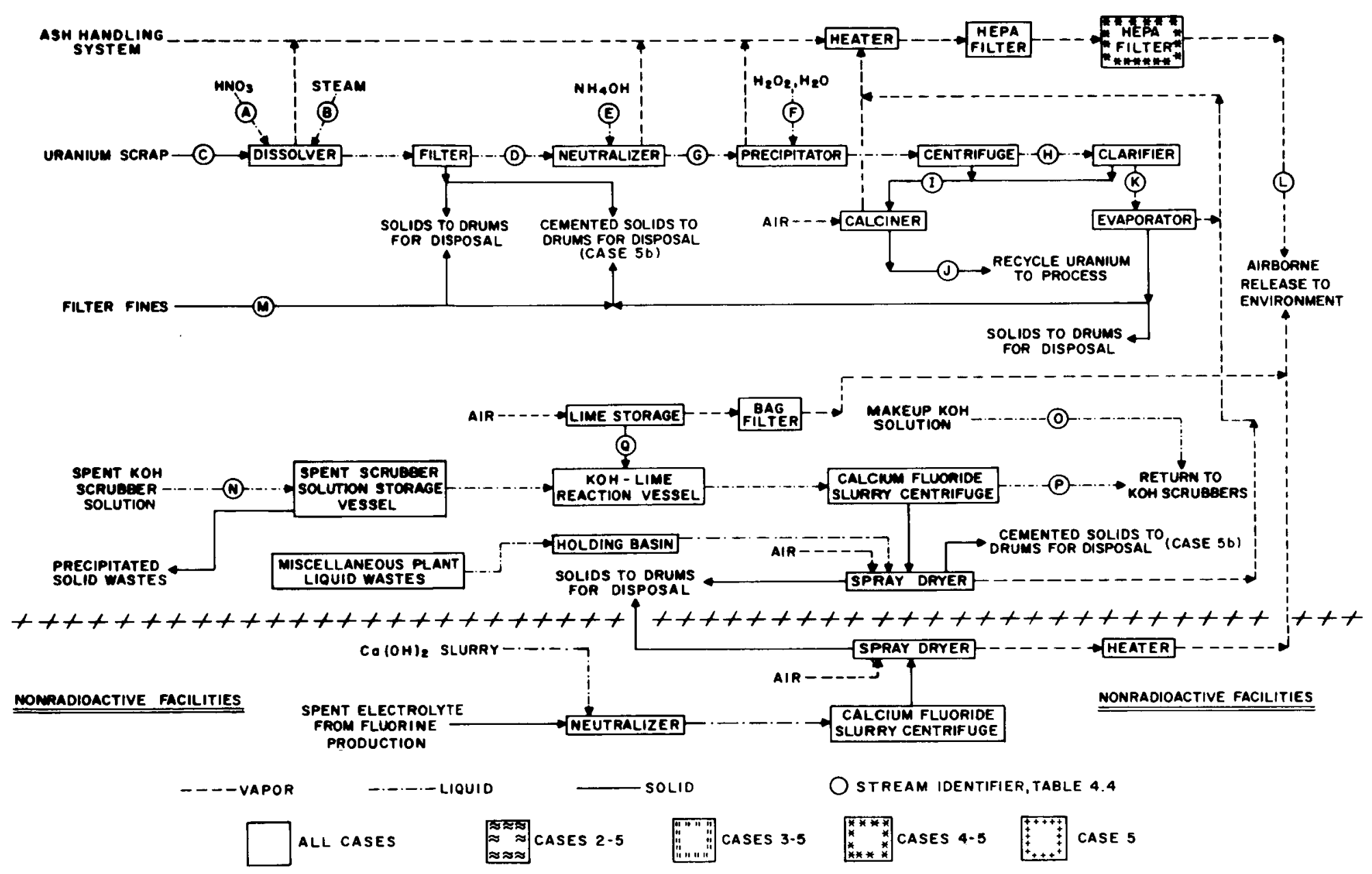

Fig. 4.4. Process and waste treatment system for the scrap recovery process. 


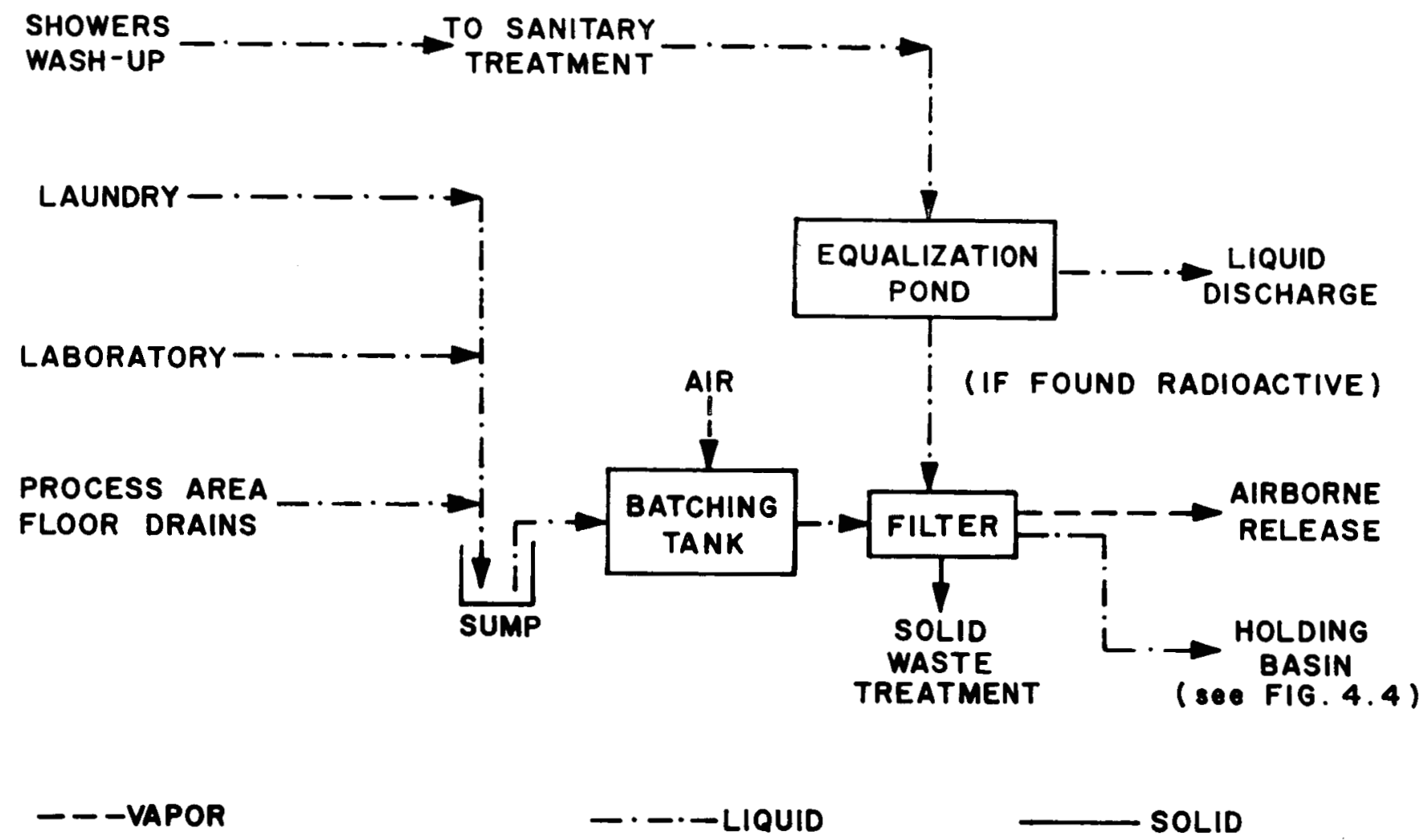

Fig. 4.5. Miscellaneous liquid waste treatment system. 


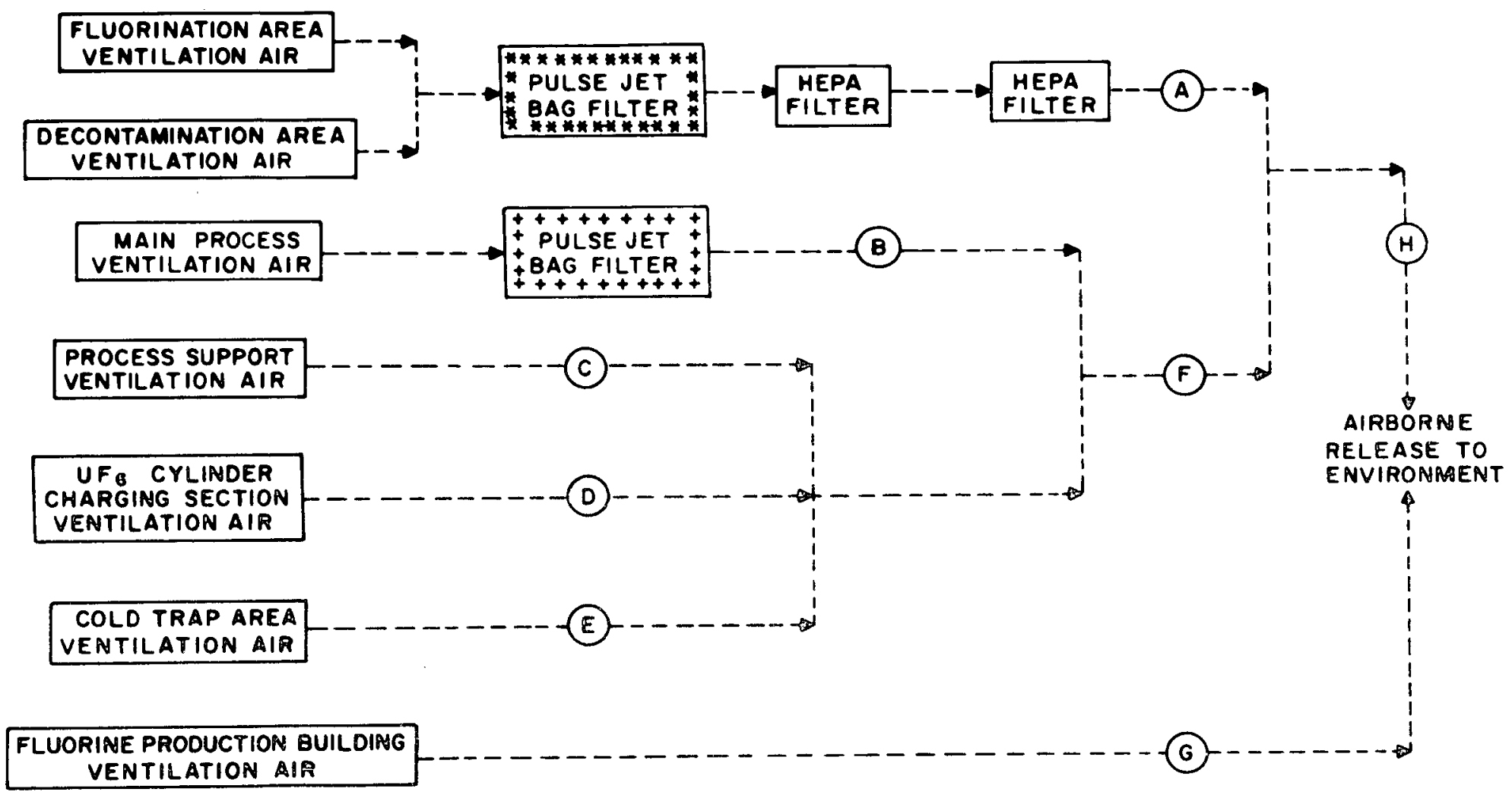



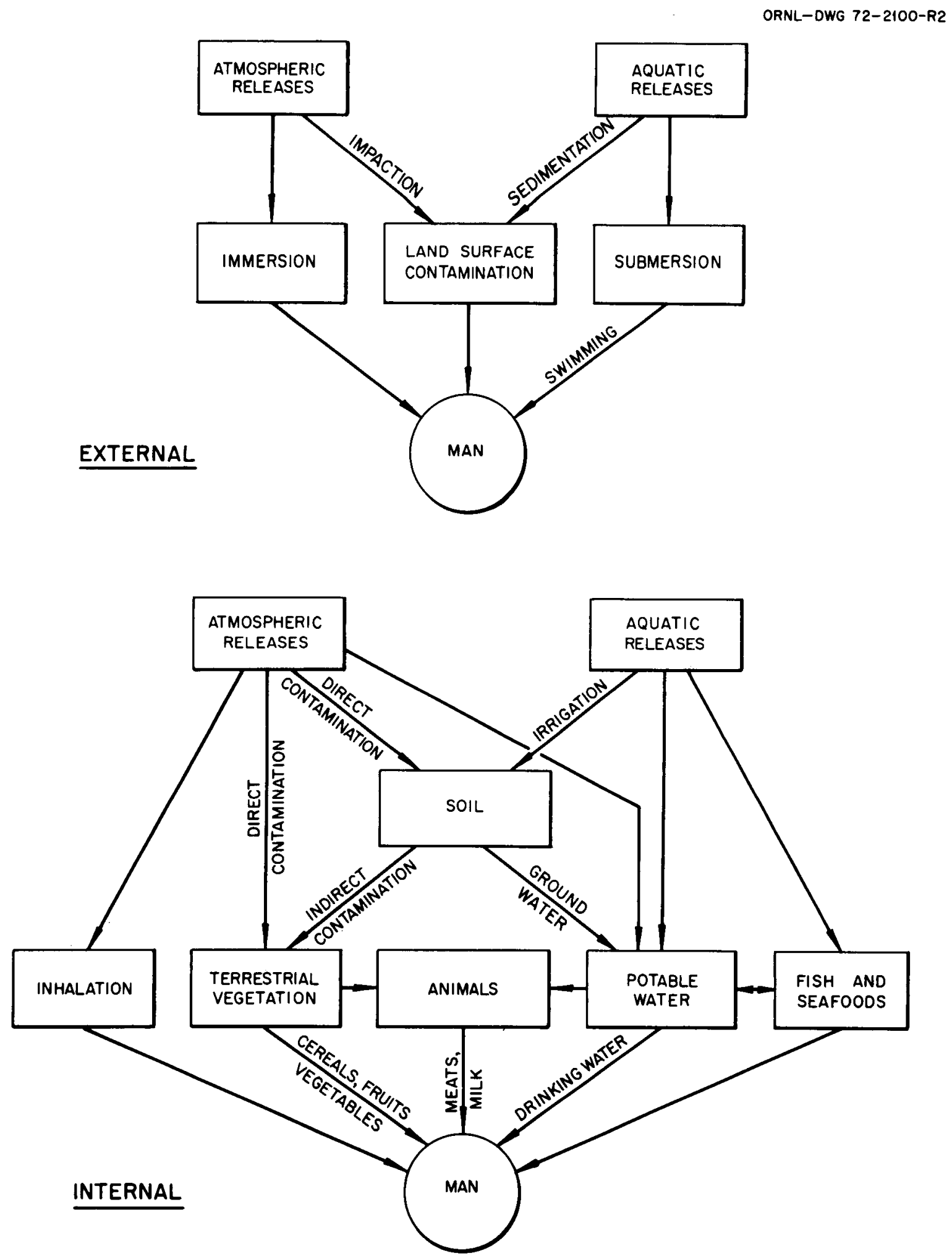

Fig. 7.1. Pathways for external and internal exposure of man. 
ORNL DWG 76-1079A

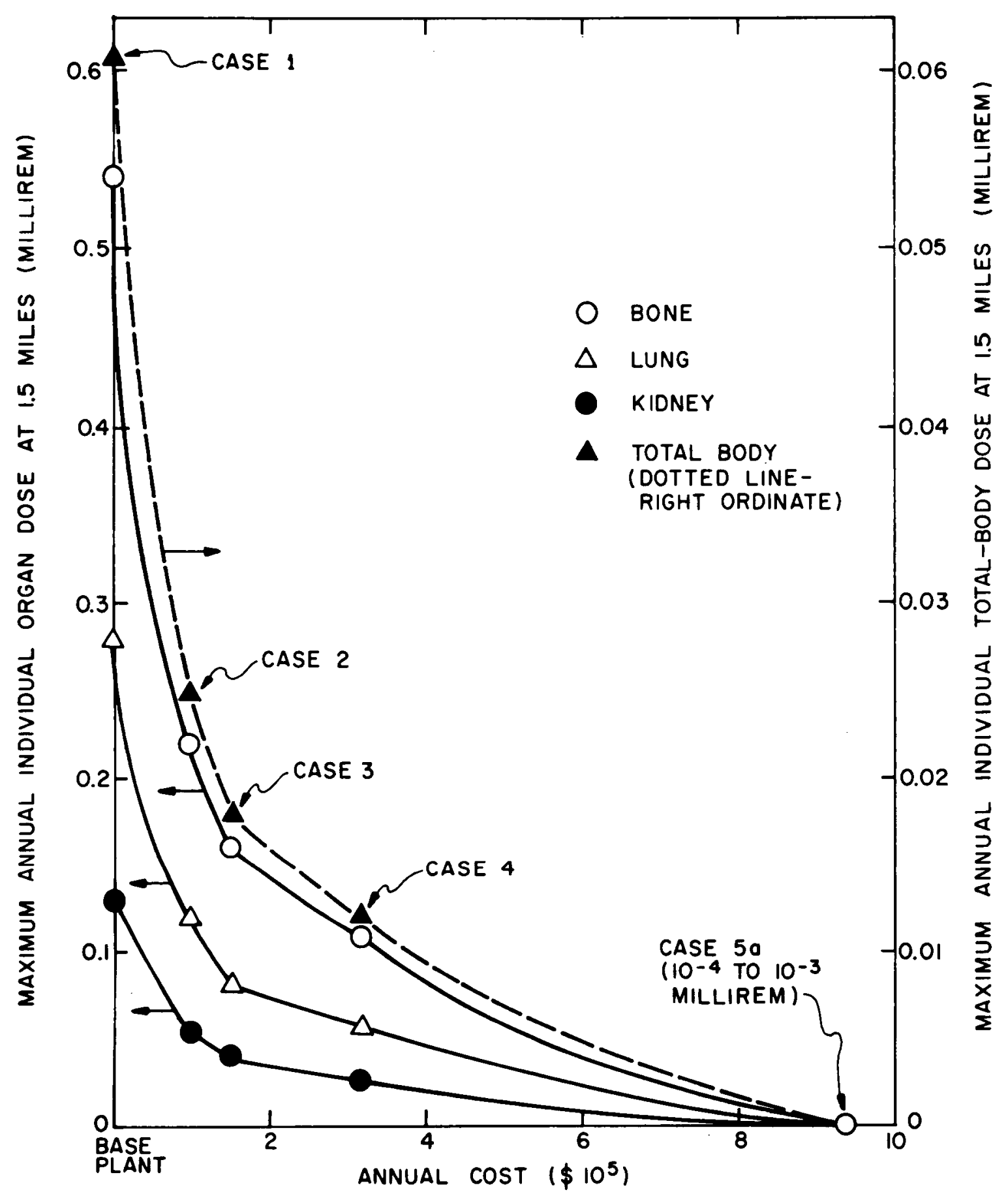

Fig. 8.1. Annual cost for reduction of maximum annual individual organ and total-body doses from airborne effluents at 1.5 miles from the model recycle uranium - UF 6 plant. (Doses are for the midwestern location.) 


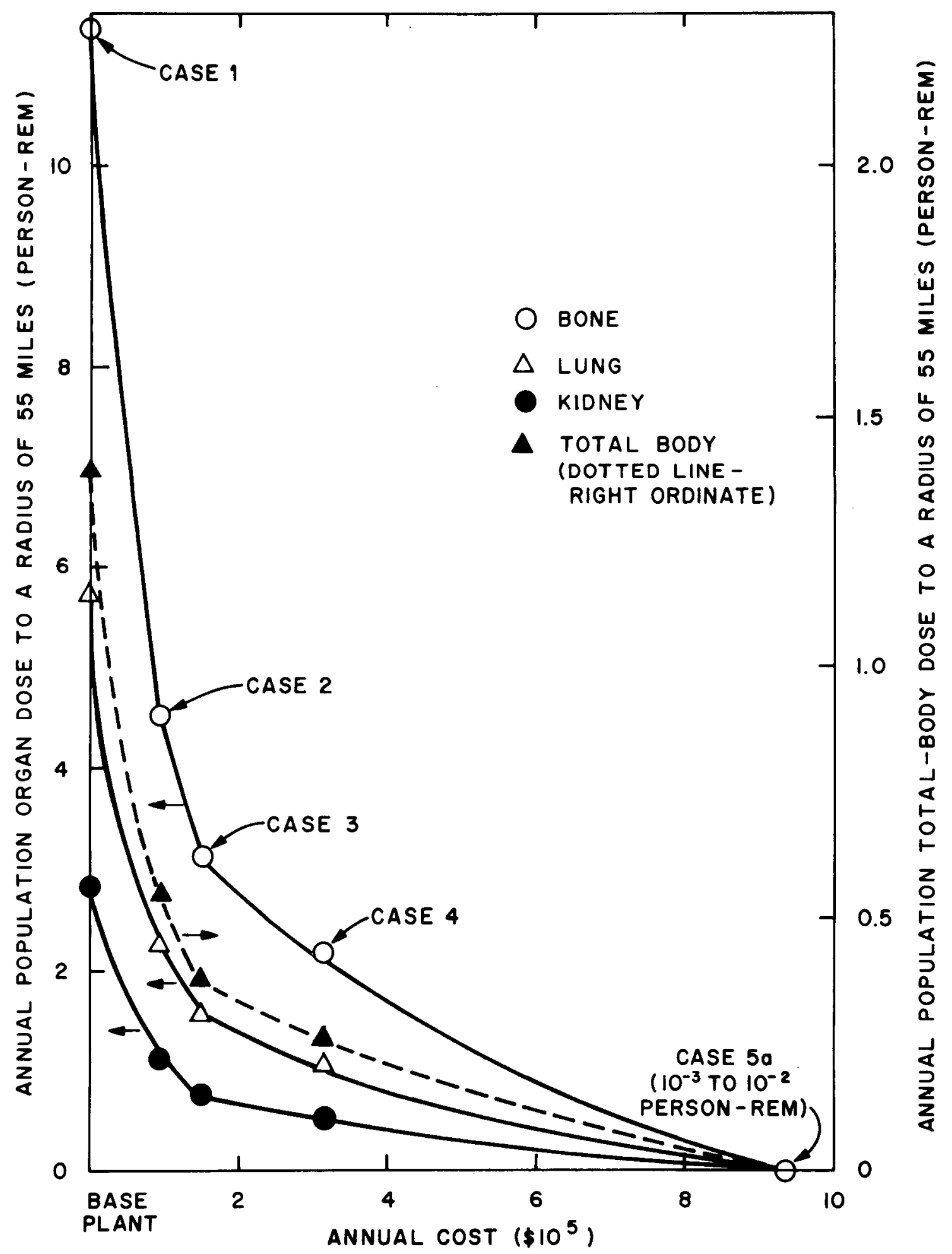

Fig. 8.2. Annual cost for reduction of annual population individual organ and total-body doses out to a radius of 55 miles from the model recycle uranium - UF 6 plant. (Doses are for the midwestern location). 


\section{APPENDIX A. PREPARATION OF COST ESTIMATES}

\subsection{INTRODUCTION}

This appendix presents the details of the methods used to estimate the capital and annual costs of the radioactive waste treatment cases for the model 1500 -metric ton/year recycle $\mathrm{UF}_{6}$ plant. The details of the methods used for estimating the annual fixed charges, annual operating costs, total annual costs, and contribution to reprocessing and power cost are presented in Sect. 6.0 of the survey report. In summary, the capital cost is the sum of the direct cost (complete installation cost of the equipment and additional structure required) and the indirect cost, and the annual cost is the sum of the annual fixed charge (26\% of the capital cost) and the annual operating and maintenance cost.

All costs are based on new construction costs where all of the equipment that is added for each case study is included in an integrated plant. Backfitting costs for existing plants are not considered. The costs of storing drums of solid waste onsite or shipping offsite for storage or burial are not included. The costs for radioactive waste treatment Cases 2 through $5 \mathrm{~b}$ are presented in Table A-1.

\subsection{Capital Costs}

The capital cost of each radioactive waste treatment case is the sum of the direct and indirect costs. The methods used for estimating the direct and indirect costs are presented in the following sections.

\subsubsection{Direct costs}

The major equipment components were sized and a base cost estimated. The base cost for the conventional chemical equipment, such as packed towers, tankage, pumps, etc., is estimated based on general methods for costing equipment for conceptual designs. Appropriate factors are applied to the equipment cost to estimate the cost of installation, piping, instruments and controls, and electrical. ${ }^{1-3}$ The base cost for the particulate removal equipment, venturi scrubbers, and bag filters is the complete installed cost, and it is estimated using published information. ${ }^{4-7}$ The cost for the HEPA filters is based on experience at ORNL. ${ }^{8-10}$

Structural requirements are estimated using equipment size and allowing for auxiliary equipment for Cases 2, 3, and 4; however, it is assumed that the building ventilation bag filters in Case 5a are installed exterior to the main structure in a self-contained housing and the cost of an additional structure is not required. The cost of a warehouse and related facilities is not included. The total direct cost for each treatment case is the sum of the installed equipment (material and labor) cost and the cost of the structure where applicable. 


\subsubsection{Indirect costs}

Indirect costs are estimated as follows:

Percentage of Direct Cost

Engineering and supervision $\quad 15$

Construction expense and contractor's fee 20

Engineering design (A-E) 15

Contingency 45

Other owner's cost 10

Interest 35

Total

\begin{tabular}{l}
15 \\
5 \\
5 \\
4 \\
0 \\
35 \\
\hline 40
\end{tabular}

The interest during construction and the contingency allowance are included as indirect costs to simplify the calculations. Interest is applied to the cumulative total cost at the rate of $8 \%$ per year over a 5 -year cash flow expenditure period.

\subsubsection{Method of estimating costs}

Radioactive Waste Treatment Case 2. Case 2 consists of installing a 5300-scfm pulse jet bag filter in the $\mathrm{UO}_{3}$ feed preparation off-gas system (Fig. 4.1) and a 1800-scfm pulse jet bag filter in the $\mathrm{UF}_{4}$ feed preparation off-gas system (Fig. 4.2).

The installed cost of the pulse jet bag filters is estimated based on the method used in ref. 6, assuming that the cost of a pulse jet bag filter is 1.1 times the cost of a reverse jet bag filter.

$5300 \mathrm{scfm}$ is equivalent to $7800 \mathrm{cfm}$ at $70^{\circ} \mathrm{F}$.

The 1965 estimated installed cost of a 60,000 -cfm reverse jet bag filter was $\mathcal{L} 73,000$ which, at $\$ 2.80 / \mathcal{L}$, is equivalent to $\$ 204,000$ (Table IX, ref. 4).

The escalation factor from 1965 to March $1973=(141.0-$

$104.2) / 104.2=36.8 / 104.2=35.3 \%$

The estimated installed cost of a 7800-cfm unit $=$

$1.1 \times(7800 / 60,000)^{0.6} \times \$ 204,000 \times 1.353=\$ 89,300$

It is estimated, based on the equipment size, ${ }^{11}$ that a structural area of $180 \mathrm{ft}^{2}$ costing $\$ 22 / \mathrm{ft}^{2}$ is required, resulting in a structure cost of $\$ 4000 .^{2}$

The annual operating and maintenance (O\&M) cost is estimated based on information presented in ref. 7, p. 1147, for 1974.

The calculations are as follows: 
The annual O\&M cost for a bag filter handling 70,000 scfm at $250^{\circ} \mathrm{F}$ is $\$ 15,750$ (ref. 7).

The annual O\&M cost for a 7800-cfm bag filter is as follows:

$70,000 \mathrm{scfm}$ at $250^{\circ} \mathrm{F}=52,300 \mathrm{cfm}$ at $70^{\prime \prime} \mathrm{F}$

$(7800 / 52,300)^{0.6} \times \$ 15,750 \times 0.94=\$ 4700(1973$ dollars $)$

Building: Assume $0.05 \times \$ 4000=\$ 200$

Total O\&M $=\$ 4900$

The installed cost and annual O\&M cost for the 1800-scfm bag filter is estimated in a similar manner.

$1800 \mathrm{scfm}=2637 \mathrm{cfm}$ at $70^{\circ} \mathrm{F}($ Use $2600 \mathrm{cfm})$

Installed cost: $1.1 \times(2600 / 60,000)^{1.6} \times \$ 20,400 \times 1.353=\$ 46,300$

Structure cost: $100 \mathrm{ft}^{2}$ at $\$ 22 / \mathrm{ft}^{2}=\$ 2200$

Total $=\$ 48,500$

Annual O\&M: $(2799 / 52,300)^{10.6} \times \$ 15,750 \times 0.94=\$ 2500$

The complete costs for Case 2 are as follows:

Direct Cost:

Installed equipment $=\$ 135,600$

Structure $=\$ 6,200$

Total $=\$ 141,800($ Use $\$ 142,000)$

Indirect Cost:

$\$ 142,000 \times 1.4=\$ 198,800($ Use $\$ 199,000)$

Capital Cost:

$\$ 142,000+\$ 199,000=\$ 341,000$

Annual Fixed Charge:

$\$ 341,000 \times 0.26=\$ 88,660$ (Use $\$ 89,000$ )

Annual O\&M:

$\$ 4900+\$ 2500=\$ 7400$

Total Annual Cost:

$\$ 89,000+\$ 7400=\$ 96,400($ Use $\$ 96,000)$

Radioactive waste treatment Case 3. Case 3 includes Case 2 with the addition of a 5300-scfm-capacity HEPA filter installation in the $U_{3}$ feed preparation off-gas system (Fig. 4.1) and an 8-scfm-capacity coke-packed tower in the $U_{4}$ fluidized-bed fluorinator off-gas system (Fig. 4.2). 
The cost estimate for the HEPA filter installation is based on the cost of a $16,000-\mathrm{cfm}$ system installed at ORNL in April 1973..$^{810}$

$5300 \mathrm{scfm}$ with a 1.36 safety factor $=5300 \times 530 / 492 \times 1.36$

$=7764 \mathrm{cfm}$ at $70^{\circ} \mathrm{F}$

A $8000-\mathrm{cfm}$ system is costed. The installed cost of the ORNL system including filter housing, SST ductwork, fans, filters, dampers, instrumentation, and electrical was $\$ 62,000$.

Estimated cost of a 8000-cfm system $=\$ 62,000(8000 / 16,000)^{1.6 t}=\$ 40,900$

Building: $140 \mathrm{ft}^{2}$ at $\$ 22 / \mathrm{ft}^{2}=\$ 3100$

Total $=\$ 44,000$

\section{Annual O\&M:}

Fan power: $20 \mathrm{hp} \mathrm{x} \$ 40 / \mathrm{yr}-\mathrm{hp} \times 0.85=\$ 680$

Filter testing twice per year: $\$ 30 \times 2=\$ 60$

Filter replacement every 2 years: $\$ 700 / 2=\$ 350$

Maintenance: Estimated at 3\% of equipment and building cost

$$
=0.03 \times \$ 44,000=\$ 1320
$$

Total $=\$ 2410($ Use $\$ 2400)$

The cost of the coke-packed tower is estimated as follows:

Assume that the tower is a 6 -ft-diam $\times 20$-ft-high rubber-lined mild-steel tank with $15 \mathrm{ft}$ of activated charcoal as packing. The 1968 purchase price of the tower based on information presented in ref. 2, a field installation factor of 1.9 , and an escalation factor of $6 \%$ per year for 5 years results in an installed cost of the tower as follows:

$$
\begin{aligned}
& \$ 8000 \times 1.9 \times 1.06^{5}=\$ 20,300 \\
& \text { Area of tower }=[(0.7854 \times 36)+(\pi \times 6 \times 20)]=434 \mathrm{ft}^{2} \\
& \text { Cost of lining }=434 \mathrm{ft}^{2} \times \$ 4 / \mathrm{ft}^{2}=\$ 1736(\mathrm{use} \$ 1700) \\
& \text { Cost of charcoal }=\left(0.7854 \times 6^{2} \times 15\right)\left(24 \mathrm{lb} / \mathrm{ft}^{3}\right)(\$ 1.10 / \mathrm{lb})=\$ 11,200 \\
& \text { Total installed cost of tower }=\$ 33,200
\end{aligned}
$$

The cost of two 5-gpm centrifugal pumps based on information in ref. 2 is $\$ 860$. Using an installation factor of 2.4 and escalation of $6 \%$ for 5 years, the total direct cost is as follows:

$\$ 860 \times 2.4 \times 1.06^{5}=\$ 2762($ Use $\$ 2800)$

Building: $144 \mathrm{ft}^{2}$ at $\$ 22 / \mathrm{ft}^{2}=\$ 3200$

Total direct cost $=\$ 39,200$

The annual O\&M cost is estimated at $3 \%$ of direct cost: $0.03 \times \$ 39,200=\$ 1200$

The complete costs for Case 3 are as follows:

Direct Cost: 
Installed equipment $=\$ 212,500$

Structure $=\$ 12,500$

Total $=\$ 225,000$

Indirect Cost:

$\$ 225,000 \times 1.4=\$ 315,000$

Capital Cost:

$\$ 225,000+\$ 315,000=\$ 540,000$

Annual Fixed Charge:

$\$ 540,000 \times 0.26=\$ 140,400$ (Use $\$ 140,000)$

Annual O\&M:

$\$ 4900+\$ 2500+\$ 2400+\$ 1200=\$ 11,000$

Total Annual Cost:

$\$ 140,000+\$ 11,000=\$ 151,000$

Radioactive Waste Treatment Case 4. Case 4 includes Case 3 with the addition of the following equipment:

1. 128-scfm high-energy venturi scrubber-condenser in the first-stage fluidized-bed hydrofluorinator off-gas (Fig. 4.2),

2. 1808-scfm HEPA filter system in the combined $U F_{4}$ feed preparation and $U F_{4}$ fluidized-bed fluorinator off-gas system (Fig. 4.2),

3. 68-scfm high-energy venturi scrubber-condenser in the $\mathrm{UO}_{3}$ reductor off-gas system (Fig. 4.1),

4. 15,000-scfm pulse jet bag filter in the combined fluorination area and decontamination area ventilation systems (Fig. 4.6), and

5. 4000-scfm HEPA filter system in the combined ash handling calciner and spray dryer off-gas systems (Fig. 4.4).

The installed and annual O\&M costs for the 128 -scfm high-energy venturi is estimated using the method listed in ref. 6 , which is based on information presented in ref. 5:

$128 \mathrm{scfm}$ with safety factor of $1.36=128 \times 530 / 492 \times 1.36=188 \mathrm{cfm}$ at $70^{\circ} \mathrm{F}$

Cost with a $35.3 \%$ escalation factor $=$

$(188 / 60,000)^{0.6} \times \$ 104,000 \times 1.353=\$ 4400$

Cost of demister at $\$ 0.65 / \mathrm{cfm}=188 \times 0.65=\$ 122$

Total $=\$ 4522($ Use $\$ 4500)$

Structure: Estimated $100 \mathrm{ft}^{2}$ at $\$ 22 / \mathrm{ft}^{2}=\$ 2200$

Total $=\$ 6700$

The annual O\&M cost is estimated according to the method used in ref. 6, p. 80 :

Power: $(188 / 60,000)^{0.6} \times \$ 41,600 \times 1.128=\$ 1500$

Water: $0.031 \times \$ 3390 \times 1.128=\$ 118$ 
Maintenance Labor: $0.031 \times \$ 1005 \times 0.60 \times 1.258 \times 1.05=\$ 25$

Material: $0.031 \times \$ 1005 \times 0.40 \times 1.145 \times 1.03=\$ 15$

Total annual $O \& M=\$ 1700$

The method used for estimating the installed and annual O\&M cost of the 1808-scfm HEPA filter system is the same as that used for Case 3:

$1808 \mathrm{scfm} \times 530 / 492 \times 1.36=2648 \mathrm{cfm}$ at $70^{\circ} \mathrm{F}$ (Use three 1000 -cfm HEPA filters)

Installed equipment cost: $(3000 / 16,000)^{1.16} \times \$ 62,000=\$ 22,700$

Structure: $(3000 / 16,000)^{1.6} \times \$ 3100=\$ 1700$

$$
\text { Total }=\$ 24,400
$$

Annual O\&M:

Maintenance: $0.03 \times \$ 24,400=\$ 732$

Power: $10 \mathrm{hp} \times \$ 40 / \mathrm{hp}$-yr x $0.85=\$ 340$

Filter Testing: twice per year, $\$ 30 / \mathrm{yr} \times 2=\$ 60$

Filter Replacement: every 2 years, $\$ 300 / 2=\$ 150$

$$
\text { Total }=\$ 1282(\text { Use } \$ 1300)
$$

The estimated installed and annual O\&M cost for the 68-scfm high-energy venturi is estimated as follows:

$68 \mathrm{scfm} \times 530 / 490 \times 1.36 \cong 100 \mathrm{cfm}$ at $70^{\prime \prime} \mathrm{F}$

Installed equipment cost: $(100 / 6000)^{10.6} \times \$ 104,000 \times 1.353=\$ 3029$

Cost of demister: $100 \mathrm{cfm} \times \$ 0.65 / \mathrm{cfm}=\$ 65$

Total $=\$ 3094($ Use $\$ 3100)$

Structure: $100 \mathrm{ft}^{2} \times \$ 22 / \mathrm{ft}^{2}=\$ 2200$

\section{Annual O\&M}

$$
\text { Total }=\$ 5300
$$

$$
(128 / 188)^{0.6} \times \$ 1700=\$ 1349(\text { Use } \$ 1400)
$$

The estimated installed and annual O\&M cost for the 15,000 -scfm pulse jet bag filter is estimated as follows:

$15,000 \mathrm{scfm} \times 530 / 492 \times 1.36=22,000 \mathrm{cfm}$ at $70^{\circ} \mathrm{F}$

Installed equipment cost:

$$
(22,000 / 60,000)^{0.6} \times \$ 204,000 \times 1.353 \times 1.1=\$ 166,000
$$

Structure: ref. 11 , p. 396

Assume: $7 \mathrm{cfm} / \mathrm{ft}^{2}$ filter area $=22,000 / 7=3142 \mathrm{ft}^{2}$ filter area

$360 \mathrm{ft}^{2}$ required at $\$ 22 / \mathrm{ft}^{2}=\$ 7900$

$$
\text { Total }=\$ 173,900(\text { Use } \$ 174,000)
$$

Annual O\&M cost; ref. 7

Equipment: $(22,000 / 52,300)^{0.6} \times \$ 15,750 \times 0.94=\$ 8800$

Structure: $0.05 \times \$ 7910=\$ 400$

Total annual $O \& M=\$ 9200$

The estimated installed and annual O\&M cost for the 4000-scfm HEPA filter system is estimated as follows: 
$4000 \mathrm{scfm} \times 530 / 492 \times 1.36=5860 \mathrm{cfm}$ at $70^{\prime \prime} \mathrm{F}$ (Use six 1000 -cfm filters)

Installed equipment cost: $(6000 / 16,000)^{11.6} \times \$ 62,000=\$ 34,400$

Structure: $140 \mathrm{ft}^{2} \times \$ 22 / \mathrm{ft}^{2}=\$ 3100$

Total $=\$ 37,500$

Annual O\&M

Maintenance: $0.03 \times \$ 37,500=\$ 1125$

Power: 15 hp x $\$ 40 /$ hp-yr x $0.85=\$ 510$

Filter Testing: twice per year, $\$ 30 \times 2=\$ 60$

Filter Replacement: every 2 years, $\$ 500 / 2=\$ 250$

Total $=\$ 1945($ Use $\$ 1900)$

The complete costs for Case 4 are as follows:

Direct Cost:

Installed equipment $=\$ 443,000$

Structure $=\$ 29,600$

Total $=\$ 472,600($ Use $\$ 473,000)$

Indirect Cost:

$\$ 473,000 \times 1.4=\$ 662,200($ Use $\$ 662,000)$

Capital Cost:

$\$ 473,000+\$ 662,000=\$ 1,135,000$

Annual Fixed Charge:

$\$ 1,135,000 \times 0.26=\$ 295,100($ Use $\$ 295,000)$

Annual O\&M cost:

$\$ 11,000($ Case 3$)+\$ 1700+\$ 1400+\$ 1300+\$ 9200+\$ 1900=\$ 26,500($ Use $\$ 27,000)$

Total Annual Cost:

$\$ 295,000+\$ 27,000=\$ 322,000$

Radioactive waste treatment Case 5a. Case 5a includes Case 4 and, in addition, the $120,000 \mathrm{scfm}$ of main process ventilation air is passed through pulse jet bag filters (Fig. 4.6).

The installed and annual $O \& M$ costs are estimated as follows:

The volumetric flow at $70^{\prime \prime} \mathrm{F}$ with a safety factor of $36 \%$ is:

$120,000 \times 530 / 492 \times 1.36=176,000 \mathrm{cfm}$

It is assumed that three $60,000-\mathrm{cfm}$ pulse jet bag filters will be installed outside the main process building in a self-contained housing and that, consequently, an additional structure cost is not required.

Installed equipment cost: $3 \times \$ 204,000 \times 1.353 \times 1.1=\$ 910,839$ (Use $\$ 911,000$ )

Annual O\&M cost:

$3 \times(60,000 / 52,300)^{0.61} \times \$ 15,730 \times 0.94=\$ 48,000$ 
The complete costs for Case 5a are as follows:

Direct Cost:

Installed equipment $=\$ 1,354,000$

Structure $=\$ 29,600$

Total $=\$ 1,383,600($ Use $\$ 1,384,000)$

Indirect Cost:

$\$ 1,384,000 \times 1.4=\$ 1,937,600($ Use $\$ 1,938,000)$

Capital Cost:

$\$ 1,384,000+\$ 1,938,000=\$ 3,322,000$

Annual Fixed Charge:

$\$ 3,322,000 \times 0.26=\$ 863,720$ (Use $\$ 864,000)$

Annual O\&M cost:

$\$ 22,500($ Case 4$)+\$ 48,000=\$ 70,500($ Use $\$ 71,000)$

Total Annual Cost:

$\$ 864,000+\$ 71,000=\$ 935,000$

Radioactive waste treatment Case 5h. Case 5b includes Case 5a plus a cement plant, which is included for incorporating the filter fines bed material (Fig. 4.4) in cement and drumming the product. The costs of shipping the drums offsite for storage or burial are not included.

The installed equipment cost is estimated based on information presented in ref. 6, p. 190, and using a field installation factor of 1.8. The installed cost of the equipment comprising the cement plant is estimated as follows:

Solids to be handled:

\begin{tabular}{lcc} 
& MT/year & Tons/year \\
Filter fines $\mathrm{CaF}_{2}$ & 67.5 & 74.3 \\
Bed material $\mathrm{CaF}_{2}$ & 21 & 23.1 \\
$\mathrm{CaF}_{2}$ & 165 & 181.5 \\
$\mathrm{Ca}(\mathrm{OH})_{2}$ & 33.5 & 36.9 \\
$\mathrm{KOH}$ & 107 & 117.7 \\
\cline { 2 - 2 } & 394.0 & 433.5
\end{tabular}

It is assumed that the cement plant operates the equivalent of 150 days per year.

433.5 tons $/$ year $\mathrm{x} 1$ year/ 150 days $=2.89$ (Use 3 tons $/$ day) 
It is assumed that the cemented solids have the following composition:

\begin{tabular}{lll} 
Cement & $45 \%$ & 9 tons/day \\
Solids & $15 \%$ & 3 tons/day \\
$\mathrm{H}_{2} \mathrm{O}$ & $40 \%$ & 8 tons/day \\
\cline { 2 - 2 } & & 20 tons/day
\end{tabular}

Installed Equipment Cost:

Pneumatic Cement Unloader:

$$
\$ 40,000 \times(9 / 50)^{10.6} \times 1.8=\$ 12,900
$$

Cement Storage Silo ( 75 tons):

$\$ 34,774 \times(75 / 350)^{1.6} \times 1.8=\$ 24,900$

Drum Dumper: Assumed $=\$ 6,000$

Gravimetric Feeder:

$\$ 6040 \times(75 / 350)^{0.6} \times 1.8=\$ 4,300$

Mixing Tank Rubber Lined:

$\$ 11,704 \times(75 / 350)^{0.6} \times 1.8=\$ 8,400$

Slurry Pump:

$\$ 4100 \times 2.4=\$ 9,800$

Total $=\$ 66,300$

Structure: Assume $100 \mathrm{ft}^{2}$ required

$100[(4.09 \times 1.3)+1.75+1.5+1.7+1.1] \times 1.06^{+}=\$ 14,400$

Annual cost for drums:

20 tons $/$ day $\times 150$ days $/$ year $\times 2000 \mathrm{lb} /$ ton $=6 \times 10^{\circ} \mathrm{lb} /$ year

Assume density of cemented solids $=100 \mathrm{lb} / \mathrm{ft}^{3}$

$\left(6 \times 10^{\mathrm{h}}\right) / 100=60,000 \mathrm{ft}^{3} /$ year

A 55-gal drum is equivalent to $7.5 \mathrm{ft}^{3}$

Assume: drums $90 \%$ filled $-7.5 \times 0.9=6.75 \mathrm{ft}^{3} /$ drum

$60,000 / 6.75=8900 \mathrm{drums} /$ year at $\$ 10 / \mathrm{drum}=\$ 89,000$

Allowance for Case 1 drums $=\$ 15,400$

Additional expense for Case $5 \mathrm{~b}$ drums $=\$ 73,600$

Annual cost for cement: Assume $\$ 35 /$ ton

9 tons/day $\times 150$ days/year $\times \$ 35 /$ ton $=\$ 47,250$ (Use $\$ 47,300$ )

The complete costs for Case $5 \mathrm{~b}$ are as follows:

Direct Cost:

Installed equipment $=\$ 1,450,000$ 


$$
\begin{aligned}
\text { Structure } & =\$ 44,000 \\
\text { Total } & =\$ 1,494,000
\end{aligned}
$$

Indirect Cost:

$\$ 1,494,000 \times 1.4=\$ 2,091,600$ (Use $\$ 2,092,000)$

\section{Capital Cost:}

$$
\$ 1,494,000+\$ 2,092,000=\$ 3,586,000
$$

Annual Fixed Charge:

$\$ 3,586,000 \times 0.26=\$ 932,360($ Use $\$ 932,000)$

Annual O\&M cost:

Case $5 \mathrm{a}=\$ 71,000$

Cement Plant Annual Fixed Charge x $0.40=\$ 16,600$

Drums $=\$ 73,600$

Cement $=\$ 47,300$

Total $=\$ 208,500($ Use $\$ 209,000)$

Total Annual Cost:

$\$ 932,000+\$ 209,000=\$ 1,141,000$

\subsection{References}

1. M. S. Peters and K. D. Timmerhaus, Plant Design and Economics for Chemical Engineers, 2nd ed., McGraw-Hill, New York, 1968.

2. K. M. Guthrie, "Capital Cost Estimating," Chem. Eng. (N.Y.) 76(6), 114-42 (Mar. 24, 1969).

3. K. M. Guthrie, Process Plant Estimating, Evaluation, and Control, Craftsman Book Co., Solano Beach, Calif., 1974.

4. C. J. Stairmand, "The Design and Performance of Modern Gas Cleaning Equipment," Inst. Fuel, London, Bull. 29, 181 (1956).

5. William Ellison, "Wet Scrubbers Popular for Air Cleaning," Power $115(2), 62$ (February 1971).

6. A. D. Ryon and R. E. Blanco, Correlation of Radioactive Waste Treatment Costs and the Environmental Impact of Waste Effluents in the Nuclear Fuel Cycle for Use in Establishing "As Low As Practicable" Guides - Appendix A. Preparation of Cost Estimates for Volume 1, Milling of Uranium Ores, ORNL/TM-4903, Vol. 2 (May 1975). 
7. J. D. McKenna, J. C. Mycock. and W. O. Lipscomb, "Performance and Cost Comparison Between Fabric Filters and Alternate Particulate Control Techniques," J. Air Pollut. Control Assoc. 24(12), 1147 (December 1974).

8. C. O. Kirby, General Engineering Division. ORNL, private communication, May 1973.

9. J. J. Smith, Inspection Engineering, ORNL, private communication, May 1973.

10. G. Johnstone, Plant and Equipment Maintenance Service, ORNL, private communication, May 1973.

11. Air and Gas Cleanup Equipment, 2nd ed.. Noyes Data Corp., Park Ridge, N. J., 1972. 
Table A-l. Summary of costs (dollars) for the model recycle uranium $\mathrm{UF}_{6}$ plant - radwaste treatment cases $2-56$

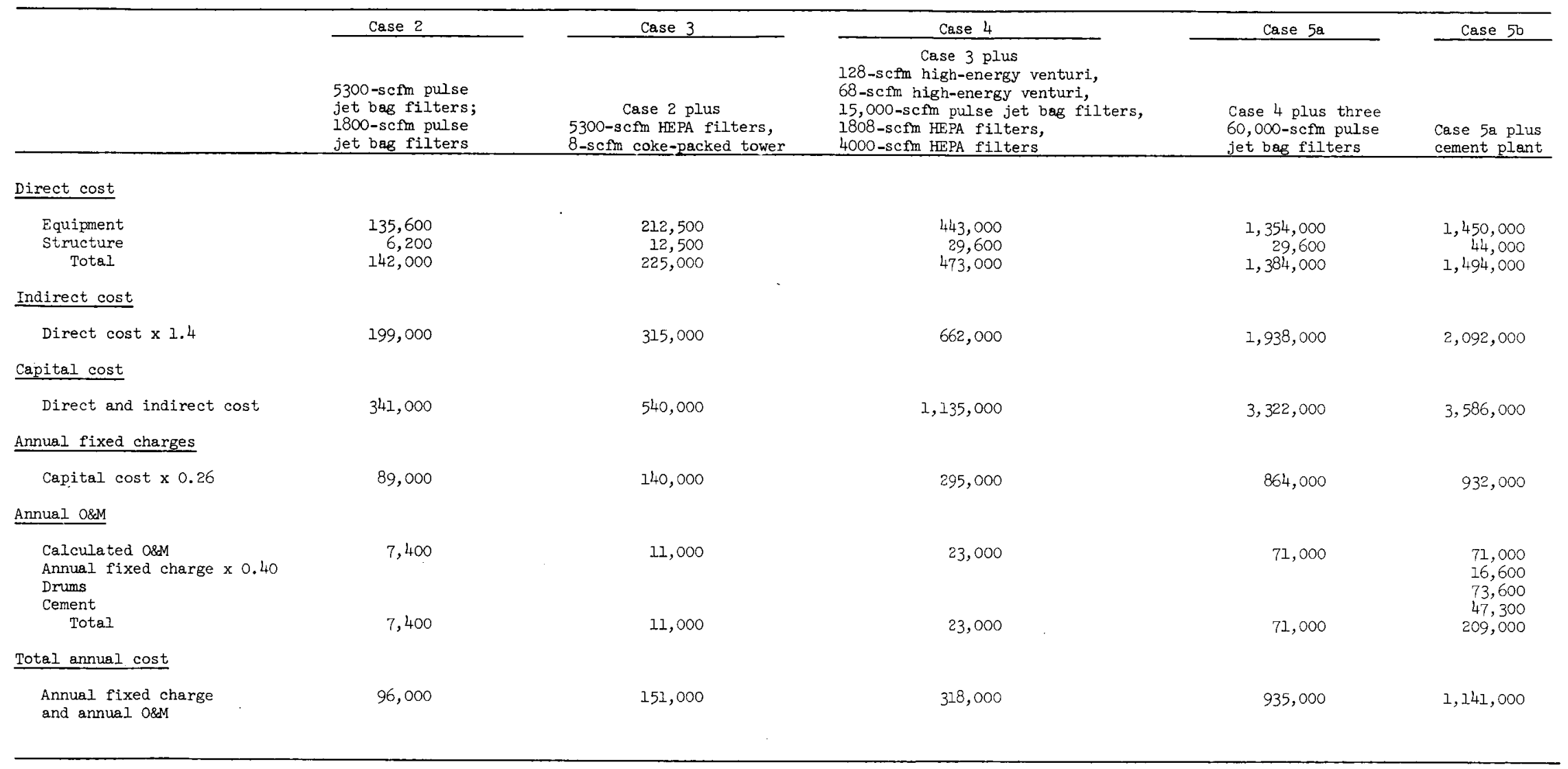


ORNL/NUREG/TM-37

Dist. Category UC-II

INTERNAL DISTRIBUTION

1. S. I. Auerbach

2. J. A. Auxier

3. S. E. Beall

4-53. R. E. Blanco

54. J. O. Blomeke

55. R. E. Brooksbank

56. K. B. Brown

57. W. D. Burch

58. C. A. Burchsted

59. C. F. Coleman

60. K. E. Cowser

61. F. I. CuIler

62. W. Davis, Jr.

63. G. G. Fee

64. M. I. Feldman

65. D. E. Ferguson

66-75. B. C. Finney

76. E. J. Frederick

77. W. Fulkerson

78. R. W. Glass

79. H. W. Godbee

80. H. E. Goeller

81. W. R. Grimes

82. W. S. Groenier

83. W. F. Harris

84. C. C. Haws

85. G. S. Hill

86. B. L. Houser

87. J. D. Jenkins

88. M. S. Judd

89. P. R. Kasten

90. S. V. Kaye

91. O. L. Keller

92. A. H. Kibbey

93. R. E. Leuze

94. K. H. Lin

95. A. I. Iotts

96. A. P. Malinauskas

97. J. P. McBride

98. W. C. McClain
99. J. D. McGaugh

100. L. E. McNeese

101. R. E. Moore

102. M. L. Myers

103. K. J. Notz

104. A. R. Olsen

105. J. R. Parrott

106. W. H. Pechin

107. H. Postma

108. C. O. Reiser

109 C. R. Richmond

110-114. J. W. Roddy

115. P. S. Rohwer

116. M. W. RosenthaI

117. C. T. Sanders

118. C. D. Scott

119. M. B. Sears

120. J. D. Sease

121. J. W. Snider

122. E. G. Struxness

123. J. E. Till

124. D. B. Trauger

125. W. E. Unger

126. P. R. Vanstrum

127. V. C. A. Vaughen

128. B. L. Vondra

129. J. W. Wachter

130. C. D. Watson

131. J. P. Witherspoon

132. R. G. Wymer

133. 0. O. Yarbro

134. E. L. Gaden, Jr. (consultant)

135. C. H. Ice (consultant)

136. R. B. Richards (consultant)

137-138. Central Research Iibrary

139-140. Document Reference Section

141-160. Laboratory Records

161. Laboratory Records-RC

162. ORNL Patent office 
EXTERITAL DISTRIBUTION

163. Research and Technical Support Division, ORO

164. J. Schacter, General Offices, UCND, Oak Ridge, Tenn.

165. G. W. Cunningham, Division of Waste Management, Production, and Reprocessing, Energy Research and Development Administration, Washington, D. C. 20545

166. W. R. Voight, Division of Uranium Resources and Enrichment, Energy Research and Development Administration, Washington, D. C. 20545

167. N. F. Barr, Division of Biomedical and Environmental Research, Energy Research and Development Administration, Washington, D. C. 20545

168. E. S. Beckjord, Energy Research and Development Administration, Washington, D. C. 20545

169. M. B. Biles, Division of Safety, Standards, and Compliance, Energy Research and Development Administration, Washington, D. C. 20545

170. R. D. Cooper, Division of Biomedical and Environmental Research, Energy Research and Development Administration, Washington, D. C. 20545

171. R. Franklin, Division of Biomedical and Environmental Research, Energy Research and Development Administration, Washington, D. C. 20545

172. J. H. Harley, Health and Safety Laboratory, Energy Research and Development Administration, 376 Hudson St., New York, N. Y. 10014

173. R. I. Hirsch, Division of Controlled Thermonuclear Research, Energy Research and Development Administration, Washington, D. C. 20545

174. R. H. Kennedy, Energy Research and Development Administration, Washington, D. C. 20545

175. J. I. Liverman, Office of the Assistant Administrator for Environment and Safety, Energy Research and Development Administration, Washington, D. C. 20545

176. W. H. McVey, Energy Research and Development Administration, Washington, D. C. 20545

177. D. R. Miller, Division of Physical Research, Energy Research and Development Administration, Washington, D. C. 20545

178. W. S. Osburn, Division of Biomedical and Environmental Research, Energy Research and Development Administration, Washington, D. C. 20545

179. G. B. Pleat, Division of Waste Management, Production, and Reprocessing, Energy Research and Development Administration, Washington, D. C. 20545

180. A. J. Pressesky, Division of Reactor Research and Development, Energy Research and Development Administration, Washington, D. C. 20545

181. H. E. Stelling, Energy Research and Development Administration, Washington, D. C. 20545 
182. J. Swinebroad, Division of Biomedical and Environmental Research, Energy Research and Development Administration, Washington, D. C. 20545

183. B. J. Mann, Thorium Fuel Cycle Study Project Officer, Environmental Protection Agency, P. O. Box 15027, Las Vegas, Nevada 89114

184. W. A. Mills, Criteria and Standards Division, Room 635C, Waterside Mal1, Environmental Protection Agency, Washington, D. C. 20460

185. J. L. Russell, Office of Radiation Programs, Environmental Protection Agency, 401 M St., SW, Washington, D. C. 20460

186. J. J. Swift, Technology and Assessments Branch, ORP, Environmental Protection Agency, Washington, D. C. 20460

187. J. H. Davis, Tennessee Valley Authority, Radiological Hygiene Branch, River Oaks Building, Muscle Shoals, Ala. 35660

188. I. Stratton, Assistant State Sanitary Engineer, State of IIlinois, Department of Public Health, $525 \mathrm{~W}$. Jefferson, Springfield, Ill. 62761

189. J. Matuszek, New York State Department of Health, Albany, N. Y. 12201

190. I. Burris, Jr., Argonne National Laboratory, 9700 South Cass Avenue, Argonne, III. 60439

191. C. E. Stevenson, Argonne National Laboratory, 9700 South Cass Avenue, Argonne, I11. 60439

192. C. Braun, Applied Science Department, Engineering Systems Analysis Division, Brookhaven National Laboratory, Upton, N. Y. 11973

193. J. M. Hendrie, Chairman, Dept. of Applied Science, Brookhaven National Laboratory, Upton, N. Y. 11973

194. D. M. Rohrer, Ios Alamos Scientific Laboratory, P. O. Box 1663, MS 518, Los A工amos, N. M. 87547

195. R. O. Pohl, Laboratory of Atomic and Solid State Physics, Cornell University, Ithaca, N. Y. 14853

196. G. G. Eichholz, Georgia Institute of Technology, School of Nuclear Engineering, Atlanta, Ga. 30332

197. B. Kahn, Environmental Resources Center, Georgia Institute of Technology, Atlanta, Ga. 30332

198. A. Schneider, Georgia Institute of Technology, School of Nuclear Engineering, Atlanta, Ga. 30332

199. M. Eisenbud, New York University Medical Center, Institute of Environmental Median, 550 1st Ave., New York, N. Y. 10016

200. A. M. Weinberg, Oak Ridge Associated Universities, Oak Ridge, Tenn. 37830

201. B. I. Spinrad, Radiation Center, Oregon State University, Corvallis, Oregon 97331

202. R. K. Weatherwax, Engineering Quadrangle, Rm C428, Princeton University, Princeton, N. J. 08540

203. G. H. Whipple, Chairman, School of Public Health, University of Michigan, Ann Arbor, Michigan 48104

204. B. I. Cohen, Department of Physics, University of Pittsburgh, Pittsburgh, Pa. 15261

205. K. G. Schiager, Department of Radiation Health, Graduate School of Public Health, University of Pittsburgh, Pittsburgh, Pa. 15261 
206. F. I. Parker, Socio-Engineering, Vanderbilt University, Nashville, Tenn. 37235

207. T. R. Lash, National Resources Defense Council, Inc., 664 Hamilton Avenue, Palo Alto, Calif. 94301

208. W. R. Ney, Executive Director, National Council on Radiation Protection and Measurements, 7910 Woodmont Avenue, Suite 1016, Bethesda, Md. 20014

209. I. S. Taylor, National Council on Radiation Protection and Measurements, 7910 Woodmont Avenue, Suite 1016, Bethesda, Ma. 20014

210. R. F. Foster, Pacific Northwest Laboratory, Battelle Memorial Institute, Box 999, Richland, Wash. 99352

211. D. A. Baker, Radiological Health Research, 3717 Bldg., 300 Area, Pacific Northwest Laboratories, P. O. Box 999, Richland, Wash. 99352

212. A. M. Platt, Pacific Northwest Laboratory, Battelle Memorial Institute, Box 999, Richland, Wash. 99352

213. K. J. Schneider, Pacific Northwest Laboratory, Battelle Memorial Institute, Box 999, Richland, Wash. 99352

214. J. M. Selby, Pacific Northwest Laboratory, Battelle Memorial Institute, Box 999, Richland, Wash. 99352

215. J. M. Taylor, Pacific Northwest Laboratory, Battelle Memorial Institute, Box 999, Richland, Wash. 99352

216. G. I. Simmons, Science Applications, Inc., 1200 Prospect St., LaJolla, Calif. 92037

217. J. A. Buckham, Allied General Nuclear Services, P. O. Box 847, Barnwell, S. C. 29812

218. A. D. Riley, Allied Chemical Company, P. O. Box 430, Metropolis, III. 62960

219. A. P. Roeh, Allied Chemical Corporation, Idaho Chemical Programs Operations Office, 550 2nd street, Idaho Falls, Idaho 83401

220. C. M. Slansky, Allied Chemical Corporation, Idaho Chemical Programs Operations Office, 550 2nd Street, Idaho Falls, Idaho 83401

221. H. Lawroski, Allied Chemical Corporation, Idaho Chemical Programs Operations Office, 550 2nd Street, Idaho Falls, Idaho 83401

222. R. Yates, Health Physicist, Allied Chemical Company, P. O. Box 430, Metropolis, III. 62960

223. A. L. Ayers, Allied General Nuclear Services, P. O. Box 847, Barnwell, S. C. 29812

224. R. I. Newman, Allied General Nuclear Services, P. O. Box 847, Barnwe11, S. C. 2S,182

225. A. K. Williams, Allied General Nuclear Services, P. O. Box 847 , Barnwe11, S. C. 29812

226. M. J. Szulinski, Atlantic Richfield Hanford Company, Federal Building, Richland, Wash. 99352

227. H. Gitterman, Director, Engineering and Research, Industrial Division, Burns and Roe, Inc., 283 Route 17 South, P. O. Box 663, Paramus, N. J. 07625 
228. S. Beard, Exxon Nuclear Company, Field Box 3965, San Francisco, Calif. 94119

229. R. C. Vogel, Exxon Nuclear Company, Inc., Research \& Technology Center, 2955 George Washington Way, Richland, Wash. 99352

230. E. J. Gornowski, Executive Vice-President, Exxon Research \& Engineering Co., P. O. Box 101, Florham Park, N. J. 07932

231. I. H. Brooks, General Atomic Company, P. 0. Box 81608, San Diego, Calif. 92138

232. D. Farney, General Atomic Company, P. O. Box 81608, San Diego, Calif. 92138

233. C. A. Heath, General Atomic Company, P. O. Box 81608, San Diego, Calif. 92138

234. S. Langer, General Atomic Company, P. O. Box 81608, San Diego, Calif. 92138

235. J. J. Shefcik, General Atomic Company, P. 0. Box 81608, San Diego, Calif. 92138

236. A. B. Carson, Fast Breeder Reactor Department, Energy Resources and Technology Division, General Electric Company, 175 Curtner Avenue, San Jose, Calif. 95100

237. J. F. Fletcher, Hanford Engineering Development Laboratory, P. O. Box 1970, Richland, Wash. 99352

238. M. T. Walling, Kerr-McGee Company, Oklahoma City, Okla.

239. W. H. Lewis, Vice-President, Nuclear Fuel Services, Inc., 6000 Executive Boulevard, Suite 600, Rockville, Md. 20852

240. W. A. Rodger, Nuclear Safety Associates, 5101 River Road, Bethesda, Md. 20016

241. J. S. Theilacker, Manager, Advanced Reactor Division Operations, Westinghouse Electric Corporation, Waltz Mill Site, P. O. Box 158, Madison, Pa. 15663

242. R. G. Post, Department of Nuclear Engineering, University of Arizona, Tucson, Ariz. 85721

243. Vinci Felix, Radian Corp., 8500 Shoal Creek Blvd., P. O. Box 9948, Austin, Texas 78766

244. Dade Moeller, 27 Wildwood Drive, Bedford, Mass. OI730

245. E. D. Harward, Environmental Project Manager, Atomic Industrial Forum, 7101 Wisconsin Ave., Washington, D. C. 20014

246. K. J. Davis, NUS Corp., 4 Research Place, Rockville, Md. 20850

247. J. Crow, CONAES Study, Professor of Genetics, University of Wisconsin, Madison, Wis. 53706

248. J. W. Landis, Sr. Vice-President, Stone \& Webster Engineering, P. O. Box 2352, Boston, Mass. 02107

249. M. Levenson, Nuclear Power Division, Electric Power Research Institute, 3412 Hillview Ave., Palo Alto, Calif. 94304

250. J. R. Clark, Nuclear Fuel Services, Inc., 6000 Executive Boulevard, Suite 600, Rockville, Md. 20852

251. J. McSweeny, Federal Energy Administration, Room 211, old Post Office Building, Washington, D. C. 20461

252. J. E. Fitzgerald, Criteria and Standards Branch (AW-460), Office of Radiation Program, U. S. Environmental Protection Agency, 401 M. Street, SW, Washington, D. C. 20460 
253. S. Golan, Scientific Development, Bechtel Power Corp., P. O. Box 3965, 50 Beale Street, San Francisco, California 94119

254. Andre J. Polliart, Director, Division of Nuclear Power and Reactors, IAFA, P. 0. Box 590, Karntner Ring 11, A-1011, Vienna, Austria

255. E. I. Ginzton, Chairman of the Board, Varian Associates, 611 Hansen Way, Palo Alto, Calif. 94303

256. H. Brooks, Technology and Public Policy, 217 Pierce Hall, Harvard University, Cambridge, Mass. 02138

257. J. H. Gibbons, Director, Environment Center, University of Tennessee, 330 South Stadium Bldg., Knoxville, Tenn. 37916

258. J. M. Hollander, Study Director, NRC CONAES, National Research Council, 2101 Constitution Ave., NW, Washington, D. C. 20418

259. D. Sive, Attorney at Law, Winer, Neuberger and Sive, 425 Park Avenue, New York, N. Y. 10022

260. J. C. Neess, Professor, Department of Zoology, Birge Hall, University of Wisconsin, Madison, WI 53706

26I. I. Iischer, Commonwealth Edison Co., One First National Plaza, Chicago, III. 60690

262. S. J. Lewand, Vice-President, Division Executive, Public Utilities Div., The Chase Manhattan Bank, N. A., One Chase Manhattan Plaza, New York, N. Y. 10015

263. R. R. Doell, Research Geophysicist, U. S. Geological Survey, 345 Middlefield Road, Menlo Park, Calif. 94025

264. H. S. Houthakker, Dept. of Economics, 218 littauer Center, Harvard University, Cambridge, Mass. 02138

265. R. H. Cannon, Jr., Chairman, Division of Engineering and Applied Science, California Institute of Technology, Pasadena, Calif. 91125

266. J. P. Holdren, Associate Professor, Energy and Resources Program, 112 T-5, University of California, Berkeley, Calif. 94720

267. K. E. Boulding, Professor of Economics, Institute of Behavioral Science, University of Colorado, Boulder, Colo. 80309

268. O. D. Duncan, Professor of Sociology, University of Arizona, Tucson, Ariz. 95721

269. D. Okrent, Professor, Energy and Kinetics, School of Engineering and Applied Science, University of California, Ios Angeles, Calif. 90024

270. Ferruccio Gera, C.N.E.N., Viale Regina, Margherita 125, 00198, Roma, Italy.

271. K. D. B. Johnson, U.K.A.E.R.E., Harwell, Didcot, Berkshire, England

272. R. G. Hart, Whiteshell Nuclear Research Establishment, Atomic Energy of Canada, Itd., Pinawa, Manitoba, ROE IIO, Canada

273. Franz R. Marcus, Nordic Iiaison Committee for Atomic Energy, Riso Huse 12, DK. 4000, Roskilde, Denmark

274. Johann Korkisch, Professor of Analytical Chemistry, Analysis of Nuclear Raw Materials, Institute of Analytical Chemistry, University of Vienna, A-1090, Vienna, Austria

275. Dr. Harmut Witte, Nukem GmbH, Postfach 110080, D6450, Hanau 11, Germany 
276. Franc Baumgartner, Professor fur Radiochemie, Universitat HeideIburg Kerforschungszentrum Karlsruhe, 75 Karlsruhe, Postfach 947, West Germany

277-559. Given distribution as shown in TID-4500 under Category UC-11 Environmental and Earth Sciences ( 75 copies - NIIS) 
NUCIEAR REGUTATORY COMMISSION

560. C. W. Bartlett, Fuel Cycle Research Branch, Office of Nuclear Regulatory Research, U. S. Nuclear Regulatory Commission, Washington, D. C. 20555

561. W. P. Bishop, Waste Management Branch, Division of Fuel Cycle and Material Safety, U. S. Nuclear Regulatory Comission, Washington, D. C. 20555

562. J. T. Collins, U. S. Nuclear Regulatory Comission, Washington, D. C. 20555

563. E. Conti, Environmental Standards Branch, Office of Standards Development, U. S. Nuclear Regulatory Commission, Washington, D. C. 20555

564-566. R. E. Cunningham, Division of Fuel Cycle and Material Safety, U. S. Nuclear Regulatory Commission, Washington, D. C. 20555

567. F. Empson, Fuel Fabrication and Reprocessing Branch No. 1, Division of Fuel Cycle and Material Safety, U. S. Nuclear Regulatory Commission, Washington, D. C. 20555

568. H. Lowenberg, Division of Fuel Cycle and Material Safety, U. S. Nuclear Regulatory Commission, Washington, D. C. 20555

569. P. Loysen, Project Manager, Fuel Reprocessing and Recycle Branch, Division of Fuel Cycle and Material Safety, U. S. Nuclear Regulatory Commission, Washington, D. C. 20555

570-572. J. B. Martin, Division of Fuel Cycle and Material Safety, U. S. Nuclear Regulatory Cormission, Washington, D. C. 20555

573-575. D. A. Nussbaumer, Division of Fuel Cycle and Material Safety, U. S. Nuclear Regulatory Commission, Washington, D. C. 20555

576-579. I. C. Rouse, Fuel Fabrication and Reprocessing Branch No. I, Division of Materials and Fuel Cycle Facility Iicensing, U. S. Nuclear Regulatory Commission, Washington, D. C. 20555

580-604. K. G. Steyer, Fuel Process Systems Standards Branch, Division of Engineering Standards, U. S. Nuclear Regulatory Commission, Washington, D. C. 20555 